\title{
FOREST REGULATION
}

\author{
ROTH
}



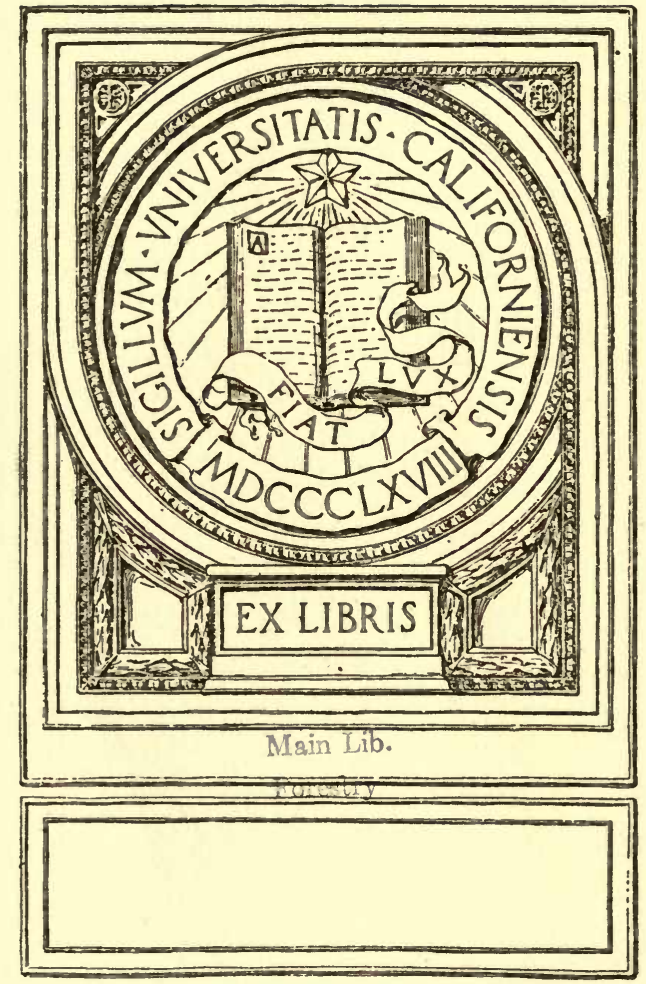






\title{
FOREST REGULATION
}

OR THE

\section{PREPARATION AND DEVELOPMENT OF FOREST WORKING PLANS}

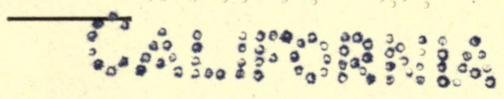 \\ VOLUME I \\ $\mathrm{OF}$ \\ Michigan Manual of Forestry
}

BY

FILIBERT ROTH

1914 


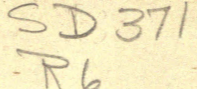

N.
$V .1$

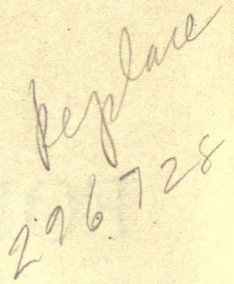

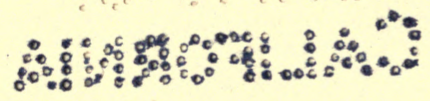

COPYRIGHT 1914

BY FILIBERT ROTH 
TO MY BOYS

THIS BOOK IS

DEDICATED

4.47380 



\section{TABLE OF CONTENTS.}

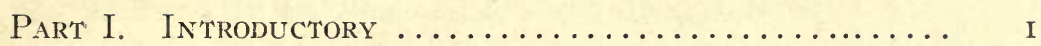

I. What Regulation tries to do.............. I

2. Typical German Forest Business............ 3

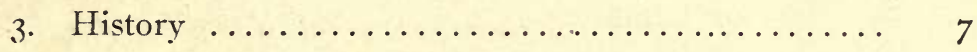

4. German Case of Regulation.............. II

Part IT. The Report on time, Property............ 24

A. The American Case....................... 24

B. The Field Work...................... $3^{\mathrm{I}}$

I. Examination of Property.............. 32

I. Preliminary Survey ................ 32

2. Detail Survey or Examination........... 34

a. Land Division ..................... 34

b. Value of Sub-division ............. 39

c. Description and Mapping ........... 43

I. Covering the Land ............ 43

2. Information and its Record ....... 45

3. Description Sheet ............. 47

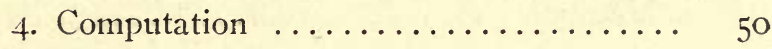

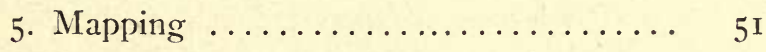

6. Accuracy of Work ............ 5 I

II. Special Studies in the Forest $\ldots \ldots \ldots \ldots \ldots \ldots \ldots, 5^{2}$

a. Volume Tables ................... $5^{2}$

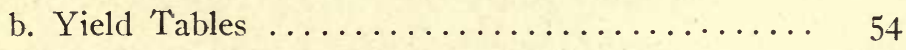

c. Forecast Tables ................. 57

d. Other Studies in Timber ............ 57

e. Conditions other than Timber $\ldots \ldots \ldots \ldots \ldots . \quad 5^{8}$ 
III. Information not of the Property $\ldots \ldots \ldots \ldots \ldots . \quad 59$

a. Exploitation, Methods, Cost ............ 60

b. Markets ........................ 60

c. Population and Business of District......... $6 \mathrm{I}$

d. Contracts and Leases ................ 6I

e. General Topography and I and of District..... 62

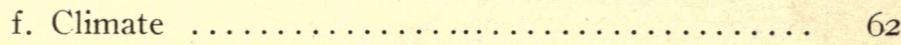

g. Present Organization $\ldots \ldots \ldots \ldots \ldots \ldots \ldots \ldots 64$

IV. List of Lands $\ldots \ldots \ldots \ldots \ldots \ldots \ldots \ldots \ldots, 64$

V. Detail Descriptions, Notes \& Maps........... $6_{5}$

C. Compilation of Information $\ldots \ldots \ldots \ldots \ldots \ldots \ldots \ldots, 66$

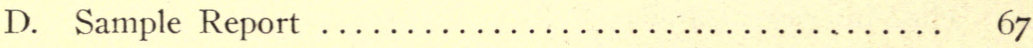

PART III. Plans $\ldots \ldots \ldots \ldots \ldots \ldots \ldots \ldots \ldots \ldots \ldots \ldots \ldots \ldots \ldots \ldots \ldots$

General Plans ........................... 8I

A. General Considerations $\ldots \ldots \ldots \ldots \ldots \ldots \ldots \ldots \ldots$ 8I

B. Object of Management $\ldots \ldots \ldots \ldots \ldots \ldots \ldots \ldots \ldots, 8_{3}$

C. Choice of Species $\ldots \ldots \ldots \ldots \ldots \ldots \ldots \ldots \ldots \ldots \ldots \ldots$

D. Methods of Silviculture $\ldots \ldots \ldots \ldots \ldots \ldots \ldots \ldots \ldots \ldots \ldots \ldots \ldots$

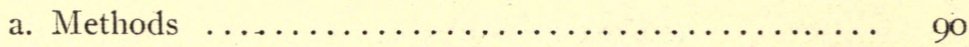

I. Selection Method $\ldots \ldots \ldots \ldots \ldots \ldots \ldots \ldots \ldots$ 90

2. Shelterwood Method $\ldots \ldots \ldots \ldots \ldots \ldots \ldots \ldots . \ldots 2$

3. Clear Cut with Natural Reproduction......... 93

4. Clear Cut with Artificial Reproduction........ 95

5. Coppice Method ................. 97

6. Standard Coppice $\ldots \ldots \ldots \ldots \ldots \ldots \ldots \ldots . \ldots \ldots$

b. What Method to Use $\ldots \ldots \ldots \ldots \ldots \ldots \ldots \ldots . . \ldots 9$

c. Illustrations from Different Forest Regions........ I00 


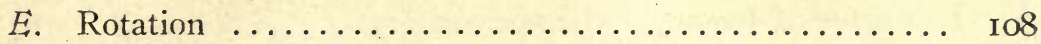

a. Technical Rotation .................. I0 8

b. Rotation for Largest Volume .............. II 2

c. Rotation for Largest Yearly Income .......... II2

d. Rotation for Highest Interest Rate on Soil ........ I I 3

e. Physical Rotation ..................... I I 5

f. Natural Rotation in Wild Woods ............. I I6

g. Choice of Rotation in U. S. . . . . . . II

F. Regulation of Cut in Amount and Location......... I I9

I. General Considerations ............... I I9

Age Classes and their Distribution; Working Section, Cutting Series; Regularity in the Wild Woods.

II. Methods of Regulating the Cut ........... I3I

A. General Considerations; Classification $\ldots \ldots \ldots \ldots \ldots$ I $3 \mathrm{I}$

B. Regulated or Normal Forest .............. I 34

C. Area Methods ..................... I39

I. Fixed Yearly Cut $\ldots \ldots \ldots \ldots \ldots \ldots \ldots \ldots \ldots \ldots$ I39

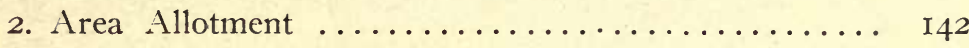

3. Limited Area Allotment or Judeich Method ...... 145

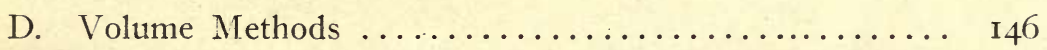

I. Volume Allotment ................ I47

2. Growing Stock Methods, Austrian and Hundeshagen. I5O

III. Application of Methods in U. S. . . . . . . I 59

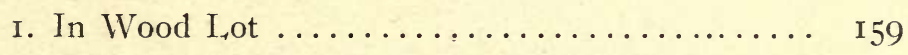

2. In Large Selection Forests ............ I60

3. In Southern Pinery ............... I6 3

4. In Lodge Pole Forests .............. I64

5. In Western Yellow Pine ............ I67

G. General Plan of Improvements ............. I7 I

$H$. Plan of Utilization ................. I75

I. General Plans of Protection ................ I80 
K. Estimates of Income and Expenses $\ldots \ldots \ldots \ldots \ldots \ldots, 182$

Detail Plans ......................... 183

I. Plan of Organization $\ldots \ldots \ldots \ldots \ldots \ldots \ldots$ I84

2. Plan of Protection ................. I 84

3. Plan of Improvements ............... ${ }_{18}$

4. Plan of Utilization ............... 186

5. Plans of Secondary Utilization .......... 189

6. Planting Plans .................... 190

7. Plans for Survey and Special Studies ....... I9I

Records or Book-keeping .................. 192

a. Record of Property ................ 193

b. Records of Work and Results ........... 195

Supervision and Revision ............... 199

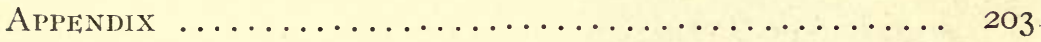

Treatment of the Subject of Regulation by Judeich,

Martin, Guttenberg, Stoetzer, and Weise....... 203 


\section{LITERATURE OF REGULATION}

Judeich, Forsteinrichtung (Forest Regulation), First edition, I87 I ; sixth, 1904. Generally recognized the greatest authority on Forest Regulation. Contains a complete list of literature, enumerates 229 works.

Guttenberg, Forstbetriebseinrichtung, I903.

Martin, Forsteinrichtung, 1906, and 1910.

Stoetzer, Forsteinrichtung, I908.

Weise, Leitfaden-der Errtragsregelung, I904.

Wagner, Grundlagen d. Räumlichen Ordnung im Walde, I9ı I.

Wagner, Der Blendersaumschlag und sein System, I9I2.

Schlich, Manual of Forestry, 1895, Vol. III, Forest Management.

Fernow, Economics of Forestry, I902; also History of Forestry, 1907.

Recknagel, Theory and Practice of Working Plans, I9I3.

See also Appendix. 



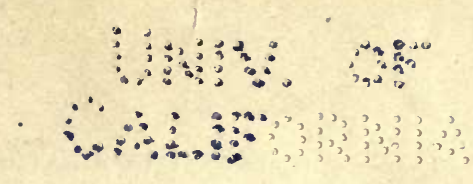

\section{PART I. INTRODUCTORY.}

\section{WHAT REGULATION TRIES TO DO.}

The task of Forest Regulation is :

To build up; Put in order, and Keep in order a forest business.

a) In the United States the task is to take a piece of Wild Woods and convert this gradually into a forest business which shall produce timber, as much and as good as the land and climate permit, and to have this timber in such a condition of age and arrangement that a crop may be cut each year, and thus an income secured in keeping with the investment.

'To accomplish this, Regulation not only orders in time and place, the work of Silviculture, the planting or reproduction of the stands of timber and their care, but it also plans an orderly harvest of these stands of timber, and plans the necessary improvements, division into suitable parts, necessary roads and other means required to enable satisfactory Protection and Utilization of the forest.

Regulation plans the work on the forest; Administration carries out the plans. But these two branches of Forest Management are never sharply separated.

b) Regulation depends on many conditions. It must consider the land and timber it has to work with to raise the crop, and it must consider market, transportation and labor which decide the value of the crop after it is raised. But Regulation is especially dependent upon Silviculture and their relation is interesting in this connection.

Silviculture studies the best methods of raising the stand of timber under the various conditions of soil, climate and species, and it applies these methods in its work. Thus Silviculture depends on natural (not man-made) conditions, and on natural laws and to this extent it must not be interfered with by Regulation and Administration. 


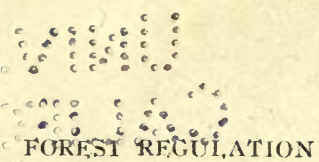

When Silviculture has indicated that a particular tract of land is suited to Spruce, and that Spruce will thrive if planted, thinned and cared for, according to a certain method, its share in Regulation is ended. Then it depends on Utilization and Valuation whether a certain method of planting is sufficiently economical to be planned for by Regulation, whether it is economical to use the method of planting with large transplants, whether it is advisable in this case to thin every ten years, and whether it is best to cut this timber at the age of 80 , or Io0 years. Regulation, weighing all conditions formulates the plan for Silviculture to follow, and do its best whether the decision is for seeding, planting, or natural reproduction, and whether it is the most effective, expeditious way of raising a stand of timber or not.

c) In our country the Forester starts with wild woods; often not even surveyed. In one locality he finds good market for every thing, in another no market at all; usually no division of the forests into convenient tracts, (fields or lots or compartments); no roads ; no help, no information regarding land or timber, save a few unreliable estimates of the "merchantable" stuff; no information as to how fast the timber grows, how old it must be before it reaches certain marketable sizes. The job is all new, and in many cases conditions do not warrant doing more than establishing ownership and giving the forest protection. Generally, however, the tendency is to overrate difficulties, and underrate possibilities. In the United States conditions change rapidly; what serves and seems sufficient today is no longer so tomorrow. Railways are building into every nook and corner of our country; the demand for timber in the United States is enormous and is still on the increase; the price of stumpage has advanced, in some cases $500 \%$ in less than 20 years; large areas of supplies have been entirely exhausted; there is practically no growth replacing our cut. The development of forestry in the United States cannot take the slow way it has followed in the Old World. The tree planted today in almost any part of the eastern half of the United States will bring as good a stumpage as it would in Germany or France by the time it is ready to cut ; the forester builds for the future, and this future is safely judged by the best conditions seen in parts of our country even now. It is also safe to judge this future by the conditions existing in the most advanced and most prosperous parts of Europe. 


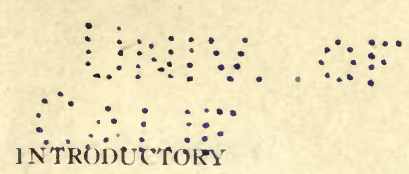

d) In Germany, say for the last roo years, Regulation did not usually start with wild woods, but it found an old business, well established, with areas marked, the forest divided, accessible by roads, with a system of protection, and with records giving experience to build upon. Practically everywhere the Market was established, and the necessity of the work was recognized. Modern Regulation merely established a better system just as modern farm management attempts to help agriculture by improving system.

e) But what is such a Forest Business as we wish to build up, and develop? The answer must come from the Old World, and hence the following brief description of a German Forest.

\section{A TYPICAL GERMAN FOREST BUSINESS.}

This "Revier" or Forest looked after by one Forester (Oberförster) is part of the State Forests of Württemberg, and may be described categorically about as follows:

Area : about 8000 acres ( 3205 hectares) ; nearly all in one body.

Staff of men or Organization: one "Oberförster," or Forester and six Rangers ("Forstwart").

Country: Hilly, and easy rolling, gravel and clay lands; old and well settled, prosperous.

Market: Can sell everything even faggot material, average price about $15 \mathrm{cts}$. per cu. ft. on stump; railway, trunkline, runs through one corner of the forest.

Labor: Plenty, but demands fair wages and steady work; numerous factories compete for this.

Roads: A complete network of roads, well located and surfaced with gravel, connects every tract or lot with the main lines and railway. These roads were built and are maintained by the forest itself.

Climate: Raw ; cold winters; cool wet summers, excellent for timber, and for agriculture; heavy wind storms due to proximity to the Alps.

Forest Protection: Good: the six Rangers patrol daily, all year round; the people of the district are not only compelled, but 
are glad to assist in prevention of fire. No rcal forest fire here in fifty years; probably not in a hundred.

Division of the Forest: Working Section I. Spruce forest, $85 \%$ of entire forest. Method of silviculture: Clear cut and plant, with 5 year transplants; ripe timber cut at age of $90-100$ years; all stands thinned about every Io years.

Working Section II. Beech forest 12\% total; Shelterwood method; rotation 120 years.

Working Section III: Mixed hardwoods $2 \%$ of total on overflow land; Selection Method, cut over every IO-I5 years. Alder grows here to a height of $100 \mathrm{ft}$.

Besides these three kinds of woods, there are a few small patches of hardwood Coppice. mostly Alder and Ash on wet spots, scattered through the forest, which also have their own plan.

Land Division: The entire forest is divided into fields or Lots (compartments) generally less than 40 acres in size and separated by cleared lines, or by roads. These Lots are all marked with stone monuments, and numbered.

Cutting Series: All over the entire forest, the Lots are grouped in twos or threes, and the lines around each of these groups is made double width or about $30 \mathrm{ft}$., so that the trees along these lines keep their limbs and form a solid protective border against wind, and also become more windfirm than they are inside the stands. These groups of two or three (rarely one) lots thus make little independent woods, separated from the surrounding woods, or their neightors, by wide lines, so that the timber on any one of these tracts can be cut without endangering the surrounding forest. These independent woods (Cutting Series), here in Spruce, are a necessity, for without them the forest would suffer great loss from windfall, if the older stands were opened $u p$ by accident or by cutting of timber.

Silviculture: The methods have been mentioned and the care here is of the best. A nursery on the property supplies all plant stock. Every stand is thinned at least once every ten years. Every acre of this forest is "man-raised," not one acre is original wildwoods.

Age Classes: Old, middle age and young timber occur here in such perfect regularity that there is a crop of Spruce, of Beech and 
of other hardwoods ready to cut every year, without fail. Having been under good management so long. there is now about the same area of Spruce I-20 years, 2I-40 years, etc., clear 11 p to Ioo year old stuff. But the 80-100 year old timber is not in one kody but is in a dozen or more different tracts, scattered over the forest; and this is also true of the young timber. In fact special care is had to prevent large tracts of timber all of one age, since this has been found dangerous particularly on account of windfalls and insects.

Cut of timber: Is yearly logged by contract, logging done "by hand"; done by small groups of men regularly employed on the forest; the material cut in thinnings is skidded to the road: where old stands are cut clear, the stems and cordwood are left on the land to be hauled away by the buyer. The timiter is cut in long lengths, commonly full length, like telephone poles, peeled, each piece marked and measurements noted on stick. The timber is sold in small and large lots, by auction sale. 'The thinnings pay well; for instance the thinning of a stand of Spruce 70 years old brought over $\$ 80.00$ per acre, after paying for labor. The total cut amounts to near a million cubic feet per year, and is of excellent shape and quality.

Income and Expenses: The expenses each year exceed \$3.00 per acre, or $\$ 25,000$ total. Over half is for logging, abont 30 cents per acre is for protection alone; a like amount is paid for local taxes, and about 20 cents for roads.

The gross income for years past has been over \$I 2.00 per acre, making a net income of about \$9.00-\$10.00 per acre and year or $\$ 70,000-\$ 80,000$ for the forest.

Working Plans: This forest was in good hands and had good care for centuries. A few old stands testify to the excellence in silviculture of the men working here over a hundred years ago. The present plan was first worked out about 1860 , has been revised every twenty years since. At each revision the Forester in charge of this work goes over every lot, examines and notes the condition of every stand. In making the plan he prepares a table, arranging the stands according to age, and picks out enough of these stands to make up the cut of the next 20 years : for the Spruce, then, about $I / 5$, for the Peech section about $I / 6$ of the total area. He also makes suggestions as to planting, thinning. logging, improvements, 
etc. The whole document, with maps, is submitted to the upper office, approved, copied, and one copy kept at the Forester's office to serve as directions for the next 20 years' work.

Here then is a forest business, where lands, for the most part inferior for agriculture, have been made into an enterprise paying a net rental of $\$ 9.00$ per acre and more, with an income value, at $3 \%$, therefore, of over $\$ 300$ per acre. The systematic work, the faithful following of a well conceived plan, has given to this forest certain advantages which the best of Silviculture alone, could not have accomplished. It has established order, it has. produced a regularity in the age of the different stands (in the age classes) which alone assures a regular yearly cut of timber. This same regularity also assures that the timber which is cut here is of the proper age, i. e., of the size desired. By a systematic, well planned cutting and prompt replanting, the stands of different age are properly mixed or distributed in the forest, and thus accidents prevented and the dangers reduced. Through the division into small lots and into small independent woods (Cutting Series) Silviculture is given a chance to get at a stand in any time and way required, without starting trouble which might spread over hundreds of acres.

Having good Silviculture and the regularity of age classes brought about through systematic cutting, the growth on this forest toth in volume and quality is about as large as Site and Species permit, since there are no old, overripe, and defective stands which would make little or no growth. Moreover, this same regularity assures this growth, and a regular yearly income on the smallest amount of timber capital upon which, under these conditions, this growth and income can be made.

Regulation, together with good Silviculture, has made here a splendid property, with a large income and has made it as safe an investment as a forest property can well become. A well planned and well built system of roads have made it possible to utilize everything to good advantage and easily doubled the stumpage value of every tree in the forest. Without this, the material cut in thinnings would be mostly valueless, and even the old stands would have to be cut in much larger bodies to pay in logging.

But, while the present good conditions of this forest are due, in a large measure, to Regulation or the orderly business-like treatment of this property, it must not be supposed that it was due to 
any particular Formula or Theory of Regulating the Cut, it was not even largely due to the Working Plan of 1860 and the revisions since, for this forest was in good condition, as all the old stands amply prove, as much as 80 and 100 years ago, and there had been good business here long before most of the formula and theories of our books had been published. It was the orderly work of capable men, faithfully persisted in, which built up this forest. On the other hand it is also true that it was Cotta's teaching of Regulation which gave to this forest (and hundreds of others) the proper division into Lots, and prepared the way for the necessary road system, and it was also Cotta's teaching which established the method of Regulating the Cut now followed here, converting an unsettled practice into a well-based, and recognized policy.

This, then, is the kind of forest business which the forester wishes to establish and develop in the $\mathrm{U}$. S. and for which there is the best of opportunity and the greatest of need. Several hundred million acres of wild woods await proper development, and a nation which uses over half of all the lumber cut in the world, is dependent on this development for its future supplies of timber.

\section{HISTORY.}

Forest Regulation, like Silviculture (and farming) is not new. To be sure, history tells but little about the arrangement of the work in the woods. But the excellent forests which were built up and of which at present some old stands date back 200 years to testify to good Silviculture, at least; then also the supply of good timber continuing for centuries, as recorded in the history of cities like Zurich, Frankfort, Nuremberg, Vienna, etc., and the timber husiness of the Rhine and other rivers, and lastly the scattered fragments of direct written record, all these clearly show that an orderly procedure in starting, caring for and in harvesting the crop developed early. In I359 the forest of the City of Ehrfurth was divided into seven parts, to be worked over in regular order. In I 422 the City Council of Zurich decided that the cut of the Sihlwald shall not exceed 20,000 pieces of timber per year, probably the oldest recorded volume regulation known. In i6zo a regular system of bookkeeping was started in this same forest and in 1696 the first 
regular written Working Plan was made for this property. The commission created for this purpose decided on a Volume to cut each year and this cut was continued up to 1835 , and has not been modified very much to the present time. Since a great deal of the forest about town and village were coppice woods where a piece is cut clear each year and thus an Area Regulation grows of itself, the regulation by setting a definite volume was probably the exception, and no doubt Schwappach is right when he states that Area Regulation was the rule from about the year I 300 to 1800 .

The Regulation or the preparation and development of Working Plans for the forest was a matter of slow growth, in keeping with the slow progress in all directions. Before railroads came into general use, i. e., before about 1840 , even the building of highways was restricted to a few trunk lines, and most of the country roads were almost useless for heavy hauling, and thus land-transportation of timber limited to very short hatl with little efficiency. As a result of these conditions, the woods about the villages and towns were largely overcut, and those a few miles away were hardly used at all, unless the timber was Spruce or Pine and could be driven on the stream.

The income from forests was very small, in many places the grazing and game being worth more than the timber. The net income in the State Forests of Württemberg well illustrates what these conditions were even after the year 1800:

NE'T INCOME PER

YEAR.

I 820 to '24

I 830 to ' 34

I 840 to ' 44

1850 to ' 54

I 860 to '64

I870 to '74
ACRE AND YEAR.

$\$ 0.55$

0.70

I. 79

I. 05

3.16

3.62

while today the average net income is more than $\$ 6.00$ per acre and year.

With net incomes generally less than 25 cents per acre and year, the great body of the German forests was not in a condition for better methods, either in Silviculture or in Regulation or business. With the rapid progress of the past century, the increase in popula- 
tion, the development socially and industrially, with highway, railway and canal building, the price of wood advanced, and even the remote woods could be made valuable. It no longer paid to wait for natural reproduction in bally treated, half-wild woods. Clear Cut and planting became the rule; the old woods roads, often half slide, half road, were abolished, well planned and well located roads were built and every lot was made accessible to good wagon and sleigh haul. These developments cost vast sums of money, and for years the net income was low accordingly, but now they are largely finished, and the income is going up rapidly and steadily in the State Forests of every State of the German Empire.

Modern Forest Regulation as taught in the text books of today is a development of the last I 50 years. As early as 1740 Jacobi taught Area Regulation with reduced areas; Frederick the Great ordered the division of the Pine woods of Prussia into Fixed Yearly Cuts and about the same time Beckman taught Volume Regulation. In 1795 the elder Hartig published his work on Volume Regulation, and in I8Ig introduced this method officially in the Prussian State Forests. In I 804 Cotta published his Area Allotment and laid the foundation to the Limited Allotment, or the "Judeich Method" (of Schlich) which, with slight variations, is today the official Method of the State Forests of nearly all German States. But to Cotta the Working Plan was more than merely a Regulation of the Cut in Volume or Area; he insisted that a proper division of the forest into Lots and into independent parts (Cutting Series) and then also a proper road building, the faithful following of the Working Plan and a regular revision of this Plan to adapt it to the ever changing conditions of the forest, were of far more importance than the mere estimate or calculation of the volume of timber which might be taken yearly from a forest in a particular period.

All through the past century numerous authors added to the literature of Regulation, and suggested various methods of Regulating the Cut. Stress was usually laid on the explanation of the perfectly regulated forest or "normal forest" as a model, and also on the numerous methods of Regulating the Cut, and this peculiar emphasis went so far that even at the present time there is a feeling abroad that the varions theories and formulas which have been invented (for the most part not used) of Regulating the Cut of 
timber, are all there is of importance to the subject of Forest Regulation. In recent times there has been, even in the textbooks, a return to Cotta's position. Judeich, really the surccessor as well as pupil of Cotta, follows the master; but the best exposition of the knowledge, appreciation and attitude of the well educated practice as well as that of the administrations of the German State Forests, is contained in Martin's Forest Regulation of Igro where 50\% more space is devoted to the directions concerning a proper division of the forest in plain and mountains, than is devoted to the methods of Regulating the Cut, all put together.

From the foregoing it is apparent that Forest Regulation is old. that good, well planned business existed in the forest as much as five centuries ago; at least in those forests where a regular profitable utilization was possible. (Zurich City Forest.) It also appears that Regulation shared in the modern development, but that the great factor in this progress lay in the development of market and transportation which gave to the forest the reason for doing and the funds to do with.

Today there is hardly an acre of state forest in the German Empire, and not an acre of village or city forest which has not a regular, well conceived, carefully prepared and closely scrutinized Working Plan, which must be followed by the forester, and which is revised at regular set intervals.

The same is true for all large private holdings and applies almost as much to France, Switzerland, Austria, the Netherlands. and Scandinavia and a large part of Russia as it does to Germany.

In the United States Forest Regulation, thanks to the progressive policies of the United States Forest Service, is well under way. Millions of acres of forest have been examined and the age, size, growth and behavior of most of our important species has been studied on many thousands of trees, and on thousands of stands of timber. Forest Regulation, next to Protection, forms the principal task on the great National Forests, where Working Plans are started and developed for an area of forest five times as large as that of all the forests of the German Empire, and are developing with real science and support and at a rate probably never equaled anywhere in the world. 


\section{THE GERMAN CASE OF REGULATION OR PREPAR- ATION OF A WORKING PLAN.}

To understand the task of preparing a Working Plan in a German forest, and also to appreciate the textbooks on Regulation it is necessary to keep in mind the conditions under which the work is ordinarily performed.

a) Practically all cases of Regulation in the State Forests (and these are chiefly considered in our books) are tasks of Revision. If a plan is due the following conditions hold:

The present plan is 20 years old. 'Twenty years ago every stand of timber was examined (except, of course those less than 20 years old). The age of the stand was even then known from a previous plan report; the condition was noted; if ripe or nearly so, or in bad condition and therefore in need of cutting, the timber was estimated; the care which the stand had received, i. e., whether properly thinned or not, was noted. In short, the stand was described, and this description is part of the plan which the Forester has in his office. This same plan indicates the stands which were cut during the last 20 years and the plan of planting tells what was to be put on the land; and the Forester's books show what was actually cut and planted, and when each job was finished.

The Plan report and maps indicate and enumerate the Lots into which the forest is divided, and the independent woods (Cutting Series) which have been established and also the order of cutting the timber and the direction in which this cut should progress on each of these cutting series.

The Plan of thinning indicates when the stands were to be thinned, and the book records show exactly when each stand received attention. The Plan report also enumerates and describes the roads, the boundaries, and the division lines and their condition; also the houses and other improvements on this property and in what condition they were 20 years ago, the improvements which were to be made; the book records show how much of this was actually done or left undone.

The Book of the office states how much timber was cut, its value and the cost of logging. It also tells of all important accidents, bad seasons, heavy storms, etc. 
The stands are practically all man-raised, most of them (over $90 \%$ ) even age and mostly pure stands, easily accessible and easily and conveniently looked over or examined. The thinnings have taken out the crooked, defective, etc., and the stuff is therefore quite uniform and sound.

Markets and means of transportation are long established, well known and hardly need consideration. This, then, is the property to be examined, described, and reported, for which a new forest map is made, and a Working Plan prepared.

'The Forester in charge of the task has all these data in his possession, he has a map guiding him from one lot to another; he knows beforehand what kind of timber he is to find on each lot. what its origin (planted or natural reproduction), its present age. its condition 20 years ago, whether it was cut and when, and what was planted on the land.

All this is so radically different from the task of the young American Forester, who goes out into the wild and unknown forest. And yet all these conditions affected the men who have written the textbooks, and have, therefore, made these textbooks assume conditions, and demand record, map and plan such as it is utterly impossible to supply under wild woods conditions. In fact these impossible demands have often made Regulation seem "impracticable" and even absurd, so that the young forester "lost heart" and refused even to try to do the possible and feasible.

It is evident, from the ahove, that Regulation becomes easier, simpler, and more accurate with each revision, and herein particularly lies the value of these repetitions.

The work is usually not done by the Forester in charge of the particular woods ${ }^{1}$ but, in all state forests, this task falls to a man from the office of Forest Regulation. This office tries to get around once every 20 years to all forests of the State, and it also makes an "Intermediate Revision", a sort of special inspection every Io years. The following tries to describe a case, following modern instructions.

\section{b) Premises: Plan to be made in rgr4.}

Forest, or "Revier": I0,c00 acres of State Forest, under present Working Plan since 1840 .

${ }^{1}$ Much controversy here; Prussian Instructions of I9I2 change this, and give this task to the local forester, as it should be. 
J evel, rolling and some foothill country, north of the Alps.

Three Working Sections, or Parts to plan for separately:

No. I. 6000 acres Spruce, Rotation Ioo years; Clear Cut and plant ;

No. II. 3000 acres Peech; Shelterwood; Rotation 120 years.

No..III. 1000 acres mixed forest, Beech, Spruce and Balsam; selection forest; period of return 15 years, Rotation about 150 years.

Cood market; roads; country well populated.

c) Plan to be made as the work of a General 20-year Revision. ("Haupt revision".)

I) In IGI 3 the Forester of this forest makes a report in which he states:

a) All important results; cut of timber, income and expenses; changes, improvements, plantations, accidents, etc., as recorded in his office during the last 20 years.

b) Recommendations, or suggestions regarding all important points in the Working Plan.

2) In I9I4 a technically trained forester of the Office of Forest Regulation is detailed to the task of making a new Working 'Plan for this forest. He is allowed such help as he may need. He has in his possession the present Working Plan, maps and the report of the Forester, furnishing all the information, as spoken of above. In most cases he has never been on this forest before.

d) Gathering the Information. This man goes over every stand in the forest, and describes the stand and its present conditions with the following distinctions:

I) Description of young and middle age, sound stands. This is quite simple, he merely needs to note:

a) How fully is the land covered by timber, i. e., degree of stocking.

b) Health and thrift of stand.

c) Care it has received; i. e., has it been properly thinned.

d) Age is noted, though of course he knows this from the records.

e) Suggestions as to what should be done.

This part of the work goes fast; it is chiefly a matter of travel, for the quality of the work depends on how much of each stand he has actually seen, and in these dense forests, in young stands, the distance of vision is not great. 
2) Ripe stands, i. e., those of the last age class, in Spruce, here 80-100 years old, he estimates by samples; in some cases he calipers and gets volume, quality and thus value by the Urich method; in other cases he merely states degree of stocking and uses the Yield tables to determine the amount of timber on the lot. $\mathrm{He}$ also notes condition of stand, and makes suggestions as to its treatment, i. e., whether to hurry about cutting, etc. In many cases he examines the stand for its growth, using borings and Schneider's formula.

3) The Description of Defective stands and stands where the growth is evidently poor, and also open stands, where wind, snow, etc., have opened and reduced the cover to 0.6 or below in density. Stands of this kind require much extra work, for they must not merely be seen but must be studied. He estimates the whole stand; dctermines density or degree of stocking; the age he has from his records; he tests the growth by borings, and finally he decides as to the best treatment. If the stand is very poor, and is making no growth of value, he suggests its removal during the next Io years, with suitable re-planting. It is particularly this class of stands which taxes the man's knowledge and draws on his experience.

4) The Description of the Selection forest. Here things are not so simple even if the forest is in good condition. The work needs to be done more in detail and it also requires more care and judgment. Old and young is mixed our the same acre, the picture is one of endless variation and with every step, the composition, and age classes (here really size-classes) change in their relative proportions.

Here each cut takes:

Ripe Stuff, i. e., trees over certain sizes; (harvest).

Inferior and defective stuff; (improvement cut).

Thinnings of good material and the cut also should stimulate or assist reproduction. Whether this has been done and done well, whether there was left enough of timber per acre to secure good growth. whether the age classes are well represented, and other related points need to be judged by the man who examines and describes these stands.

5) 'The description is made in a Manual or on loose sheets. each lot receiving its own sheet or double page with printed form, which reads about as follows: 


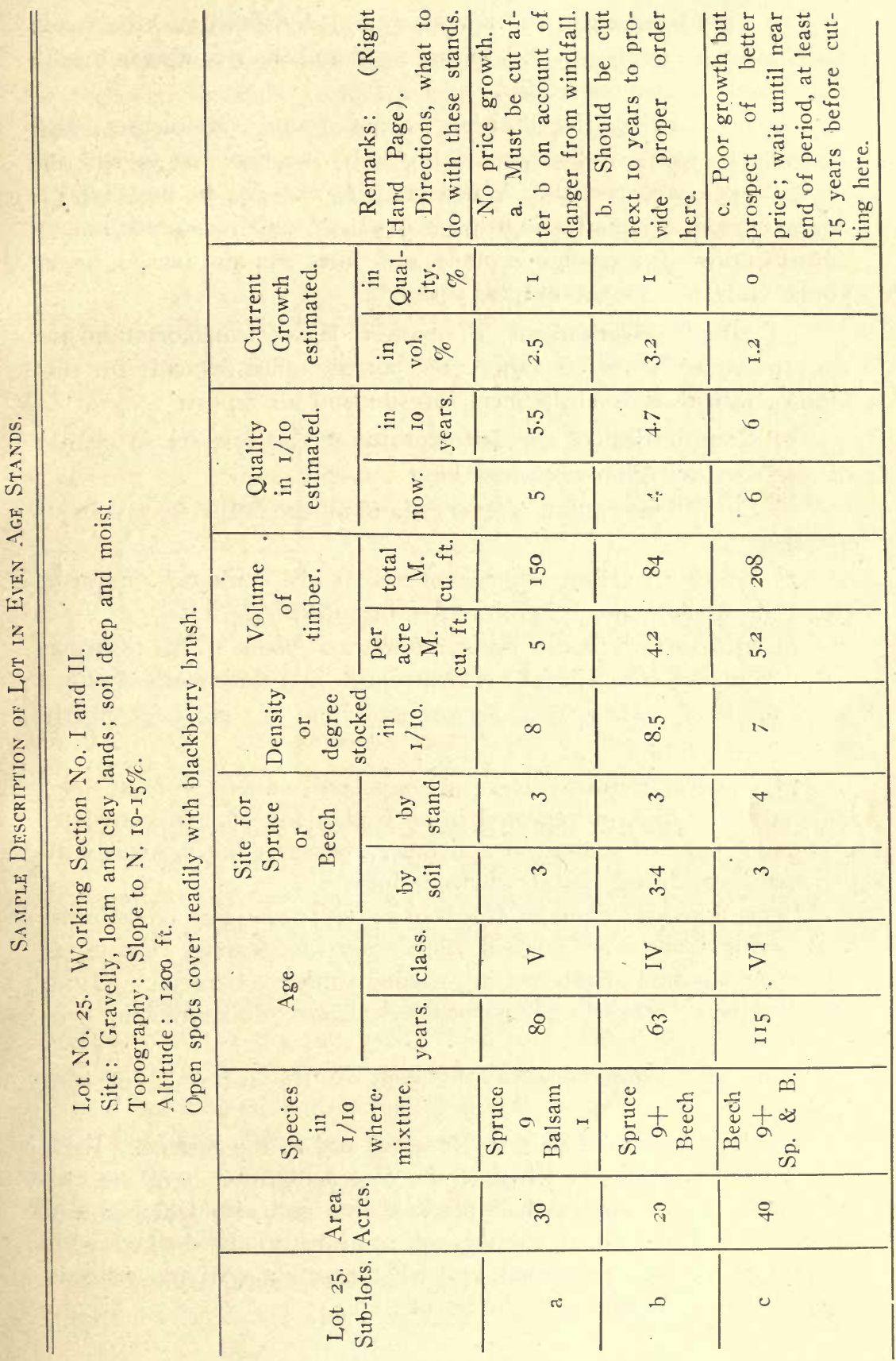


6) Improvements; the boundary and division lines, the roads and buildings, nursery, etc., are inspected and their condition briefly noted and suggestions added.

In rare cases, the division is not found satisfactory, and occasionally parts of the Loundary or division lines are re-run fo: verification or correction. Where radical changes in the division are indicated, the matter is first put on map with recommendations and if approved, a change is made, new lines run and blazed, or, in young stuff, at once cleared and opened.

7) Outside Conditions, of market, labor, transportation are not studied, ordinarily, by this man, but the office depends for this kind of information on the local forester and his report.

e) Compilation of the Information.- 'The forester in charge' of this Working Plan work now has:

I) Detail Description of every stand on the property, say about $25^{\circ}$. sheets.

2) Notes regarding improvements, roads, buildings, nursery, etc., and possibly outside affairs affecting utilization.

3) Information from former reports and plans. This information is compiled into a brief general report, and then worked into a Working Plan. These two, Report and Plan are not kept clearly separated as a rule.

I) General Report. Here are repeated numerous items, long known, and stated, or repeated in each plan for sake of completeness and for use of persons at a distance, therefore not familiar with this particular forest and its surroundings.

Items here are : name of forest or revier: area total ; area forest land, waste land, area wooded, and bare; topography, climate, at least special points of interest in growing timber; character of land, soil, drainage; market; transportation; labor; difficulties in protection, etc.

Then also improvements; divisions of the forests; this also heing shown on maps.

Special attention is paid to Rotation and to the Species. Each plan carefully considers whether the Species grown here are the best suited to the land and to market, etc., and also whether any particular Lot should or should not continue to be stocked with the timber now on the ground, and whether the age of 100 years is the right age at which to cut the Spruce, etc. 
Finally there is added a compilation of income and expenses taken from the records of the office, and usually an enumeration of the men or staff regularly employed. Of the maps the one representing the stands, their species and age (by colors) is renewed and brought up-to-date. Then there is worked out for each Working Section (except the Selection forest) :

2) Table of Age Classes; which takes on about the following form.

Working Section I, Spruce, Rotation ioo Years.

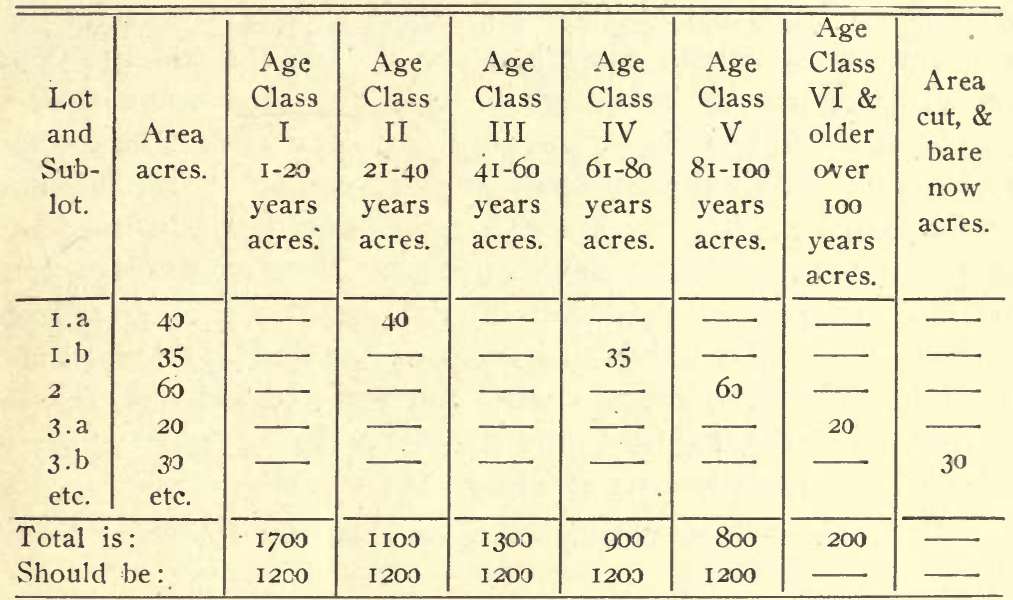

The addition of these tables presents the Age Class conditions, and tells the forester at a glance how much land is stocked with Spruce of the different ages and how far the age classes are irregular. Thus in the above case, age class I has too much by about 500 acres, etc.

3) Table of Sites, i. e., a table showing the quality of land on different parts of the property. This table takes about the same form as the table of age classes, the Sites, usually I-V, taking the place of age classes, and compiled directly from the detail description of the Lots. This important table tells how much good, medium and poor forest land there is on the property, the criterion here being the height of trees of given age, and still more the volume of timber on a fully stocked acre of a certain age.

4) Stand Table. This is an incomplete table; it brings together only the stands which are now ripe, and also all stands which 
are in poor condition and should be cut during the next 20 years. The information is first gathered from the table of Age Classes (see above) and then corrected by the original field descriptions. At this point the good sense and training of the forester are very much needed. 'The aim here in the Spruce Section is to cut only about 1200 acres in the next 20 years, to secure, gradually, a greater regularity in Age Classes, this being the normal area to cut in this Working Section, i. e., $6000 / 100 \times 20=1200$. Whether or not it is good policy here to cut the 1200 acres during the next 20 years is quite an important question and needs a careful consideration of the whole situation. Since both the $4^{\text {th }}$ and the $5^{\text {th }}$ Age Class

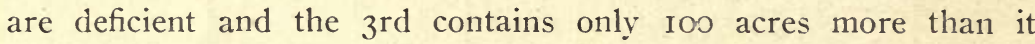
should, it would seem better to save a little during the first 20 , and probably even during the second 20 years period. After deciding on the total area, it is necessary to decide what stands to take and what stands to leave for another period. In cases where a considerable number of defective, injured stands make up a large portion of the older stands this choice is anything but simple, and many a good forester has chafed for years, because at the last Revision the plan required him to hold a lot of stuff which is diseased and dying in spite of all the care possible.

The stand table commonly takes on about the following form:

Working Section I, Spruce, Rotation 100 Years.

Stands SedeCted for Years I914-I933. (To be Revisfid in 1924.)

\begin{tabular}{|c|c|c|c|c|c|c|c|c|c|c|}
\hline \multirow{3}{*}{$\begin{array}{l}\text { Lot } \\
\text { and } \\
\text { Sub- } \\
\text { lot. }\end{array}$} & \multirow{3}{*}{$\begin{array}{l}\text { Area } \\
\text { acres. }\end{array}$} & \multirow{3}{*}{$\begin{array}{l}\text { Age } \\
\text { years. }\end{array}$} & \multicolumn{4}{|c|}{ Volume of Timber. } & \multirow{2}{*}{\multicolumn{2}{|c|}{$\begin{array}{c}\text { Total Volume } \\
\text { when it } \\
\text { will be cut }\end{array}$}} & \multirow{3}{*}{$\begin{array}{l}\text { How Volume } \\
\text { and } \\
\text { Growth were } \\
\text { determined. }\end{array}$} & \multirow{3}{*}{$\begin{array}{c}\text { Growth } \\
\text { in } \\
\text { Value } \\
\text { in } \\
\text { per } \\
\text { cent. }\end{array}$} \\
\hline & & & \multicolumn{2}{|c|}{$\begin{array}{c}\text { At } \\
\text { present }\end{array}$} & \multicolumn{2}{|c|}{$\begin{array}{l}\text { Growth } \\
\text { in } 10 \\
\text { years }\end{array}$} & & & & \\
\hline & & & $\begin{array}{l}\text { per } \\
\text { acre } \\
\text { M. }\end{array}$ & $\begin{array}{l}\text { total } \\
\text { cu. ft. }\end{array}$ & $\begin{array}{c}\text { per } \\
\text { acre } \\
\text { M. }\end{array}$ & $\begin{array}{l}\text { total } \\
\text { cu. ft. }\end{array}$ & $\begin{array}{l}\text { per } \\
\text { acre } \\
\text { M. }\end{array}$ & $\begin{array}{l}\text { total } \\
\text { cu. } \mathrm{ft} .\end{array}$ & & \\
\hline I. a & 40 & 105 & 7 & 280 & c.5 & 20 & 7.5 & 300 & $\begin{array}{c}\text { Vol. estimated, } \\
\text { growth } \\
\text { by boring. }\end{array}$ & 1.2 \\
\hline I.b & 30 & 93 & 6 & 180 & 0.8 & 24 & 6.8 & 204 & $\begin{array}{l}\text { Vol. by Yield } \\
\text { table. } \\
\text { Growth by } \\
\text { yield table. }\end{array}$ & 2.9 \\
\hline
\end{tabular}


Where the Age Classes and conditions generally are very irregular, as they sometimes are even in well managed forests, after insectcalamities, etc., the stand table takes on a different form. It is more comprehensive, takes in all the stands of the forest, or at least all over 40 years, in the case here considered. The following sample will illustrate this :

Are, Alitotment for Working Section No. I.

Spruce, Rotation ioj Years.

\begin{tabular}{|c|c|c|c|c|c|c|c|c|}
\hline $\begin{array}{l}\text { Lot } \\
\text { and } \\
\text { Sub- } \\
\text { lot. }\end{array}$ & $\begin{array}{l}\text { Area } \\
\text { acres. }\end{array}$ & $\begin{array}{r}\text { Age } \\
\text { years. }\end{array}$ & $\begin{array}{c}\text { Period } \\
\text { I } \\
\text { cut in } \\
\text { I9I } 4-33 \\
\text { acres. }\end{array}$ & $\begin{array}{c}\text { Period } \\
2 \\
\text { cut in } \\
\text { I934-53 } \\
\text { acres. }\end{array}$ & $\begin{array}{c}\text { Period } \\
3 \\
\text { cut in } \\
\text { I954-73 } \\
\text { acres. }\end{array}$ & $\begin{array}{c}\text { Period } \\
4 \\
\text { cut in } \\
\text { I974-93 } \\
\text { acres. }\end{array}$ & $\begin{array}{c}\text { Period } \\
5 \\
\text { cut in } \\
\text { I994- } \\
2013 \\
\text { acres. }\end{array}$ & Remarks. \\
\hline I. a & 40 & 35 & $\longrightarrow$ & $\longrightarrow$ & $\longrightarrow$ & 40 & $\longrightarrow$ & \\
\hline I.b & 80 & 68 & & 83 & & & - & Poor stand \\
\hline 2 & 60 & 52 & & $\longrightarrow$ & 60 & $\longrightarrow$ & $\longrightarrow$ & remove \\
\hline $3 \cdot a$ & 50 & I5. & - & . & & - & 50 & early. \\
\hline $3 . \mathrm{b}$ & 40 & 87 & 40 & - & - & $\longrightarrow$ & $\longrightarrow$ & \\
\hline
\end{tabular}

F.tc., etc., Etc.

This table resembles the Table of Age Classes, but is amply annotated with statements concerning the character of each stand and directions for its treatment. It thus presents the conditions of area and requirements of all the stands of the forest in a convenient form, and facilitates the selection of stands for the next 20 years, by indicating what may be expected here not only at the end of the next 20 years but for the next 60 and more years, in fact, in the above table for the entire Ioo years to come. There is no thought of making this allotment binding; it is merely to serve the purpose above stated, and this table is re-constructed every 20 years in keeping with the conditions which will then be found. When the stands for the next 20 years are finally selected, they are worked over once more and a Detail Plan of Cutting is prepared, which tabulates the stands to be taken during the first ro years. The following illustrates this table: 
5) Detail Cutting Plan for the years 1914-1923.

Working Section it, Beech, Rotation izo Years.

\begin{tabular}{c|c|c|c}
\hline $\begin{array}{c}\text { Lot } \\
\text { and } \\
\text { Sub-lot. }\end{array}$ & $\begin{array}{c}\text { Area } \\
\text { acres. }\end{array}$ & $\begin{array}{c}\text { Volume } \\
\text { estimated } \\
\text { M. cu. ft. }\end{array}$ & $\begin{array}{c}\text { Directions concerning the manner of cutting. } \\
\text { (Rules for cutting.) }\end{array}$ \\
\hline I7.c & 400 & 200 & $\begin{array}{c}\text { Take I/3 at first cut; hasten reproduction; } \\
\text { help if need be, artificially. }\end{array}$ \\
\hline $28 . b$ & 100 & 450 & $\begin{array}{l}\text { Finish clearing of old stuff, but leave few } \\
\text { trees for large timber. }\end{array}$ \\
\hline $28 . c$ & 80 & 375 & $\begin{array}{l}\text { Reproduce slowly, avoid damage from } \\
\text { storm; exposed position. }\end{array}$ \\
\hline
\end{tabular}

Etc., etc., etc.

This is a most important table; it tells the forester exactly what to do, where to cut, etc.

A table, practically like the foregoing is prepared for the Plan of Thinning to be done during the next Io years.

6) The Selection Forest receives its own Plan. This is usually a simple area table which directs that each year about I/I5 part of the area is cut over. Since the timber is not all cut at any one time there is need for setting some volume as the amount to take per acre. Since the "Return" here is every I 5 years, the cut should take about 15 years growth each time going over the forest. If an acre is estimated to produce $75 \mathrm{cu}$. $\mathrm{ft}$. per year, then the cut, each time, should take about $15 \times 75=1025 \mathrm{cu}$. ft. per acre of forest actually cut over. This plan appears about as follows:

Working Section No. III, Selection, Rotation about I50 y.; Diam. of ripe Beech-16"; Spruce-1 $4^{\prime \prime}$; Balsam--16".

Average Growth per acre estimated at $75 \mathrm{cu}$. ft. per acre.

Cut, therefore, takes about $1000 \mathrm{cu}$. ft. per acre, at each Return.

Diameter limit merely a criterion in thrifty good timber, i. e., no good Beech cut under $16^{\prime \prime}$ except in thinning. 
Cutting Plan for I914-I923.

\begin{tabular}{|c|c|c|c|c|c|}
\hline \multirow[t]{2}{*}{ Year. } & \multirow{2}{*}{$\begin{array}{l}\text { Cut lots } \\
\text { or parts } \\
\text { of lots. }\end{array}$} & \multirow{2}{*}{$\begin{array}{l}\text { Area } \\
\text { cut } \\
\text { acres. }\end{array}$} & \multicolumn{2}{|c|}{$\begin{array}{l}\text { Estimated } \\
\text { Volume } \\
\text { to cut }\end{array}$} & \multirow[t]{2}{*}{ Directions for cutting. } \\
\hline & & & $\begin{array}{l}\text { per acre } \\
\text { M. ft. c. }\end{array}$ & $\begin{array}{c}\text { total } \\
\text { M. ft. c. }\end{array}$ & \\
\hline 1914 & $\begin{array}{c}\text { lot } 1 \\
\text { part of } 2\end{array}$ & 70 & 0.8 & 56 & $\begin{array}{l}\text { This area has been cut } \\
\text { heavily last two returns, } \\
\text { growing stock below nor- } \\
\text { mal } \therefore \text { cut light. }\end{array}$ \\
\hline I9I 5 & $\begin{array}{l}\text { part lot } 2 \\
\text { part lot } 3\end{array}$ & 62 & 0.9 & 54 & $\begin{array}{l}\text { Growing stock slightly } \\
\text { below normal, and deficient } \\
\text { in large stuff. }\end{array}$ \\
\hline I916 & $\begin{array}{l}\text { part lot } 3 \\
\text { all lot } 4\end{array}$ & 69 & I.I & 74.8 & $\begin{array}{l}\text { Stocked about right, but } \\
\text { has too much large stuff. }\end{array}$ \\
\hline
\end{tabular}

For the entire forest (i. e., not for each Working Section separately) there is then prepared:

7) Plan of Planting, usually in the following form:

Planting Pian for. I9I4-I923.

\begin{tabular}{|c|c|c|c|c|c|c|c|}
\hline \multirow{3}{*}{$\begin{array}{c}\text { Lot } \\
\text { and } \\
\text { Sub-lot. }\end{array}$} & \multirow{3}{*}{ Area. } & \multirow{3}{*}{ What is to be done. } & \multicolumn{5}{|c|}{ Material to use. } \\
\hline & & & \multirow{2}{*}{ Seed. } & & Plants & 1003. & \\
\hline & & & & Spruce. & Balsam & Beech & Pine. \\
\hline $7 . a$ & 3. & Land, clear cut. & - & 70 & $\longrightarrow$ & - & - \\
\hline $19 . \mathrm{b}$ & 40 & $\begin{array}{l}\text { Correct fail spots with } \\
\text { good } 5 \text { year stock. }\end{array}$ & & 20 & 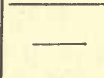 & $\therefore$ & \\
\hline $23 . a$ & 63 & $\begin{array}{l}\text { Assist nat. reproduction, } \\
\text { till and apply lime. }\end{array}$ & $\begin{array}{c}6000 \\
\text { Beech }\end{array}$ & & & 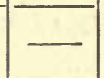 & 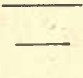 \\
\hline
\end{tabular}

Etc., etc., etc.

The plan for the nursery is added here, or a separate one is made.

8) Plan for Roads. This also is a forecast for the next to years (not the whole 20 years of the life of the Working Plan) and usually takes in roads, trails (footpaths) and also chites, slides, logging railways, so that there is hardly a limit here, and the plan might as well be called one of improvements.

The form is usually very simple, so that it does not replace detail map and specifications in cases like railroad, chute, etc., but merely keeps the tasks clearly before forester and inspector. 
Plan ol Roads and Other IMPRovements For I9I4-1923.

\begin{tabular}{|c|c|c|c|c|}
\hline \multirow[b]{2}{*}{ Location. } & \multirow[b]{2}{*}{ Description of Improvement. } & \multirow{2}{*}{$\begin{array}{l}\text { Length } \\
\text { or } \\
\text { area. }\end{array}$} & \multicolumn{2}{|c|}{ Cost. } \\
\hline & & & $\begin{array}{l}\text { per } \\
\text { unit } \\
\$\end{array}$ & $\begin{array}{c}\text { Total } \\
\$\end{array}$ \\
\hline $\begin{array}{c}\text { Connects } \\
\text { main road } \\
\text { in lot } 5 \text { with } \\
\text { lot } \text { i9 }\end{array}$ & $\begin{array}{l}\text { Woods road, to be dressed with } \\
\text { broken stone } 8 \mathrm{ft} \text {. wide. }\end{array}$ & $\mathrm{I}^{\mathrm{I} / 4}$ mile & I000 & 1225 \\
\hline $\begin{array}{l}\text { Lot } 12 \text { and } \\
13\end{array}$ & $\begin{array}{l}\text { Dry, wooden chute to be re- } \\
\text { paired. }\end{array}$ & $1 / 2$ mile & 400 & 200 \\
\hline $\begin{array}{c}\text { On main road } \\
\text { facing lot } \\
\text { I7 }\end{array}$ & $\begin{array}{l}\text { Clear for banking ground to } \\
\text { be used I9I5 and after that. }\end{array}$ & $1 / 2$ acre & So & 40. \\
\hline $\begin{array}{l}\text { Headquarters } \\
\text { to Ranger } \\
\text { Smith's }\end{array}$ & $\begin{array}{l}\text { Path to be repaired and dressed } \\
\text { with gravel in places. }\end{array}$ & I $3 / 4$ & 60 & 105 \\
\hline
\end{tabular}

Etc., etc., $\epsilon$ tc.

'To these several plans are added, normally:

9) Volume and Yield tables used on the forest, giving growth of tree and stand of the species raised here in recent time, also a table of value growth, and grades, either separate or added to the regular yield tables. Then also maps; land map; topographic detail map; stand map, this latter representing in colors the stands on different lots and indicating species and age class. Commonly also a map of forest division, simply giving lot, sublots, cutting series and working sections. 'These maps are all merely corrected copies of the old set of maps. Different States have different ways of presentation, and differ in the amount of. details added to these Plans. It is interesting to note that Saxony, and Württemberg, the two most advanced States as regards forestry, have probably the simplest forms, and the smallest amount of details.

Io) This body of documents is fastened together and forms the complete Working Plan. It is really made up of four more or less distinct parts :

a) Detail Report or Descriptions, kept separate.

b) General Report

$\left.\begin{array}{l}\text { c) General Plans } \\ \text { d) Detail Plans }\end{array}\right\}$ fastened together. 
This document is submitted to the local Forester, where it receives the most critical examination. It then goes to the office of Regulation, and, if no controversies come up, receives the approval of the highest official. It is copied, and one copy goes to the local Forester who then works according to this plan for the next 20 years. At the end of ro years there is a special inspection and, at least in some states (Bavaria) there is a new allotment of Stands, so as to give the forester a considerable number of stands to select from each year. At this revision new detail plans are made.

II The above outline suffices to show that the task of regulation as described in the textbook is feasible and perfectly practical; that each revision merely improves the plan; that this new plan does particularly two things:

a) It keeps the office (owner) informed of the exact condition of every stand on the property.

b) It adapts the work in the forest to these conditions. The above also shows, why the German textbook does not go into the matter of survey, timber estimating and description such as is needed in our wild woods, and why therefore these textbooks seem so far removed from the actual task of the American Forester. 


\section{PART II. THE REPORT ON THE PROPERTY.}

The preparation of a Forest Working Plan, as seen from the above, involves two quite distinct tasks:

The gathering of the Information and compiling this into a Report on the Property.

The making of the Plans for the Property.

In all cases the field work of gathering the necessary information is by far the greater task. In the United States with our wild woods conditions the plan itself must often be left tentative, and seems so crude that the whole Working Plan really appears as nothing more than a survey and description of the property or a report on the property, though, of course, this is not true and is merely a case of losing sight of the real object for which the information was collected. Better to appreciate the conditions in the United States which demand or lead to a Working Plan, and under which such a Plan is worked out, and also to see more clearly what such a Working Plan can and should contain and what it should accomplish, it may be well briefly to review the circumstances and the process of a typical American case. A tract of private property, rather than a State or National forest is chosen, because these latter forms of ownership involve a large organization where the making of a Working Plan, now, is merely one more task in the great routine of work.

\section{A. THE AMERICAN CASE.}

I) The assumption here is that a man in New York owns forest lands in Northern Michigan; that he is not, at present, in the business of lumbering, and that he wishes to know more about the property, with the possibility of converting this property into a regular forest business. 
When buying this land it was cruised in the ordinary way and he has, therefore, about the following information:

Area : 30,000 acres, all surveyed land (United States Survey) practically solid; in two 'Townships.

Forest and Lands: about 25\% originally pine on sandy lands, now cut and the land burned over. About $60 \%$ uncut hardwood and Hemlock on loam and clay lands with about $6 \mathrm{M}$. ft. merchantable timber. About r 5\% of 'Tamarack and Cedar Swamps, estimated to average $3 \mathrm{M}$. $\mathrm{ft}$.

His local representative has informed him that the saw fly is destroying the Tamarack, and that the fires of 1908 injured part of the hardwood forest; exact figures lacking.

His estimates are by 40 -acre tracts and usually include a few notes concerning land and topography. The property cost him $\$ 45^{\circ}, 000$ and is assessed at this figure. His taxes are $\$$ I 5 on every $\$ 1000$ worth of property or $\$ 6750$ total ; his expenses for representative, a local lawyer, for occasional cruising to watch for trespass, costs another $\$ 250$ per year.

2) The owner sends for a Forester; and after a brief interview he decides that he will pay the Forester $\$ 600$ for a preliminary report on the tract (i. e., two cents per acre). The owner prefers a brief preliminary report because he is not certain what he should do with the property, and it is the chief function, therefore, of this preliminary report to state truthfully and conservatively those facts which the owner should have in order to judge, intelligently, as to the best policy to pursue.

The Forester now goes to the locality, 11sually with letters and maps and a list of lands making up the property, commonly as list and also in form of township plats. His work will arrange itself as follows :

a) Visit to local representative. Here he gets names of men who can be helpful, chiefly local cruisers, persons to see and to stop with while going over the tract, names of county and town officials, names of timber people, loggers, sawmill men and buyers. In many cases he may need county map and town plats, 11sually obtainable at the courthouse.

b) Examination of the tract. For the purpose in hand, this is a hasty survey, covering the 30,000 acres in about three weeks. 
He needs a local man familiar with the tract, and able to take him at least to a fair number of Section corners without special delay.

Aside from a number of samples, to steady his judgment, it is not a detail estimate or cruise, but an orderly covering of the land to ascertain :

Character of land, topography and soil.

Character of forest; its present condition on every section; proportion of swamp, hardwoods and pine lands.

In such a cruise it is enough to know, at any one time, that it is good hardwood forest, and it is not necessary to stop and estimate the amount of timber by species, etc. It is well to verify a few estimates of the cruise made for the owner at time of purchase. Matters of reproduction, growth, and also cases of burns are noted, but not studied in detail.

c) Study of General Conditions. This is a matter of canvass as well as visit. Here the Forester learns about:

Roads and streams which may be useful to the enterprise; distances to railway, to sawmill.

Market for the different kinds of stuff now upon the land; chance to sell on stump, in log delivered, value of lumber, poles, ties, etc.

Chances to get labor, wages, etc., to get logging done by contract, and usual prices; to get stuff manufactured.

Safety of property from fire and trespass and possibilities to make it more safe.

Agricultural and other development of the district.

Notes on climate, days of sleigh haul, usual depth of snow, matters of frost (agriculture); regular dry spells, and also recurrence of dry seasons. A great deal of valuable matter is gathered incidentally. From the local representative and still more from local people the attitude of the people towards such a large property should be ascertained.

This outside study should take atout Io days.

d) Compilation of this information into a Report. This report must be very brief, and even then it should have the most essential points separated and categorically stated on one page. 
The Report should cover at least the following points:

Area and Location of property with special reference to Railway, town, mill, settlement and also with regard to distant, large market.

Transportation: for timber material, present rates to important points.

Business: development of district, lumbering, agriculture, here especially a reasonable outlook.

Land: its topography, soil, drainage; value for farming; climate and crops.

Timber: merchantable timber. If old cruise appears satisfactory compilation from this; condition of timber, present stumpage value and outlook; all on a brief, three or four line table.

Growth: If no net growth here, this should be stated. Price growth, i. e., growth due to increase in market price for each kind, for recent years.

Forest: Age conditions, Reproduction, young and middle age (by sizes); defective stuff.

Improvements on the property: roads, etc.

Exploitation: Chances for labor, contract work in logging and milling; usual methods. Climate and exploitation, snow haul, depth of snow.

Protection: Fire and trespass, also loss from sawfly, in this case and other troubles; dry spells, dry years, large fires in district.

Property and Forestry: Location, size, form, whether land and climate are suited to forestry ; advantages of market, and transportation, probable future of district.

Possible Plan: Necessity to decide definitely on holding the land; general plan to cut over, protect, improve, possible income and expense; development if a plan is followed; comparison to European properties of same character of soil and climate.

A State Map and County Map should accompany this report to show general location, especially lines of transportation and market.

A copy of the original town plats showing streams, swamps, etc. as per old.survey. On this may well be indicated cut-over lands, and swamps by colored crayon and also such roads as now exist. 
3) At a second interview of owner and forester, the important points of the above Report are discussed. If report and conditions prove satisfactory the owner decides to have a regular Working Plan prepared at an expense of not to exceed 25 cents per acre, or $\$ 7500$ total.

The Forester now repeats his work, but does everything in detail, so that instead of merely sampling the tract along the section lines, he goes over every 40-acre tract at least twice, and, where needed, he makes side-trips, so that he sees practically every acre of land on the property. 'This detail study also locates every corner, and re-establishes all lines.

In addition, the Forester makes a number of detail studies of growth, of the few important species.

With regard to outside condition, he not only learns about the chances of getting logging, etc., done and the general price, but he gets the names of men ready to contract and the prices at which they offer to work.

a. The Survey and Inventory by 40 -acre lots is made on regular printed forms, one sheet to each 40 ; and states:

The kinds or species of timber, and the proportion of these on the 40 -acre tract.

Ige or sizes, represented.

Amount of merchantable timber; above 12 or $\mathrm{I}_{4}$ inches diameter breast high; usually by kinds.

Density of timber; or how fully is the land covered.

Condition of timber; shape, size, defect, of both merchantable and non-merchantable stuff.

Young stuff; reproduction, sapling and pole stuff.

Land; topography, surface, soil, drainage.

Accidental Conditions; burns, windfall, bare land.

All this information must be called for in such form that it can readily be taken down in the field, easily seen on the sheet, easily taken off the sheet for compilation.

On this property there would be about $75^{\circ}$ separate sheets or descriptions and it would be useless for anyone to try to learn about this property without compiling this mass into one or more general statements and tables, and thus preparing a General Report. For 
this reason, the very form on which the field data are noted, needs careful consideration.

b. When finished, the Forester has:

I. 750 separate sheets of field notes.

2. About 50 Maps, detail, made in the field.

3. Many pages of figures collected to learn about the growth of timber, both as to the individual tree and the stand of trees.

4. Also pages of figures for Volume tables.

5. Many pages of notes concerning outside affairs.

The field notes should be copied; the growth figures and volume tables compiled and made into tables and diagrams. Then this mass of Detail information should be compiled into a General Report.

This General Report should be brief, it should resemble the first or former report, and it may not have a great deal of additional material. But it differs from the first report in the most essential point: It is based on actual detail knowledge.

c. Based upon this Report, detail and general, the forester prepares a Working Plan.

This Plan preferably falls under two heads, the

General Plan which outlines what is to be done with the property; usually for years ahead; and

Detailed Plans which tell what is to be done during the coming year; exactly where to cut, to build roads, etc.

The General Plan can and should always cover:

I. What is to be the policy of the owner: Hold the lands, gradually convert it into forest business, but not require more than $\mathrm{X} \%$ of stumpage receipts per year to be put back on the property, etc.

2. Timber Cutting: Whether to hold, or begin at once; sell stumpage or log per contract; about how much to cut over per year, etc.

3. Silviculture: If cut over by logging the large stuff only, then to what diameter to cut the different kinds, how closely to cut it over, i. e., how much should always be left on the land; how should the stuff be marked where there is no young growth, and how, on tracts with much young growth, etc. Here also: should, if necessary, a little money be spent to get rid of defective stuff and 
to get rid of tops. Also, should a replanting be done, and if so, with what kinds and should the stock be raised in a nursery on the property.

4. The best ways of protecting the property; what authority should the forester have to hire extra help in danger season; method of paying help; improvements, especially telephone, cabins to shelter the men; fire lines on the sand lands, etc.

5. What help is needed, how many regular men should be employed, what their salary and duties.

6. How much money should be allowed for the first five years, regardless of incomes from timber, and what should be the maximum to be allowed.

7. Some estimates of income and expenses.

8. What records or books should be kept and what reports made, and who should inspect the property to see that the plans are actually carried out.

d. Detail Plans. These cover especially:

I. Plan of Cutting the Timber; the areas to take the coming year, perhaps also the following: How it is to he logged, by whom and under what conditions of scaling, delivery, price, etc. Here also bark peeling, cordwood cutting, etc.

2. Silviculture; particularly the way of marking the timber, giving as detailed directions as possible. Then, also, brush disposal, removal of tops and defective stuff (this part of Cutting Plan). Plan for nursery and reforestation for the next few years, stating definitely how large a nursery, what kinds to raise, what forties to plant up, etc.

3. Plan of protection, to outline in all necessary detail exactly what to do, whom to call for help. how to report, etc.

4. Plan of Improvements, i. e., exactly what houses, barns, camps, roads, telephone lines to build the first year, and about what kinds and at what cost.

5. Plan of Organization and Funds; i. e., name and number of men to employ, how much extra help, when, at what pay; how much money to devote to each line of work.

To these Reports and Plans are added copies of all maps, here particularly three kinds : 
I. Land Map, showing area, direction of lines and length, etc.

2. 'Topographic Map showing improvements.

3. 'Timber or Stand Map showing in colors at least the three types of woods, pine, hardwood and swamp, as they occur on the forest.

e. Third Conference; the Working Plan is now submitted. By rights, the owner should have the work inspected, sampled and verified. If found satisfactory, it is received and paid for.

This now ends the task, and the owner is free to use these documents as he sees fit. If he does wish to go into forestry, however, he will find right at the outset, that a good forest Working Plan is nearly useless in the hands of an untrained man. Such a man can use the maps and the estimates and can have the timber cut and the forest cut over in the old, usually destructive way, but to use a Working Plan and build up a forest business requires a forester.

But even if the owner does not go into forestry, he will find, in most cases, that the expenditure (in our case $\$ 8100$ for both reports) is well warranted on a property worth $\$ 450,000$, just to know what the property really is, a thing which no ordinary cruiser report ever enables him to do. The cruiser report tells of logs and land (not always the latter) and leaves the forest, or the real property undetermined.

\section{B. THE FIELD WORK.}

'The gathering of the Information necessary as basis of a Working Plan and here summed $u p$ as the Field Work, usually involves three quite distinct parts:

a) The Examination of the property, land timber and improvements.

b) Special Studies, mostly studies of Growth and Behavior of the most important kinds of timber on the property.

c) Study of Outside Conditions, such as Market, Means of transportation, Chance for labor, Matters of taxation, etc. 


\section{EXAMINATION OF THE PROPERTY.}

In the United States the examination of larger forest properties usually starts with rather scant information. Even where the land has been honestly subdivided, the maps are inadequate, the information such as the course of streams, etc., is restricted to points on the section lines and all information with regard to the interior is estimated, often merely assumption. Topography, soil, stand of timber are practically unknown. In unsurveyed or only partly surveyed districts these difficulties are materially increased. And yet it may be desirable, even necessary to begin some kind of definite administration at once. Whether this leads to real forestry or merely to exploitation does not affect the case materially; at least a reasonable amount of information must be gathered, to enable the owner to come to some decision, and to make it possible to do business.

In such cases it is not feasible, or even desirable, to wait for a detailed examination. For even the satisfactory planning of this detailed examination itself requires considerable information with regard to survey, topography and general character of the forest. For these reasons the examination of large forest properties in the United States generally involves two distinct steps, the Preliminary Survey, and the Detail Survey, though the line between these two is not clearly defined.

\section{The Preliminary Survey.}

A kind of exploration work, justifies itself by gathering rapidly and cheaply, enough information to decide on a policy and future treatment of the property, or to enable the beginning of a Forest Administration. 'Thus the preliminary surveys of some of the National Forests, made by the United States Geological Survey covered several hundred thousand acres of unsurveyed country in a single summer. It seemed sufficient to learn the general topography, the streams and their valleys, the amount or proportion of forest, brush, burns, and waste lands in each valley; the soil and drainage, altitude, and changes of woods with this; the accessibility, and a few points regarding the use thus far made of these areas. 
In surveyed districts, these preliminary surveys usually sampled every section. In other cases such preliminary surveys establish systems of base lines or "control lines" from which caliper crews work out in both directions and cover the country in a regular order, and actually measure the timber on a certain per cent of the total property, and map and describe the soil topography, forest types, etc. Generally these preliminary surveys cost less than 3 cents per acre including office work of compilation and map work; they are necessary and useful. They merely sample by covering usually less than 5 per cent of the area; they do not leave a permanent survey or subdivision on the ground; they are not easily controlled or checked; any verification requires a repetition of a large part of the work, and even then it is usually impossible to decide the merit of the case, for. the inspection rarely follows the same line followed by the crew in the first place. Leaving no permanent survey marks, a later repetition, verification or correction is impossible, unless the matter of land survey is specially attended to. Nevertheless the results are useful, and often surprisingly accurate. The maps and descriptions alone justify the effort. Where the strip method and caliper crew are employed, the results are accurate for the samples actually measured, but they are inference for the rest. In this way the estimate of timber, for instance, may be fairly good as an average for a large area (township, stream-valley) but may not apply at all to a particular forty-acre tract. But in actual operations, logging, etc., it is usually desirable to know just what the forest is on a given forty and even the lumbermen have found it necessary, therefore, to amplify the information by a detailed examination, an estimate by forties.

With these limitations, the Preliminary Survey is useful; it may quite suffice for many years in cases of remote properties with little or no market ; it is quite sufficient for protective forests, "timberline" country, etc. On properties or parts of properties with good forest, with market for timber, and consequent development, the work of utilization with its improvements, of protection and silviculture, soon calls for more accurate and more detailed information. And especially do these lines of work demand that any information apply to a definite location, to an area clearly marked on the ground so that it can be found without repeating surveys, and to apply to 
an area small enough so that any work can be inspected, any results be verified, and any task repeated. But this calls for a Detail examination based on a definite subdivision of the land.

\section{Detail Survey, or Examination of Property.}

Since the information in this case is desired by definite areas the task divides itself naturally into:

Division of the land into suitable tracts.

Orderly covering of these tracts in making the estimates, descriptions and maps.

\section{a. Land Division.}

In level country and where the land is subdivided by United States Survey, the smallest actual division is a Section of 640 acres, and the lines and corners clearly marked on the ground, the description and estimate may be started at once without further subdivision. But even in this case, (which is rather the exception) it is desirable that the information be gathered by smaller areas, usually by forties or by 80 -acre tracts. This latter especially commends itself.

Where the survey is old, badly done, monuments and marks largely destroyed, it is a waste of time, in most cases, to have the crew which describes the property, hunt up and re-establish the land survey, and it makes for efficiency and accuracy to make a separate task of this work. In this case, especially, it adds but little to the total expense per acre to have the Section subdivided into eight lots, by running the middle line E. \& W., and marking on all F. \& $W$. lines the $I / 8$, as well as the $1 / 4$ posts. In level and rolling country not covered by United States Survey, the United States method should have preference. In hill and mountain countries, or parts of such where the rectilinear survey is unsatisfactory, or where no survey exists, the subdivision should adapt itself to topography: Here the ridges, primary and secondary, together with the streams, normally form the permanent bases. The lots are no longer of regular form and size.

The danger here is two-fold:

To make the lots or tracts too large, and

To make the lines on all ridges too crooked; both should be and can be avoided. 


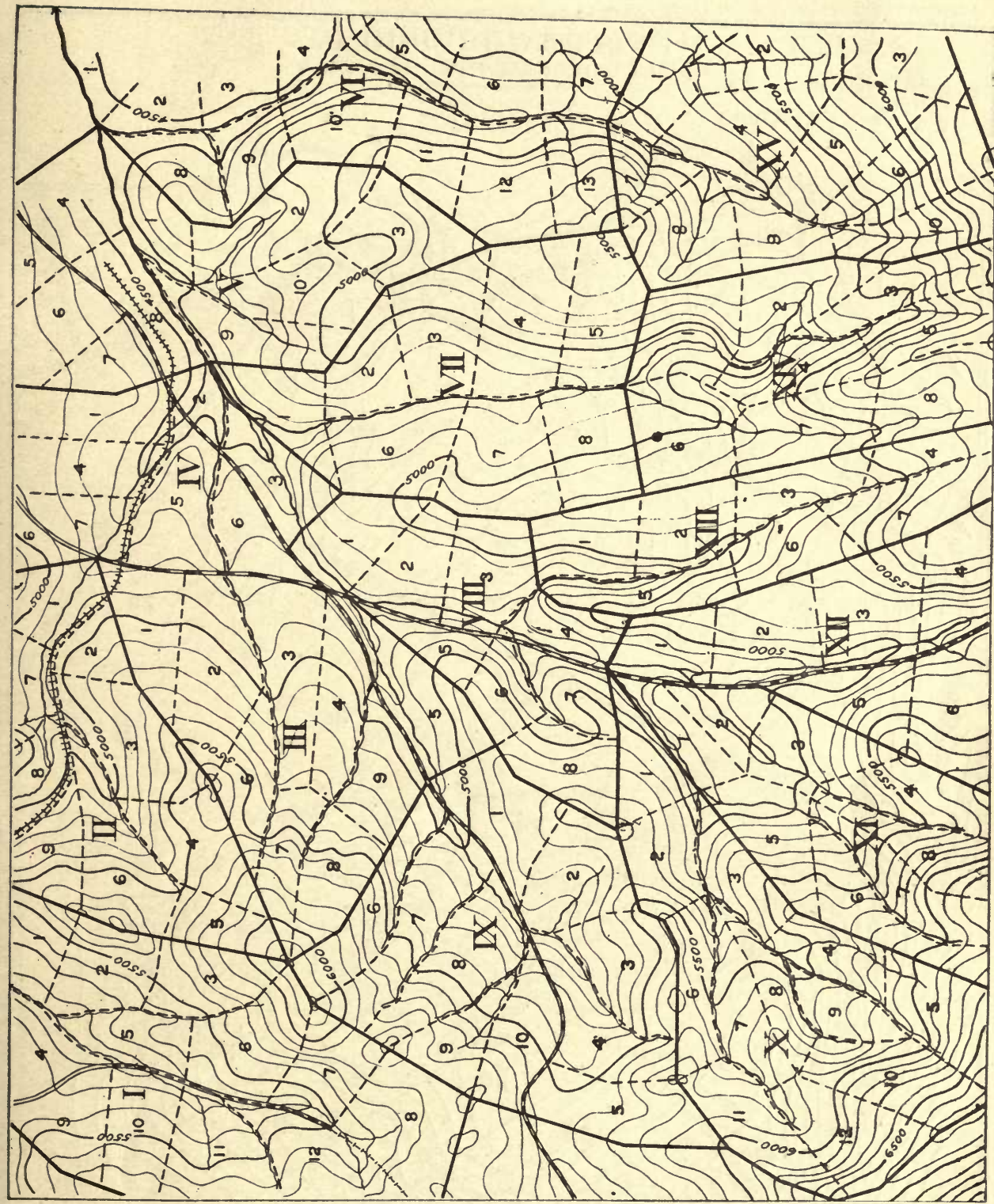

PI,ATE I. Study in Division of a forest in the Sierras. Scale about $\mathrm{I}^{\prime \prime}=\mathrm{I}$ Mile. Contour intervals ico ft. Fifteen blocks; of these only 5 complete on this map. Average size of blocks about I 600 acres; average size of lots I7o acres. By Alfred Voigt. 


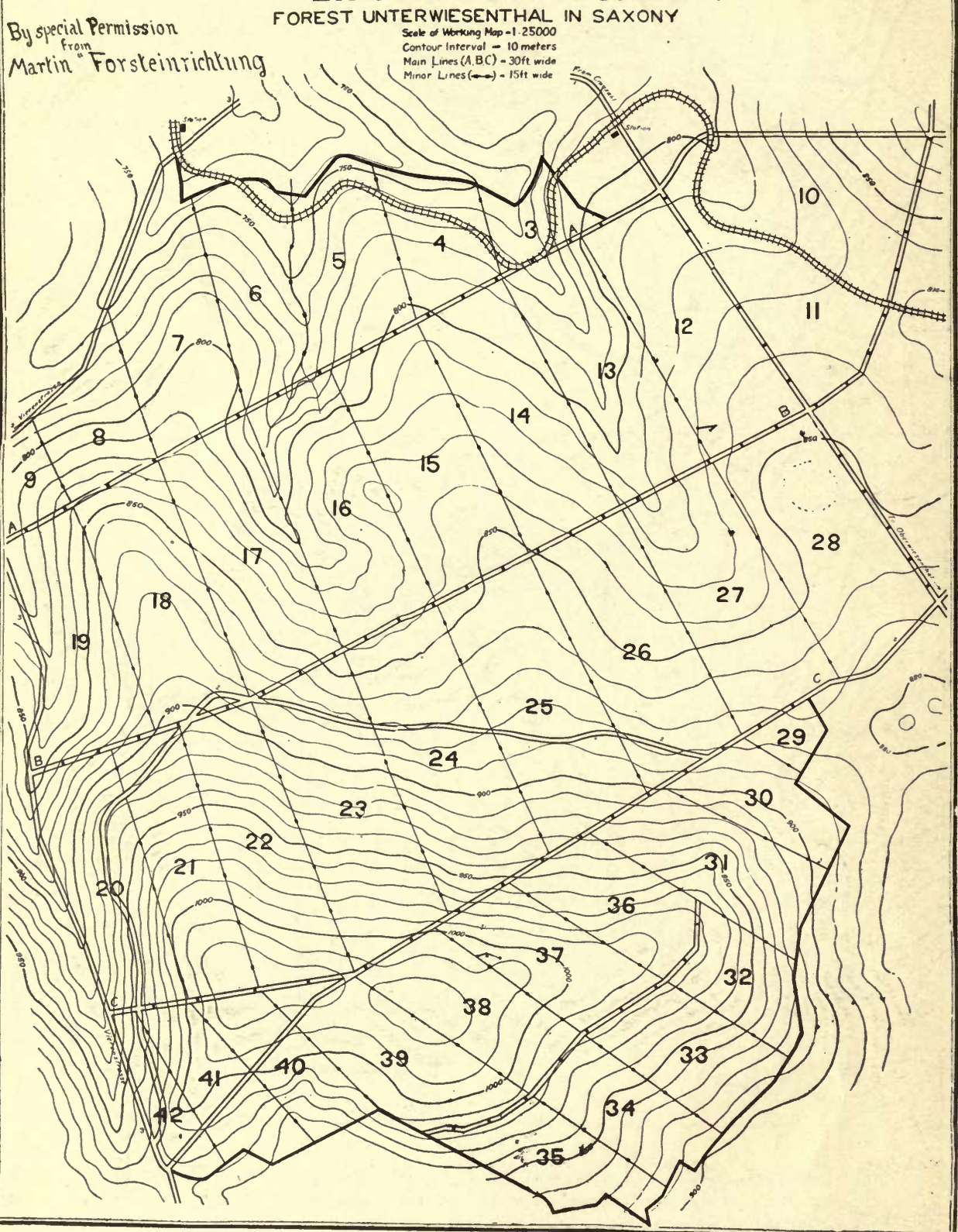

\section{EXISTING DIVISION.}

Martin "For sleimrichkung 


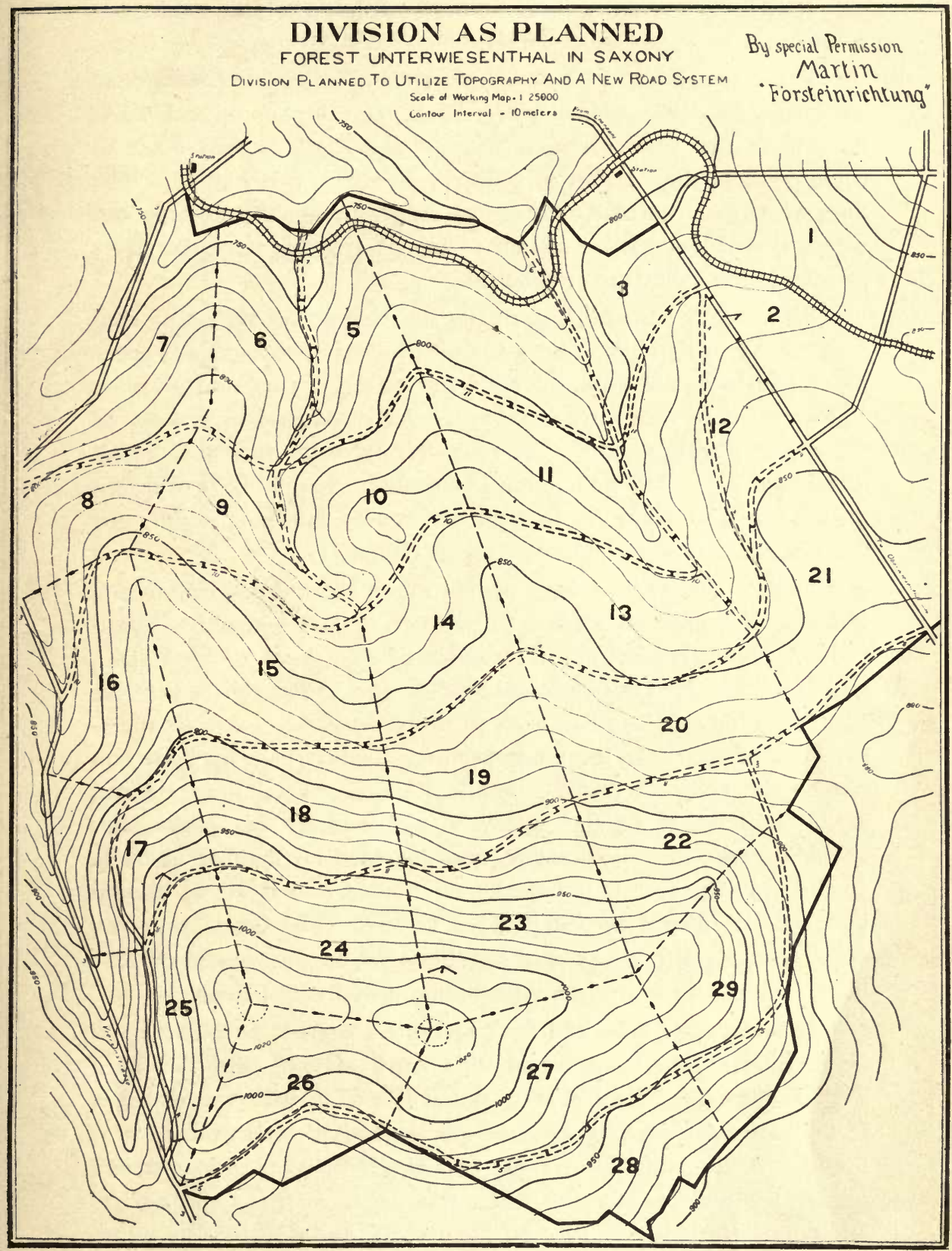

PLATE, 3. The same tract as shown in Plate 2. The Division is adapted to the topography and is largely made up of well planned roads. From Martin, "Forsteinrichtung." 
It is feasible even in high mountain districts to stay below 200 acres in the average size of the lot.

For convenience the lots of one stream valley, or part of one watershed may be combined into a Plock, and the lots of each block have their own series of numbers, and the Block is thus made to correspond to the Section in ordinary Survey. See Plate I. The lines of division normally follow the ridges or use the streams and where the distance from stream to top of ridge is too great lines parallel to the valley are established.

Since roads and trails, normally use ridges and valley, or connect these two by oblique lines to suit grade and topography, these roads and trails are used, later on, in perfecting this land division. But even where such a road system is well developed, as in scme of the recent European work, the roads rarely make over $40 \%$ of all division lines in hill and mountain country, and it is probably a mistake to allow this use in land division to influence unduly the planning of a road system. See plates II and III.

Of late, efforts have been made to base a detail description and estimate of timber on a partial and more or les's temporary subdivision. (See Diagram fig. I.) A set of base lines or "controls", tied into a regular United States land survey, are established by use of solar transit and stadia, or chain measurements. From the principal one of such a series, a number of secondary bașe lines are run out on the ridges between streams. On all control lines stations are established at regular intervals, and number of station, and altitude marked on monuments, and recorded on map or in book. In this way the area is practically subdivided into tracts of several hundred, to several thousand acres in size. The description and estimate-work then starts at the stations set on the control or base lines, and tries to secure the information, usually by forties.

If the control lines and their stations are made permanent and maintained in usable condition, this work may be regarded as a partial, permanent land survey and will well justify the expense. If the entire system of lines is temporary and allowed to disappear, the work serves only the purpose of a single survey and is certainly wasteful. In either case the description works on areas and reports on areas not actually marked on the ground, and thus has the short- 
comings of the preliminary survey, as stated above. Since the mapping and description work is done in detail, this method is a combination of extensive and intensive work, with doubtful justification.*

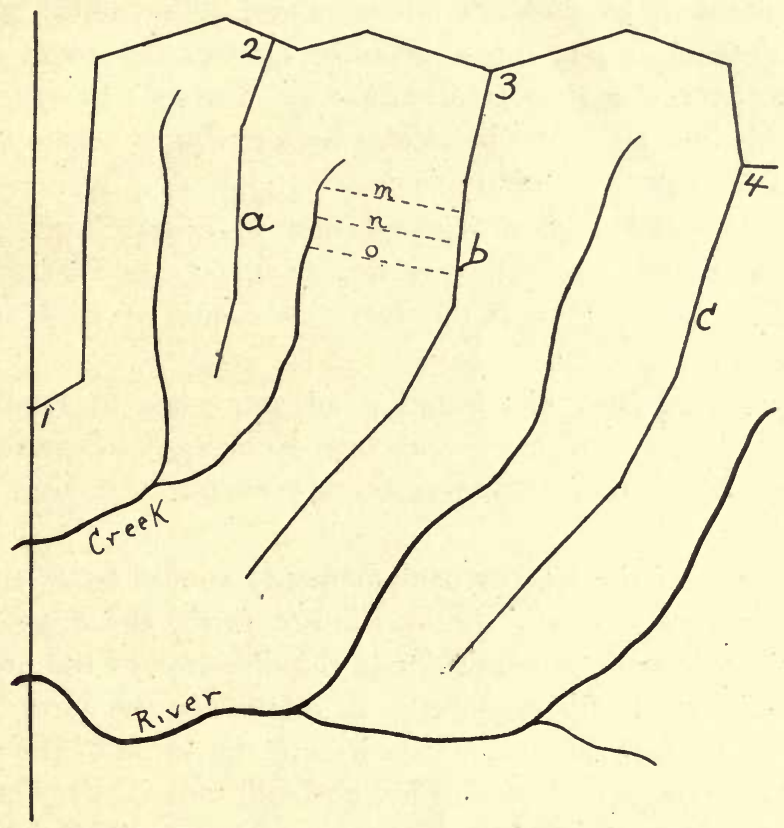

Figure I. Primary and Secondary "Control" or base-lines. Line I, 2, 3, 4 is here the principal line, a, b, c are secondary lines. Dotted lines $\mathrm{m}, \mathrm{n}$, and $o$ are lines of travel of the crew estimating and describing the timber. At $I$ is a Section Corner, here used to "tie in."

\section{b. Use and Value of Subdivision in Forestry.}

The value of a good permanent subdivision on the ground not only in Survey or examination of the property, but also in Utilization, Protection, Silviculture and even in Improvenents, but most of all in proper Administration and Bookkeeping, is very great. It was fully appreciated by Cotta a hundred years ago, and Martin

* These base- or control-lines may be established by a crew of four men; transitman, recorder, rodman, and axman (changes in this to suit timber, etc.). This crew in fair country can do two miles per day at an expense of about $\$ 10.00$ per mile. Stations usually every ten chains, with number and altitude. This crew maps along line; measurement by stadia. 
today emphasizes its value when he says: "The division of a forest into suitable lots ('Wirtschafts figuren') must be considered as one of the most important tasks of the field work." (Page IV, Forsteinrichtung.)

The necessity of such a subdivision and of having all information by definite, small tracts is fully appreciated today by the lumberman who demands information by "forties", in spite of the fact that his interest in the particular area or forest ceases with the cutting of the merchantable timber.

The forty as a unit of land division, of course, came into the timber business through the practice of the United States Land Office which has long used the forty as a unit of land area and land disposal.

Intensive forestry has found it advantageous to subdivide to areas even below 40 acres, and few European foresters would recommend lots larger than 160 acres even on poor sites, and in rough country.

The form of the lot (or compartment) should be as simple as possible; in level country the rectilinear form, twice as long as wide, with long axis perpendicular to the direction of the prevailing wind, is quite generally employed. In mountains the form becomes irregular, but too great irregularity lessens the value of the division and usually adds to cost of division and still more, its maintenance.

The Division, the Lot (compartment) is a land division, it is permanent; it does not change with operations of Silviculture, etc.; it is independent of the stand of timber on the land, or its condition of type, age, etc. Usually it is recommended to include in one Lot only one type of forest, only one kind of land, etc., but this is not always practical. Thus in the Great Lakes Pinery it is a common thing to find on one 8o-acre tract conditions as per diagram, figure 2.

In this case, three distinct kinds of land, leading to three distinct kinds of woods occur on the 80-acre lot. To separate these three types along the crooked lines of the border of the swamp would not help things, but rather complicate. Here the lot as land division includes three types, three sites, and the forester in his description and in future treatment separates these three as Sub-lots.

Sub-lot is a stand-division within the Lot. In the above case the three Sub-I ots are permanent, but this is not always the case. 
Thus in an 80-acre lot of pine, all 50 years old, a storm or fire may destroy the middle portion and necessitate its removal. This area is at once replanted, and the 80 -acre lot now has a 50-year old stand in the North, and another 50-year old stand in the South end, with a young plantation between these. In this case the forester would

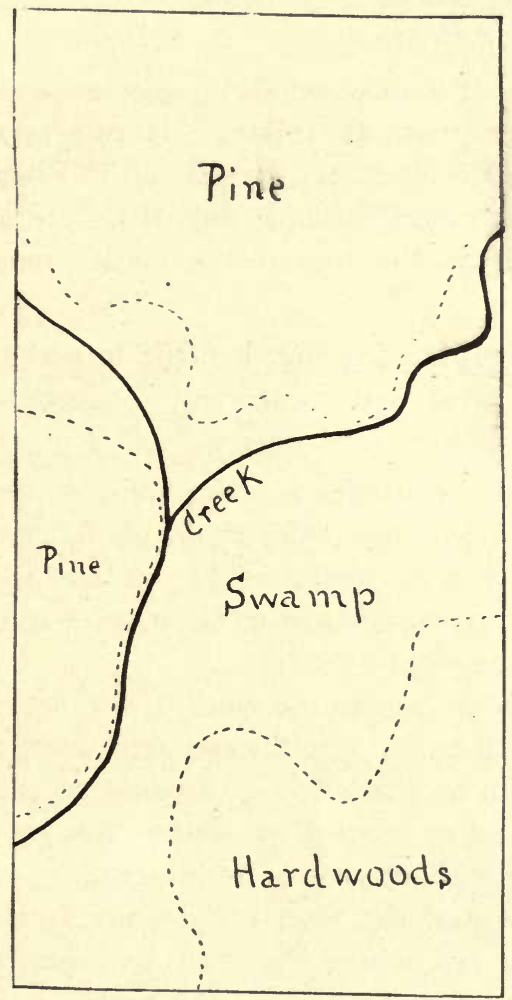

Figure, 2. Eighty Acre lot with types of land and woods, Pine Hardwood, and Swamps, leading to permanent Sub-lots or Stand-divisions.

make an effort to get rid of this condition of three Sub-Lots, by regulating the cut, and the Sub-Lots would disappear at the latest during second Rotation.

The Lot (or Compartment) does three things:

It limits every stand of timber, etc., on the property to a piece of land snall enough for proper location, small enough to enable its being found without delay and extra expense. 
It helps to make everything accessible; even a blazed line helps in going to a particular place.

It creates, or helps to create small, independent woods, an arrangement necessary for good Silviculture in all forests of even age stands, and useful even in the Selection Forest.

Subdivision of the forest is useful to all the important lines of work connected with forestry. A few points deserve special mention :

I. Land survey and Boundary. Here a good subdivision on the ground helps to maintain, verify and relocate parts of the boundary; it helps especially with regard to interior holdings; and it helps constantly in the use of the maps prepared in the land survey.

2. In Topographic Survey, it helps to make, check or verify and correct the survey; it locates all topographic features, and makes the topographic survey more useful.

3. 'The Timber estimate is more valuable if made by definite forty or lot. A lumberman who would gladly pay $\$ 2.00-\$ 5.00$ per forty for an estimate by forty, would not care to buy an estimate which would only give large averages, or refer to areas not marked and therefore of uncertain location.

Subdivision helps to plan the work of estimating and describing the property; it makes for a better estimate, since any one tract can be finished and can be treated in estimating according to its needs. It also enables proper control or supervision by checking, and it enables repetition without cost of re-location.

In timber disposal the need for definite location is evident; a scale record must tell where the stuff was cut; an application, a report, a contract must state where the timber is located.

4. Plantation, Thinning, Improvement work generally require definite location; the work is better planned, easier directed, better reported and booked; and only a definite location enables satisfactory inspection and supervision.

5. Protection is helped by subdivision; it makes the woods more accessible, enables the ranger to know his forest, stimulates interest, locates any damage and gives meaning to the report.

In many localities a well blazed division line helps to prevent trespass; and in all cases it facilitates prosecution. 
6. The preparation of Working Plans, their continuance and improvement; a proper inventory and set of records of a forest property all require a division of the property into parts or lots. And to be of value, these divisions must be small enough so that any stand of timber, plantation, improvement, etc., worthy of record is located and can be found without the expense of a special survey.

\section{c. Descriptions, Estimates and Maps.*}

This work involves an orderly going over the property, mapping and describing land and forest and estimating the merchantable stuff on every lot.

\section{Covering the Land.}

The lumberman frequently counts all merchantable trees on a forty by going several times through the forty. For his purpose this is a complete covering of the ground. Usually this is not done, the forest is sampled by going once or twice through each forty, examining in detail a strip 4-8 rods wide, and assuming that this strip fairly represents the forest on this particular forty.

In open timber, old stands of Southern Pine, Western Yellow Pine, etc., even this going twice through the forty permits seeing practically every acre of the stand, but does not usually count every merchantable or large tree, and gives no chance of study of smaller stuff except along the line of travel.

In such open stands the estimate can readily cover four rods on each side of the line, or an eight-rod strip, which, by going twice through the forty means a cover of $20 \%$ of the area. Where a caliper crew is used, the strip is normally four rods total width, or two rods on the side, and thus forms $10 \%$ of the area. A $5 \%$ covering, i. e., going once through the forty, may be considered the minimum in useful detail survey. $\dot{\hat{f}}$

In going twice through the forty in young timber, and also in brushy, denser stands, the forester does not see much beyond the four-rod strip and practically $90 \%$ of the stand remains unseen.

* Most of this subject belongs to Surveying, Mensuration and Description, and only a few special points are mentioned here.

† See: Margolin; Errors in Estimating Timber; Forestry Quarterly, I9r4, p. 167 ; giving interesting comparison between $5 \%$, 10\% and 100\% cover. 
Where the trees on the strip are calipered the estimate of merchantable timber is restricted to the strip. The same is quite generally true in ocular estimate, for the sampling requires orderly procedure. But the description does not tie itself to the strip but covers all the territory clearly seen from the line, a much larger per cent of area.

In all wild woods survey the matter is complicated by special conditions. Thus clumps of old trees, containing large amounts of good timber may occur off the strip in the midst of a stand of sapling or pole stuff. If these clumps are not examined and estimated, the entire forty may be reported as being without any merchantable timber whereas in fact it may contain a great deal. Similarly cases of bare ground, burns, swamps, windfall, etc., require a departure from the regular program and a special survey to ascertain the extent of such a burn, etc., is necessary in good work. Just where the limit should be to which this may be carried in any given case, depends on the use which is to be made of the information, and the value of land and timber, or the property to be examined. Thus far the error has generally been made on the side of economy, and certainly a detail survey reporting a forty as having no merchantable stuff when in truth it has half a million feet, is sacrificing too much to system and instructions.

From the foregoing it is apparent that the work should not be too mechanical, should adapt itself to the conditions, and in every case it should cover the ground sufficiently to avoid gross mistakes. Where stumpage exceeds $\$ 6.00$ per M. ft.; where the timber runs $500 \mathrm{ft}$. and better per tree, and In M., or over, per acre, and especially where the estimate is to serve as basis of purchase of the property, it pays to count all trees and estimate or measure their diameter.

Crew and Results. The old-time "cruiser" usually went alone, kept course, and distance and did the estimating. Later on a compassman was added as helper, to keep course and distance. The caliper crew usually consists of four men; compassman, tallyman and two calipermen. Here the compassman keeps course and maps; the tallyman keeps tally and describes timber, the calipermen caliper the timber above certain diameter on the four-rod strip. Of late there is a return to the two men crew, with pacing and estimating 
in place of chaining and calipering. As in the covering of the ground, it is doubtful if any one set form of crew should be used in all kinds of timber. The four men caliper crew, without doubt, is the most competent, accurate and reliable, especially where inexperienced help must be employed.

These crews commonly do not finish any particular forty, but. go one, two, or even more miles in one direction, i. e., through several sections and then offset and return. With ordinary compass and on rough ground this is a questionable practice; the crew is almost sure to get off the intended line, and it is not uncommon for a less experienced crew to miss the forty entirely.

On easy ground and in uniform timber a crew covers about two miles of strip, and thus measures sixteen acres of strip, so that, on a $10 \%$ cover, it finishes one section every four days, at an expense of about eight cents per acre. On rough ground and in brushy timber, the cost increases 50-100\%.

\section{The Information and its Record.}

The examination of a forty or lot involves usually two rather distinct parts :

The estimate or measure and tally of the merchantable timber, and

The description of site (soil, etc.) and forest growth or growing stock, this latter usually including notes with regard to the condition, quality, age, thrift, etc., of the merchantable material as well as the rest of the tree growth.

Of these two, the description is of more importance in regular forestry, takes more preparation, knowledge and time. The estimate or tally is primarily a record of dimensions taken by species. In timber under 12 " the record may well be arranged by diameter classes of one inch; in larger timber the record is sufficiently accurate if taken by $2^{\prime \prime}$; and in timber over $20^{\prime \prime}$ d. b. h. $3^{\prime \prime}$ diameter classes are permissible.

In the earlier efforts it was thought best to reduce the amount of information to be gathered, to as few simple points as possible, and thus gain in speed or economy. Accordingly the printed forms had but few columns; each column covered a variety of points without clearly asking one definite question, and a good deal was left to the colımn of "remarks". The man in the field was in doubt, 
the matter seemed largely optional, much information was gathered for one forty and little for the next one, and much information was fragmentary. When these field sheets came to the office, only that part of the notes could be compiled which was gathered uniformly and consistently, such as the tally material, and the rest was not copied at all, or else "doctored" and inferred, and statements of the most extraordinary kind were often the result. ${ }^{1}$

In deciding this matter, it is well to keep in mind the following points:

a. The information must serve all lines of work. It should tell the owner what the land is, upon which the entire forest enterprise rests and depends; the proportion of good, medium and poor land, exactly as in farming.

For Silviculture one must know site and species, and behavior of the species; difficulties and dangers to be met and avoided.

Utilization requires knowledge of material on the ground, topography, obstacles and advantages (streams, etc.) affecting particularly transportation. For Protection the above, and also matters of debris, windfalls, fire and insect injured stuff and everything that affects the safety of this property. And it is not enough to know that a large windfall of inflammable material exists, but it is essential to know exactly where this menace lies, and what stands of green timber are endangered by it.

Regulation and Administration require all the foregoing, and much more, and need to have all this information by definite location.

b. The gathering of this information costs time and money and cannot be repeated, except at long intervals, (ten years, even in intensive work).

Probably over $75 \%$ of the money is spent in getting the man to and over the particular forty and not $25 \%$ is spent in actually describing the forty and measuring and tallying the timber. To save on this part of the work then is generally false economy.

c. The man on the ground is the only man who counts, measures, and describes with conditions before and around him; what he puts down. then and there, is fact, or, at least, it is fair estimate;

${ }^{1}$ In one case the soil was evidently neither described nor examined regularly. and the final report stated that an area of about 60,000 acres was "sand over hardpan," a condition probably not applying to $\mathrm{x} \%$ of the area. 
any later changes and inferences are guesswork and usually work away from and not toward the truth.

If properly prepared this man can see and estimate numbers, sizes and other conditions and he can put down figures, etc., in fifty columns in little more time than it takes to fill twenty-five. In fact fifty columns, each asking one definite question, are more quickly filled than fifteen columns in which more or less of a mixture of information is asked, or in which matters of judgment are demanded which require study on the ground.

d. The printed form of description should ask the information in definite questions, one point at a time and in one column; it should make the work as simple as possible, discount memory, avoid all calculations and study and merely ask the field man to put down what he actually sees. Inference and suggestions for the future should be kept separate and not mixed up with recorded facts. Whatever is not definitely asked for in the sheet, is certainly never supplied regularly even by the best of field men.

e. The man on the spot, if properly prepared, should be able to make a few important suggestions as to the future, and future treatment of the stand, and these should never be omitted. The man in the office who plans from this report may never see this particular stand.

f. Wild woods are complex; they vary from acre to acre and a description such as is made by the German forester, where the stand is purc, uniform, even aged, cared for, and where soil and topography and origin and growth of this stand may have been described several times before, does not suffice.

g. Forest estimates and descriptions are made under conditions where it is difficult to control the work. The work, therefore, needs well prepared, honest men. And even then it should be inspected and verified all along; the field sheets and maps should be examined regularly. Men should be given ample time to do the work well; driving leads to mere thoughtless travel of the woods.

\section{The Description Sheet.}

In the past forms with ten or even less columns were common; today about forty columns are used in the complete sheet (merchantable timber and all) and the tendency is toward more columns. 
Sa mple Field Sheet.

(Turned, for Convenience of Printing.)

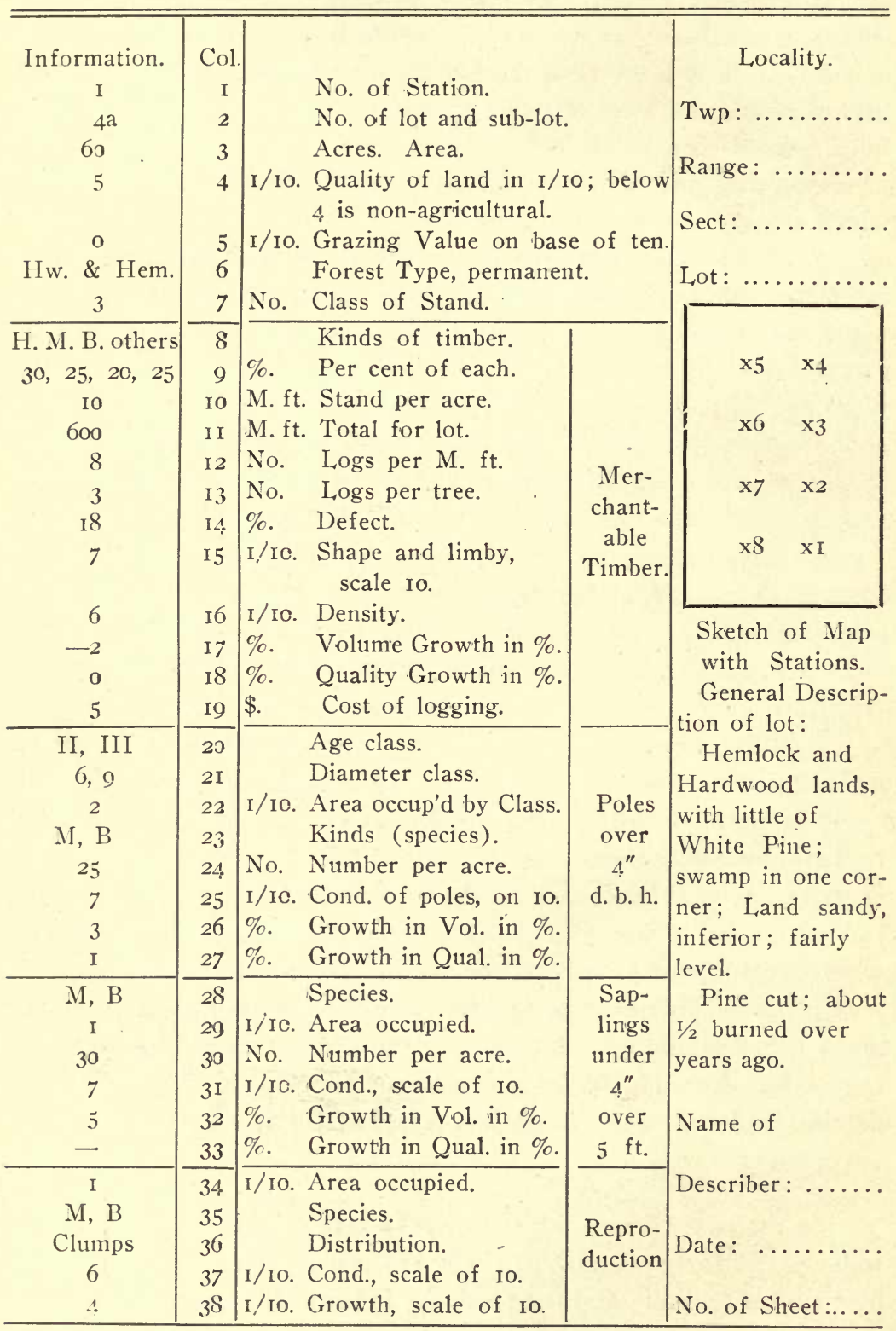




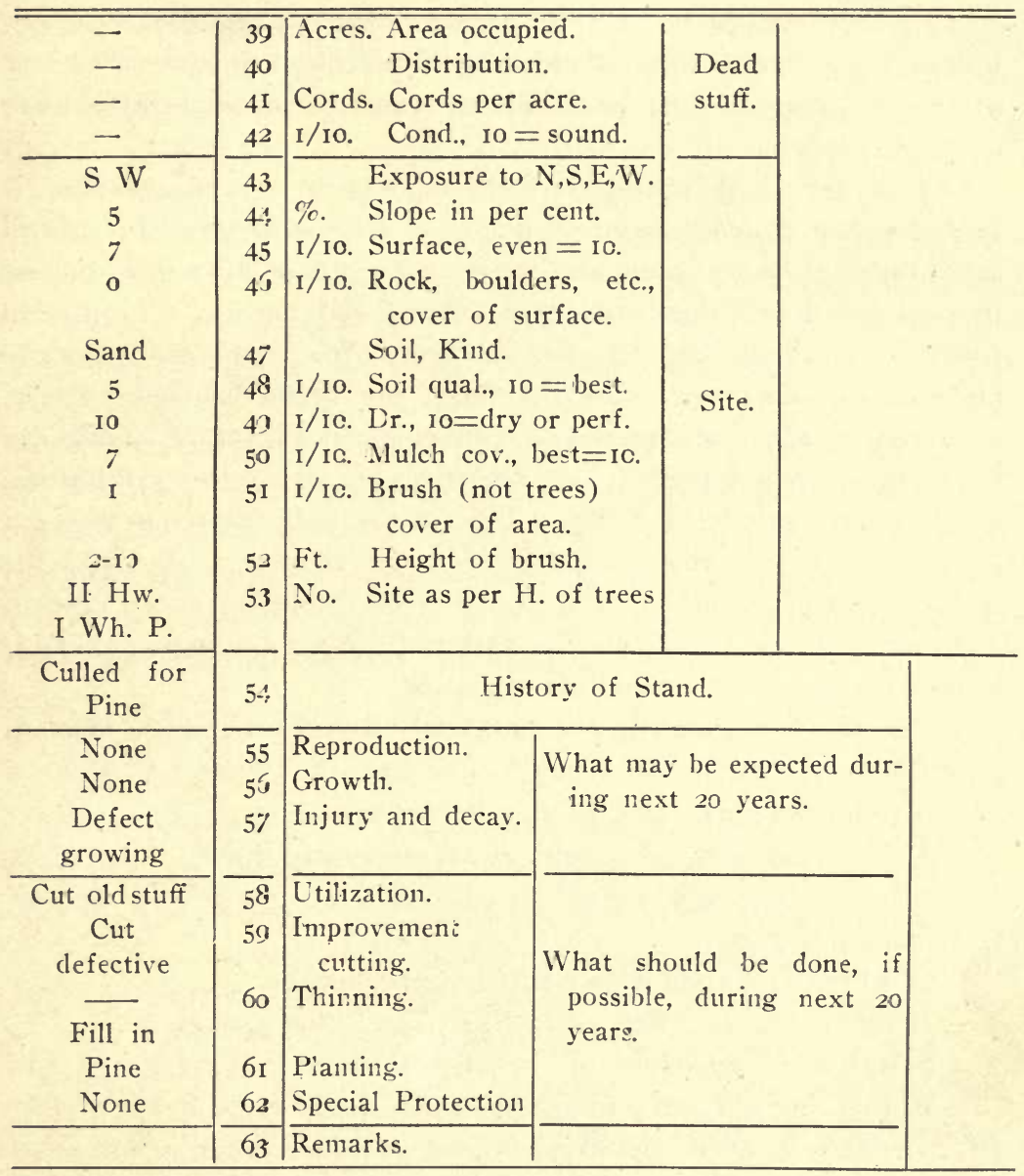

In arrangement of the field sheet and system of taking notes it is well to keep in mind :

a. 'The compilation of the information, which requires that everything is arranged so that classification is convenient.

b. That numerical statements are much more definite, more convenient to make and compile, fully as expressive as words. If three classes of soil are made, it is just as clear and expressive to set figures I, 2 and 3 , as to state: good, medium and inferior Tand, etc. 
c. Few stands furnish information for all the columns, but this is impossible to foresee and it is inconvenient to carry a variety of sheets, suited to different kinds of stands, so that a single form deserves preference.

The preceeding sample is intended merely as a suggestion; it is convenient to use; requires not over fifteen minutes for a full description at one station; and thus not over two hours per mile of line where descriptions are made every 220 yards. In uniform forests conditions, half that time suffices. The items are generally understood, and used, except, perhaps, the Stand Classes. These, as here intended, are merely a convenient division of stands on lines involving not merely age, and size, but also other conditions. Thus in pure stands of Norway Pine in the Lake States it may not be feasible to describe accurately by age classes; and while the caliper tally gives information as to sizes found on every acre of strip actually measured, and in part indicates age classes, there is some advantage in a further classification.

The following classes are commonly found on a large tract of pure Norway Pine in the Great Lakes Region:

All-Old over ripe stands, rapidly deteriorating,

All-Old, fire injured stands, in uncertain condition,

All-Old (even aged) good stands which may be safe for twentyfive years and more,

Old broken stands with natural reproduction,

Middle age, and "Second Growth" or "Pole" stands and

Stands of "Reproduction" or thickets of trees $\mathrm{I}-20 \mathrm{ft}$. tall.

In this case it is easy to recognize the stand class and it is help$\mathrm{ful}$ to record it, as it corroberates and amplifies other information. In doubtful cases it is of little consequence whether the stand is placed in one or in another class. Where this classification is employed, it is well not to-make too many classes, since then the difficulty of distinguishing them offsets all advantages of the classification.

\section{Computation of Volume.}

This applies chiefly to merchantable timber. In the practice so far developed in the United States the volume of trees calipered or estimated for their diameter, has been computed from Volume tables. This is perfectly natural and proper, and will undoubtedly 
continue to be done. Care should te taken to test the tables used; and tables based upon one height for each diameter should not be applied to stands of taller or shorter timber. In emergency cases the form factor can be used to adapt the table.

European practice frequently uses the Draudt, or the Urich methods, but in most state forests the ocular estimate is permissible, and the use of Volume tables, like the old Bavarian talles is again coming into favor. Where the Urich method is used, recent instructions, like the Bavarian of 1912, prescribe the felling of not less than $\mathrm{i} \%$ of the total stand for sample material to compute from. On a forty-acre lot with 6000 trees, this method calls for the felling of sixty trees, to be worked up into the usual stuff and measured and scaled. In Pavaria this is feasible in most localities, and readily indicates not only the total volume but also the grades and with this money value of the stand. In our country in localities remote from mill and road, the sixty trees and all the labor of cutting would be wasted.

\section{The Mapping.}

This, in good field work, is now done on a scale of $8^{\prime \prime}, 12^{\prime \prime}$ and even 16 " to the mile. The work usually notes: land division, topography, streams, roads, etc., forest types, burns, grazing and waste lands. Clean work avoids crowding of material on sheet, and especially the use of blunt crayon, etc., the ideal being a map which can readily be copied by anyone.

Topography in mountains is commonly taken with aneroid; some form of "percentor" has advantages, especially in easy rolling and relatively level country.

\section{Accuracy of the Work.}

In securing merely the amount of merchantable timber and especially in old, defective timber, the experienced cruiser has advantage over a less experienced man, even with better methods. Generally, however, this is not true, and the results of the forester's work, using methods which can be planned, criticised, adapted to conditions, checked at every step, and fully explained in court, deserve the preference. Nevertheless one hears occasionally: "But you are not accurate, a bridge engineer can estimate the amount of 
material, and the costs to one or few per cents and be certain of his figures, then why cannot you do the same?"

But if the engineer's material were scattered promiscuously over miles of country, and no two pieces alike, and none of any accurate geometrical figure, none in position to weigh or actually measure, he would probably prefer not to estimate at all.

Generally, ten per cent must be regarded as an attainable, and also a satisfactory accuracy in forestry estimates of volume. In most forestry work the estimate of the merchantable stuff is not used as final measure; the logs are scaled when cut, and it is usually far more important to have a good description, to record the condition of the forest on a particular forty than to try for great accuracy in the estimate of Volume.

\section{SPECIAL STUDIES IN THE FOREST.}

In the examination of large wildwoods properties it is usually desirable, almost necessary, to add the following:

a. Preparation of Volume Tables of the important kinds of timber;

b. Preparation of Yield Tables;

c. Study of the Behavior of the important species, and the injuries of the recent past as well as the principal points of danger;

d. Special study of conditions not really of the forest, such as grazing lands, camping grounds for tourists; peat, gravel rock deposits, etc., which may, in time, become sources of income.

\section{a. Volume Tables.}

These tables give the volume of the individual tree and are usually of two kinds, one based on diameter breast high, the other on the age of the trees.

I. The tables based on diameter state that a tree $I 2^{\prime \prime} d . b . h$. $14^{\prime \prime}, 16^{\prime \prime}$, etc., contains a certain volume, either in cubic feet or feet board measure. They are useful, primarily, in the computation of the results of estimates or caliper measurements as made during the survey, but they give no information as to the rate of growth of the tree. To be of use for the timber on different sites (soil or altitude) 
they require values for different height classes. 'The data for these tables are usually gathered in connection with regular timber cutting, so that the results may not only be stated in board feet or cubic feet, but may give the number of railway ties, poles, piling, cords of pulp or cooperage stock, etc., and in this way the value of the tree on basis of prevailing prices.

'This work may well be done by 2 men crews, and usually takes the following measurements : total height; height of stump; number of logs, and total length thus actually used; clear length, and length which could be used; diameter breast high, outside bark; upper diameter of each $\log$ inside bark. The scale of the logs bases itself on length and diameter and leaves out of consideration crook and defect, as accidental.

2. Volume tables based on Age, state the volume (and usually height and diameter) of the tree, at the age of ten, twenty, thirty, etc., years, and thus indicate the rate of growth of the tree. The data are gathered by partial, or by complete stem analysis.

a. Partial analysis. If in the process above described, the rings on the stump are counted and thus the age of the tree is ascertained, the data can be arranged according to age instead of diameter and a table can be prepared which gives the volume of the tree at different ages. That the same data can also be used to prepare the table based on diameter, is evident.

b. In Complete stem analysis the rings are counted on the stump, at the end of each $\log$, and usually at one or more cuts in the top. In addition to being counted they are measured, from bark in, at every tenth ring, so that a table and a diagram can be prepared which shows the size of the tree at time of felling, ten years, twenty years, etc., before felling. From this diagram and table a curve is made for each tree and the rate for the several trees thus graphically averaged. This is one of the most useful, instructive and reliable lines of measurements in forest work. As far as any one tree is concerned, the results are as accurate as the form of the tree permits.

Only good trees should be used. A great deal of information is obtained from one tree; thus a tree 150 years old tells of its height, diameter and volume at ten, twenty, thirty, etc., years and thus gives accurate information, which in the partial analysis would require fifteen trees. In addition it presents the actual growth of 
a good tree throughout life, while the partial analysis does not give this for any tree. The information applies usually to dominant timber, the kind composing the final crop. While, generally, a large number of trees are called for, it is surprising how uniform and how reliable is the information even from roo trees.

In all growth study work, only the valuable species are considered. The study of growth on different sites multiplies the task and adds very materially to the cost. While apparently very simple and mechanical. this kind of work requires a well prepared, thoroughly interested and faithful worker.*

\section{b. Yield Tables.}

Present the volume of the Stand of trees per acre, at the age of ten, twenty, thirty, etc., years. They are, therefore, not merely tables of yield, but also tables of growth, indicating the rate of growth of the stand.

For older stands (merchantable) it is desirable also to know the amount of material in form of ties, poles, etc., i. e., in the usual forms into which the particular timber is converted, and thus to learn not only the volume, but also the value of the stand per acre.

Yield tables are prepared for the different sites, and in their final form usually include number of trees per acre and also height, diameter and volume of the average tree.**

These tables assume a pure stand and even aged stand; all efforts to prepare satisfactory tables for mixed stands and for many age stands have failed, so far, to produce satisfactory results.

To secure the data for yield tables it is necessary to find pure stands of different ages, get their volume and by means of curves even up and complete the information so that it can be tabulated. These stands should not only be pure stands and even aged, but also fully stocked and in reasonably good condition. For these reasons only good stands are of any use, and the selection of these stands

* Ordinary Volume table work is done by two men crew; doing 50 trees per day; office work adds $50 \%$ to cost; I000 trees for about $\$ 2$ co- $\$ 300$. Stem Analyses by two men crew; do about io trees per day; office work adds I00\%; total cost about $\$ 1.00-\$ 2.00$ per tree. Varies greatly with timber, locality, etc.

** For models of completeness in Yield tables see the recent studies of growth of Pine, Oak, and Spruce by Schwappach. 
must depend on the judgment of the man in charge of the work. In ordinary wildwoods the selection of stands for yield table work is not always easy, in some cases impracticable.

It is much easier in conifers than hard woods, and generally easier for young stands than old. E,ven in pure stands, the variation in age, the irregular condition of the trees, and the question of stocking, complicate matters. The question whether a stand is fully stocked is not always easy to answer. The same stand of Pine roo years old, fully stocked, and in excellent condition, might have $20 \%$ less trees, and yet $10 \%$ more volume if it had been heavily thinned at the right time. Here then, neither the number, nor the volume fully decide the case. This whole matter must remain debatable until new stands have grown up under the care of man, and acceptable standards established. Generally a fully stocked stand must be accepted to he one on which as many good trees exist as have fair growing space under the given conditions of species and site.* Since the Yield tables as above inclicated deal with perfect stands, they have also been called Normal Yield Tables. In using them it is necessary to make allowances, for it is utterly impossible to develop all the stands of a forest through an 80 or 100 year Rotation without disturbance or accidents. In the Pavarian Instructions a reduction of $20 \%$ for Spruce and $10-20 \%$ for Beech is suggested.

Of late, Yield tables have been prepared giving the volumes over large areas as actually found. While these tables are of value as indicating actual conditions of the forest, their use in predicting the growth of timber on the particular site is rather uncertain, since the conditions of the wild woods are commonly too irregular and accidental to serve as criterion of what can be done in forestry. On the other hand the best 10\% (or less) of all the acres of mature stuff calipered may very well be used in setting a provisional Normai Yield for mature timber and thus also serve to determine

* This matter of Normality or what constitutes a fully stocked Stand ("Vollbestands factor") and how a stand is to be gauged, is still a debated point. For purposes of volume-calculations the prevailing German plan puts:

Degree of Stocking = Area of Cross Section of trees of Stand divided by Normal Area of Cross Section.

See also: Martin, "Forsteinrichtung" and Schilling's Comment in "Zeitschrift für Forst und Jagdwessen," I9I1, p. 582, and particularly Fricke, "Standorts und Bestandesbeschreibung" in same paper, I9I I, p, 227. 
the normal average yearly growth of ripe timber, two figures useful in the development of the Working Plan.

Similarly in mixed stands and many age stands, the actual Growing Stock of a fair number of the best stocked acres seems still the best basis for a provisional Normal Growing Stock and Normal Average Growth in these stands.

In all cases the yield table results may well be checked by the use of Volume tables and by a comparison with established tables for the same kind of timber. A good set of Volume tables, especially where attention has been paid to the "growing space" or area of land occupied by the trees of different sizes, deserves attention.

In setting the average age of the best mature stands it is well to keep in mind that the ordinary stand of timber (pure and even aged) does not increase, materially, in volume after a certain age, and that this age for most species is far within the limit of the natural Rotation or life of the tree.

In the field work of gathering data for Yield tables, a task well done by the valuation survey crew, it is well to select the stands carefully and to be satisfied even with areas of one-half acre, rather than complicate conditions. In hard pine, etc., stunted, dense stands must be avoided; preferably also very old stuff, since future rotations will rarely consider stands over 150 years old, and the majority not over ion years.

Considering the many difficulties in the preparation of Yield tables, the question may well be asked: Why prepare these tables at all? The answer is: Just as a farmer wants to know, and needs to know how muclı wheat or corn he can raise on a given farm, so the Forester should know, and the owner wants to know how much pine timber will this property produce per acre and year.

This is the function of the Yield table; and while the figures from wildwoods may never be very accurate, they will at least be near enough right to prevent foolish investment and utterly misleading statements, such as have already been circulated about Eucalyptus, Jack Pine, Norway Poplar, etc., in our country, and they will also prevent costly planting on miserable sites and equally so the tınwise penury of leaving good lands idle for want of proper planting. In the regulation of large forest properties, even approximate figures, if rationally based, will give assurance of continued supply, by preventing thoughtless overcutting of the forest. 


\section{c. Forecast Tables.}

These have also been termed Yield Tables. 'They state (forecast) that if, for instance, the stand is cut over to a diameter limit of $12^{\prime \prime}$, there will be a growth sufficient to make $3000 \mathrm{ft} . \mathrm{b} . \mathrm{m}$. in twenty-five years. They are based on the stand of timber left after cutting and its estimated growth, the assumption being that a certain. number of trees die (estimated) and that the forest continues to reproduce as in the past, and that the composition in mixed forests continue as at present.

Since these tables are based on the present, more or less accidental conditions of the wild woods they apply only for the immediate locality and for the immediate future.*

\section{d. Other Studies in the Timber.}

These involve chiefly the behavior of the important species of trees on the property.

I. Behavior of trees, notably:

a. 'Tolerance.

b. Site requirements, chiefly as to soil, and in mountains as to exposure and altitude.

c. Behavior of principal species in mixture.

d. Reproduction, frequency of seed years, abundance of seeding, etc. In hardwoods, also, the sprouting.

These facts as gathered at the first Valuation Survey are, of necessity, merely beginnings. The behavior of trees in any locality is not learned in one year, and experience must accumulate.

For this reason such a line of inquiry is treated briefly and

* 'Tables of this kind, though evidently worked out with a great deal of care, have not given us very satisfactory or convincing data. The following figures are taken from four different publications. The growth per acre and year of a stand cut to $12^{\prime \prime} \mathrm{d}$. b. h. is as follows:

Spruce (East) cut takes $2490 \mathrm{ft}$. per acre, growth is I03 $\mathrm{ft}$.

Loblolly (S. C.) cut takes $6190 \mathrm{ft}$. per acre, growth is $73 \mathrm{ft}$.

Pine (Ark.) cut takes $6060 \mathrm{ft}$. per acre, growth is $150 \mathrm{ft}$.

while according to recent studies the growth of Loblolly in Maryland on Site II, or average lands, is over $400 \mathrm{ft}$. per acre and year. Here a fast growing species in a warm climate is expected to grow only $75 \%$ as much timber as another stand of slow growing stuff on a cold site, and this in spite of nearly double the growing stock on the land. 
details deferred. Effective study of this kind requires a man thoroughly grounded in silvics, and if he is not to te had, it should be left at notes as gathered in Valuation Survey.

2. Injuries occur in all woods. They represent the dangers to the Merchantable Stand, present and future, and danger of immediate loss. They determine what must be done to protect the forests and often decide what species must be favored or used and also the methods of silviculture best adapted. Windfall prevents the use of various forms of seeding from isolated trees, and groups of such trees; it forbids shelterwood and seed tree in Spruce. Heavy snow forbids the use of Scotch Pine in parts of the Black Forest; the Locust beetle has prevented desirable woodlot work on the farms, etc.

a. Generally the forest tells its own story, and notes are gathered during the regular valuation survey. Besides occasional stops to determine the approximate age of a burn or other injury there is no call for special study unless some great trouble, like bark beetle pest, etc., is under way and threatens large values in timber.

Manner of stating these facts in report should avoid all lengthy discussion and relate the injury directly with loss in value, its effect on Protection, Utilization, Silviculture, Business. If special study is made of such trouble as an insect calamity, it is best made the subject of special report.

b. Special consideration is required by the conditions affecting fire protection. In the United States this must continue for many years, in fact until the woods are cleaned up and fire protection becomes an established custom. In this connection the areas of even aged dense young stands in conifers and the large masses of windfall and fire killed stuff require attention and are therefore recorded in regular columns of the description sheet.

To try to locate at once the best points for lookouts, tool boxes, phone lines, etc., is really beyond the scope of the survey and is much better done as a special enterprise in making the Plan of Protection.

\section{e. Report on Conditions other than Timber.}

Which affect value of property and its management. Such matters as: Lands needed for purposes of the forest business, mill sites, pastures, etc. 
Grazing areas.

Water powers, mileage of driveable stream, etc.

Canjp grounds for pleasure seekers.

Rock, gravel, etc., or materials which may be disposed of or used in the work on the forest.

I. In ordinary valuation survey these matters are merely noted as they appear to the forester. There is no time for exploration or study. If sufficiently evident and important they are made subject of special examination or else they are left for others to explore, as is usually the case in development of these special resources, where the future applicant does the prospecting and calls attention to the matter by request for purchase or lease.

2. Where grazing lands are of importance as on many of the National Forests, their examination is made a special task. The land is covered in a manner similar to that used in valuation survey of forest lands; and the facts are noted on a regularly prepared form in which the following items deserve consideration:

a. Area and topography and altitude.

b. Soil and drainage.

c. Cover, grass, or brush or both, kinds and density.

d. Quality of range by certain standards, i. e., I, 2 d or 3 d class grass lands, etc.

e. Injury, if any and cause of this.

f. Possibility of improving range.

g. Suggestions regarding treatment in the immediate future, to which should be added: Time when free from snow, i. e., open season; time when ready to drive in ; capacity to carry stock for this open season; access to area, and possibility of giving each man a separate range.

\section{INFORMATION NOT OF THE PROPERTY ITSELF.}

While this is now commonly omitted in Germany, it is of greatest inportance to us, where everything is new and changing, and where the owner nay le in New York and the property in Michigan or Idaho. 


\section{a. Logging or Exploitation, Methods and Costs, Effects on Forest.}

This usually involves:

1. What is done in this Vicinity with the Kinds of timber found upon the property. How much is cut, where, and by whom.

2. How is the work done, i. e., Methods of Logging, transportation, milling, including matters of labor, usual results and cost. Particularly the methods of logging and transportation of timber to mill require special study, and the principal steps of felling, cutting into logs, skidding (or yarding) loading, hauling, driving or railroading, the construction of roads, railway, camps, etc., all need mention.

3. How is the Material marketed, where and at what prices, including the consideration of value of material at different points, as logs in woods, at mill, as stumpage.

4. In what condition do these methods of logging leave the woods from standpoint of silviculture and protection.

5. Names of men who take contracts of logging, buy stumpage, or logs, and mills ready to convert timber on contract, etc.

6. Suggestions for improvement especially as to

a. Silviculture and Protection.

b. Economy in logging.

c. Opportunity of manufacturing the stuff by owner.

This set of information is very important, it is largely a matter of visits and canvass or inquiry, requires tact and preparation, and often can only be done through special, extended study by some person of considerable experience. In districts with special forms of exploitation such as Turpentine industry, tan bark, acid, pulp and extract wood; railway ties, poles, piling, cordwood jobs, cooperage, wagon stock, etc., these industries require attention.

\section{b. The Market.}

Needs special study, and includes both local markets and distant (usually large city) market as well as rates of shipment to these markets.

The large "World Markets", i. e., the big cities, at a distance are known, the prices paid or demanded are seen in Technical 
Journals, freight rates are obtained from Railways or shippers. It is desirable to know the firms now buying in the district where the property lies, and specializing in the kinds of timber on hand.

Local Market is of special value. Here come questions: What is bought, how much, who buys. Then also: what is the history of this market for last few years, and what are the chances of improvement by property owner by:

Special inducement to present buyers.

Bringing in other or additional industries.

This information, also, is a matter of canvass, requires tact and time. But the salient points can always be secured and should never be wanting, even if much correction is needed later on.

\section{c. Population and principal Business of the District.}

Chief considerations here are the effect of the people and their business on: Taxation, Protection, Labor, Market. In many districts as in the I-ake States, taxation has been boosted systematically by local people until cutting has been forced; grazing in the West opposes forest extension and good silviculture and in some cases ordinary fire protection; grazing in the Southern Pinery established the custom of "light burning" and prevented reproduction; the berry picker in Lake States Pinery and the tourist in many districts must be considered in fire protection, etc. Lack of labor in places prevents effective fire fighting in spite of all patrol and lookouts. The established custom of wood working in parts of the East, Lake Region and Canada, makes a cord of poor material (Aspen, tamarack, etc.) far more valuable and saleable than is the same material forty miles from Detroit. This information is gathered while looking after markets, logging, etc., and should be constantly in the mind of the Forester as he examines property.

\section{d. Contracts for Timber, Leases of Lands, Easements, Etc.}

Which may exist, are known to the owner or his agent. But the effect of these contracts on the forest, and especially on future management, are not usually known or understood. Such contracts are very common. In many cases it is a contract for all standing merchantable timber; or for certain kinds of timber (Hemlock and Cedar in Lake Region are preferred subjects), in some cases there 
is no time limit at all, in others it is a long time contract without limitation as to area, so that the man can return to the same lands and cut over the same tracts repeatedly according to changes in market. The effect of such conditions is evident; and all rational, systematic treatment of the woods is impossible unless the contract is removed by purchase, or is modified by agreement and compensation. The statcment should point out clearly what the contract is, its history to date, injury to the forest at present, interference with the management in future, and suggestion as to its removal.

\section{e. General Topography or Lay of Land and Drainage of the District.}

As it affects transportation, agricultural and other development and thereby future market, labor, and protection and the value of the property itself. This is generally not subject of personal inspection but is matter of maps and inquiry. Important here: General altitude as it affccts climate, agriculture, etc., best stated in per cent of total as: over $60 \%$ above 6,000 alt., etc.; topography, i. e., what per cent is steep lands, mountain slopes, not fit for farming; streams draining the dictrict, their value for driving timber, for water power, in some cases, for ordinary navigation; the stream valleys as natural lines of travel and railway construction. Swamp areas, areas of waste land and possibility or likelihood of reclamation. This means a brief statement of the great permanent conditions of the district which must always affect its development and are of importance to the particular property determining its value as a business.

\section{f. The Climate.}

Next to soil, and in many cases far more than soil, is the most important part of Site; it determines Species, it affects reproduction, growth, final size, and quality of timber. It also affects protection and exploitation or utilization and income and value of property.

I. Warm climate and long growing season produce a Loblolly Pine 24" diameter at forty years in Georgia; while a cold climate produces a 14 " Spruce at I50 years in the Adirondacks on better soil. The dry spring following the snow melt in the Lake Region and Ontario means a regular spring fire season; moist and even 
climate of the Southern Pinery has prevented any serious forest fires; the peculiar continental climate with its occasional dry years must always mean a special feature in fire protection; the deep snow fall of the Adirondacks or the North Rockies discourages pine and calls for Spruce or Balsam; the snow and ice road will always be a factor in logging in the North Countries, and absence of snow in the South will call for railway and wagon haul, etc.

2. In all cases the effect of climate on silviculture or the raising of the crop far outweighs all other considerations.

3. Usually the general climate of a district is known and much information can be secured from the weather bureau reports. What is wanted here is not long tabulations of relevant and irrelevant matter, but brief, preferably tabular statements to show exactly what the temperature, rainfall, frost, storm, etc., are for the district and point out in what way and to what degree these conditions affect silviculture, protection, exploitation, etc. Particular attention to length of growing season, temperature and precipitation during this period, frosts in spring and fall. Then also long dry spells, their regularity and effect on forest, especially on fire protection; storms, periodicity of these, direction and severity, regular storm roads as in the Gulf Region and in mountains.

4. In level country (Great Lakes, South) the information on general climate of district quite suffices, but in mountain country this is not true. Here every valley has its own peculiarities; the direction and intensity of wind changes with every slope; the rainfall around the Olympic Mountains in Washington, for instance, changes from over $160^{\prime \prime}$ on west sicle to about $3 \mathrm{O}^{\prime \prime}$ on Northeast side at Port Townsend all within the same National Forest.

5. It is evident that the Forester, in examining a property, can not possibly determine all these facts. But he can always get the general climate from the Weather Bureau, and he can usually gather considerable information from local people. Particularly on points of long dry spells, time of early snow, depth of snow fall, usual snow melt, character of spring season, etc. Here it is not a matter of accurate figures, but rather of experience upon which the people rely in their business affairs.

6. In addition the Forester may safely infer from the character of tree growth and other vegetation, from the presence of large burns, of parks, and grass lands, of sage brush slopes, etc., 
with regard to local climate in different parts of property itself. In recording it is well to state the basic facts, and leave the inference to follow. For instance if $10 \%$ of the property is steep north slopes, in latitudes north of $40^{\circ}$ the inference is safe that these slopes are dark, and cool or cold and relatively moist, etc. Similarly, the Spruce Slope in West Virginia, or in the Rockies warrants the inference that the climate here on these slopes is cool and moist; and south slope in Rockies, covered with sage-brush requires no meteorological investigation, the vegetation here tells the story more accurately than weather observations.

\section{g. Present Organization, and Expenses.}

Or Personnel maintained and necessary expenses incurred in connection with the care of the property in past years is usually known to the owner. Nevertheless it is helpful to state these facts and point out what portions of this personnel is replaced by a regular forest organization. It it also well to point out the insufficiency of present organization and consequent losses, or possible losses.

Usually there is an attorney in a nearby town to look after tax and trespass cases; a variable sum spent in cruiser services, etc., to look after, and more or less, protect the property. In many cases, as in the Adirondacks and the South, "caretakers" are employed to look after buildings, roads, etc., and usually these men are rather expensive, rarely efficient, and never concerned in the forest itself. It is not 11ncommon that the owner spends twice the salary of a good forester on a few men entirely devoid even of interest in the growing forest.

\section{LIST OF LANDS.}

The owner, or more often his local attorney usually lias a list of all the lands making up the property. Commonly this is in the form of :

a) Township plats with lands marked in color.

b) Tabular statement by township, range and section, and forty in United States survey lands or "Public Lands States."

Such a list and set of Plats should accompany any complete Report such as is here contemplated in connection with a Working Plan.

In addition to the mere "description", such a list should also 
indicate what part of the boundaries has been inspected and when, and the condition of these lines, blazes, and monuments.

In many cases certain areas or lines are in dispute; then also lands tinder timber contracts, etc., should be shown on plat and in list.

In many cases tinie of purchase, of regular land survey, title, etc., are of interest even in the matter of making a Working Plan.

In all cases where portions of the lands should be eliminated and sold for agricultural purposes, the lands should receive special color on the plat and note in list.

\section{DETAIL DESCRIPTION, NOTES AND MAPS.}

Aftcr all or any considerable part of the field work is done the field notes should te copied and one copy, at least, stored in fire proof vault.

The material. This is quite a bulky affair. For a forest of 50,000 acres, and if done by lots of eighty acres each and maps of every section, there are over 600 sheets of description and tally, and perhaps over ioo separate maps.

'Two ways now are open: Ordinary clerical help may copy, or clsc an expert, preferably the man in charge of the field work copies, studies and condenses. In the former case, it is safest to allow the clerk no change of data whatever, i. e., have it copied as it stands in the field notes, except the tally sheet where he can well substitute number for tally dots and lines.

Where the forester copies, the following will prove suitable.

a. Copy descriptions by Lots on same kind of sheets as used in the field, one sheet for one lot only.

b. Condense the descriptions for each Stib-Lot into one description per Sub-I,ot, i. e., where a Sub-L,ot in field receives two or more descriptions (common if well done), these descriptions are combined and averaged, and the volume of timber compited for entire Sub-Lot so that one line and one description suffices for each sub-lot. This requires expert knowledge, preferably personal knowledge of particular forest lands and it also requires interest and care, for in this task the first valuable record of the property is laid down.

c. 'These Lot sheets are then filed in regular order by Township and Section, or other systen. 


\section{COMPILATION OF THE INFORMATION IN A REPORT.}

I. View Point. Whether the property belongs to state, or to a man in New York the report must keep in mind two kinds of readers:

a. The Owner in New York or the Member of a state Commission ustially a non-technical and very busy man who cannot study a long report but is willing to spend a few hours to get the principal facts as they concern him. For this man a one or two page resumé is very helpful, but also the rest of the General Report should be in such form that, if he cares, he can readily find and understand the desirable information.

b. 'The Forester who is to use the Working Plan. He is. technical, critical, and for him the general Report should not only be brief and clear, but also quite complete, and it should refer to detail descriptions and notes and maps in such a way that he can readily verify all statements.

2. The Arrangement of the Material or the Form of the Report. Keeping in mind the custom of stating the more general facts first, it is usual to arrange the matter as follows:

a. Outside Conditions, or conditions not really part of the property. Here belong: Location, and description of District including lands and topography and climate; then also the population and its industries; the markets and transportation; also special forest industries, logging and milling, though these latter might well follow the description of the property.

b. Description of the Property, including I and and Timber, Improvements and Business. Tables are more telling than text, but long and complex tables, requiring extensive study, are rarely properly used.

3. The Compilation. The field maps are copied and compiled into larger maps on a smaller scale, and traced for white and blue prints. In compiling the forest descriptions and estimates or Tally Results it is well :

a. To decide first ${ }^{\circ}$ on the form and contents of the General Report. 
b. To make several separate tasks of the compilation. Thus to make one compilation for the data referring to the land or site; another to the merchantable timber; one to the age classes, to reproduction, to future treatment, etc.

c. To prepare a regular table for each of these tasks, following the field sheet, and adding colımns only where it saves time or adds clearness.

In this work, as in field work, it pays to use plenty of columns, and not try to have one column tell several facts. In taking off information from field sheets on these compilation tables it is well to add the data for each section. In this way the information is at once "bunched", as far as this is convenient by larger units. The same may well be done for each Township.

c. The Volume and Yield Tables are treated in the usual way, by condensing into general tables and diagrams.

d. For the notes regarding logging methods, markets, injuries, and then also climate, etc., no special directions can be given. They should be condensed to brief, clear and yet complete statements, and should never lose sight of the real purpose which they are to serve.

4. The General Report. This is a very important document. In most cases it is the first reasonably complete and fairly accurate statement regarding the property. Much depends on its form, size, style and arrangement. The best work in the field may fail to serve through bad compilation and unsatisfactory presentation in the General Report.

The following sample report does not pretend accuracy of detail, completeness or style. but is placed here merely to suggest how this kind of task may be done.

\section{A SAMPLE REPORT.}

Report on Forest property of John Doe, located in ....... County, Mich., comprising 50,000 acres.

I. Outside Conditions, or General Conditions of the District in which the property lies.

a. Lands and Topography. Level, gently rolling country. typical Michigan Pinery, I0-20\% swamp lands. Land covered with Glacial Drift, largely deep sands and loamy sands, the former Pine. the latter Hardwood and Hemlock lands: over $60 \%$ of all lands 
cut over-(logged) and mostly burned over. Numerous streams; with clear water, and moderate fall, some good waterpower; streams drivcable for soft woods, no regular navigation. Over $10 \%$ of land area in fine clear water lakes.

b. Climate, typical of North Michigan and Lake Region.

I. Temperature: Long severe winters, with much zero weather, short, but rather warm summers. Too cold, i. e., north of the natural limit of Hickory, Walnut, Chestnut, Sycamore, etc. ; too cold for corn as crop. Low temperature and short season result in slow growth, small amount of seed; affect sprouting of some of the hardwoods. On the pine land the sand heats up in summer to pcint of injury to seedlings.

2. Precipitation, about $30^{\prime \prime}$ per year; comes largely as snow. Dry springs produce a regular spring fire season. Summer commonly quite dry.

Extremely dry seasons at intervals of 6-10 years have caused great forest fires of which $187 \mathrm{I}, 188 \mathrm{I}, 1894,1907$ and 1908 are famous. In 1908 practically no rain from May to October. Snow deep and can be depended upon for sleigh hat1. Usually over 100 days of good sleighing. Covers seedlings; but deep wet snow breaks much timber, especially young pine.

3. Frost, especially late frosts, scvere and injurious to native forest trces. In 1907 and 1913 late May and June frosts killed new foliage on Oak, Aspen and even killed young pine. Frosts may occur in any month.

4. Prevailing winds West and Northwest and Southwest, the latter quite dry, often hot and injurious. Windfall not rare, accidental, i. e., no regular storm roads.

\section{c. Population and Industries.}

I. The population of county is about 7,000 and has been nearly stationary for ten years; the area is about 360,000 acres. Popuration mostly in three small towns; dependent upon the forest industries. A sparse rural population, likewise still depends largely on work in logging camps and mills.

2. Population is the usual American mixture, which gathers in forest districts; no colored or Indian settlements.

3. Sentiment favors agricultural settlement and clearing of lands and is kept alive by local papers, merchants, land dealers, etc. 
4. Labor is fairly plentiful, and quite efficient especially in woods work.

5. Timber trespass and carelessness with fire, in clearing. road-building, etc., still prevails and is not properly restrained by the authorities.

6. Taxation is high; twenty-one per Mill average for county. Increased settlement calls for roads and schools and may increase tax rate for near future.

7. Agricultural Development is slow, only i i $\%$ of county now improved land and only $3 \%$ has been added in ten years.

8. Mills: Three sawmills, capacity about $50 \mathrm{M}$. ft. per day are located in....... city, ....... and....... and employ...... men. Seventeen small "portables" also operate in county. Exploitation of Cedar and Hemlock Bark amounted to $\$ \ldots . .$. in past year.

Outlook: Two larger mills were moved away, and two small villages abandoned in past five years. Generally the local industries (except farming) are on the decline. Timber (as logs) goes out of county to ....... city where a closer utilization is possible.

9. Tourists, fishing and hunting partiès come into this county in considerable numbers. This affects protection but may also be made source of income.

\section{d. Markets and Transportation.}

I. Local Market. The mills, including the portables, then also agents of distant concerns come here as buyers and take practically everything including Jack Pine, and Tamarack, and even dead stubs of Pine and hardwood tops (cordwood cut in $4 \mathrm{ft}$. length.) The mills at .........city contract for logs of all kinds loaded on cars or delivered at track, and also contract for stumpage.

2. Prices at present are as follows:

Pine logs \$18.00 per M. ft.; stumpage, \$12.00.

Hemlock logs \$10.00 per M. ft.; stumpage, \$6.00. Etc.

3. Prices have advanced over $100 \%$ in fifteen years, and are rapidly advancing for all kinds of material. This "price growth" is estimated at $4 \%$ per year for Pine, Ash, Basswood, Elm and Cedar.

$5 \%$ for Hemlock and Maple.

$8 \%$ for Beech and Tamarack, and represents the most important growth on the property. 
a. Distant or General Market; chiefly Chicago and. Detroit. Mill run prices paid now for lumber f. o. b....... in this county:

Hemlock, \$16.00,

Maple, \$20.00. Etc.

Grading is not severe.

b. Freight rates to Chicago to Detroit to Buffalo, etc.

c. The X Railway passes through county N. and S., and has three branch lines aggregating........miles. Four branch lines abandoned in last ten years.

e. Logging in this district is now all to Ry.; and is both summer and winter logging; little machinery; few steam loaders; X Ry. furnishes cars.

a. Wages, average $\$ 35.00$ and board; good men hard to get for regular camps. Board costs 60 cts. per man and day.

b. Teams $\$ 500$. Keep $\$ 1.20$ per day.

c. Camps of boards; one concern uses camp cars.

d. Cutting $\log s \ldots \ldots \ldots \ldots \ldots \ldots .8$. 8 per M. ft.

Skidding per team ........... r.oo

Loading per team......................

Road building per team.......... 50

Railway construction .......... I. .

Railway operation and up-keep.... .75

Supervision ................ 25

Interest, tax, depreciation ....... .50 " " "

e. Hauling in summer by "Big Wheels"; in winter on sleigh, use ice road for haul over two miles; one outfit hauls twelve miles and uses sleigh locomotive, works day and night.

f. Logging is "clean" here now, i. e., all is cut; much of material does not pay for removal; logging destroys the forest, leaves slash. and is usually followed by fire.

$\mathrm{g}$. There is still about one billion feet of timber in this county and this is now being logged at rate of fifty million feet per year; about $30 \%$ Hemlock, $24 \%$ Maple, the rest Beech, Elm, etc.

h. Cedar and Tamarack is exploited entirely in small way by local people; ties cut and hewn at fifteen cents per tie, poles cut and peeled at thirty cents-seventy-five cents a piece, etc. Hemlock bark is peeled and stacked at \$I.5o per cord. 
i. The methods of logging are well suited to conditions; efforts at using machinery have not been a success. A closer utilization of hardwood tops has begun and will help fire protection where the forest is to stay.

\section{The Property.}

a. Area and form. The 50,000 acres are located in four townships, they comprise fifteen different pieces separated by numerous outside holdings, of which over $80 \%$ have been logged and burned over in last twenty years. The largest solid body is 5,600 acres, the smallest, eighty acres: most of the area is contiguous, i. e., the bodies "touch at corners."

b. Topography and climate are the same as for the county generally : it is a level and gently rolling country, with a few tracts of "pot hole" lands, and also a few small areas with rocky "hog backs."

The land is drained bv Wolf: Peaver and Deer Creeks, all following into the....... River: all drivable for soft timber. total length drivable streams forty miles.

c. The land is all covered with drift, the soil is sand and sandy loam, very little clay, and is generally over fifty feet deep. The land is classified by the timber it bears; the hardwood and Hemlock lands are generally considered farm lands in this district.. About $60 \%$ of these could well be farmed, of the pine lands not over 10\% and of the swamps not over ro\% would pay for drainage. About 2000 acres is open moss bog and mav be regarded as waste land at present. Classifying the lands from the stand point of growing timber, and using lay of land, size and appearance of timber, and yield per acre as principal standards we have:

TABLE OF SITES, i. e., Cood (I), Medium (II), and Poor (III) lands for growing the timber named.

\begin{tabular}{|c|c|c|c|c|c|c|c|c|c|c|c|c|c|}
\hline \multirow{2}{*}{$\begin{array}{l}\text { Types } \\
\text { of } \\
\text { Forest. }\end{array}$} & \multirow{2}{*}{$\begin{array}{l}\text { Total } \\
\text { Area } \\
\text { Acres }\end{array}$} & \multicolumn{3}{|c|}{$\begin{array}{c}\text { Site for } \\
\text { Norway Pine. } \\
\text { Acres. }\end{array}$} & \multicolumn{3}{|c|}{$\begin{array}{c}\text { Site for } \\
\text { White Pine. } \\
\text { Acres. }\end{array}$} & \multicolumn{3}{|c|}{$\begin{array}{l}\text { Site for } \\
\text { Hardwoods. } \\
\text { Acres. }\end{array}$} & \multicolumn{2}{|c|}{\begin{tabular}{|c|} 
Site for \\
Tamarack \\
Acres.
\end{tabular}} & \multirow{2}{*}{$\begin{array}{l}\text { Waste } \\
\text { I.and. } \\
\text { Acres. } \\
\text { Moss } \\
\text { Bog. }\end{array}$} \\
\hline & & I & 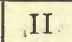 & $T$ & $\mathrm{I}$ & II & & 1 & $M T$ & II & $\mathrm{I}$ & II & \\
\hline Pine & & 4400 & $\overline{1020 ?}$ & 2900 & & & & & & & - & & $\longrightarrow$ \\
\hline $10 \mathrm{n}$ & 2 & & & & 11250 & 6750 & 4500 & 2203 & 9050 & I 125 & & & \\
\hline wamp lands & 10000 & - & - & 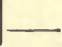 & & - & & & $\ldots$ & & 3000 & 5000 & 2000 \\
\hline
\end{tabular}


d. The Forest. Ahout half the area is covered by a stand of Hardwood and Hemlock from which some large White Pine was removed years ago: within this two distinct areas of sandy lands were covered with a fine stand of Norway and White Pine now largely cut and the land burned over. Over the entire tract are scattered fifteen more or less distinct areas of swamp lands. The following table describes these types.

a. Table of Forest Types.

\begin{tabular}{|c|c|c|c|c|c|c|}
\hline $\begin{array}{l}\text { Type of } \\
\text { Forest. }\end{array}$ & $\begin{array}{l}\text { Area. } \\
\text { Acres. }\end{array}$ & $\begin{array}{l}\% \text { of } \\
\text { Total. }\end{array}$ & $\begin{array}{c}\text { Virgin } \\
\text { woods } \\
\text { with merch. } \\
\text { material. } \\
\text { Acres. }\end{array}$ & $\begin{array}{l}\text { Areas not } \\
\text { cut but with } \\
\text { little or no } \\
\text { merch. stuff. } \\
\text { Acres. }\end{array}$ & $\begin{array}{c}\text { Cut and } \\
\text { largely } \\
\text { burned } \\
\text { over. } \\
\text { Acres. }\end{array}$ & $\begin{array}{c}\text { Waste } \\
\text { non- } \\
\text { forest. }\end{array}$ \\
\hline $\begin{array}{c}\text { Hardwood \& } \\
\text { Hemlock }\end{array}$ & 22500 & 45 & I 5000 & 5000 & 2500 & \\
\hline Pins & I 7500 & 35 & 5000 & 1000 & II 503 & - \\
\hline Swamp & 10000 & 20 & 4500 & 2003 & 1500 & 2000 \\
\hline Total & 50000 & 100 & 24500 & 8000 & I 5500 & 2000 \\
\hline
\end{tabular}

b. Amount, Quality and Present Value of Merchantable Timber on the Property.

\begin{tabular}{|c|c|c|c|c|c|}
\hline \multirow{2}{*}{$\begin{array}{l}\text { Forest } \\
\text { types. }\end{array}$} & \multirow{2}{*}{$\begin{array}{l}\text { Area. } \\
\text { on which } \\
\text { merch. } \\
\text { timber } \\
\text { occurs. } \\
\text { Acres. }\end{array}$} & \multirow{2}{*}{$\begin{array}{l}\text { Cut } \\
\text { per } \\
\text { acre. } \\
\text { M. ft. } \\
\text { b. m. }\end{array}$} & \multicolumn{2}{|c|}{ Value. } & \multirow{2}{*}{$\begin{array}{l}\text { Total } \\
\text { value } \\
\$ 1000\end{array}$} \\
\hline & & & $\begin{array}{l}\text { per } \\
\text { M. ft. } \\
\quad \$\end{array}$ & $\begin{array}{c}\text { per } \\
\text { acre. } \\
\$\end{array}$ & \\
\hline $\begin{array}{l}\text { Hardwood \& } \\
\text { Hemlock }\end{array}$ & I 5000 & 10 & 5.90 & 59 & 885 \\
\hline Pine & 5000 & 12 & 10.00 & 120 & 600 \\
\hline Swamp & 4500 & 8 & 3.75 & 30 & 165 \\
\hline Total & 24500 & & & 67.00 & 1650 \\
\hline
\end{tabular}


c. Amount, Quality and Value by Species.

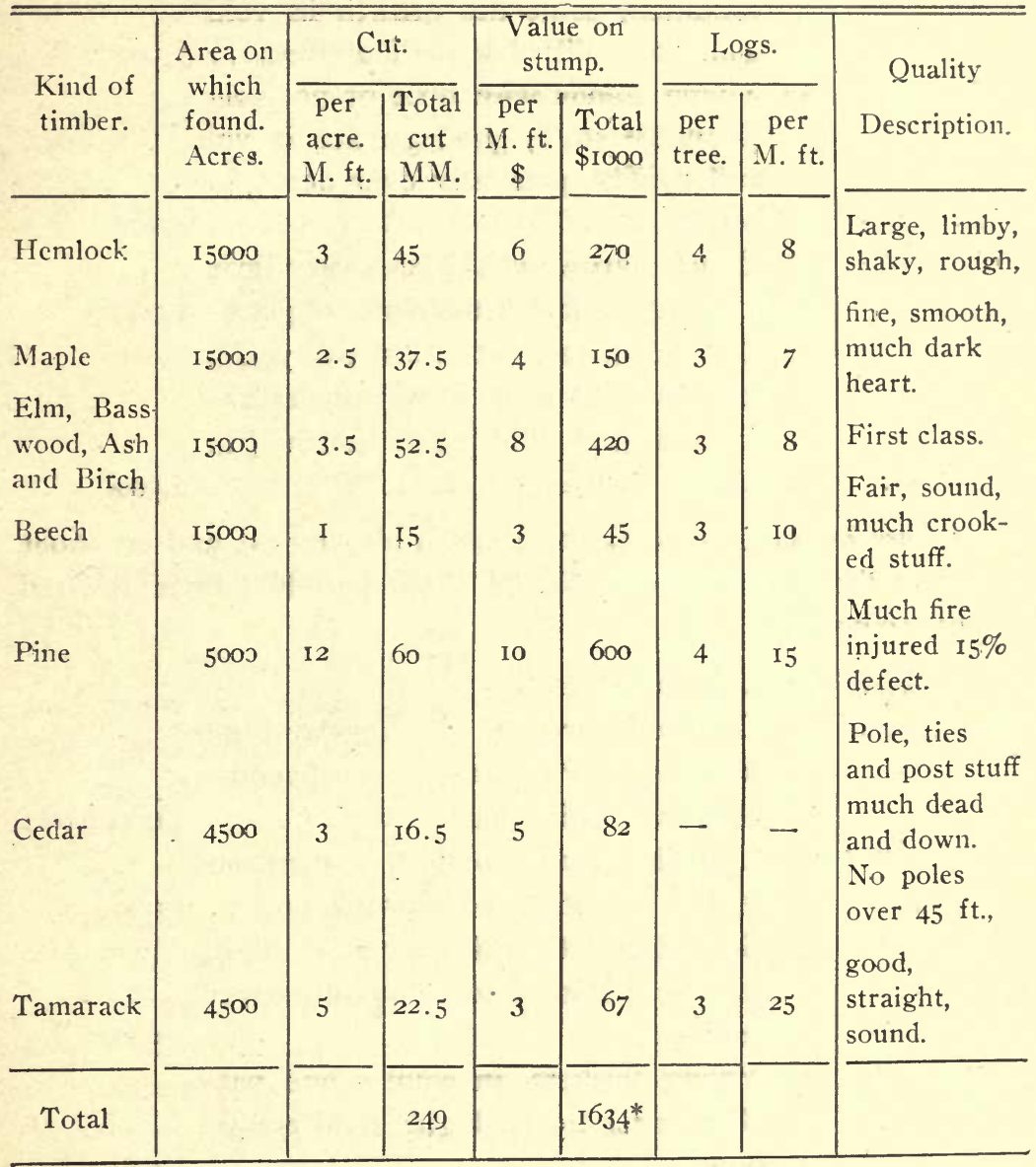

d. Condition of Timber in each Type by Classes of Stands found in each.

I) Hardwood and Hemlock Type, 22,500 acres.

"Stand class" I) Old timber, ("all old stands") defective, "going back", need cutting at once $\ldots \ldots \ldots \ldots \ldots \ldots \ldots \ldots \ldots \ldots \ldots \ldots$ acres

2) Old timber in good condition no middle age (size) stuff......... 5,000

* This discrepancy due to rounding off on several items. 
"Stand class" 3) Mixed-age ("all age") stands in good condition, some net growth in vol., more in quality (or size) of trees... 7,500

4) Young stands with little or no merchantable stuff; good growth in vol. and quality, generally over $25 \mathrm{ft}$. in height $\ldots \ldots \ldots \ldots \ldots \ldots \ldots \ldots$, 000

5) Young hardwood thickets, very little of young Hemlock, too dense in places $\mathrm{I}, \mathrm{OOO}$

6) Cut over areas, cut in last five years, some burned over, very little reproduction and this poor, much Pin Cherry brush ............. 2,500

A few hundred large White Pine in old stands; and on about 500 acres there is scattering White Pine reproduction in isolated clumps, doing well.

2) Pine Type, 17,500 acres.

"Stand class" I) Old fire-injured stands, Norway Pine So\% White Pine 20\%, no hardwoods, defective "going hack" ......... 4,000 acres

2) "All old" stuff, holding its own, no middle age stuff, no reproduction... I,000

3) Second growth stuff over $25 \mathrm{ft}$. high, in broken stands, does not fully cover

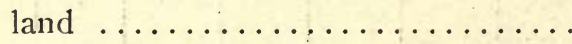

4) Young thickets, in clumps and patches under $25 \mathrm{ft}$. high; good condition $\ldots \ldots \ldots \ldots \ldots \ldots \ldots \ldots \ldots \ldots$

5) Cut over Pine lands, burned over repeatedly, about $25 \%$ with scattering Oak scrub, no reproduction, no growth of value at present ....... I I,500

3) Swamp Type, 10,000 Acres (incl. Moss bogs). "Stand class" I) Old, pure stands of Tamarack with very little Cedar and Spruce, hadly hurt by sawfly, rapidly decreasing in value 
"Stand class" 2) Old stands of Tamarack and Cedar, the latter predominant, good condition, no net growth in vol. or quality, some reproduction $\ldots \ldots \ldots \ldots \ldots, \mathrm{I}, 500$,

3) Young stands over $25 \mathrm{ft}$. high, but no merch. stuff, good condition as yet. Largely Tamarack hence in great danger ................. I, ", "

4) Young stands under $25 \mathrm{ft}$., same as under No. $3 \ldots \ldots \ldots \ldots \ldots \ldots$........ I,000

5) Cut over areas, cut during last five years, fair reproduction ........ I,500 "

6) Moss $\mathrm{kog}$, with few Black Spruce, not forest .............. 2,000

f. Estimated Growth in Vol. and Quality of timber on property.

I) Areas with negative growth, timber deteriorating, worst in Tamarack, next in Hardwoods, least in Pine; deterioration estimated at $5 \% \ldots \ldots \ldots \ldots$ ro, 500 acres

2) No deterioration, no growth in Volume or Quality ..................... 8,000

3) Iittle growth at present, reproduction hardly set in, and much of this poor quality.......... I 5,000

4) Good growth in volume and quality, mostly in young stuff, partly too dense, Tamarack in danger of sawfly .................... 6,500

Only about $\mathrm{r} / 3$ of land actually has a net growth of timber in Volume or Quality.

\section{g. Growth of Timber in Value.}

From previous statements, prices have advanced rapidly for last fifteen years, most in last ten years, and they are expected to advance at:

$4 \%$ per year for Pine, E.lm, Basswood, Ash and Cedar.

$5 \%$ for Hemlock and Maple.

$8 \%$ for Beech and Tamarack.

This growth in Price will generally balance decay or deterioration in Hardwood, Hemlock and Pine, but in Tamarack situation entirely uncertain and acute. 
TABLe of VAlue Growth per Yrar.

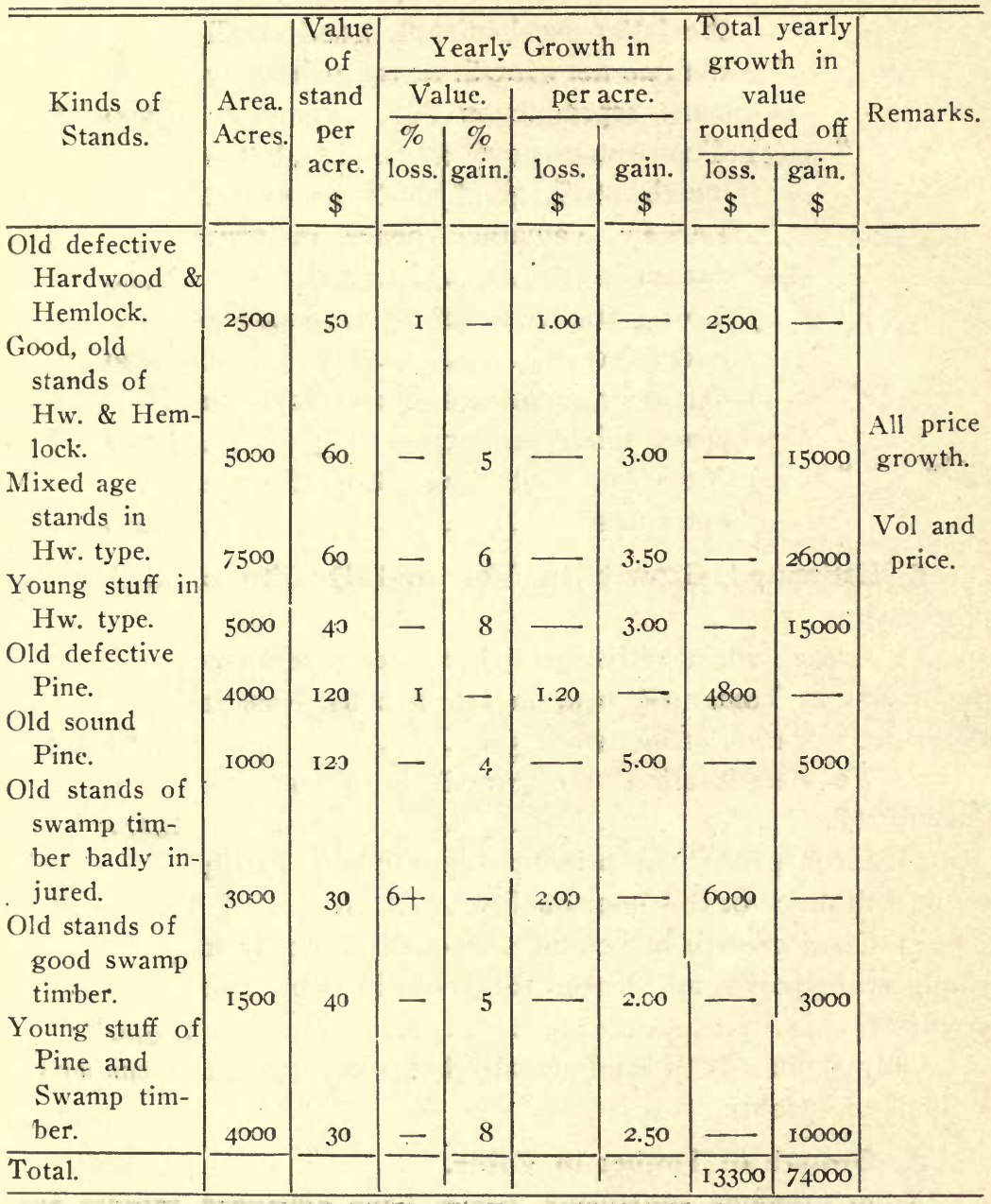

This estimate indicates a probable net growth of about $\$ 60,000$ per year in value of this timber, the principal growth consisting, not of growth in the forest but of price growth, in market value of timber.

\section{h. Volume Tables for Principal Species.}

A few diagrams and brief tables showing the size, (D. H. and vol. and value) of tree at age of $40,60,80$ and 100 years. The complete tables are filed with Detail Description Material. 
i. Yield Tables. Treatment similar to $h$, the volume and value per acre at $40,60,80$ and ioo years.

j. Injuries and Dangers.

I. Fires have burned over:

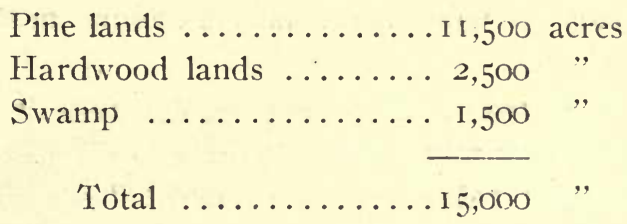

On the swamp lands good reproduction is coming; on the hardwoods there is some reproduction but of poor quality; on the pine lands, it is mere Oak scrub and useless Aspen, which does not grow to value here.

Fires run most on pine land, little in swamps, except in specially dry seasons, when swamp fires may be the very worst.

Fire season: After snow melt, on pine lands, soil dries and warms up rapidly and fires start in this district every year.

Fire causes: Clearing land; Railways (along........branch) also campers, fishermen, tourists and berry-pickers.

Help in fire work is quite easy to get and efficient.

Cooperation: Association now organizing; arrangement with local people practical and promising of good results.

Fire patrol needed: Ordinary years not over two months in year. Special years, May-October; perhaps once in ten years.

"Look outs" indicated especially on Pine land areas.

Fire lines needed in Pine lands.

2. Insects: Sawfly has injured over half of all Tamarack. Insects also work on Pine land areas, injuring young stuff, even Jack Pine.

3. Late Frosts severe until end of May, some years in June; kill back new foliage on native trees.

4. Heavy wet snows break down young timber, notably Pine, every year on this property.

5. Ice on trees is a common trouble and destroys much timber and opens up Crowns to disease. 
6. Wind storms have caused several large windfalls in Sect... and Sect.....; they are rare, accidental, i. e., there is no regular storm road here.

7. Diseases of trees have caused large amount of defect, in all kinds of timber; but the matter is no worse than may be expected in all old stands of wild woods and therefore needs no special consideration.

8. 'Timber trespass is a common trouble here, it will continue and even be worse as more people come into the district. Only a regular organization, patrol, etc., will prevent this loss.

\section{k. Timber Contracts, and Rights of Way.}

Two contracts exist for timber:

I. J. D. has contract for all Hemlock in Sections ....... The contract runs for twenty years and ends 1922. Price $\$ 3.00$ per M. ft., bark thrown in. No limits as to area, he can come back over any area if he likes. This contract means that J. D. has a right to cut and exploit all over this area until I922; and while his work has not been worse than that of others, it does:

Break down hardwood timber not ready to be cut.

Leave, in places, large masses of Hemlock tops.

Keep people in the woods during summer peeling bark, and in fact, at all times. These people need watching.

Prevent any proper treatment of these lands.

Would recommend one of the following:

Buy off J. D. outright. He has still standing here about ten million feet and it is worth to him about $\$ 5.00$ per M. ft. As he pays only $\$ 3.00$, an offer of $\$ 2.00$ per $\mathrm{M}$. ft. may tempt him.

Follow J. D. with a logging job and reduce the loss through his wprk. In this case it is worth at least $\$ 1500$ to get some compromise which will make J. D. work the land over according to some definite plan, agreed upon, and also to contract, not to return to any lands once cut over.

2. X. Smith has a contract for the Cedar in Sect....... The contract runs for ten vears, ends I@I 5 , prices:

Poles: size $25 \mathrm{ft} . \ldots \ldots \ldots$

size $30 \mathrm{ft} . . . . . .$. , etc.

Ties etc. 
No restrictions, no re-arrangement of prices. Little is to be said or done about this Contract; it was a mistake financially, the stuff is worth twice what he pays for it.

3. The J. \& R. Co. have right of way for their Logging Railway through Sect......., about ten miles in all; they paid for all timber cut, but were not compelled to clear up brush. They banked all tops on both sides of right of way right into edge of timber. Also, they make no effort at fire protection by spark arresters or patrol. This should be remedied and arrangements for this should be made with the Company. It is worth $\$ 2000$ to the property to get this done.

I. Expenses and Present Organization used in taking care of the Property.

I. Taxes. Assessment at full value (by law) is as follows: Hardwood and Hemlock timber. I 5000 acres at \$15-\$225,000 Pine timber ............ 5000 acres at 30- 150,000 Swamp timber .........4. 4000 acres at $5-20,000$ Cut over lands ..........26000 acres at $2-\frac{52,000}{\$ 477,000}$

Tax rate 2 I per Iooo $\therefore$ Taxes total $\$ 9387$.

Assessments are still on increase, and even the rate may increase considerably, as it is now up to 35 per Mill in some parts of the county. The average tax rate for county is $2 \mathrm{I}$ per Mill, for the State 17 per Mill. The State has not begun to consider a rational system of forest taxation but is expected to do so in near future. The preferred form as at present discussed is the flat rate on soil, together with a ro\% stumpage tax at time of cutting.

2. Other expenses, yearly:

a. Local attorney as agent, retainer per year.......\$2000 Looks after timber contracts, tax affairs, trespass, and engages cruiser, etc., to examine lands at times.

b. Cruisers and others engaged as needed, average for three years ....................... 2000

c. Improvements: Cottage at lake, roads and trail average per year .......................... 2500

d. Trespass suits and incidentals, average cost per year. 600 
3. A proper forest organization can save expenses a, b \& d, and also prevent future losses by fire and avoidable timber deterioration (by prompt and well planned cutting). The loss by fire in the three years (since present ownership began) have been small, but ${ }^{\circ}$ may be expected in any dry year to mount up to $\$ 10,000-\$ 20,000$ in a single year. The loss by deterioration and unused land is great and amounts to more than the entire expense of a forest organization.

Notes with regard to the foregoing Sample Report.

1. There is no effort at exact Age Classes. This seemed unnecessary since the field data in this forest, especially the Hardwood type make the Age Class work largely a rough estimate or a matter of mere size.

2. Matters of Improvement and Business were left out, and the subjects of Volume and Yield Tables merely indicated.

3. Similarly the nature of the case prevented many kinds of interesting forest affairs and conditions from appearing here, notably: Turpentine Industry as it exists in the South; Grazing as practiced and important in the West; Fish and Game affairs as they exist in Europe and also in some of our Eastern forest properties. The manner of treatment of these may be inferred from the foregoing; the principles are the same; each is treated in its relation to the Business (Income and Expense), Utilization and assurance of future supply, iricluding its effect on Silviculture and especially Protection. 


\section{PART III. PLANS.}

\section{GENERAL PLANS.}

\section{A. GENERAL CONSIDERATIONS.}

a. General Plans and Detail Plans together form the Working Plan proper. Reports tell the owner what he has, Plans tell him what he can do.

b. The General Plan usually applies to the entire forest or property ("Revier" in Germ.), the Detail Plans for Protection, for Improvements, for Planting, etc., also apply to the entire forest, but Detail Plans for Regulation of the Cut in Amount and Location, and consequent Regulation of Age Classes do not always apply to the entire forest, since each Working Section receives a separate Plan. Where a forest is small and uniform in Site and Stands, the cntire forest may have but one plan. But even the General Plan in its directions as to Species, Silviculture, Rotation, takes up the matter by Working Sections. Large forests, such as some of our National Forests will require special treatment, and may better be divided into several parts, like so many distinct properties, each with its distinct General and Detail Plans.

c. 'The property, the Forest, composed of land and timber, is assumed to te used for the purpose of raising timber and the plans must tell what should be done to make the best possible use of this property.

But the purpose is not always the same. A forest in Wyoming may be as valuable for its grazing possibilities as for timber; in Wisconsin it may be merely a matter of raising timber; in the pinery of Alabama it would certainly also be used to produce Naval Stores; while in Maine or Washington the waterpowers, tourist tusiness and hunting and fishing opportunities might outweigh the 
raising of timber in importance. Accordingly, even the General Plan for the forest is not always the same, but varies with locality.

d. The General Plan as well as Detail Plans are not fixed affairs, but change with time and development. In Germany the plan of Protection may be omitted entirely because protection here is old, and there is nothing to be modified. In the United States, on the other hand, the plan of Protection may be and often is the first and most important plan to make and develop.

e. The distinction between General and Detail Plans is not sharp and consistent. In Montana the Grazing Plan would be important and deserve a place in Ceneral as well as in the Detail Plans; in Michigan grazing, if allowed at all, would be a trivial matter and form part of the Detail Plans of Secondary Utilization.

f. General Plans deal with all large and important features of the enterprise. They sum up briefly dominant conditions; outline methods to he used, and the object to be attained.

Usually they cover:

I. The objects of the forest-business, or the objects of the owner in buying the forest and conducting this business.

2. Species, or Kinds of timber which the forest is to raise.

3. Methods of Silviculture, or methods to be employed in raising the crop of timber.

4. Rotation, or how old the crop of timber is to be when cut.

5. Regulation of the Cut in Amount and in Location, condition of Age Classes, distribution of young and old stands on the property and a plan for greater regularity in Age Classes and more satisfactory distribution.

The above five topics usually make up General Plans in textbooks treating of the old settled conditions of the. state forests abroad. In a new country like ours, and wherever new enterprises are to be developed, several additional lines of work require attention in these General Plans. Among these are:

6. Plans of Improvements, particularly the development of roads, trails, telephone lines, suitable housing for help, etc.

7. Plans of Utilization, or plans of logging timber, policies and regulations in cases of timber sales on stump, and then also plans for secondary utilization, such as grazing, turpentine, tan bark, etc. 
8. Plans of Protection, chiefly fire-protection. Risk, danger points or areas, danger-months or periods, proper patrol, most effective improvements, the organization of extra help, and cooperation.

9. Estimates and Apportionment of Income and Expenses together with a statement of Personnel or help.

Where parts of the lands are used for water power sites, tourists' camps, etc., a definite policy or Ceneral Plan for these enterprises should be worked out, but this is no longer within the sphere of forestry proper, and therefore need not be considered here.

\section{B. THE OBJECTS OF MANAGEMENT.}

What do we keep and develop the property for?

a. In Central Europe the object is, generally, to raise crops of timber most demanded in the market. This applies to over $90 \%$ of all woods: Apparently this is the desire of the owner, and is made much of in the books. But in reality it is more a matter of conditions than of desire. In a number of States the law compels the owner to stay in the business of forestry and do it reasonably well. Even where he has the liberty to clear land, he must chose between forestry or clearing. In the latter case he ceases to be of interest in this connection. Where he stays in forestry, it is good business, site and market which determine for him the limited choice. In mountains the climate forbids raising Oak, etc., on the sands of North Germany the site compels him to use Pine.

b. In our own country the same will be true. While a farmer in the Ohio Valley may raise a variety of timber, practice Coppice and Selection Method, etc., the owner of larger forests rarely has a like range of choice. In the Northern Spruce region it is generally Spruce or scrub hardwoods; Spruce alone pays and the choice of the owner has little play (provided it is to be a forest and not mere game park, etc.). On the sands of the Lake Region and South, in the Lodge Pole forests of the Rockies, in much of the Yellow Pine, and in all Alpine woods of the West, the Site decides, and the owner has merely choice of forestry or not forestry. He may be penurious and fail to provide funds for protection, etc., it is true, but this will 
readily lead to devastation and ruin, and the ownership will change. The desire of the owner is also limited by market. The owner may desire to cut Lodgepole at sixty years of age, but if it takes I 50 years to get a railway tie, and ties are the smallest stuff his market can take, the desire of the owner is of little consequence.

c. In the United States at the present time woods are held in a great variety of ownership and conditions of market, transportation, etc., so that the immediate object of holding timber at present varies from that of the small lumberman who buys stumpage for immediate cutting to that of the National Government in its permanent policy with regard to large holdings in National Forests. In the one case there is no thought of forestry, not even protection, the forest is merely a mass of logs on the stump; in the other it is modern forestry, good protection and well planned utilization and silviculture.

In the former case no plan is made, none wanted; in the latter case we find great activity in perfecting knowledge concerning the forest, constant planning and a prompt adaptation and modification to meet new requirements and to use new information. Numerous intermediate cases or conditions exist, and for that reason we make and will make for many years to come, a variety of Working Plans, which will differ as to completeness and emphasis. Some of these will be little more than Plans of Protection (chiefly against fire), others will lay stress on utilization, while still others will introduce improvements and the beginnings of Silviculture.

The following cases of ownership affecting present objects of holding timber appear of interest in the United States now:

I. Woodlot of the farm. If this is permanent at all, the object is to produce a home supply of fuel and other timber. In New England and the South, larger woodlots produce for general market and approach regular forests. Usually land is relatively good, market and convenience of getting out material are of the best, and there should te a good return from the soil. A plan for the most intensive form of forestry is justified for this class of important forest lands.

2. Forests of the Lumberman Owner: vary from those of the small owner of stumpage to be cut at once, to the holdings of 
supplies for thirty and more years. In the past, the plan of handling the forest consisted in directions for most economical exploitation. To this has been added in last fifteen years, plans for protection by individual effort and cooperative enterprise, and in a few cases even plans for a systematic cutting of timber, at least foreshadowing a Regulation of the Cut and also some form of silviculture. The policy or Object. with this class of Properties is rapidly undergoing changes in direction of real forestry.

3. Forests of Pulp and Paper Companies. Here large investment stimulates effort to prolong the supply of timber, and the fact that smaller sizes can be used to good advantage and that a variety of species (especially of conifers) is used, facilitates this effort. Nevertheless these people have preferred thus far to lag behind; opportunity is of the best and should be evident to anyone. Here, intensive forestry, especially planting and clear cutting on lands that will grow timber rapidly, is indicated.

4. Miscellaneous Holdings of large tracts of forest such as the game preserves and parks in the Adirondacks and the East and South, holdings of Water Companies, etc., etc. Here the forest is secondary, it is kept for beauty, shelter of game, or for protection of the purity of the water supply. Usually the object is to keep the forest with as little expense as possible, and generally these tracts are left, rather in the hands of a non-technical "Caretaker" than to a competent forester. The matter of income and expense and assured protection should decide these owners to prepare Working Plans and to practice rather intensive forestry.

5. Railway Companies in the United States have been and are now among the largest owners of forest. Most of their large holdings came to them as Land Grants from United States Government to induce railway construction. A few of these companies have begun to employ foresters, most of them prefer to sell their holdings, usually to lumber companies. In many cases the holdings consist of inferior lands, practically waste lands, as in Pennsylvania, etc., and of small bodies of lands held in connection with right of way and about stations. These Companies then:

a. Hold for market large bodies of Virgin forest. Here, efforts, if any, are limited to protection and to disposals of land and timber, leasing of grazing lands, etc. 
b. Hold waste lands; on some of these an effort at reforestation has been made.

c. Small patches of ground along their right of way and about stations. On these patches the effort is to beautify, to please the traveling public.

During the last ten years a few of these companies have begunto realize the danger of a shortage in railway ties, and are preparing to meet this by going into forestry, buying suitahle lands to provide stumpage and by proper care, raise new supplies. Here is a field for the most intensive form of forestry, but as yet the object itself is still under debate, so that a real Plan in most cases does not yet exist.

6. State Forests. These vary from virgin forest such as parts of the Adirondack holdings, through all gradations of culled and cut over woods to the most desolate cut and burned-over sand plains of the Lake Region. Since the whole subject of state forestry has not yet hegun to be a real business enterprise, but is still matter of debate, with practically no recognition in the legislatures of the several states involved, there is neither policy nor appropriation, in fact not even good will, and the object of holding these forests is, therefore, an uncertain one, and can only be inferred from the efforts of those interested in the work itself and from the little work actually done.

The small holdings in the New England States were set aside or acquired for the sake of saving the beauty or scenery, protect streams, and help as object lessons to the people.

The state forests of New York ostensibly were for scenery and water preservation; in fact they would never have been bought and certainly never have been held, had it not been for the wealthy owners of summer homes in the mountains. The object here does not consider the forest a crop, nothing is cut, millions of feet annually, green and dead stuff, are allowed to go to waste. The work so far consists in a half-hearted protection and show place planting, there is no forestry, no lumbering, merely a holding of $\mathrm{I} / 2$ million acres of wild woods in a state of Nature. Forestry here is still forkidden by law.

Pennsylvania owns nearly a million acres of largely devastated mountain woods or lands and is buying more; she educates her 
own foresters at Mt. Alto; and proposes to practice forestry. Her laws are good and adequate. But in spite of the excellent efforts of those interested, and those directing the work, the State has not yet begun to treat the matter seriously in any particular beyond permitting and encouraging the practice of forestry. The appropriations and the force of men is not $20 \%$ of what it should be, if these State lands are to be converted into useful and valuable State Forests, and while the object is clearly stated in law, the legislature has not yet recognized the magnitude and importance of the enterprise.

Michigan, for decades, had a fine opportunity of gathering up cut over lands, swamp lands, etc. For years she advertised six million acres as tax lands. But up to I9I 3 these lands were sold at nominal prices. What there is left today as "State Forests" is primarily areas of poor sandy lands, cut- and burned-over repeatedly, until they present far more a problem of waste land reforestation than the management of State Forests. In keeping with past policies, the object of holding these lands today is still uncertain.

Wisconsin, like Michigan, continued in the same policies of land disposal until 1905. Since then certain areas have been definitely set aside as State forests; the policy of selling has been replaced by one of buying lands; forestry is attempted, laws are adequate and all that is lacking, is proper support and appropriation.

These few cases suffice to show that with our State Forests, the object of holding and the policy of management of the lands set aside for State Forests is still in the formative stage. The subject of State Forestry is by far the most important one before the people of the United States. The value of State Forests is established in Europe; the object there, in most states, is :

a. To assure a home supply of timber.

b. To assure the continued kest use of large areas of poor lands, of mountain country, sand plains, etc.

c. To safeguard proper water distribution.

d. To maintain the beauty of the land.

e. To derive an income from these properties for the good of the people. 
7. National Forests. The object as expressed in the original laws was to protect and preserve the forest and affect the water distribution in the mountains of the West. Today the object has taken the form of a well defined policy closely patterned after that of State forests of Europe. This policy has been put into practice and the National Forest Service today is the only organization in the United States practicing Forestry in the most approved, up-todate manner. It has gathered $90 \%$ and more of all needed forest information and has developed Working Plans, notably in the direction of Forest Protection, unequalled anywhere. But the National Forests cover a large range of country, with great diversity of climate, topography, market, etc. In keeping, the objects of management vary for different forests. On the Angeles in Southern California where a chaparral is all that has been able to maintain itself as cover, the object is one of protection of this cover, though its value is only in water regulation and not in timber. On the Targhee where a high mountain country is covered with tracts of Lodge Pole and areas of grass lands, a proper protection and use of both of these is the object, and the forester becomes interested in Range problems as well as silviculture and logging. On the Snoqualmie protection and utilization of the great mass of standing timber and proper silviculture or method of cutting the old and growing a new crop of timber where old stands are removed is the object of management and the forester here, like the forester of Germany, is first and last a timber farmer.

\section{CHOICE OF SPECIES.}

Right choice of crop is important on the farm, and ten times more so in the forest, where acorns planted today make a forest to be harvested in 200 years hence.

a. In most cases, where we begin with wild woods, the species on the ground are kept. But even here there is often a choice as to which to favor, and which to suppress or eliminate. In the Sprtice and hardwood forests of New Fngland and the Adirondacks the Spruce is the most valuable tree and is favored; the same is true of White and Norway Pine in the Irake Region, Longleaf, Loblolly and 
Shortleaf of the South, Red Fir in Washington (West Side), Yellow Pine in Idaho and Montana.

b. In many cases site, climate, soil and drainage dictate. A cold Tamarack Swamp leaves little choice, and the same is true of Jack Pine Sands; and Alpine districts in the Rockies and Pacific countries call for Spruce, Balsam and mountain Hemlock.

Where the site is good, as on good hardwood lands in the Ohio Valley and South, the forester is largely directed by what is wanted, by owner and market, and may raise anything from a Catalpa fence post to White Oak saw and veneer timber.

c. Where a mixed stand is desired, relative behavior of the trees asserts itself. Spruce and Oak mixtures have proven failures in Germany, and even Spruce and Beech needs watching wherever the Spruce feels at home.

d. Where bare lands. are to be reforested, the question often arises as to the value of native as against foreign species or species from distant localities. Where no experiments are permissible the native tree deserves preference. But the prevalent fear of "exotics" is largely unfounded and based more on theory than practice. Red Fir in Germany has done well, so has White Pine, Black Locust and Red Oak. Norway Spruce does well even in warm and dry situations in Southern Michigan, and White Pine has made good groves on the plains.

e. Even under the old settled conditions of Central Europe this matter of Species is still a problem, receiving much attention and discussion. Some serious mistakes were made in the past. For instance, 20-40 years ago, Scotch Pine was planted extensively in parts of the Black Forest, where the heavy snows break down entire stands of these Pine poles, and give the present forester no end of trouble. Replacement of Beech by Spruce and other conifers is in progress on account of better incomes. Then also change from pure forests to mixed forests is being agitated.

f. On large properties especially in mountain country this choice of species needs careful attention; different parts of the forest require different species, and selection must conform to site and market, and provide not so much for the immediate but rather the distant future, and on all poorer lands the upkeep of site is foremost. In the United States and Europe Market calls primarily for 
conifers and this may be expected to continue. Occasionally a local market demands special materials, wagon stock, cooperage stuff, mining timber, pulp and acid wood, poles, piling, fence posts and even fuel; but such markets frequently lack permanence to justify stocking large areas with the particular stuff desired.

g. To keep up the fertility of the land much can be done in the selection of Species. Generally hardwoods are better soil preservers than conifers; tolerant kinds like Beech and Maple are better than intolerant trees like Oak, Poplar, Birch, etc. On the poor sands where only Pine makes a satisfactory crop, underplanting with Beech, etc., alone has been able to keep up fertility enough to enable the Pine to hold out to an age of roo years and make acceptable sizes. It is primarily from this stand point that atle authorities like Gayer insisted on the return to mixed forest in Germany.

h. Over millions of acres of forest lands in the United States the combination of Site (land and climate) and market allow but little choice. Spruce will predominate in the cold Northeast: hard Pine in the Southern Pinery; pine in the Lake States; Yellow Pine and Lodge Pole in the Rockies, with White Pine and Larch in the Northern Rockies. Yellow Pine dominates the dry east side of Sierra and Cascades; mixed Conifers the west side, and here Yellow Pine and Sugar Pine and Balsams in California; Red Fir, Hemlock, Balsam, Cedar and Spruce on West Side of Oregon and Washington. High altitudes call for Spruce, Balsam, Alpine Hemlock and White Bark Pine, while our Tamarack Swamps call for 'Tamarack. Cedar and Black Spruce.

\section{METHODS OF SILVICULTURE.}

\section{a. Principal Methods of Silviculture.}

As distinguished by the great silviculturist Lorey may briefly be outlined as follows:

\section{The Selection Method.}

"Plenter betrieb", "Femelbetrieb”, Lorey.

Composition: Pure or Mixed. 
Age of trees on any one acre: old, middle age and young, i. e., "many" or "all age" stands.

Rotation, or age at which ripe timber is cut: Determined by size, i. e., diameter linit.

Cutting: Stand is cut over every ten or twenty years, i. e., the Period of Return is ten, or twenty years.

The cut takes out large or ripe timber (harvest).

It takes--defective or poor timber (improvement cut).

It takes out thinnings, and also provides for or stimulates reproduction.

The cut rarely takes over $1 / 4$ of total volume of stand and puts woods in shape for next ten or twenty years.

Reproduction: 'This is natural Reproduction from seed; in hardwoods also from sprouts (Basswood, etc.).

Result: A Selection Forest where trees of all ages and sizes occupy the same forty-acre lot, and furnish a great variety of sizes at any time from a small area.

Advantage: Kceps a forest cover, protects young stuff against sun, wind and frost; protects soil against drying out and erosion. It gives a variety of sizes on a small area of land; and reproduces itself without expense.

Disadvantages: Costs more to log; much injury to young stuff by logging: produces less timber; is irregular and difficult to control and therefore apt to be overcut or undercut.

Applicability: To all species and sites, it merely follows nature's methods. For good business it should be restricted to tolerant species and especially mixed forest.

In Use or Operation: Probably the oldest method, formerly much used abroad; today $7 \%$ of all German forests are Selection Forests, and only about $2 \%$ of State Forest are in this form.

In the United States this method is used in the woodlot and of late has been introduced in parts of National forests. It is the proper method in all rough mountain country, in "protective' forest, and is well suited for a beginning in forestry in most of our large wild woods districts. It is nature's method in our forests of hardwoods, and mixed stands, but is not the natural form everywhere, as is often claimed. In forests of intolerants, pure stands of hard 
Pines, 'Tamarack, etc., the even aged stands predominate and nature's method is a form of "clear-cutting" with seed trees, and "seeding from the side."

\section{Shelterwood Method.}

"Schirmschlagbetrieb" of Gayer and of Lorey and in part Lorey's "Femelschlagbetrieb."

Composition: Pure and Mixed.

Age of trees in any stand: Even Aged, i. e., trees are nearly enough the same age, so that the small difference is not apparent in older stands.

Rotation: a definite period, ripe timber is cut at some given age and not merely when of some particular size.

Cutting, or Method of Procedure: For illustration:

a. Cut out about one-third of stand, preferably largest trees, to open up entire stand and admit more light. Then wait for seed year.

b. After seeding, take out another one-third of stand to make room and light for seedlings, and leave the last one-third of stand as an even shelter to protect seedlings against sun, wind, and frost and also to hinder a rapid development of weeds and brush.

c. When Reproduction is well started and no longer in need of shelter, but rather in need of light, the last one-third of the ripe timber is removed.

In practice the method varies; it may use only one seed year, or several, it may take off the stand in two cuts or in six cuts; it may take only six years (as in Pine) or forty years as in Balsam and Beech in Baden; it may rely entirely on natural reproduction, or it may normally employ artificial help as in Beech forests of Denmark.

Reproduction, normally is natural, and takes place before the old stand is entirely removed.

Results: Ordinarily an even aged stand where trees differ only 5-Io years in age; but in the "slow" forms the stand is not even aged and resembles the Selection Forest; trees vary from 30-40 years in age.

Advantages: Combines the good qualities of Selection with those of all methods leading to an even age stand. Protects Site and reproduction; it enables careful control, assures better care in 
thinning, raises better and more timber, than the Selection forest; and it gives better utilization of site during the period of reproduction than does the Clear Cutting system, where the land is not properly utilized for a period of several years.

Disadvantages: Danger from blowdown of last part of old stand. More costly logging, danger of costly delays when seeding fails; expensive artificial reproduction, where much is done to correct failures; with intolerant species is added great loss of reproduction for lack of light, or else a cover of the land by weeds and brambles.

Applicability: It is claimed by its advocates to apply to practically all species. In actual practice in Germany it is generally a failure and has been abandoned except in Beech and Balsam. From this it is safe to say that it can well be employed in tolerant hardwoods and conifers. Spruce often fails by this method in pure forest, but works well if mixed with hardwoods.

In Use: An old method developed in Beech forests. Today in use chiefly in Beech and Balsam, very little in Spruce, Pine and Oak. About $12 \%$ of all German Forests is Beech timber forest, and about $2 \%$ is Balsam, and these $14 \%$ are practically all handled under this system. Both of these trees require shelter in the first few years. In Lnited States practically unknown, and certainly never in regular practice. Well suited to mixed hardwoods and hardwoods with Spruce and Hemlock. Spruce alone cannot stand this method on account of blow down, unless the stand is reproduced, very slowly, and is not in exposed positions:

\section{Clear Cutting with Natural Reproduction.}

Part of Iorey's "Kahlschlagbetrieb" and of Gayer's "Saumschlaghetrieb." Including the "Seed 'Tree" methods introduced in United States.

Composition: Practically always pure forest, with a little of other species "blown in" accidentally.

Age of Stand: Generally even aged; depending on success of seeding.

Rotation: A definite period; but timber must be old enough to seed abundantly. 
Cutting: Ripe timber is cut clear, normally in strips. Where west winds prevail, strips run North and South and work starts on the east side of any stand. Best authorities prescribe narrow strips, not over 100 yards wide.

Reproduction: 'The strip of land cleared of timber is seeded from the side, i. e., we do not expect seedlings under the stand or trees, but away from the stand or trees, on open, cleared land.

Result: An even age stand made up of kinds from which the seed is derived, generally one species, or pure stand.

Advantage: Cheap logging, cheap reproduction, simple, even age stand.

Disadvantage: Bare land exposed to sun and wind covers with brambles and weeds, dries out and thus hinders reproduction. The seeding is rarely satisfactory, and if it must be helped artificially, is costly.

Applicable: Only used in timber with light seed, chiefly in pine and other conifers, also Aspen, Birch, etc. With us in I.oblolly, Jack Pine, Shortleaf, also in Tamarack and Cedar Swamp, Lodge Pole, Red Fir, etc.

In Use: Formerly this method was much used in North Germany in Pinery (on sands), and then modified in various ways (Coulissenschläge" of the Germans). Today very little is done with this method in Crermany, and it is not recommended by best authorities (see Borggreve "Holzzucht", p. I85, etc., and especially p. 200, and see also Reuss, Gayer, Weise, Ney of later authors).

This method has been.modified as follows: The lumberman either unable under the particular conditions, or unwilling to cut timber in small bodies, demanded that he be allowed to log off the land in large bodies, up to several thousand acres. To assure some reproduction of Pine (the usual species) and to give to young growth the benefit of plenty of light, and, in most cases, to appease the lumberman who was unwilling even to leave a reasonable portion of old timber, a few trees per acre were left as seed trees, as few as one tree per acre have been recommended and as little as $5 \%$ of ripe stuff was insisted upon and secured. Since these lone seed trees in most cases were left on relatively large areas, it was clearly a case of Clear Cutting with seed trees to seed from the side. In some cases (Lodgepole) lone trees promptly were thrown by wind 
and the method was further modified. Groups of trees, blocks of an acre or more in size were left; then also the old method of "Coulissen" was revived in places. In United States all this is experimental as yet.

In the last few years there has been further development, a larger and larger number of trees are left, until this "seed tree method" is transforming into a form of open Selection method or a form near the "Zweihiebiger Hochwald", as described by Weise in his Waldbau. To call this Shelterwoods seems a misnomer, for it lacks the two principal elements: Shelter for seedlings and working to even age stand, the object being primarily to suit present conditions of market, and avoid large areas of clear-cut lands.

This method of rapidly clearing the land of old timber and developing even aged stands appears to have been nature's way in most of our pineries, Tamarack swamps, and large parts of the forests of Red Fir.

Unintentionally this method has been used in Loblolly to such an extent as to lead to the name of Old Field Pine.

Large areas of burns have covered themselves with Jack Pine, I.odgepole, Red Fir, and Tamarack, indicating the suitability of this method in United States.

\section{Clear Cutting with Artificial Reproduction.}

Composition: A mixed stand is feasible, but in practice the stand is pure.

Age: Strictly even aged.

Rotation: A definite age is adhered to.

Cutting: The entire stand is cut clear.

Reproduction: By sowing seed (even cones) or by planting young trees 2-5 years old, raised in nurseries; costs $\$ 5-\$ 20$ per acre, and normally succeeds perfectly.

Result: An even age, usually pure stand.

Advantage: I and does not lie idle for years, waiting for nature to seed it: if five-year transplants are used there is a gain of at least several years over seeding from the side, and this may mean as much as \$15-\$20 per acre. I.ogging is cheap; in many localities in Germany the money saved by not having to skid logs and wood to the roadway (the common way) will suffice to plant the area 3-5 
times with good transplants. Produces largest return per acre in volume, quality and therefore in income, allows best care in thinning by a proper spacing at the start.

Disadvantages: Leaves the land without a cover for several years (while trees small) and exposed to sun and wind. This is of little consequence on all better lands, as the cover, when once established, stays for sixty and more years.

The cost, even though not large, is not justified in very cold, rough mountain lands, remote and unprofitable under any condition; but is justified under any ordinary conditions such as exist today in nearly all parts of eastern United States and Europe. It leads to pure forest. This claim is not necessarily true, but in practice this condition has been established. How far this is injurious we are not certain as yet, except that large areas of one species suffer greatly when insect calamities arise.

Applicability: German experience indicates that Pine, Spruce. Larch, Red Fir and Oak are best raised by this method; Beech and Balsam do not thrive without shelter while young and are not raised on clear cut areas. Generally it is safe to say that this method succeeds with all but a few sensitive species which require protection in the first few years.

In actual Use: This method has displaced all others from a large portion of the German, Swiss, etc., forests. It has proven simplest, safest and most profitable and all effort and preaching to induce the forester to return to a mixed forest with natural reproduction has not had any appreciable effect.

In United States this method has been started and is rapidly making progress, East and West alike. It is the only hope for at least one-half of our cut- and burned-over lands in the Great Lakes Region, Pennsylvania and the South.

'These four fundamental methods of the regular "timber forest" have been and are modified a great deal in ordinary practice. In the Selection Forest artificial reproduction is often employed; the same is true of the Shelterwood and regularly in the method of Seeding from the Side. The Shelterwood Method, as stated, may drag out the process of reproduction over forty and more years and approach the Selection Method; or it may cut everything in two 
cuts within ten years, and approach Clear Cutting with a mixture of natural and artificial reproduction.

Then also any method may be employed on a large area, or a small one; on areas in the shape of strips or circles, (groups, spots and patches) scattered over the forest. But whether the area on which we cut clear is a regular forty-acre tract, or a number of small, say three-acre tracts, scattered over a few forty acres, has nothing to do with the method itself; it is still Clear Cutting with natural or artificial reproduction as the case may be. Unfortunately a great deal of coining of names has been done in this connection so that Mayr in his Waldbau enumerates sixty-four different methods of treatment where in reality only about half a dozen methods exist and receive slightly different application to suit particular conditions. That the many names coined for real, or only supposed, variations merely lead to confusion and not to clearness and better 11nderstanding has already been dcmonstrated in the United States as well as abroad.

\section{The Coppice Method.}

German "Niederwald."

Composition: Usually hardwoods, pure and mixed. In United States so far chiefly Oak and Chestnut; (Red Wood in California) I.ocust, Catalpa, etc.

Age: Even aged.

Rotation: I 5-40 years.

Cutting: Cut clear, with axe, and cut slanting stump and close to the ground.

Reproduction: From sprouts, at times may need a little help by planting.

Result: Coppice woods, even age stands, generally small timber, cordwood and poles, even tie size: also tan bark.

Advantage: Cheap logging, simple to handle; regular, little subject to windfall, etc. Small capital, inexpensive.

Disadvantage: Needs fair land; mild climate; can use only hardwoods (except Redwood) ; raises only small stuff not demanded by big market. Small income has resulted in gradual degeneration of French coppice. 
Applicable: On good land, mild climate, with home or local market for small stuff of hardwoods.

In Use: In about $7 \%$ of all German Forests; only i $\%$ of all state forests in Germany; extensively used in France and the Mediterranean countries. In United States woodlots; formerly, in Maryland, Pennsylvania, etc., in regular way for iron works, now largely abandoned. The large forests of United States and North Europe are generally conifers, on rather poor lands and little suited to coppice.

\section{The Standard Coppice.}

"Mittlewald" of the Germans.

Composition: Pure or mixed; the Coppice is of hardwoods. and usually also the "standards", but this is not necessarily so.

Age of any Stand: Coppice is even aged.

The Standards vary in age by multiples of the rotation of the Coppice. If the rotation of the Coppice is twenty years, and the Coppice growth on any one acre is fifteen years old, then the Standards are:

I 5 years, 35 years, 55 years, 75 years, etc., old. This regularity in actual practice rarely exists.

Rotation: Coppice with short rotation, i 5-30. Standards with long rotation, 60-20n.

Reproduction: Coppice, and artificial, usually planting of large plants for standards.

Results: An uneven stand, often resembling, in practice, a wild woods, old and young stuff on every acre. Raises cheap coppice stuff as well as large, but usually limby timber.

Advantages: I,ike Coppice, except that large stuff is also produced.

Disadvantages: All those of Coppice, except that it produces also larger stuff, but, in addition, is very complex and difficult to handle. Little control, little order, a regular "gardener's" job.

In Use: Formerly much used in all good hardwood districts of Cermany and France. Rapidly giving way to simpler methods. usually Shelterwood. 
In United States never systematically practiced; some of the woodlots present conditions and appearance of a regular Standard Coppice. Outside of the woodlot there is no place for this method in United States.

\section{b. What Method to Use.}

I. In the beginning stages of forestry in our wildwoods it is rarely possible to introduce at once the method best suited to Species and Site, and it will be necessary for many years to come, to compromise between that which should be done and that which can be done under given conditions. Nevertheless, it is well at this point to warn against too great stress on given conditions, for the most important of these, transportation and market, are changing so rapidly that it is a great mistake to contract and otherwise plan for long periods ahead on the assumption that things remain as they are. This is being realized of late, and most of our timber contracts no longer run for indefinite terms on conditions rigidly fixed at the outset.

2. In large areas or properties of Wildwoods we commonly meet the following three conditions affecting the choice of Silvicultural Method:

a. There is no net growth; decay and growth balance. This is not always true; it is more true in our Hardwoods and Hemlock of the Lake Region than in the Pinery; it is more true in a large area of Southern Pine than in the Pineries of the Rockies, etc. But it is always near enough true to urge immediate removal of the old, defective stands, the stands "going back", etc. The first demand then is to cut the property over for old and defective timber to start or to increase net growth on the land.

b. Logging in the wildwoods where all roads and other improvements must be made, and generally also, must be paid for out of the proceeds of the first cut, requires that large contiguous areas may be logged together. But good forestry in Clear Cutting as well as in Shelterwood system demands small cutting areas. There is but one compromise and this is the Selection Method where enough is taken to warrant logging and enough is left to assure safety and welfare of the forest. 
c. Our forests still lack proper protection and will for a long time to come. For this reason large areas of reproduction ( 1000 acres and more) of. Pine and other conifers in solid bodies are very unsafe affairs and should be avoided. We may expect some serious calamities in this direction.

Keeping in mind these three points, it would seem clear that in most of our large forest properties the aim should be in the first cutting over: To Leave a Forest, to let reproduction come in slowly, under protection and in interrupted areas, groups and patches and so avoid especially the great fire risks.

3. In districts where stumpage is now valuable, market and transportation good, and growth satisfactory, there is no good reason why more intensive work should not be done. In many areas of this kind it will be far better to clean off the old stand entirely and restock by planting, where best species and proper spacing can be assured. Generally it may be said that wherever stumpage is \$IO.O0 and over and where inferior material can be removed at cost or at some profit, and also where growth per acre and year may be set at $75 \mathrm{cu}$. ft. of wood, it will now pay to cut clear and plant. These conditions exist today in a large part of the eastern United States and are rapidly extending everywhere.

\section{c. Illustrations from Different Forest Regions.}

The following statements are not intended as directions but rather as illustrations of what is under consideration. In every larger region conditions vary and the most intensive as well as the most extensive systems are indicated in practically every forested state in the Union.

I. The Woodlot of the Farm in the eastern half of the United States. Here the land is usually fair, even good, it is valuable, a large return should therefore he demanded. Labor is ample, market of the best, usually the farm home takes a large part of all that grows, and requires this right along. Work normally starts with a mismanaged, badly over-cut tract, often grazed, with little reproduction and poor growth. A first cutting over in several years time removes old and defective trees. This should be followed by planting or seeding if necessary to start a satisfactory stand. After that 
the Selection method or Standard Coppice will furnish goot results in all of our hardwoods. In Conifers cut clear by strips and replant at once: mix in few hardwoods to better the soil. Ordinary coppice works well in hardwoods of the Fast and South but in the States west of the Alleghanys tends to poor dried out scrubwoods, except in moist situations.

2. Spruce Forests of the Northeast. These are mounitain woods varying from pure Spruce to hardwoods with a mere sprinkling of Spruce. On lower slopes and in valleys, not farmed, (or farmed formerly and now abandoned) a milder climate produces forests of hardwood, Hemlock and White Pine. 'The sites vary from good valley and bench lands and lower slopes with a fair depth of soil, to steep and high slopes with thin rocky land. The climate is cold, winters long, snowy, frosts late, summers cool and short; precipitation ample, specially dry years (fire danger) occur at intervals of ro-20 years and have led to bad forest fires. In keeping with cold climate, growth is generally slow (except on good valley lands), small timber logged today is generally over I50 years old; cut per acre generally less than io $\mathrm{M}$. $\mathrm{ft}$.; size of timber rarely over $2 \mathrm{O}^{\prime \prime}$ and over $100 \mathrm{ft}$. But the ample humidity of climate of this region makes reproduction easy and assured; not only White Pine, but also Spruce readily seed up abandoned pasture lands: On higher mountains there is a scrubby forest, which should never be cleared. but held as protective cover. Market along all railways, good, proximity to Boston and New York should make them of the best. But so far transportation facilities have been deficient, railway construction being costly, only Spruce and Pine could be logged and driven down the various streams, while hardwoods in many places have remained practically valueless. This is rapidly changing. Logging is costly in keeping with small timber, light cut, and bad topography. 'The Selection method is best suited to all upper slopes and rough lands and should come often enough (every I 5-20 years) to take out timber in small quantities, and leave a fairly dense cover on account of windfall. Spruce should be favored, but hardwoods should not be entirely cut out for reason of soil and beauty. On rench lands, etc., Clear Cutting and planting of White Pine (and Norway Spruce?) has already proven a success. 
3. Appalachian Mountain Region from Pennsylvania South. L.ow mountain region, mild climate, at lower elevations; great variety of topography and soils; valleys settled to farms; rain fall over $4 \mathrm{O}^{\prime \prime}$ and steep slopes lead to much injury from erosion where forest is cut clear, this injury is especially bad in the deep soil districts from Virginia southward. Forests of hardwoods, generally mixed with hard Pine, and farther up with Hemlock; at higher altitudes and in north half of district, White Pine on, north slopes of West Virginia, etc., Spruce forest. Lumbering old, and forests largely cut clear in north half, in south half lumbering now at its best, clear cutting the rule. Logging expensive especially in south half; no snow, steep ground; much rocky land, long ridges; requires railway; and these are costly. Market excellent, plenty of industries; large cities near, and matter chiefly one of transportation. Growth and reproduction in keeping with climate, generally fair to good, except on very poor soils. Rapid development of this region, excellent sites and proximity to great cities call for intensive methods as far as soil and topography permit. Wherever there is great danger from erosion, and also on the poor, rocky sites the Selection method alone is justified; Coppice in small areas serves to hold soil and furnishes good timber (Chestnut and Oak). On easy slopes, benches, etc., with sufficient soil, the system should be suited to species, and for conifers Clear Cutting and artificial reproduction, doing away with all delay and uncertainties is justified unless insects should prove too serious a menace. In this case mixed forest in Selection method or Shelterwood is most efficient.

4. Southern Pinery, Great sandy Plains with rich narrow river bottoms and extensive swamps; warm climate, (cotton belt) heavy rainfall, plenty of rain all through the long growing season. Growth rapid, reproduction easy and safe. Forest homogeneous pure pine woods. Market and transportation good now ; proximity to sea and to large eastern cities, and ease of railway construction promise to make market as good as exists in any forest region. Considerable agricultural development. I.ogging simple and cheap. Market and Site call for intensive methods. Pine site generally now worth over $\$ 20.00$ per acre to raise timber on a $3 \%$ basis. The sandy soils call for Pine in pure forest, even age stands, and justify Clear Cutting 
with artificial reproduction, and short Rotations. Plenty of rain makes natural seeding in open Shelterwood stands possible in Longleaf as well as Shortleaf and I,oblolly, and clear cutting with seeding from side will probably succeed better in Loblolly and Shortleaf than with any other species and in any other region in the United States.

River bottoms and swamps should be developed agriculturally.

5. Pinery of the Lake Region. A large district of level country, with numerous drivable streams, excellent transportation facilities by Great I,akes and many railways. Region covered with glacial drift, soils deep, generally sand, or loams and gravels. Norway and White Pine on sands (Jack Pine on the poorest), Hardwoods and Hemlock on loams and better sands of Wisconsin and eastward. Swamps and lakes scattered over entire region; swamps stocked with Tamarack, some Cedar and Spruce. Winters cold and snowy, spring dry, growing season short, severe spring frosts; specially dry seasons every 8-I 5 years have led to great forest fires. Growth and reproduction fair; an 18 " White Pine produced in 100 years ; clear cut lands dry out, "brush up" and restock with difficulty; Hemlock does not reproduce at all under these conditions. Market good now, \$IO-\$20 on stump for Pine, growing better rapidly; logging efficient and cheap. Market and Sites call for intensive methods. Except in swamps and specially poor sands or rocky-thinsoil lands Clear Cutting with artificial reproduction should restore a truly valuable stand. In Hardwoods the Selection system may be used as a starter, should take out the large and poor trees and leave at least half the stand on the ground. On moist sites Shelterwood is practical in Maple and Beech woods, but will not make the returns which can be secured by a clear cut with artificial reproduction in which Spruce and White Pine replace the greater part of the hardwoods. Tamarack and Cedar in the swamps restock readily by seeding from the side, but in larger Cedar stands a Selection method is preferable as it prevents rank growth of swamp "brush." Jack Pine with Clear Cutting and seeding from sides, in narrow strips should he kept until these lands have recovered from the effects of burning, and after that Norway Pine (also Scotch Pine) shotild replace Jack Pine. 
6. Western Yellow Pine Districts. 'These Western Pineries occupy the dry, warm, lower slopes of the Rockies, the east side of Sierras and Cascades and the dryer slopes of the west side of the ranges from Middle Oregon South. Topography and soil vary within wide limits; the soil, being dry, is generally fertile and it is the warmth and dryness of climate (and soil) which give these sites to Pine. Hard-baking "adobe" soils in Arizonz; coarse granite sands and gravels on the east side and limestone soils on the west side of the Black Hills and pumice sands in parts of the Cascades indicate variety in this direction. Forest varies from open, parklike stands of pure pine woods to rather dense and brushy mixed stands of Yellow Pine and Red Fir, with Balsam and Larch in Idaho, or Yellow Pine, Sugar Pine, Balsam and Cedar in California. Tendency, as in all hard pines, to even age stands. Reproduction varies chiefly with moisture conditions and is precarious in most parts of Arizona and New Mexico, easy on the granite in the Black Hills, much more difficult on the limestone, etc. An $18^{\prime \prime}$ tree requires over 150 years in the drier parts of district (Arizona), only about 100 years in the moister portions (parts of Oregon and California). Topography varies from perfectly level and easy rolling plateau country in Arizona, South Dakota to steepest mountain lands. Market just developing, transportation to long distance markets (Chicago, Kansas City, etc.) costly. Logging very variable, easy on plateau, difficult in mountains where it calls for chutes or slides, etc. : high cost of labor enters heavily. Protection against fire a serious problem, summers generally dry ; specially dry seasons recur at intervals $10-20$ years: great fires 1902 , I910, et. Barkbeetle a serious menace to the "all old" stands.

So far several methods have been tried. The lumberman has generally cut clear, taking all he could use. The Government has tried Clear Cutting with seed trees or seeding from side; and various modifications of this method in the direction of ordinary Selection method. Generally this latter method is best :

a. 'To avoid exposure of large areas to sun and wind and thereby rendering difficult, if not impossible, the natural reproduction desired.

b. To avoid large contiguous bodies of young growth until some later period when fire protection is ample. 
c. To cnable present development where the market is unable to use everything and also to work over small, detached areas.

d. To encourage early removal of large masses of defective and dying stuff.

Since dryness of climate is everywhere the serious difficulty in Western Yellow Pine forests, introduction and care of Balsam, Cedar, Red Fir and Hardwoods which tend to give more density to forest and thereby better protection from drying winds is advisable in spite of the lesser value of these species as timber.

Where artificial reproduction is necessary to re-stock larger areas of clear cut lands it is best done by planting of good stock, spaced not less than ten feet, and planted with sufficient care to. assure success. Rodents are a serious obstacle to natural and artificial reproduction of Western Yellow Pine.

7. Lodge Pole Pinery. 'These forests are of importance in the higher slopes of the Rockies from Colorado north, and also in the northern Cascades, as well as out-lying mountains like the Big Horns. The Sites are inferior; a cold climate and short growing season make slow growth. It requires generally over Ioo years to make a $12^{\prime \prime}$ tree, and 150 years to grow a crop of tie timber. The sites vary in topography and soil; large areas are plateau country with ample depth and quality of soil; the altitude assures reasonable moisture conditions and encourages reproduction. This takes place readily on clear cut and even burned-over lands, less readily within the stands. Fxceptionally dry seasons and prevalence of electric storms have led to great conflagrations in Lodgepole: large areas are bare, and generally stands of pine are even aged. At the lower limits Lodgepole merges into Yellow Pine, and then is often mixed with Red Fir; above, it grades into the Alpine forests of Spruce in the Rockies, or Balsam, Hemlock and White Bark Pine in the Pacific Ranges.

The market for Lodgepole is generally a local one; it is, therefore, developed only in a few places located near large mining enterprises, Montana, Colorado, Utah, or convenient to railways (the timber) as in the Big Horns and along the U. P. Ry. in Wyoming and N. P. Ry. in Montana. Logging here is regular mountain work, as a rule, calls for chutes, flumes and other special devices 
Slow growth, size and quality of timber, remote location, little market, costly logging, difficulties of labor situation in such remote districts, then also the importance of this Pinery as "protection forest", all call for Selection method, at least in the beginning work. Leave a forest.

After this pinery is sufficiently developed as to Utilization and Protection, so that small bodies of timber may be removed economically, the Clear Cutting system may be employed, as better suited to this decidedly intolerant species. So far Clear Cutting with seed trees in various modifications has been employed. Of late this method has been replaced, at least in part, by a Selection method with more or less compromise to enable profitable utilization.

Artificial re-stocking of these lands is hindered especially by rodents, and has not been found an easy matter. If it were not for these animals, an old time sowing of cones should succeed on Lodgepole burns.

8. Hemlock and Balsam Forest on the West Slopes of the Cascades, notably in Washington. Large mountain slopes, with fairly deep coarse soils, heavy precipitation; deep snowfall; remarkatlc snow melts leading to destructive floods. Good growth, ready reproduction and tolerant species all combine to make these idea! stands for valuable Selection forest. Danger from erosion alone calls for a method which keeps a constant cover on these slopes. Abundant waterpower and forest make a good combination; and proximity to ocean will soon make market conditions such that the lest care of the forest will be justified. .

9. Forest of Red Fir in Washington and Oregon. Iarge bodies of giant timber, "all old", often broken stands where Red Fir, Hemlock, Spruce, Cedar and Balsam occur in all forms of mixture as to species, age, and condition; also large areas of young stands from ro-roo years on former burns. Sites vary as to topography and soil, from level to the roughest, from deep soil to rock masses, but over the entire area a mild humid climate assures rapid growth and excellent reproduction. On good ground a growth more than twice that observed in Michigan forests is nothing uncommon. The real home of Red Fir, which grows to great size (200 ft.) and age ( 400 years) and produces yields of over Ioo M. ft. 
per acre and is exceptionally free from insects and disease, and at the same time makes material most in demand by the market. Choice of Silvicultural method is dominated by preference for this species. Since Hemlock is far more tolerant and readily takes possession of the ground even under a good stand of Red Fir, Selection or Shelterwood are not well suited here, unless Hemlock is wanted as mixture. With a prospect of excellent market within twenty-five years proximity to sea, excellent growth and easy reproduction, there is no reason why Clear Cutting with planting should not be recommended.

The foregoing sketches will indicate the view point and some of the conditions which enter into the matter of choice of Silvicultural Method to be cmployed in any given case. It is clear that no general lines can be laid down which may be applied without modification, and every case needs special study.

In this connection it may be stated that large areas of cut-over lands, usually turned over repeatedly and deteriorated through soil wash, exposure to sun and wind, and now occupied by useless brush, should be planted without delay. The enterprise is a gigantic one; it is peculiar in that it does not lend itself readily to ordinary private enterprise. A man of small means cannot wait fifty years for the crop; the men of large means do not want to wait. The local township and even the local county is too poor to do this work. So it remains for the State and Nation. And particularly to the State should fall this task, and all lands not well suited to agriculture should be bought up and promptly converted into State Forests by planting. Such an enterprise would be most profitable for any State to undertake, it would assure local supplies of timber, stinulate wood-working industries, regulate water flow, help the appearance of the district and would make millions of acres produce the only crop which is an assured success upon these lands. The attitude of indifference in this connection will cost vast sums in the future. To get some measure of what is needed here it may be said that a State like Pennsylvania could well own $20 \%$ of its land area in State Forest, and that it should spend at least \$1.00 per acre in care of this and before long (in the life of a state) would have a net income of $\$ 3.00$ per acre from these forests. 


\section{E. ROTATION.}

In Central Europe timber is cut at an age varying from twelve years in Coppice to 200 years in Oak for timber. Where regular timber (saw timber, etc.) is raised in Germany it is generally cut at the age of :

Pine and Spruce 80-100 years, (60-80 years in private forests).

Balsam

Beech

Oak

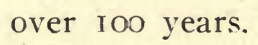

Rotation has been shortened during the past roo years especially in Conifers. Reason for this lies chiefly in market and in the introduction of rational methods of forest valuation. German market for saw timber today prefers timber $1 \mathrm{O}^{\prime \prime}-\mathrm{I} 5^{\prime \prime} \mathrm{d}$. b. h. to larger or smaller, and the best sizes are $\mathrm{II}^{\prime \prime}-13^{\prime \prime}$, requiring about $70-90$ years in dense forest.

The matter of Rotation is of great importance in Germany today in spite of the old settled conditions of forest and market. It forms one of the important topics in forestry literature, and the Bavarian government has recently established a special commission to ascertain proper Rotation for different forests species and sites.

In the United States this matter is rapidly coming to the foreground. The preliminary regulation for National forests requires establishment of Rotation. Recent studies of White Pine, Loblolly, etc., attempt to work out the age when it is most profitable to cut the crops of timber to be established.*

The Kinds of Rotation usually distinguished are:

\section{a. Technical Rotation.}

Which allows the timber to grow to a certain size, needed for a particular use, such as pulp wood, fence posts, railway ties, telephone poles and piling, saw timber, etc. This condition of size dominates our present market and through this the utilization of timber.

* See Bull. i I (new series) igr4, U. S. Dept. Agri.

Sterrett: "Forest Management of Loblolly Pine." 
I. In Loblolly or in Lodge Pole enterprises for hewn railway ties the diameters preferred are $12^{\prime \prime}, 13^{\prime \prime}$, and $14^{\prime \prime}$. If this is the only use for which the timber is grown, and we get as many ties from the $14^{\prime \prime}$ tree as from the $I 7^{\prime \prime}$, it is obviously useless to allow the tree to grow to $16^{\prime \prime}$ and waste time and use of land for perhaps twenty years (Lodge Pole) or more. This case, especially in slow growing Lodge Pole, illustrates the importance of careful determination of Rotation. If a stand of I odgepole produces practically as many satisfactory ties at 150 years as at 180 years, to leave this material the extra thirty years would be a loss which, in large operations, would run into a considerable sum. On the other hand, if $I_{50}$ years are required to produce tie timber, then it is useless to discuss shorter Rotations unless it is reasonably certain that other uses may be expected to change the market.

This also illustrates the uncertainty in this determination of Rotation, especially in new countries where market is rapidly changing its requirements and prices.

2. Generally the upper limit is less rigidly fixed, larger timber means a greater number of uses, but the lower limit is fixed.

In spite of all the changes of the past roo years, a few fundamental facts remain valid today. The consideration of a few principal uses may illustrate this:

a. Fuel wood, though used in enormous quantities must be cheap and have local market; it competes with coal, is almost excluded from many districts, does not pay for long distance transportation (unless by water); can be supplied from thinnings, etc. Fiven fifty years ago it was a factor in Forest Regulation, called for a Rotation of maximum volume, and was regularly transported especially by water to larger towns of Europe. Today it has generally disappeared from consideration of the rotation.

b. Pulp wood requires reasonable proximity of, usually, large and costly mills; it favors conifers and of these the Spruce. So far it pays well, competes with lumber in purchase of stumpage. The use of other species is growing, and like fuel wood, pulp wood may largely be cut from thinnings in the future.

So far Pulp wood has not attained an importance to control Rotations, but has affected the practice of thinning, and indirectly it is leading in the direction of shorter rotations. In the United 
States pulpwood may soon call for special forests with a practice and Rotation calculated to produce largest volume of well cleaned material. A sixty. year Rotation for planted Spruce is indicated in the Northeast. With exhaustion of cheap cooperage and veneer material and with increase of cheap power by stream development, pulp board will increase in importance and be able to utilize cheap woods and refuse-materials in large quantities.

c. Railway ties, telephone poles, piling, wagon stock, and other similar timber requiring sizes over $10^{\prime \prime} \mathrm{d}$. b. h. compete with saw timber for stumpage except that species like Cypress, Cedar, Hardwoods can be used, not commonly desired for lumber in these smaller sizes. Generally $1 \mathrm{o}^{\prime \prime} \mathrm{d}$. b. h. inside bark is the lower limit and whatever time is required to produce this size will remain the minimum rotation for this important class of materials. The fact that rough, limby and crooked material can be used here will affect the rotation but little, for an adequate yield per acre demands a fair cover of trees in which light is fully utilized and growth therefore slower than scen in shade trees and park stands. Ties cut in the United States today vary widely in age. For Lodgepole over ${ }_{5} 50$ years; same for White Cedar (Michigan, etc.) ; over sixty years for Oak, only 30-40 for Loblolly.

d. Ordinary Saw timber prefers conifers to hardwoods, at present in ratio of three to one; demands fairly clean and straight material, prefers even grained and slow grown stuff and does not go below Io" d. b. h. inside bark. The few special cases (box boards with us to. $8^{\prime \prime}$ ) do not alter this materially. Europe has probably reached the smallest practicable limit in its present market demands. Smaller sizes mean increased waste in sawing, poorer product, and they also mean waste in the forest by taking stuff at a period of rapid growth.

If this is true then, the time to grow a tree $I 2^{\prime \prime} \mathrm{d} . \mathrm{b}$. h. outside bark is the minimum Rotation in saw timber, and this size must be produced in good form, fairly clean of limbs, and preferably with an even and fine grain. Saw timber cut in the United States today gives but little information on this point. Generally it is larger and much older than is needed. The giant stuff of Redwood and Red Fir, Sitka Spruce and Cedar on Coast is generally over 250 years old, much of it over 300 ; the same is true of Cypress in the South: 
Sugar Pine, Western Yellow Pine, Hemlock and I,ongleaf as cut for lumber today are generally over 200 years old; White Pine, Spruce, Lodgepole and Cedar, also Oak, Yellow Poplar, Maple and Beech, over 150 years old, and the rest of saw material generally over 100 years.

Using $12^{\prime \prime}$ d. b. h. as minimum size, measurements thus far made would indicate for ordinary sites a technical Rotation:

Of forty years and less (down to twenty-five years) for Cottonwood, Red Gum, Eucalyptus, Red Wood from sprout, also for Maple, E.lm and other timber on good soils like river bottoms, etc.

Of $40-60$ years for:

White Ash, Red Oak, Chestnut, Elm, Basswood, Cuban and Loblolly Pine, and the following Pacific Coast trees, Red Fir, Hemlock, Spruce, Sugar and Western Yellow Pine.

Of $60-80$ years for:

Norway Pine, Eastern and Western White Pine, Longleaf and Shortleaf Pines of the South, Cypress, Red Fir of the Rockies, Hickory, and Yellow Poplar.

Of $80-100$ years for:

White Oaks and Western Balsams and Cedars in the mountains.

Of IOO- 120 years for:

Maple, Beech, Yellow Birch of Great Lakes Region and East, Eastern Hemlock.

Of $120-150$ years for:

Red Spruce, Tamarack, Lodge Pole and Engelman Spruce of the Rockies.

These figures are mere suggestions, and would be modified within wide limits by the site covered, as well as methods used in care of the forest, planting, thinning, etc.

e. Furniture lumber and Tight Cooperage call for hardwoods in larger sizes with fully matured heart wood where such decides desirable color and other qualities. Here $18^{\prime \prime}$ d. b. h. may be set as minimum. In central Europe, White Oak is grown to an age of I $60-200$ years and even older. It is doubtful if Rotations of over I50 years will be provided for in the future, since combination of good soil and climate and relatively small yield tend to make the raising of this class of timber unprofitable. In addition rapid extension of commerce with the tropics may make it unnecessary to provide for much of this kind of timber in the future. 


\section{b. Rotation for Largest Volume or Yield of wood per acre and year.}

This usually refers to "cordwood and better" (about 3 " thick and over), but in many localities abroad, includes even faggot material. As stated before, this Rotation was entirely proper when certain forests had to supply a large population with fuel, so that fuel had to be shipped into the districts. Today such a Rotation is the exception, but may again come into use with development of the Pulp industry and better facilities for marketing and shipping materials demanded in the s!ack barrel, box board and other industries.

Rotation for largest volume in Germany and for fair to good site ( site II) is about as follows:

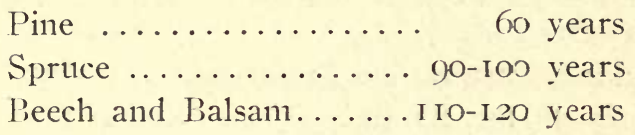

This fits in very nicely with the technical Rotation for these species.

\section{c. Rotation of Largest Yearly Income.}

The following figures will illustrate what is meant here: One acre of Spruce on Site II in Germany may present the following conditions :

\begin{tabular}{|c|c|c|c|c|c|}
\hline \multirow{2}{*}{$\begin{array}{l}\text { Age } \\
\text { of } \\
\text { Stand. } \\
\text { Years. }\end{array}$} & \multirow{2}{*}{$\begin{array}{l}\text { Yield } \\
\text { final and } \\
\text { thinnings. } \\
\text { \$ per acre. }\end{array}$} & \multirow{2}{*}{$\begin{array}{l}\text { Expenses } \\
\text { during the } \\
\text { r years. } \\
\$ \text { per acre. }\end{array}$} & \multicolumn{2}{|c|}{ Net Income. } & \multirow{2}{*}{$\begin{array}{c}\text { Se. or } \\
\text { Rental Val. } \\
\text { of land. } \\
\$ \text { per acre. }\end{array}$} \\
\hline & & & $\begin{array}{c}\text { Total. } \\
\text { \$ per acre. }\end{array}$ & $\begin{array}{l}\text { Average } \\
\text { per year. } \\
\$ \text { per acre }\end{array}$ & \\
\hline 40 & $2 \mathrm{II}$ & 48 & $16_{3}$ & 4.00 & 47 \\
\hline 60 & 654 & 66 & 588 & 9.80 & 98 \\
\hline 80 & $\mathrm{I} 2 \mathrm{I} 2$ & 84 & II 29 & I 4.00 & IO5 \\
\hline 100 & I7II & 102 & 1609 & I6.00 & 9I \\
\hline I Io & 1919 & I I I & I 808 & I6.40 & 83 \\
\hline I 20 & 2087 & 120 & I967 & I6.30 & 75 \\
\hline
\end{tabular}

This table indicates that if the stand is cut at forty years the net income is $\$ \mathrm{I}_{3}$, an average of $\$ 4.00$ per acre and year; if cut at I Io total net income is $\$ 1808$ or $\$ \mathrm{I} 6.40$ per year and acre. After 
this the total net income goes to $\$ 1967$ at 120 years but the average per year begins to decrease.

The table also indicates that the owner receives highest average rental per acre from his land if he cuts it at eighty years or thirty years before highest average yearly income occurs.

In this calculation for Createst Net Income per acre and year, the assumption is that we normally have a forest and not merely bare land; that this forest is reasonably regular so that a yearly income is produced. If then Rotation is eighty years, for instance, we could take an eighty-acre sample of this forest and get from this eighty acres each year:

One acre of ripe timber.

Several acres of thinnings (these are made about every ten years in good forests abroad) and we would have as expenses:

One acre to plant and

Fighty acres to protect, pay taxes on, etc.

Putting this in a formula we have:

Average Net Income per acre $=\frac{\mathrm{Yr}+\mathrm{Ta}+\mathrm{C}^{\prime} \mathrm{l} b \text {, etc. }-\mathrm{C}-\mathrm{re}}{\mathrm{r}}$ where $\mathrm{Yr}=$ Stumpage Value or net Yield of one acre of ripe timber, here eighty years old.

$\mathrm{Ta}=$ Value of Thinnings made when the stand is a years old, etc.

$\mathrm{C}=$ Cost of planting one acre.

re $=$ Value of taxes, protection, administration, etc., i. e., of yearly expenses for $r$ acres.

Using the above table we have:

Average Net Income per acre on eighty year rotation $\frac{\text { I2 I } 2-84}{80}$

\section{d. Rotation for Highest Rent per Acre of Land.}

This is also called "Financial Rotation" and may also be called "Rotation for highest Rate of Interest on Capital." The assumption here is that bare land is the real capital and that by using it to raise timber this land is made to pay a rental, and the object is, in using this Rotation, to secure best net rental per acre. The calculation, then, starts out with an acre of bare land and inquires into the 
amount of material and values we can produce from this acre and the cost of doing it.

The calculation usually employed is based on the following general formula of the present value of a series of rentals coming at regular intervals, and continuing indefinitely as does rent from land.

\section{$\frac{\mathrm{R}}{\mathrm{I} . \mathrm{OP} \mathrm{P}^{\mathrm{n}}-\mathrm{I}}=$ Rental Value or Income Value of the Land where}

$\mathbf{R}$ is the rental, i. e., the net income which can be produced every forty, sixty, etc., years, i. e., every Rotation.

$p$ is the rate of interest.

$\mathrm{n}$ is the number of years to grow the crop, here then the age at which the stand is cut, i. e., the Rotation.

To illustrate:

If cut at sixty years, and the total net income at sixty years will be $\$ 500$; and if $1.03^{67}=5.89$, the interest rate being $3 \%$, the calculation then is $500 / 5.89-\mathrm{I}=500 / 4.89=\$ \mathrm{IO} 2$ approximately. According to calculation, this acre of land brings enough rental to make it worth about \$102 if used for the purpose of growing the special kind of timber and cutting it at the age of sixty years, providing we are satisfied with $3 \%$ on the money spent in planting and all other expenses. ${ }^{1}$

A great deal of controversy has taken place over the last two forms of Rotation, and German foresters are still largely divided into two camps on this question. The tendency is toward a full recognition of the value of financial Rotation with a compromise justifying a larger income with a smaller interest rate or net rental on the

${ }^{1}$ The proper formula to employ in this calculation is the formula for Se, or the Income Value, or Expectation Value of the Soil. This formula in its usual form reads:

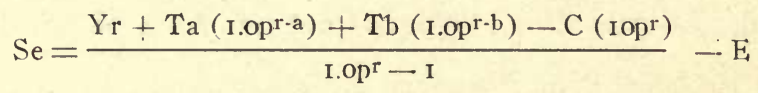

where Se is Expectation Value or Income Value of the Soil, or land per acre.

Yr is Stumpage Value of one acre of timber $r$ years old. (Ripe timber.)

Ta is thinning made when the stand is a years old.

$\mathrm{Tb}$, thinning when stand is $\mathrm{b}$ years old.

$\mathbf{C}$ is cost of planting or establishing the young stand of timber on one acre $\mathbf{E}$, yearly expenses, protection, taxes, administration capitalized at $\mathbf{p} \%$.

$\mathrm{p}$ is interest rate used, usually $3 \%$. 
land. An illustration from the management of a farm will explain the attitude of those opposed to a rigid adherence to this financial Rotation: A does little work, has poor buildings, little stock, small investment. He also has a poor crop, but this small crop forms a large per cent of interest on his investment.

B employs plenty of help, has good buildings, lots of live stock, large investment. He has a large crop tut this large crop is but a small per cent on his investment. According to census figures a farm in Alabama pays a higher rate of interest on investment than that of Illinois, but the latter has easily twice as much income per acre per year. Generally B with his well tended farm is considered the right farmer and not $\mathbf{A}$.

The new Bavarian Instructions expressly state that rotation should be so chosen that demands of the home markets are best supplied, and a fair income is secured.

The latest Prussian Instructions do not discuss this point, evidently a refusal to commit the State to the principle of a financial Rotation, for which there has been a great deal of clamor.

\section{e. Physical Rotation.}

Besides the foregoing four kinds of Rotations authors generally mention a fifth one, Physical Rotation. This is little explained as a rule. Judeich says it is a Rotation where timber is cut at a time when easiest reproduced, bears plenty of seed, or sprouts well (in coppice), or else it is natural Rotation where timber is allowed to go as long as it will live naturally.

Neither of these conceptions are very helpful. More useful is a consideration of the relation of Rotation and up-keep of fertility of the land. This is important especially in forests of Pine and other intolerant species stocked on poor sandy lands. Here the stand opens up after it gets to be $50-80$ years old, and allows wind and sun to injure the soil by destruction of humus and by drying.

Even on fair soils as in Oak woods such soil-deterioration takes place and must be met either by shortening Rotation or by underplanting, or other silvicultural means.

Generally, then, Rotation is suited to market, to rate of growth, and therefore to Site, Species, and treatment. But in all forests 
many stands never grow as is expeced and hoped, and must be cut younger or left to grow older than is prescribed by the Rotation. For these and other reasons some authors have suggested that Rotation is an unimportant conception, and that it is useless to try to decide on a definite Rotation. Even among foresters of experience the opinion is not rare that Rotation is set by guess or feeling. The fallacy of all this is evident from the foregoing. The table of net incomes pictures faithfully what actually occurs in the forest regardless of the figures used, and if it makes land worth $25 \%$ more by cutting at eighty years it is certainly poor policy to let the stuff go to an age of I Io years and take a smaller per cent interest besides much longer risk. That European Governments consider Rotation of great importance has been stated. In addition it may be said that Regulation of any forest demands establishment of a definite Rotation, just as much as any big enterprise requires definite estimates. Organization of large railway and other transportation systems is usually based, of necessity, on assumptions which are probable but never exact or certain.

Experience of the last 100 years in Europe proves conclusively that growth in the forest is sufficiently regular to be estimated to any degree of accuracy here demanded. But it also indicates that there is a limit to this degree of accuracy and that there is no need of hair-splitting, but that a range of 5 -10 years must be conceded even in Rotations of 60-100 years.

Generally, longer Rotations denland larger capital in form of timber, involve more risk for any one stand, tend to reduce rate of interest on the capital, but make for larger income per year and produce a material of better price and a much larger market, and usually are better for maintaining the site.

\section{f. Natural Rotation.}

In wild woods is the average life of the Species. In a pure stand of intolerant species such as Lodge Pole, Longleaf, Loblolly or Norway Pine, Tamarack, etc., the old timber, even though stands open up considerably, prevents reproduction effectively. When once the stand breaks it is readily hurt hy storm and the great number of defective, dying and dead trees also invite insect trouble and fire. Accordingly these pure stands of hard pine and other intolerants are 
apt to break down fast, and leave the ficld practically free for young growth which now gets plenty of light to start. This new stand is practically even aged, trees develop and grow old together and the story of decline and replacement by a new stand repeats itself. With these species the pure even age stand is rather rule than exception in our wild woods.

In mixed stands of hardwoods the case is entirely different: Normally the site (soil, etc.) is much better; the several species differ in tolerance, growth, reproduction and they vary in longevity and resistance to injury. Here the stand does not go down together (unless it is a case of windfall), is constantly reproducing, every opening is filled, it rarely forms even aged stands over large areas and even when it does (after accidental destruction) reproduction sets in long before the old stand really breaks. We have the Selection Method practiced by nature. It is reasonable to assume that on any one township of hardwoods in the Ohio Valley in virgin state the total amount of timber remained fairly constant; growth and decay balanced, old, middle aged and young stuff, i. e., the Age Classes were properly represented; rotation varied for different species, but it was always the average life of the species. In this way these virgin, mixed woods presented a certain regularity comparable to that attempted by the forester. On the other hand, a property stocked with pure stands of even aged pine, etc., may or may not be regular. In fact there are areas of Lodge Pole Pine of over 100,000 acres in which certain age classes are almost wanting, a fact which needs consideration in planning for a steady supply of timber and income.

\section{g. Choice of Rotation in United States.}

Generally, Rotation should be chosen no longer than is necessary to produce desired material, a good income from the land, with full assurance that the fertility of the land is not impaired.

On good sites, with good growth and high stumpage calculation of net rental on a reasonable interest rate should never be omitted. In such calculation the following facts should have due consideration :

I. Sizes demanded by the Market are growing smaller, but will probably not go beyond present European limits. 
2. A good practice of thinning can reduce Rotation by many years.

3. Planting of strong plants, 4-5 years old and proper spacing can in many places save ten years on Rotation.

In our wild woods and where a beginning is made by the selection method, the natural Rotation is apt to be misleading. In certain Lodge Pole forests a technical Rotation is indicated by the time it takes to grow a railway tie; say I50 years. If this forest is to be regulated, as to yearly cut, by Hundeshagen (or Von Mantel's modification of this) it becomes necessary to set a definite Rotation. In deciding this Rotation, the temptation is to use the age of "mature stuff" and employ natural Rotation as criterion, largely on assumption that a shorter Rotation would furnish a much smaller volume. If the cut is $12 \mathrm{M}$. ft. per acre and mature stuff largely $200-250$ years old, the assumption usually is that it takes about 200 years to produce this volume of $12 \mathrm{M}$. $\mathrm{ft}$. This is an error, and it will be found, in most cases, that volume (not only in tie.timber) is fully as great, say, at 150 years, as at any time later, and that, therefore, this Rotation of 150 years not only furnishes the proper size, but fully as large a volume.*

* That a stand of timber does not add volume indefinitely, or even to great age is self evident and is well shown by European Tables. And no amount of care in thinning, etc., is able to change materially this fundamental fact. In wild woods pure even age stands reach the point of maximum volume apparently much earlier than in forests receiving proper care.

In Oak, site I (as per Schwappach) yield of stuff $3^{\prime \prime}$ and better of the "main stand" is, at I40 years about 7000 cubic feet, and at the age of 2co years only 8500 , making only 1500 in 60 years in spite of all care. In Scotch Pine yield per acre does not materially increase after i2o years, even on good sites and with best of care. Schwappach's tables give for the "main stand" at I00 years about 6000 cubic feet and for 120,6300 , and only $6+00$ at 1 \%o. These figures are for fully stocked stands and must, in this respect, be regarded the exception, for it is here where Silviculture finds its hardest problem, to keep the stand intact. A century of storm, hail, ice, insect and disease affects the forester's efforts, and German forestry today has not yet succeeded to hold its stands better than about $85-90 \%$ stocked, even up to Ioo years, and longer Rotations would certainly reduce these percents rapidly. In wild woods dense stands of the sapling and pole age introduce great and lasting struggles, ordinary and normal competition helps to injure the forest, and there is no agency to correct this mischief. Results are evident, the fully stocked "forty" in wild woods is rare, particularly in pure stands of intolerants. 


\section{F. REGULATION OF THE CUT IN AMOUNT AND IN LOCATION.}

German: "Ertragsregelung" including the "Hiebsordnung."

\section{General Considerations.}

Since Forest Regulation aims to make a forest property into a regular business with yearly income proportional to investment, and since timber ordinarily requires fifty and more years to grow, cutting of the timber must be adapted or regulated to fit into the general plan.

I. The farmer harvests all that grows on an acre of land each year, the forester must let growth on any one acre accumulate for fifty and more years. The farmer harvests growth from all his lands each year, and his yearly harvest is exactly what grows in that particular year. The forester, to have a yearly cut and income, must regulate his business, and in any case he does not cut what grew in that particular year, but an amount equivalent to the year's growth. in fact he cuts what grew during the last fifty or one hundred years on a part of his land. In this way the forester's crops average up and yearly income is not fluctuating to such a degree as it is on the farm.

2. To be able to cut a crop of ripe or eighty-year old timber each year, the forester of a 20,000 acre property must have areas of old, middle age and young timber at all times. In this particular case he would really need 250 acres of 80 year old, 250 acres of 79 year old, etc., all the way to 250 acres of one year old stuff. This perfect regularity is not possible; fire, storm, snow, frost, insects and disease, all help to disturb regularity even if it were possible to establish.

3. In practice the forester is satisfied if he can get an approximation to this, such that he has, in the above case, 5000 acres of stuff between 60 and 80 years, 5000 acres $40-60$ years, etc.; i. e., that each twenty year Age Class, have about an equal area of land. To bring about this regularity of Age Classes in the forest is one of the chief objects of regulating the cut.

4. This regularity, when once accomplished, not only assures a yearly cut and income, but it does more. Assuming proper care 
in Silviculture, this regularity provides the following fundamentals of good forest business.

a. Yearly cut of about equal volume.

b. Yearly cut of about the same age, size and quality of timber, and hence a yearly income of about the same amount.

c. Growth and income is secured on a capital no larger than is necessary, and therefore this regularity assures the largest per cent of interest on the capital.

d. Best growth under given conditions of site, species and rotation.

e. Greatest degree of safety from fire and other dangers, since the forest is never made up entirely of young, or of old stuff.

In short the forest is in a properly regulated or "normal" condition.

5. From the above it follows that if the forester "over cuts", i. e., cuts much more than the proper area or amount of timber, he cuts into the "capital" and must make up by saving, later on. If he "undercuts", i. e., leaves a lot of ripe stuff on the ground, he reduces growth and income, for old stuff does not grow as fast as young timber. For any given place or forest there is a certain Rotation which is better than a longer or shorter one, and once this is decided upon, Regrilation of the cut is bound by it.

The lumberman normally overcuts, and thereby cuts capital and growth; the farmer in his woodlot often overcuts in one place and undercuts in another; Bavarian State forests for years have been undercut, and income kept unnecessarily low. Overcutting a forest tends to devastation and neglect. As soon as yearly income fails or becomes too small, the owner loses interest, he "retrenches", i. e., he neglects, and the mischief grows at geometric ratio. Overcut also hurts market either by over-production or by failure of regular supply. Experience in the United States as well as abroad is the same on this point.

Regulation of the cut, then, should prevent overcut as well as undercut in the forest.

6. Keeping in mind the changes in market, bad seasons, fire, insects and other enemies, and then also mistakes of the forester which disturb regularity of reproduction, growth and devclopment of the many stands of timber in a forest, it is evident that this regu- 
lation of the cut is never more than a good approximation, and also that it is never finished but needs revision from time to time in order that regulation fit the changed conditions of the forest due to growth, cut and injury.

7. Where Clear Cutting, or Shelterwood systems are used, and also where, as in Western Yellow Pine and Lodge Pole, the Selection method and clear cutting are combined in various ways, in fact wherever an area of land is cleared and the old stand replaced by a young, even aged (or approximately even aged) stand, there enters a new factor in this matter of regulation:

Order, Direction and Distribution of the Cut, "Hiebsordnung, Hiebsfolge") determining Distribution of Age Classes, i. e., Distribution of old and young stands in the forest.

8. 'This proper distribution of stands of young stuff, middle age and old timber is demanded by Silviculture and by Protection and on large properties also by local market. To illustrate: Assume a forest of 20,000 acres, one solid block of level lands, all Spruce, Rotation eighty years. Also that it is possible to cut 250 acres each year and replant. If this cutting were done in strips running north and south, there would be a strip of 250 acres each year, and in twenty years there would be a solid body of 5000 acres all covered with young stands from I-20 years old, most of them dense brush, highly inflamable, and completely ruined if fire ever got in. Danger from insects and fungi need not be mentioned.

Again suppose an attempt were made to cut the stands from West to East. A solid line, six miles long, of large timber would be left without protection and, in case of Spruce, surely be thrown by the wind, the mischief going right ahead of cutting, making miles perhaps, during a specially bad season. Suppose this same area were entirely cut over and cutting ready to begin along the East line. If now it should happen that certain tracts in the middle of this area were injured by fire, or insects and had to be cut at once, such cutting would make a break in the cover and set the mischief of wind fall going. But these accidents and many others must be met in every property and during every rotation.

Again in mountain country every valley has its own peculiarities as to wind and storm, and these need to be considered, the aim being always to "cut against the wind", and also to avoid having to 
move cut timber through areas recently restocked with young growth.

Then also it has long been found that it is much easier to reproduce a stand of timber, whether by natural or artificial reproduction, if the area to be covered is small and surrounded by forest. Since this is largely a matter of drying winds, it is most important in dry and windy situations and districts (I,ake Region, Rocky Mountains, etc.). This matter has become a principle in Silviculture. Good Silviculture calls for small cutting areas, and these properly restocked before cut of timber proceeds.

9. To bring this about, one of the principal efforts in Regulation is to direct the cut of the forest in such sequence or order as to enable the forester to have:

a. Small Cutting Areas.

b. Many separate tracts at any one time where ripe timber can be removed; i. e., many points of attack.

c. No large area covered with timber of one age and in such condition that he can not cut any portion without serious danger to the rest, or surrounding timber.

d. To have the cut proceed against the wind and so avoid danger from windfall.

e. Avoid large areas of young stands (especially important in conifers on account of fire).

Io. To enable the forester to plan and cut timber in proper order and direction, to enable him to get at every stand whenever it is in need of cutting and reproduction, is fundamental in all methods where the forest cover is entirely removed at times.

I I. Cutting Series (Germ. Hiebszug). To do this, however, the forest needs a proper division beyond mere land-division into lots described before. It is necessary to divide the forest into a number of small independent parts, each separated from its neighbors by a broad line and each surrounded by a satisfactory forest border. These independent parts are the Cutting Series.

I2. Centuries ago when there was either Coppice, Standard Coppice or Selection forest there was no demand for this division into Cutting Series, but with development, espccially of the Clear Cut and plant method, it became a silvicultural necessity. 
At first, especially on level ground and easy slopes, these Cutting Series were made large, often of five and more lots, and there was devised by Reuss a regular form of arrangement for them. The older Cutting Series were so large that they required the greater part of, or the entire Rotation to cut over.

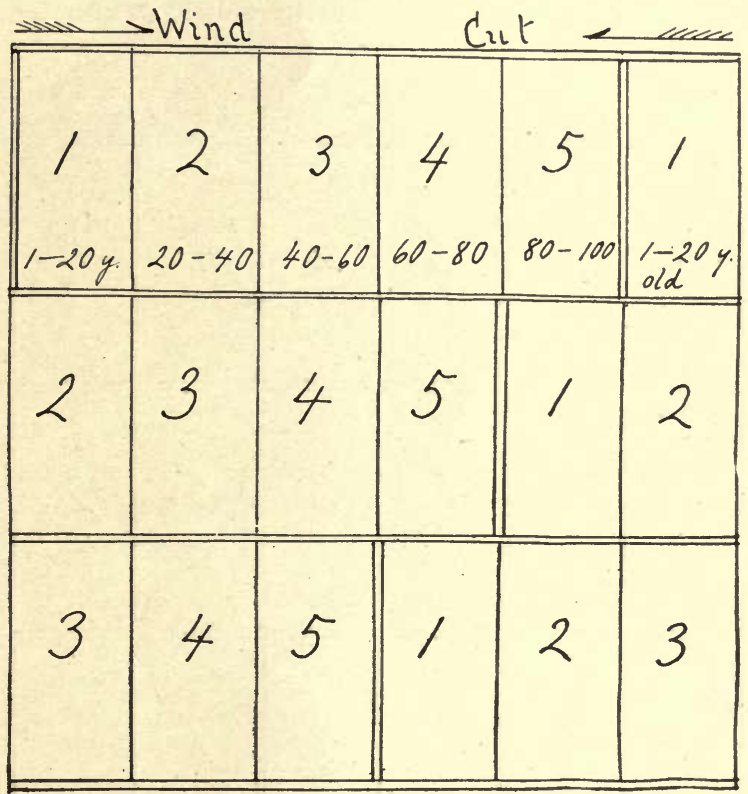

Figure; 3. Division into Lots and Cutting Series, showing the old or "Normal" form of Distribution of old and young stands in the Forest. Lots I-5 in the upper tier, form one cutting series for a roo year rotation, the plan being to cut one lot every 20 years. The cutting series is surrounded by a broader line (30 feet) so that a forest border can form, and thus it becomes quite independent of the surrounding woods. Schematic, and conditions as they should be at begin of rotation, in this case, once every 100 years.

In the diagram, Figs. 3 and 4, illustrating the old and also the Reuss pattern the Cutting Series in Fig. 3 has five compartments. If the timber is worked on a roo-year Rotation, and has five Age Classes, a cut is made every ten years to give reproduction a chance. Then the forester cuts $1 / 2$ of No. 5 , and plants; in ten years he cuts second half of No. 5, etc. In this way the Cutting Series is just 
covered during one Rotation, and every Cutting Series on the property is planned to be cut over in this same sequence and at the same rate.

These old time Cutting Series proved too large and have been generally abandoned. Today a Cutting Series is commonly made up of two lots, often of a single lot, and is cut over in ten or twenty years, and normally in much less than the full Rotation.

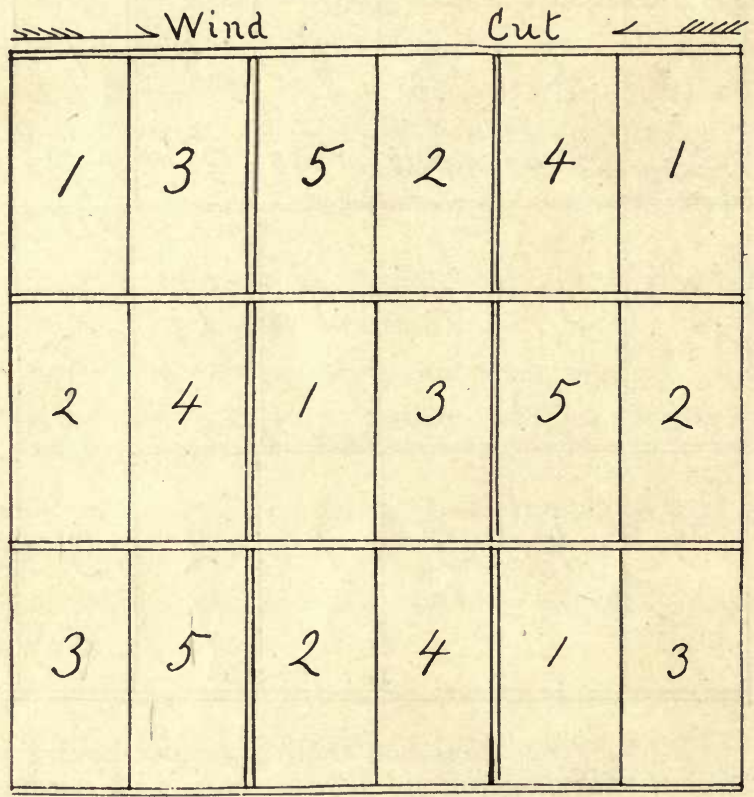

FIGURE, 4. Reuss' Pattern of Division and Distribution of old and young Stands. This separates the oldest, and the youngest better than is done in Figure 3. In any case the danger line is the line between the oldest and youngest stands. Schematic and conditions as they may be found at any time. Only two lots in each Cutting Series; this is optional.

Mayr in his Waldbau recommends going a step further and making the Sub-Lot or even a smaller area the Cutting Series to enable a better use of the land; his idea being that each stand should be pure, i. e., of one species, but that the stands should be small, and different kinds of these small stands mixed to produce a mixed forest of pure stands. 
I3. The advantage of breaking up the forest into a large number of independent parts is evident from the following case:

Area of forest : 20,000 acres.

Rotation: 8o years, hence 4 Age Classes.

Method: Clear Cut and planting.

Lots average 80 acres $\therefore 25^{\circ}$ lots.

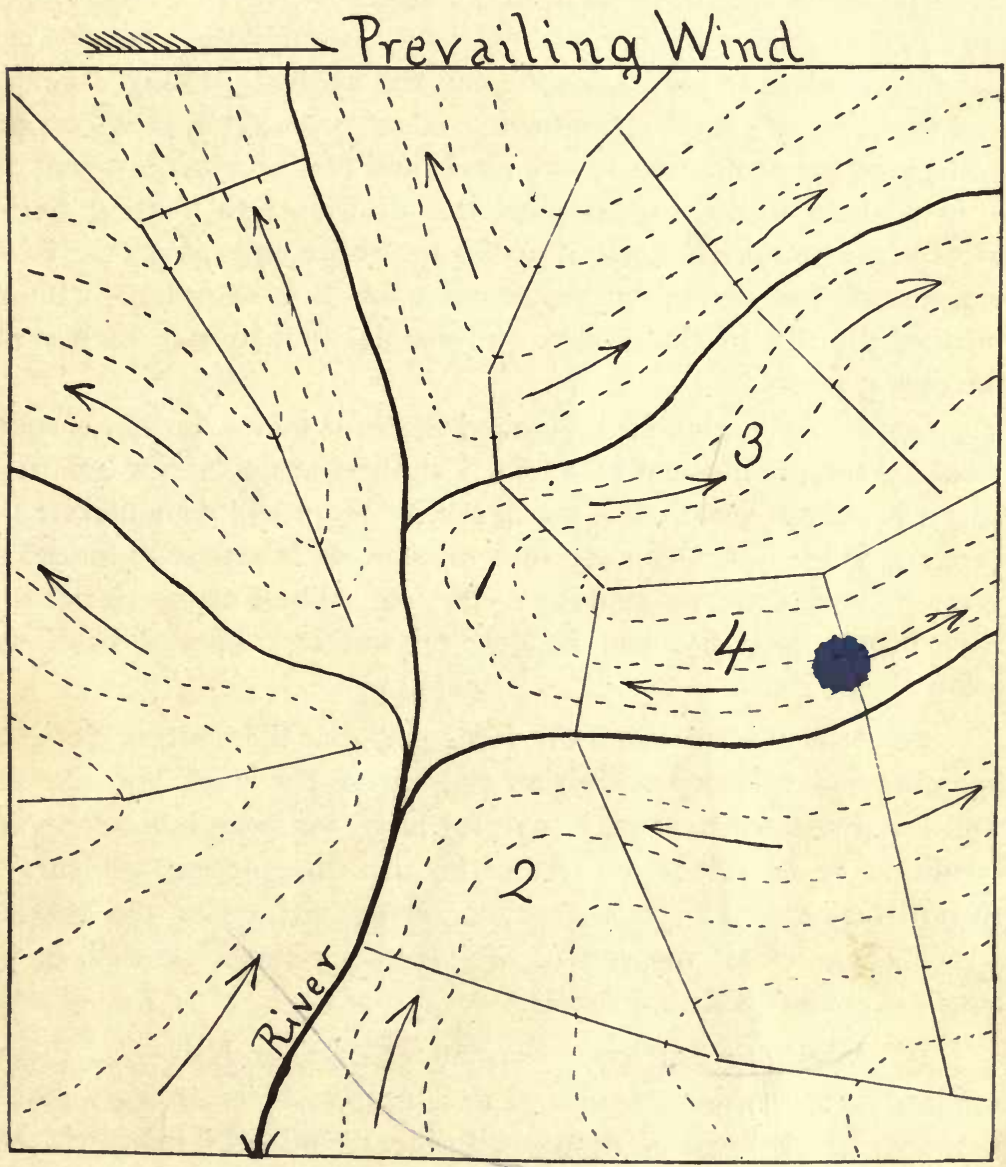

FIGURE 5. Direction of Cutting in High Mountain Country. The dangerous winds come down the Valleys. In lot $\mathrm{I}$ and also in No. 2 a stormpoint is produced by the position of the Valley on W. side. This also makes it desirable to cut down-valley in lower part of No. 4 , but not in No. 3. Arrows point in the direction in which to cut. 
Cutting Series of two lots each $\therefore$ 125, of 160 acres each.

Yearly cut (by area): 250 acres.

Cut during one "period" or 20 years : 5000 acres or about $3 \mathrm{I}$ Cutting Series.

Cutting area 40 acres, with 5 -year rest between cuts at any one place.

Having over thirty different Cutting Series or independent parts, all of them with ripe or sufficiently ripe timber, ready to cut, the forester has ample choice. he can cut at thirty different points, and if at any one point reproduction is not succeeding, if insects are destroying his plantations in any place, and it is necessary to wait, he is in position to do so. In short this division into Cutting Series gives many points of attack, it makes the entire enterprise "flexible", enables the forester to cut any stand when it is necessary, without hurting the rest of the timber, and enables him to give each stand the care it needs.

In our beginnings in the United States it may seem too early to speak of such refinement of methods as the Cutting Series indicates. But it is almost certain that the next fifty years will demonstrate the dangers and losses which are sure to come with extensive unbroken areas of pure growing stands of pine, etc. The Cutting Series is a silvicultural necessity, and its development is neither difficult nor costly.

I4. It is evident, from the foregoing that the Cutting Series is not always a permanent division right from the start, but, like the Sub-I,ot, or stand division, it may for many years be in a temporary condition of development. As to its size, the present tendency is toward making each Lot a Cutting Series and getting the greatest possible use out of the system of lines maintained, as well as the smallest possible Cutting Series.*

I5. Working Section. German: "Betriebs Klasse". Where a forest property is of ordinary size, ( 25000 acres or less) and is made up of one type of timber, all pine, all mixed hardwoods, etc. Regulation of the cut usually applies to the entire property.

* See Martin, "Zeitschrift für Forst und Jagdwesen," 1905, p. 86, on Forest Division in Austria.

Also, Wagner. "Räumliche Ordnung im Walde," which treats entirely of this silvicultural division of the forest. 
Where the property is made up of two or more, radically different types of woods so that each of these types requires special treatment, then the forest is divided into two or more Working Sections. The following illustrates this:

\section{Area : 20,000 acres.}

Location: Michigan Pinery district.

Types: Hardwood and Hemlock......35\% or 7,000 acres Pinery proper ............ $50 \%$ or 10,000 acres Tamarack and Cedar Swamp.... I $5 \%$ or 3,000 acres

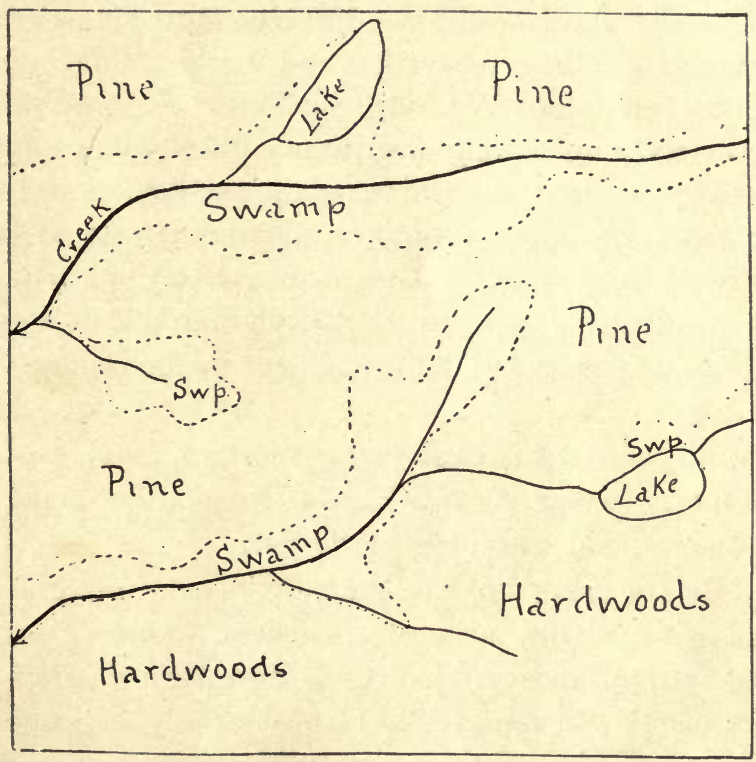

Figure 6. Township of Typical Lake Region Pinery Lands with three types of lands and three permanent types of forest; Pinery lands with pure and mixed stands of Pine; Hardwood and Hemlock forests on slightly heavier soils; and swamp lands stocked with Tamarack, Cedar, mixed with Spruce, Pine, and Hardwoods in better drained spots. These three types call for different species, silvicultural methods, and rotation and therefore demand three separate Plans, each type forming one Working Section.

From the diagram, Fig. 6, it is apparent that the swamp forests are in several pieces of irregular shape, following drainage lines. The plan of Silviculture here proposes to treat Pine by the Clear Cut and plant method, Hardwoods as Selection forest, and swamp 
timber by cutting clcar in strips and depending on natural reproduction.

In this way the three types of woods, on three very different kinds of land or sites, may be expected to differ always. Regulation of the cut is made much simpler, the plan much clearer, by making a separate plan of Regulation for each of these three types, and treating each type as a separate Working Section, just as if it were a separate property.

In larger properties, and in properties made up of several separate tracts, miles apart and especially in mountain districts where different watersheds have different local or general markets, this matter of distance, separation and market, alone justifies division of the forest into Working. Sections. A forest like the Big Horn, over sixty miles long and twenty miles wide, supplies settlements many miles apart. In this case each settlement or local market requires a steady supply of timber and the forests of each of the larger stream basins may well be made into an independent Working Section, with its own plan of Regulation and its own series of Age Classes, or young and old stands and its own continuous supply of timber.

From the above it is clear that a Working Section is a part of a forest property having its own Plan of Regulation of the cut, series of Age Classes, and sustained yearly cut.

Up to sixty years ago the great importance of local market as compared with distant, large city markets, was so great that each Working Section, and certainly each Forester's District ("Revier" of the Germans) was expected to furnish strictly the same amount of timber, year by year. With extension of railways, local market lost in importance and large forests depend almost entirely on distant markets. In such cases an equal cut each year from each forest or Working Section is no longer so necessary, and there is considerable agitation abroad to do away entirely with this requirement of a sustained yearly cut even for each district or "Revier". While, perhaps, permissible in the case of State or National forests and for large forest properties, yet its advisability is doubtful. 'The State forest which will be cut over regardless of future regularity of supply and left for twenty-five years without any timber cut and income, will not fare well in allotment of appropriations. 
16. Where Regulation of the cut and orderly work begins in Lwild woods the following is acconplished:

a. Decay is replaced by harvest or cut of ripe timber, and decay is therefore reduced to an insignificant amount, the unavoidable - defect.

b. Natural Rotation is reduced by many years, and changed to a business rotation.

c. The amount of timber, the "Growing Stock" is usually reduced. In many cases this is not true, for the growing stock in wild woods is not always large, due to defective and useless stuff and unstocked ground.

d. The condition of equilibrium where growth and decay balance changes to a condition of net growth.

e. This net growth is improved by good silviculture which eliminates weeds, and keeps all lands stocked with most productive species.

f. Fertility of the land is usually reduced, at least in time. In the United States fires in the pineries and mountains have done this to a serious degree.

I7. Natural Regularity in Wild Woods. In wild woods, too, there is a certain degree of regularity, comparable to that sought by the forester. This is greater in mixed hardwoods than in pure conifers, as pointed out under "rotation", especially those of intolerants like hard pine, Tamarack, etc.

In mixed hardwoods in Southern Michigan it is probable that even on a single township of virgin forest the following conditions were maintained:

a. Rotation equal to average life of the trees of each species, hence varies with composition and is never uniform for entire stand.

b. Age classes generally well mixed on every forty; all age classes represented; all-old and even-aged stands of any size the exception.

c. Growth only fairly good, and not good in keeping with the excellent sites; too much over-mature, crippled, defective, spreadcrown stuff; then also a great deal of poor stuff and brush, (Blue Peech, Hornbeam, etc.) 
d. Growth offset by decay, the forest in a condition of equilibrium (just as in a well regulated condition). For this reason no net growth on the entire area.

e. Growing stock quite large but not in keeping with the long (natural) rotation and excellent site. From measurements made it is clear that on areas of 300 acres and more the growing stock up to 200 years old was frequently much less than could be produced by healthy stands half that age.

In forests of Lodge Pole, Western Yellow Pine, Norway Pine, Tamarack, Longleaf Pine, where even aged stands prevail the conditions on a property, even of 50,000 acres do not "even up", and we may and commonly do have:

a. Rotation, quite uniform, and equal to average life of the tree, over 200 years.

b. Age classes on separate areas, not generally mixed, with some classes wanting. These, according to studies thus far made most commonly the middle sizes or large poles, (mere accident). Classes prevailing are mature or old stands, so much so that the statement has been made that the forest is made up of all old, i. e., even age mature stands, which, of course is not true for large properties.

c. Growth over large areas often very small, due to dry, poor or cold sites, to prevalence of old broken stands and large per cent of bare ground.

d. Growth and decay do not balance even on large tracts; in some cases decay over balances growth, while in others considerable net growth exists, and only a complete study determines the true status.

e. Growing stock rarely large, commonly smaller than a properly stocked and regulated forest would have at half the natural rotation.

In forests of tolerants, such as Spruce, Hemlock and Balsam the conditions resemble more those stated for mixed hardwoods. But in keeping with the simple composition (one species often) the condition is intermediate. In all cases some reproduction sets in as soon as the stand begins to open or break, but quite commonly it leads to rather even aged, more than many-aged stands and in this respect approaches the condition of pure stands of pine. 
On most of the large properties several types of forest are represented. In the Great Lakes Region pinery there is rarely an entire township without some swamp forests and hardwoods or hardwood and pine mixed stands. Naturally each of these presents its own regularities of rotation, age classes, etc., and needs to be considered separately.

\section{Methods of Regulation of the Cut.}

\section{A. General Consideration and Classification.}

I. Plan of Regulation of the Cut involves two distinct tasks:

a. Regulation for Regularity of Age Classes, and with this of Regularity in Amount of timber cut, i. e., for a forest in which there is always a proper amount of young, middle age and old timber, in which, therefore, the different age classes, 0-20, 20-40, 40-60, etc., year old stuff occupy about equal (or equivalent) areas of land, and supply a yearly cut of about the same Volume and Value.

b. Regulation for Proper Distribution of Age Classes in the Forest (Hiebsordnung, of the German) i. e., for a forest in which stands of young stuff, poles, and older timber are not in large, unwieldly bodies, made up of stuff of about the same age, but are in small stands regularly mixed, judiciously arranged to enable good Silviculture, effective Protection, and convenient Utilization. In the Selection forest mixture of Age classes is by smallest possible areas and represents really the greatest refinement in this direction.

2. Where forestry is once well under way and where even age stands are to be grown on large properties, the second of these tasks, proper Distribution of stands is more important, and practically reduces the first, Regulation for Age Classes to a very simple operation.

Regulation for a Proper Distribution of Age Classes depends on a suitable division of the forest into permanent Lots and into Cutting Series, and once the forest is properly divided and the Cutting Series developed, further Regulation of the Cut is largely assured. But this Regulation for Proper Distribution of Age.Classes must be worked out for each forest right on the ground. The book and 
school can do little more than give a few principles, to guide in the work. It needs study of the forest, and years of observation and experience with species and site. For this reason the subject is dealt with briefly in the textbooks on Regulation, is almost lost sight of in some of them, in spite of the fact that it is just in this phase of the work where knowledge, experience and capacity are most needed.

3. Regulation for Regularity in Age Classes as stated above, works for sustained yearly cut of about equal amount and value, for best growth possible under given conditions of Site, Species, Silviculture and Rotation, and for a Growing Stock or amount of growing timber on the land, no greater than is necessary to secure growth and income. It prevents Overcut and Undercut.

It is particalarly at this last point, the prevention of Overcut and Undercut that this Regulation begins on new or wild woods property because the first question asked, when there is once market for the timber, is: how much can we cut on this property without overcutting?

4. From the nature of a forest property it is clear that there are really only two ways of regulating the cut of timber: by Area or by Volume. If a forester has a property of 20,000 acres and works on a 100 ycar rotation, he can:

a. Cut an Area of 200 acres per year and cover the property every roo years; or he can

b. Cut an Amount or Volume of timber wlich he believes or estimates to be equal to the amount which grows on his property, say i 5, ,oo cords.

5. If faithfully persisted in and carefully revised every ten or twenty years, and if Silviculture and Protection are attended to, either of the two plans will regulate this forest. If he regulates by Volume, he must begin somewhere and cut a sufficient area to get the Volume estimated to be right, and he must do this year after year. After going over the property once or twice, he will almost certainly drift into a method, cutting over each year the area he cut during one year on his former round; in other words, a Regulation hy. Volume is practically certain to change into a Regulation by Area, which as Cotta correctly foresaw, over a century ago, is the final in all Forest Regulation. 
6. In practice the two Methods have often been combined, and in Classification of these Methods three forms are usually spoken of :

Regulation by Area, by Volume, and by Combination of Area and Volume. To be exact, however, Regulation in these Combined cases is a Regulation by Area with Volume as a check. In the above case the forester may decide on cutting over about 200 acres and also decide that he does not want to cut over $1_{5}, 000$ cords. If then he cuts his 15,000 cords and only needs 180 acres to do so he violates his area-regulation, and if it keeps up, he will also violate his rotation. Nevertheless this volume check enables him to offer the market equal quantities of material, and this advantage is sufficiently great, so that this volume check is commonly applied abroad though fundamentally an Area Regulation is maintained.

7. Methods of Regulating the Cut in amount, by Area or by Volume, all tend toward Regularity of Age classes, for it is only by establishing this regularity of Age Classes that any method of Regulation can hope to secure the benefits of properly regulated or "normal" forest as set forth above.

But none of these methods in themselves attend to the second great task of Regulation, mentioned before, Proper Distribution of Age Classes, or stands of different age, in the forest. In the above example, the forester may cut one piece of 200 acres after another, so that at the end of twenty years he would have 4000 acres of young stuff in a solid body, from the standpoint of protection a most undesirable condition, in Pine and similar timber.

8. Being simply based on a known Area of land or an estimated Volume and a Rotation agreed upon, or some kind of combination of these, the matter of Regulation of the Cut in Area or Volume lends itself to mathematical treatment quite in the abstract. For this reason a goodly number of such methods have been devised and published, and new ones are still springing up almost every year, in spite of the fact that only a very few ever really entered the practice and that after a century of discussion and trial, greatest authorities and greatest owners of forest, like the States of Germany have practically all returned to one simple method, the Limited Area Allotment, with a Volume check, the "Judeich's Method" of 
Schlich, the "Bestands wirtschaft" or "Alters Klassenmethode" of Judeich himself.*

9. The following Classification of Methods of Regulation of the Cut "Ertragsbestimmung" or "Ertragsregelung", is taken from Judeich.

a. Area Methods ("Flächenmethoden").

J. Fixed Yearly Cut (Schlich); "Schlageintheilung".

2. Area Allotment; ("Flächenfachwerk").

b. Volume Methods ("Massenmethoden").

I. Volume Allotment ("Massenfachwerk").

2. Methods based on Normal Growing Stock ("Normalvorraths methoden").

c. Combined Methods ("Kombinierte Methoden").

r. Area Allotment with Volume Check "Kombiniertes Fachwerk".

2. Combination of Area Allotment with Methods based on Normal Growing Stock.

3. Age Class Methods, i. e., Methods working primarily for Regularity of Age Classes.* "Altersklassenmethoden" or "Bestandswirtschaft".

As a fourth form he mentions Wagener's Regulation by Cuts of Equal Value, which apparently is, mentioned more as a curiosity than a thing of value in practice.

\section{B. The Regulated or Normal Forest.}

Study of a model forest, a perfectly regulated forest, fully stocked and all stands in satisfactory condition, i. e., a "Normal Forest", is of help in understanding not only the methods, but also the real objects of Regulation of the Cut.

* See also the recent Textbooks of Judeich, Martin, Guttenberg, Stoetzer, Weise; also Official Instructions of Bavaria, I912; Borgman's "Die Entwickelung d. Forsteinrichtungswesens-Eberswalde-Biesenthal"; and Schilling's Article in "Zeitschrift für Forst und Jagdwesen," I9r3, October.

* It is singular that Judeich persisted in the above Classification of this most important of all Methods. A glance at his problems and explanations shows that it is an Area Regulation with volume merely as a check. Stoetzer (see p. 213 of his book) recognized this and calls it a "limited Area Allotment", "beschränktes Flächenfachwerk. See also Schilling in "Zeitschrift für Forst und Jagdwesen," I9I3, October. But also Wagner's “Grundlagen, etc." 
I. Let a given forest have an area of 12,000 acres, all of the same quality of land, site II, and be stocked with Pine, managed on a rotation of sixty years. Being perfectly regular in age classes, there are on this forest in the fall of the year and before the yearly cut is made, 200 acres of sixty-year old timber, 200 acres of fiftynine-year old, etc., down to 200 acres of plantations one season old.

2. If we take one acre sample of each of these stands we get a miniature model forest of sixty acres with one acre sixty years old, one acre 59 years old, etc.

This small model or sample forest can be regarded as a separate normal forest and what is true of this sample applies also to the 12,000 acre forest.

This sixty acre model or sample is represented by a diagram in Fig. 7 ; each strip represents the volume of wood on one acre of land. The strip at the right represents one acre of sixty years old timber now ready to cut or the Yield of one acre, i. e., Yr., say 5600 cubic ft.

3. If the silvicultural plan is to cut clear and plant at the age of sixty and thin each stand every six years, then the work on this Normal forest of sixty acres is as follows: Each year there is: .

One acre cut clear.

One acre of six-year old, one acre twelve years old, etc., in all nine acres are thinned.

One acre is planted.

Sixty acres are cared for and have taxes paid on them.

4. I,eaving out of consideration growth and cut of stuff removed in thinnings, the following is true:

a. Cut each year is 5600 cubic ft., i. e., the stuff on one acre of ripe, or sixty-year old timber.

b, Growth on the sixty acres is 5600 cubic ft. per year or the amount cut each year. The growth being sixty acres, and the cut on one acre we do not cut the growth of the year, but an amount equal to the growth.

c. Growing Stock on sixty acres is indicated by the triangle at least closely enough for our purpose here. 'This triangle has an area :

$$
60 \times 5600 / 2=\mathrm{Yr} \times \mathrm{r} / 2 .
$$

Growing Stock 168,000 cubic feet. 
d. Growth on this sixty-acre sample of normal forest during one rotation of sixty years is $60 \times 5600=336000$ cubic feet, or twice the amount of Growing Stock found on the sixty acres at any one time. In other words, the Growing Stock is replaced every thirty years, or in general in $r / 2$ years.

e. Growing Stock is reduced each winter by the yearly cut, of 5600 cubic feet, and is replenished the following summer by the season's growth.

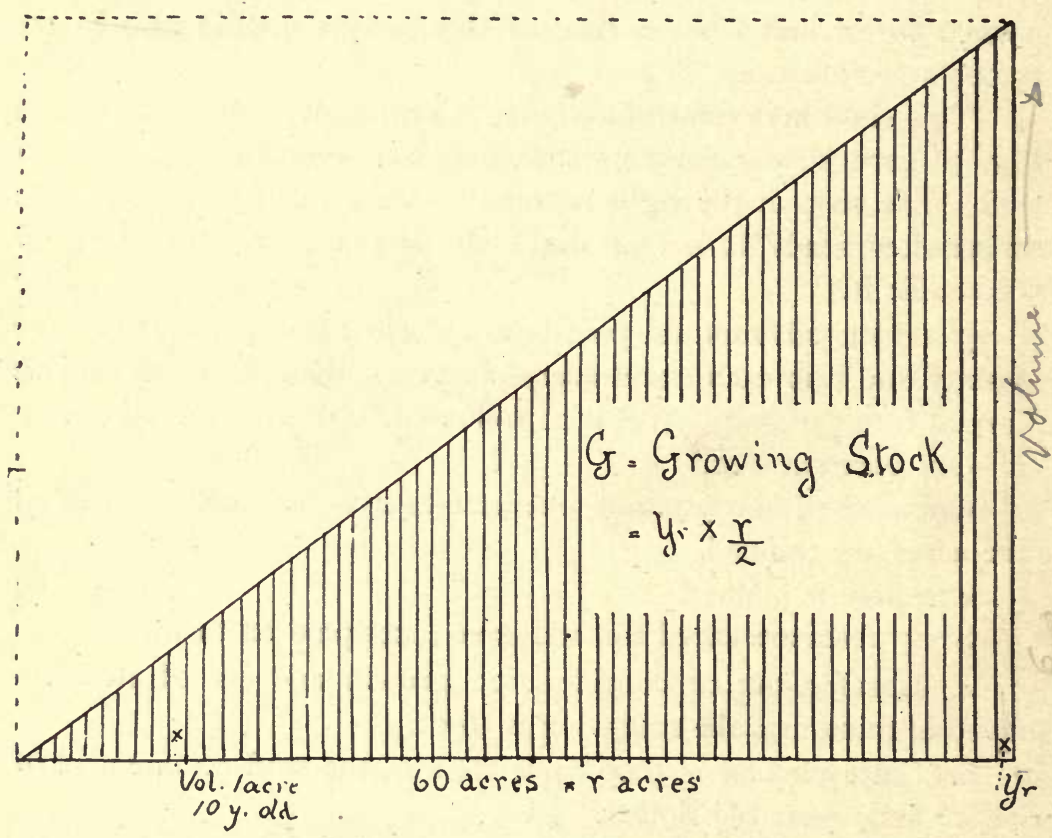

Figurf, 7. Diagram of a 60-acre Sample of a perfectly regular or Normal Forest. In this forest of 60 acres : $r$ is the Rotation or 60 years, $\mathrm{Yr}$ is the ripe timber 60 years old on one acre, ( $5600 \mathrm{cu}$. $\mathrm{ft}$. in our example) $\mathbf{G}$ is the Growing stock on 60 acres, varying in age from I to 60 years. This $G$ does not change, i. e., it is the same every year. Each strip represents the volume of timber or wood of one acre; and the volume is here assumed to vary directly as the age. The cut of ripe timber in each year is Yr equal to the growth on 60 acres. The cut in 60 years is $60 \times \mathrm{Yr}$ (The parallelogram in figure ) or twice the growing stock found at any one time. Thinnings are neglected in this consideration. 
f. The growth of 5600 cubic feet is the growth of ripe timber; it is made by sixty acres of growing trees and each acre makes or is assumed to make $5600 / 60=93.3$ cubic feet, the average yearly growth of ripe timber on one acre. This distinction of growth of "ripe timber" is made because the growth of the material taken in thinnings is omitted in this consideration.

g. Yearly cut of 5600 cubic feet from this sixty-acre forest forms a definite portion of the growing stock which may be expressed in per cent:

Cut as percent of Growing Stock $=5600 \times 100 / 168000=3.3 \%$, i. e., each year $3.3 \%$ of the Growing Stock is cut, and we can also say that the average growth of this growing timber is $3.3 \%$ in Volume. This conception was used by Hundeshagen in his Method of Regulation.

h. The Cut of 5600 expressed as a fraction of the Growing stock is :

Cut $=$ Growing Stock $/ \mathrm{I} / 2$ the years in rotation $=2 \mathrm{G} / \mathrm{r}=$ $168000 / 30=5600$, which is a useful conception applied in Von Mantel's Modification of Hundeshagen's Method of Regulation.

i. A glance at the Diagram Fig. 7 shows that if all of the sixty acres were stocked with forty-year old timber, the growth would be greater than it now is (forty-year old stuff being in the age of most rapid growth), and the amount of growing stock would be greater than in the regulated forest but it would not be possible to have a yearly cut, until the forest were again regulated to its present condition of Age Classes. Again the sixty acres might have all timber eighty or roo years old and so a very large amount of growing stock and capital and yet have a small amount of growth. and be unable to furnish a yearly cut without considerable sacrifice. This merely illustrates that it is only in the Regulated forest that Growth, Cut and Capital are properly balanced to supply best yearly cut and income.

5. Perfect regularity in matter of Age Classes, growth and Growing Stock is probably never attained in any forest. On the other hand it is quite surprising how perfect the regularity of Age Classes is coming to be on larger State forest properties of Europe and how readily and steadily this regularity maintains and perfects itself under well planned management. 
Fig. 8 illustrates the Regularity of Age Classes on Working Section No. II of the Sihlwald of the City of Zurich, a 780-acre tract of forest on rather steep mountain slopes and frequently injured by heavy snows, and therefore difficult to keep in well regulated condition.

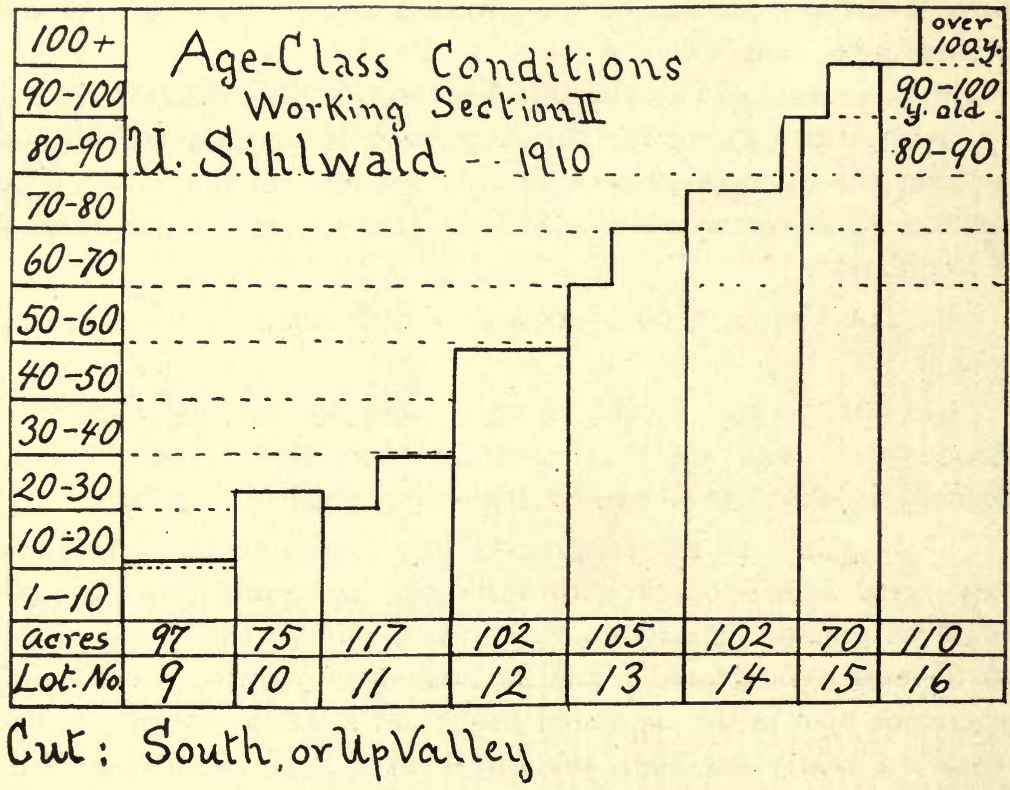

Figure, 8. Diagram of Age Class Conditions on Working Section No. II of the Sihlwald, near Zurich, Switzerland. This Working Section of about 780 acres, contains lots No. 9-16 and is ramarkably regular in its age classes in spite of much trouble from snow. Some lots contain timber of more than one 20-year age class; see lot II with timber in Age Class I and II. After Meister.

The forest occupies one side of a valley running North and South, cut is from North to South, division into eight lots, the method shelterwood. It will be noted that the age of timber on the same lot may or may not be uniform. Regulation by AustrianHeyer Method is prescribed officially. 


\section{Area Methods.}

I. Fixed Yearly Cut.

a. In Coppice.

L et Fig. 9 represent forty acres of Woods.

Method: Coppice.

Rotation: Twenty years.

Also assume that it is advisable, i. e., not too wasteful to start cutting in cutting area No. I ; next year in No. 2, etc., to No. 20. Regulation then simply divides this forty acres into twenty equal parts or twenty cutting areas, of two acres each, and plans to cut one of these every year.

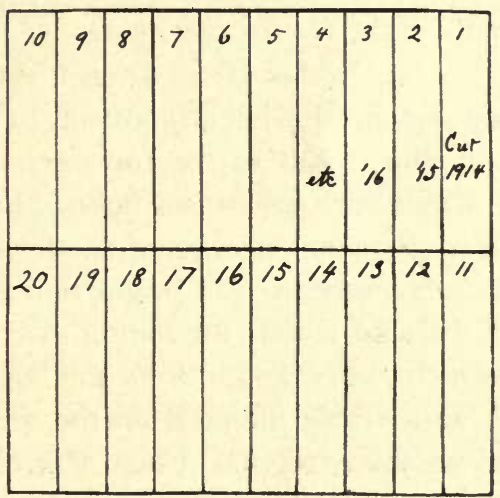

FIGURE 9. Diagram illustrating the Fixed Yearly Cut in Coppice. The 40-acre lot is divided into 20 equal or equivalent pieces, and one piece is cut each year, preventing all over-cutting and assuring proper age class conditions and maintenance of the adopted rotation.

In actual practice these areas may be monumented to save the trouble of re-survey, and asstire greater accuracy.

If this plan is followed, the small, coppice woods will be regulated in twenty years, and this regulation will have accomplished the usual objects; it will have:

Secured an equal yearly cut.

Perfect regularity of Age Classes.

A normal Growing Stock.

Maintenance of the twenty-year Rotation. 
If continued this plan will effectively prevent overcut and undercut, and always furnish material twenty years old or of desired age, size and quality.

\section{b. In Selection Forest.}

Assume: Forest of one Township (about 22000 acres).

Method: Selection.

Rotation: About I 50 years, judged by diameter of trees.

Period of Return: Twenty years.

Growing Stock: 5000 cubic feet per acre by actual cruise.

Level country, can log any part desired.

Regulation of Cut here divides the forest into twenty equal parts as in the case of Coppice, and plans to cut over about I 100 acres or about twenty-eight forties per year.

Since only part of the timber is cut at each return, the question at every cut is: how much, or what proportion of the stand should be taken? Generally this is left to the forester, whose good sense and knowledge of silviculture are relied upon. But in many cases this is unsafe and it becomes necessary to decide either on the quantity or volume to remove, or the proportion of the total stand which may be cut. In wild woods the matter is complicated by the great irregularity which exists, and also by the large amount of old, defective, crippled, undesirable material on the ground. Here it is often necessary to combine regular Clear Cutting, or Clear Cut with seed trees in the regular Selection Method, and much freedom must be of necessity allowed to the forester. The first going over generally takes over-ripe, ripe, and defective, it is a cut of ripe timber combined with an improvement cutting just as far as market and good silviculture allow and demand.

These conditions become better with each return, provided the overcut, which is almost sure to occur in many cases, does not hurt the forest to a point where reproduction is effectively prevented or seriously retarded.

In planning the first cut the stand to be left on the ground is the principal consideration, for the irregularity of the woods practically prevents more than a general figure of volume per acre or of proportion to leave and take. After several returns, a more definite regulation or volume check can be applied. 
For this Volume Check, in using the Fixed Yearly Cut Method of Regulation for the Selection forest, Hundeshagen's reasoning appears quite sufficient. This, as modified by Von Mantel permits the cut to take $2 \mathrm{G} / \mathrm{r}$ every year.

In our forest of 22000 acres, with a growing stock of 5000 cubic feet per acre or a total of

$5000 \times 22000=110$ million cubic $\mathrm{ft}$. of Growing Stock and a rotation of 150 years (decided upon) we could cut

$2 \times 110,000,000 / 1_{50}=1,460,000 \mathrm{cu}$. ft. per year.

Since this $I, 460,000 \mathrm{cu}$. ft. is cut on one-twentieth part of the township or I 100 acres, the cut per acre is

I, $460,000 /$ I I 00 or about I 300 cu. ft. per acre, actually cut over. A simpler way is: Cut $=2 \mathrm{G} / \mathrm{r} 20$ per acre at each return.

This per acre and with above premises:

$$
2 \times 5000 / 15020=: 1300 \mathrm{cul} \text { ft. }
$$

With a twenty-year return then the cut takes $20 / \mathrm{r}(2 \mathrm{G})=40 / \mathrm{r}$ G. With an ordinary rotation of Ioo years this would mean about $40 \%$ of the growing stock. From a silvicultural standpoint this would be a very heavy cut, and for rotations of roo years and less, a twenty year return is too long except for pure stands of intolerants. With a ten-year return and a cut of $20 \%$ a much better silviculture is possible. The amount or proportion to take out at each return depends on site, tolerance of species, market, etc. With intolerant pine more must be cut to enable reproduction; on poor sites less should be cut to avoid soil deterioration; with poor site and poor market, good silviculture must be sacrificed and more taken to make possible selling the stuff at all, etc.

From the foregoing it is evident that in the Selection Forest, Area Regulation is, of necessity, combined with a Volume Regulation or Volume check.

This method of logging over a definite area, and covering a property in a given time is perfectly practical and advisable. As in all cases of Regulation the property should be examined from time to time, preferably every ten years, and a plan adapted as the condi- 
tions of reproduction, growth, and of market suggest. Criticisms against this method are generally based on the false assumption that when a division and plan is once made, it must be followed without regard to changed conditions in the forest.*

Where Shelterwood and Clear Cutting Methods are employed, a division into smaller lots and into Cutting Series and also a more flexible plan become necessary. In the Selection forest the slow and easy ways of nature are relied upon, every lot receives a thorough cutting over every IO-I 5 years, mishaps in reproduction are reduced to minute areas and are left for nature to take care of. In clear cutting and planting things are forced, every acre must justify extra expenses and therefore every acre must be in a position where it can receive attention and care at any time. As soon as such a stand lags behind in growth the plan of regulation must provide for its removal. All this is not possible with a fixed yearly cut in a large property, and therefore this method has generally been replaced by the following, either in ordinary or limited form.

\section{Area Allotment.}

The following example illustrates this Method:

Plan for 1914-1933.

Area of Forest : 4000 acres.

Species: Spruce.

Method: Clear Cut and Plant.

Rotation: Ioo years, hence five age classes.

All one site, no "reduction of areas" necessary.

Yield per acre of Ioo-year old stand fully stocked: $9000 \mathrm{cu}$. ft.

Plan of Utilization: all stands in Age Class V (80-100 years old) and older, are considered ripe; also all defective stands and stands in poor condition of growth.

a. The first step is to prepare a table of Age Classes from the detail field examination. From this a table of allotment as follows:

* Such a misconception of Working Plans in general, and especially of Plan for Regulation of the Cut has led to much unnecessary controversy, and has often led the practicing forester to speak of the Plans as "Paper Jokes." See Michaelis, “Betriebsregulierung," Ig06. 
TABLE OF ALLOTMENT.

\begin{tabular}{|c|c|c|c|c|c|c|c|c|c|c|}
\hline Lot & Area & \multicolumn{2}{|c|}{ Age. } & \multirow{2}{*}{$\begin{array}{l}\text { Stock- } \\
\text { in I/Io } \\
\text { of } \\
\text { full. }\end{array}$} & \multicolumn{5}{|c|}{$\begin{array}{c}\text { Areas in Acres Alloted to Each } \\
\text { Period. }\end{array}$} & \multirow[b]{2}{*}{ Notes. } \\
\hline $\begin{array}{l}\text { Sub- } \\
\text { lot. }\end{array}$ & $\begin{array}{c}\text { in } \\
\text { Acres. }\end{array}$ & Years. & Class. & & $\begin{array}{c}\text { I9I4- } \\
\text { I933 } \\
\text { acres. }\end{array}$ & $\begin{array}{c}\text { I934- } \\
\text { I953 } \\
\text { acres. }\end{array}$ & $\begin{array}{c}\text { I954- } \\
\text { I973 } \\
\text { acres. }\end{array}$ & $\begin{array}{c}\text { I974- } \\
\text { 1993 } \\
\text { acres. }\end{array}$ & $\begin{array}{c}1994^{-} \\
2013 \\
\text { acres. }\end{array}$ & \\
\hline Ia & 40 & 70 & IV & 6 & & 40 & & & & $\begin{array}{l}\text { Ia. Quite } \\
\text { defective, }\end{array}$ \\
\hline Ib & 40 & 85 & $\mathrm{~V}$ & 8 & 40 & & & & & needs re- \\
\hline 2 & 80 & 30 & II & 9 & $\theta$ & & & 80 & & moval. \\
\hline 3 & 60 & 45 & III & 8 & & & 60 & & & 4a. Has \\
\hline $4 a$ & 30 & 75 & IV & 7 & & 30 & & & & $\begin{array}{l}\text { been open } \\
\text { a long time, }\end{array}$ \\
\hline $4 \mathrm{~b}$ & 50 & 15 & $\mathrm{I}$ & 9 & & & & & 50 & stuff large, \\
\hline 5 & 70 & 22 & II & 8 & & & & 70 & & can be cut \\
\hline 6 & 93 & 95 & $\mathrm{~V}$ & 8 & 90 & & & & & now. \\
\hline 7 & 65 & 104 & $\mathrm{~V}$ & 7 & 65 & & & & & Io. Very \\
\hline 8 & 40 & 35 & II & 9 & & & & 40 & & $\begin{array}{l}\text { poor stand, } \\
\text { insect-in- }\end{array}$ \\
\hline 9 & 55 & 12 & $\mathrm{I}$ & 9 & & & & & 55 & jured, re- \\
\hline 10 & 83 & $4 \mathrm{I}$ & III & 6 & & & 80 & & & move soon. \\
\hline
\end{tabular}

Etc., etc. This is continued for all lots of the forest.

Total have:

Should have:

\begin{tabular}{|r|r|r|r|r}
470 & I130 & 1050 & 930 & 420 \\
800 & 800 & 800 & 800 & 800 \\
\hline
\end{tabular}

b. A study of this table of Age Classes tells the forester:

That the forest is deficient in ripe timber and quite irregular, has plenty of middle age stuff, and lacks in young stands.

It also tells that certain stands in Age Class IV, like Ia and $4 \mathrm{a}$ can well be placed with ripe timber to be cut during coming twenty years. Also that the stand in lot ten though only forty-one years old should be cut and the land replanted.

c. In this way the forester has the whole situation placed clearly before him, and he is enabled to shift the stands and decide definitely what is to be cut during the next twenty years.

In this particular case he might shift all defective, all specially large timber from the second column into the first, so as to increase the cut of the next twenty years and avoid having too large a mass of stuff on hand in twenty and again in forty years from now. If the market takes stuff 6o-8o years old he might readily make 
up, in this way, a full 800-acre cut for the first period. Even then he would not prevent entirely some of the timber from going over the Ioo years, unless he is ready to cut over 800 acres in the period I954-I973.

d. In twenty years the forest is again examined and described; an entirely new plan is made; the stands are again allotted to various periods in keeping with the condition in which they are found in 1934 .

e. To this Regulation is normally added, an estimate of the amount of timber which the Stands finally placed in the first column (period 1914-I933) will furnish when cut. A common method is as follows :

Lot 6,90 acres, 0.8 stocked will be (presumably) Ioo years old when cut (middle of period) and will then furnish per acre: $0.8 \times 9000$ cubic feet or 7200 cubic feet per acre; total $90 \times 7200=$ 648,000 cubic feet. Of late the importance of Volume check has increased.

f. These estimates are not binding, area rules. If the cut for the period of twenty years is set at 760 acres, the yearly cut is $760 / 20=38$ acres.

g. The Method of Area Allotment was first clearly developed by Cotta; it has been modified in keeping with progress in the Regularity of State forests. Instead of insisting on a rigid continuation of a first plan, the plan itself is renewed at regular intervals (ten years Saxony, twenty years in other states). This method has outlived and displaced practically all others, and its superiority has induced the Prussian Government to continue it in official Instructions of IOI2.

In criticising this Method the mistake is ustally made of assuming that because the forester works out a few good tables which tell him exactly the age and condition of every stand, and because in making these tables he places the stands in different period columns, the Plan is binding for an entire rotation and the Method correspondingly rigid and useless. Part of this mistaken criticism is due to the fact that a century ago when forests were cheap, and money scarce, the administration, even such excellent men as Hartig, did not dare to hope that the forests would stand the expenses of re-surveys and Plan-revisions every ten or twenty years. 
That these Area Allotment Plans were often misused by narrowminded, domineering officialdom was no fault of the Plans.

h. Area Allotment is suited to any forest, to all conditions, provided there is market for the material to be cut, and for very irregular, mismanaged forests it has no equal. The very fact that it demands a careful study and placing before the forester (on paper) of every stand in the forest assures continued attention and care of every tract, a matter so easily overlooked and forgotten in a property of which the inspector or owner may not see large portions in a whole lifetime.

\section{Limited Area Allotment or Judeich's Method.}

"Judeich's Method" (Schlich); "Alters Klassen methode" (Judeich). "Bestands wirtschaft" of Judeich and other authors.

This is a method of Area Allotment; work in field and in office is the same as in the foregoing, except that the columns for periods 2-5 are left out entirely. Stands for the next twenty years (in Saxony ten years) are picked out as before, i. e., ripe and defective stands, and also some stands which must be cut to build new lines, etc., areas are added and if this sums up to more than the normal cutting area for the forest, reductions are made. In these reductions or additions the condition of younger stands is also considered.

Advantages claimed for this Method lie in the greater freedom of action for the forester. It is usually claimed that this Method only binds the action for the coming ten or twenty years, while regular Area Allotment is claimed to be binding for an entire rotation. This is not true.

In a very irregular forest; consideration of the younger timber is so important that some tabulation must be done to bring out the facts. Whether this table then stays in the plan or goes into the wastebasket may not be important, but, as Schilling correctly says, it ought to stay in the plan. This method of the Limited Area Allotment was the natural result of the rapid progress in forest regulation during the years $1820-1870$. The State forests of Saxony for instance had become so regular, work in the forest was so orderly and reliable that there was no further need of bringing into the Working Plan any stands which were not yet ready or in need of cutting and replanting. 
a. This Method gained favor among practicing foresters chiefly because it relieved them of some pressure from upper offices, and prevented somewhat the office insisting on the old plan, long after conditions of the woods made new provisions necessary. But all this has nothing to do with the Method itself. The new departure in the Prussian Instructions of 19I2 does all this much better by giving the forester himself the task of making his own working plans.

b. In Limited Area Allotment, Volume Check is generally demanded. The timber of all older stands, (ripe and near ripe and also defective) is estimated, and the Volume for the Period and each year set down in the Plan. This is merely estimate, and is chiefly intended to prevent great fluctuations in amount of stuff to be sold. Estimates even in Saxony are generally ocular when made for this purpose.

c. In a new country and on large properties, these Area Allotments can not be used without modification. It is useless to allot an area of forest to the period 1914-1934 when it is evident that none of the timber on this area can be sold. In these large properties, now practically restricted to the far West, accessible areas, or areas with market, must be temporarily separated into independent Working Sections if an Area Allotment is to apply.

\section{Volume Methods of Regulating the Cut.}

In trying to Regulate the cut by Volume the aim is to cut each year about as much as grows in the forest. In cases of wild woods where growth and decay practically balance, the cut also takes what the forest grows, i. e., the cut replaces decay.* In any case of Regulation by Volume the question arises: how much does the forest produce, or how much can be cut without cutting into the capital?

* It may be argued that by doing so the cut by man, and decay or harvest by nature taken together make an overcut, $i$. e., removes twice the growth. There is truth here, providing the forester has no choice of stands at all. If he has market for all, and is in position to get at old and defective stands, then the above reasoning is not truc. In any case, the importance of this decay is lessened year by year. Nevertheless, this matter is of some weight and indicates need for conservative estimate in setting the Cut in Volume. 
I. On a property of 20,000 acres of forest it is utterly impossible to measure accurately the amount of growth. And herein lies the weakness of all Regulation by Volume. In area regulation quantities are exactly known, if rotation is eighty years, the forester knows that a normal cut is $20000 / 80=250$ acres. Volume Regulation, on the other hand, is fortunate if Growing Stock is known within $15 \%$, and as to the growth, it can only be inferred from a comparison to known conditions (Yield Tables) or from stump- and stem-analyses and an estimate of how far these analyses apply in the actual Stand. In well regulated forests of Spruce in Saxony these estimates are amply reliable, in wild woods they rarely are.

2. For these reasons Volume Regulation is never more than an initial step and has given way to area regulation wherever forestry has made real progress.

But as a beginning it has value, and this is especially true under conditions where only portions of the forest have any market at all, and where large areas are in a formative state, of great and certain value in the near future and yet of no sale value at the present time.

3. When Regulation has decided the Volume which may be cut, say 15,000 cords from 20,000 acres, it has done practically all that Method of Regulation of the Cut can do and the rest is a matter of proper distribution, i. e., what stands to cut, and of silviculture. For this reason most Volume methods attempt only to estimate the amount of timber to be cut.

\section{Volume Allotment.}

The following case illustrates this method:

a. Plan for 1914-1933.

Area of forest 20,000 acres.

Species: Pine.

System: Clear Cut and Plant.

Rotation: 80 years, hence 4 age classes.

Site I $-20 \%$ of area, yield at 80 years $7000 \mathrm{cu}$. ft. per acre.

Site II $-50 \%$ of area, yield at 80 years $5600 \mathrm{cu}$. ft. per acre.

Site III $-30 \%$ of area, yield at 80 years $4200 \mathrm{cu}$. ft. per acre. All areas to be "reduced on plan:

Site I acre $=\mathrm{I} / \mathrm{t}$ acre "reduced" area.

Site II acre $=$ I acre "reduced" area.

Site III acre $=3 / 4$ acre "reduced" area. 


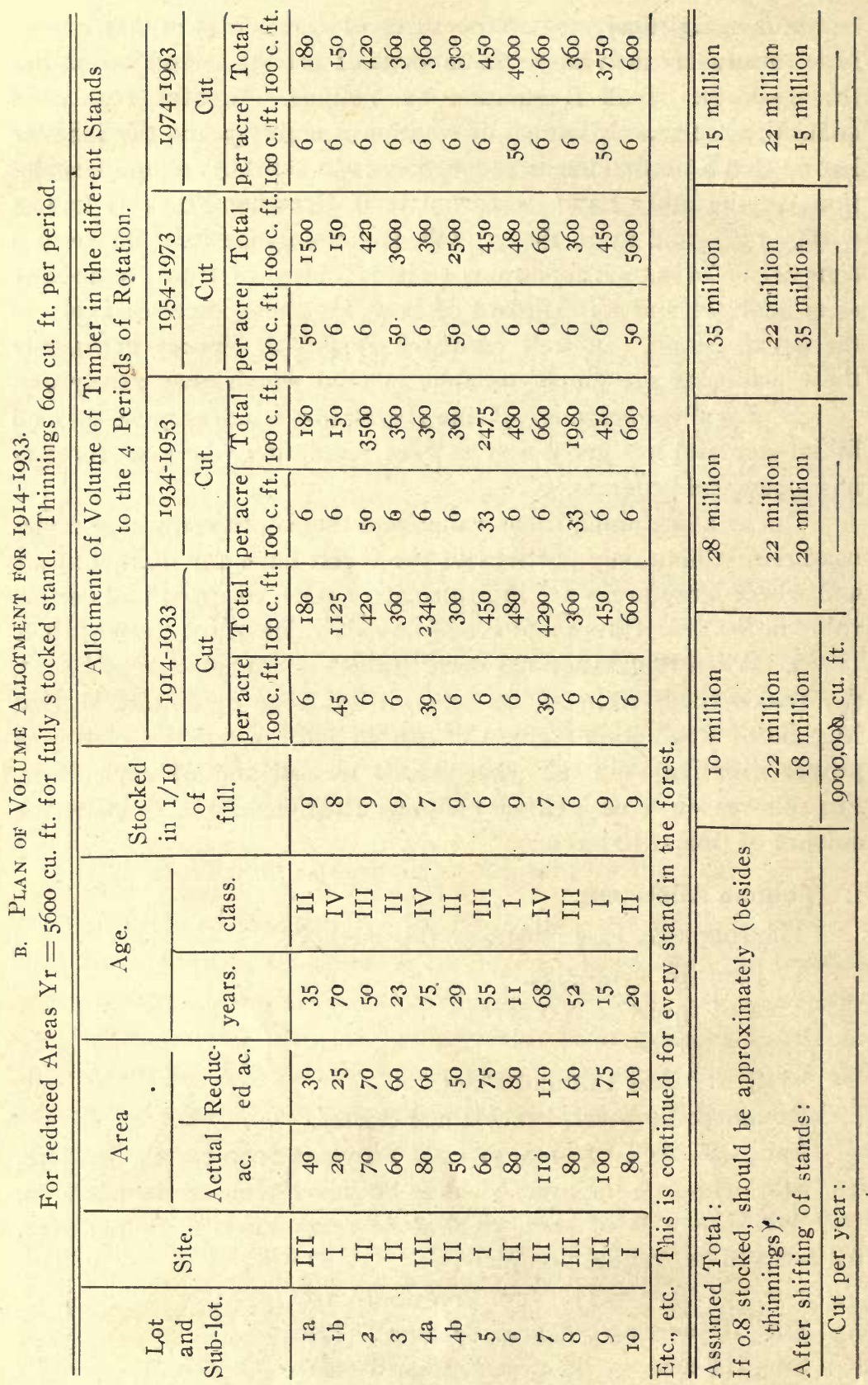


Plan of Utilization: All stands over sixty years old are ripe. and also all defective, and broken stands, and those with a current growth in value of less than $3 \%$. All thinnings are lumped at 300 cubic feet per acre for each thinning, these to come twice in every period, i. e., every ten years, so that each acre is credited with 600 cubic feet, of thinnings, for each period but none during the period in which the stand is planted.

c. From the above Plan it appears that the first Period (19141933) is deficient in ripe stuff, that the forest is quite irregular, that Age Class II is unduly represented. As in the case of Area Allotment, there is considerable shifting of stands from the second into the first period column. All defective, broken stands such as those of lots five and eight-are assigned to the cut of the next twenty years. In this way easily eight million cubic feet can be assigned to Period one, with the expectation that in 1934 a re-shifting of part of what is now Period No. 3 , into Period No. 2 will take place.

d. In the above plan the Cut of eighteen million cubic feet is definitely located throngh selection of ripe stands. But the forester has abundance of choice, as to the stands to be cut the first, second, etc., year. If at any time during the twenty years, or the life of this plan one stand appears more in need of removal than another there is nothing to hinder the forester. In this way every stand can receive attention and all timber cutting may be decided by financial or other considerations, provided always that the forest is in right condition, is properly divided into lots and Cutting Series, and receives proper care in silviculture. Since the timber alloted to the next twenty years' cut is not all cut in one year, but in twenty years, there is quite an appreciable amount of growth on this timber. This growth is usually added as a lump sum, it being assumed that the whole mass grows for one-half of twerty years as an average. So if twenty million feet are assigned and they may be assumed to grow at $2 \%$, the total mass is $20\left(1.02^{10}\right)=\mathrm{r} .22(20)=24.4$ million feet.

e. The Method of Volume Allotment as outlined above resembles Area Allotment. If well done, and properly revised every twenty years there is no reason why this plan should not work for 
greater regularity of Age Classes, and with this for a better forest business.

It works entirely with estimated quantities in its allotments, and it works in part with quantities or stands not yet even planted. This defect is easily overstated. The farmer who buys a farm, practically estimates the value of the farm on the basis of crops to be sown and harvested in the future.

This method was brought into prominence by Hartig, and made, for a time, the official method of the state forests of Prussia. It did good service, but was later displaced by the more accurate Area Allotment which works with quantities accurately measured and permanent.

f. Best critics usually charge that cuts of equal amount are not always desirable, that if much old timber exists there should be freedom to remove it, and also that estimates for the future are too uncertain. They also state that this method has more regard for the interests of the ownẹr and market than Area Allotment.* All through these discussions it is apparent that objections are based on conditions which are not necessarily parts of the Method, but are more mistakes in the application of the Method.

\section{Growing Stock Methods. Austrian and Hundeshagen.}

In these Methods the cut of timber to be taken each year is gauged by the amount of Growing Stock on the land.

a. Austrian Method and Heyer's Modification of this, or Heyer's Formula.

In wild woods with their irregularities of growing stock, and age classes, and their long rotations (life of tree) a particular forest may have more growing stock than is necessary to get the best growth under shortened (man-made) rotation. In such a case it is desirable to cut, not only the growth, but also to cut some of this surplus, stored-up wood capital, and gradually reduce the growing stock to a normal or proper amount, in keeping with rotation. This is done according to the following formula:

* See Martin, p. 209; Judeich, p. 356. 
Yearly Cut $=$ Yearly Growth + Actual Growing Stock - Normal Growing Stock divided by an arbitrary period of years, or

$$
\mathrm{Cut}=\mathrm{Growth}+\frac{\mathrm{Ga}-\mathrm{Gn}}{\mathrm{a} .}
$$

Also written: $\mathrm{Y}=\mathrm{Ir}+\frac{\mathrm{Gr}-\mathrm{Gn}}{\mathrm{a}} \ldots \ldots($ Schlich $) . *$

Where Ir is Real or actual Growth or "increment", Gr is real or actual Growing Stock and a is a period of years set arbitrarily in keeping with conditions found on the property.

The formula clearly shows the plan; the surplus, or amount of growing stock over and above normal, is divided by a and the $\mathrm{I} / \mathrm{a}$ part is added each year to estimated growth and is removed in the cut.

It also shows that if actual growing stock is deficient, as in badly overcut forest properties, the quantity $(\mathrm{Ga}-\mathrm{Gn}) / \mathrm{a}$ becomes negative, and the I/a part of this deficiency, is deducted from the estimated growth, the cut is lessened by this amount, and there is a saving up of growing stock to restore it to a proper or normal condition.

To supply concrete illustrations for these methods using the Growing Stock as a gauge in Regulating the Cut, the following premises are assumed:

I. Actual Conditions of the Forest to be Regulated.

$\begin{array}{ccc}\text { ARFA ACRES. } & \text { AGE YENARS. } & \text { STOCKED. } \\ 70 & \text { IO } & 0.9 \\ 130 & 20 & 0.7 \\ 60 & 30 & 0.8 \\ 200 & 40 & 0.7 \\ 150 & 50 & 0.7 \\ 40 & 60 & 0.8 \\ 650 \text { acres of woods. } & & \end{array}$

* In most books the Austrian Formula is written:

$$
\mathrm{Cut}=\mathrm{Growth}+\frac{\mathrm{Ga} \rightarrow \mathrm{Gn}}{\mathrm{r}}
$$

which would assume that in the Austrian form it was prescribed that the surplus must be spread over an entire rotation. And it is pointed out as a special distinction of Heyer's formula to introduce a as an arbitrary period in place of $\mathbf{r}$ or the rotation. Von Guttenberg declares this to be an error in his book (p. 154) and his reasons are convincing. 
2. Yield table. Pine, Site II, rotation sixty years, fully stocked. Thinnings not considered.

$\begin{array}{cccc}\text { AGE. } & \begin{array}{c}\text { YIELD PER } \\ \text { ACRE }\end{array} & \begin{array}{c}\text { CURRENT } \\ \text { CROWTII }\end{array} & \begin{array}{c}\text { AVERAGE } \\ \text { YEARLY GROWTH }\end{array} \\ \text { CULIC FT. } & \text { CUBIC FT. } & \text { CUBIC FT. } \\ \text { IO } & 460 & 46 & 46 \\ 20 & \text { I } 200 & 74 & 60 \\ 30 & 2250 & \text { IO } 5 & 75 \\ 40 & 3400 & 115 & 85 \\ 50 & 4500 & 110 & 93 \\ 60 & 5600 & 110 & 93\end{array}$

3. The Normal Growing Stock or Growing Stock on sixty acrcs of Normal or Regulated Forest:

a. By average yearly growth of ripe timber per acre.

By Diagram Fig. 7: $r=60$ y; $\mathrm{Yr}=5600 ; \mathrm{G}=5600 \times 60 / 2$.

Growing Stock $=168,000 \mathrm{cu}$. ft. on 60 acres, or 2800 per acre.*

b. Calculated from the above Yield Table by the formula $\mathrm{n}(\mathrm{a}+\mathrm{b}+\mathrm{c}+\mathrm{d}+\mathrm{e}+\mathrm{f} / 2)$, growing stock on sixty acres is:

$$
\begin{array}{llr}
a=460 & c=2250 & e=4500 \\
b=1200 & d=3400 & f / 2=2800
\end{array}
$$

On 60 acres: $14610 \times 10=146,100$; or 2450 per acre.

\section{Actual Growing Stock on this Forest:}

a. Calculated by Yield 'Tables.

$\begin{array}{cccr}\text { AREA } & \text { AGL } & \text { STOCKED } & \\ \text { ACRES. } & \text { YEARS. } & \text { IN O.I. } & \text { VOLUMF, IN CUBIC FEET } \\ 70 & \text { IO } & 0.9 & 70 \times 0.9 \times 460=28900 \\ 130 & 20 & 0.7 & \text { I } 30 \times 0.7 \times 1200=109200 \\ 60 & 30 & 0.8 & 60 \times 0.8 \times 2250=108000 \\ 200 & 40 & 0.7 & 200 \times 0.7 \times 3400=476000 \\ 150 & 50 & 0.7 & 150 \times 0.7 \times 4500=472500 \\ 40 & 60 & 0.8 & 40 \times 0.8 \times 5600=179200\end{array}$

Total on 650 acres $=1,373,800$ cubic feet.

Per acre Ga. or Actual Growing Stock $=21$ Io cubic feet.

* The usual calculations for conditions of this Growing Stock for fall and spring are left out of consideration.

$\$$ All figures rounded off in these problems. 
b. Calculated by Average Yearly Growth of Ripe Timber.

$\begin{array}{cccc}\text { AREA } & \text { AGE } & \text { STOCKFD } & \\ \text { ACRES. } & \text { YEARS. } & \text { IN O.I } & \text { VOLUNE IN CUBIC FEET. } \\ 70 & 10 & 0.9 & 70 \times 0.9 \times 10 \times 93=58500 \\ \text { I.30 } & 20 & 0.7 & I 30 \times 0.7 \times 20 \times 93=169200 \\ 60 & 30 & 0.8 & 60 \times 0.8 \times 30 \times 93=134000 \\ 200 & 40 & 0.7 & 200 \times 0.7 \times 40 \times 93=520000 \\ 150 & 50 & 0.7 & 150 \times 0.7 \times 50 \times 93=487000 \\ 40 & 60 & 0.8 & 40 \times 0.8 \times 60 \times 93=178200\end{array}$

'Total 650 acres: I 547900 cubic fect.

Ga. Actual Growing Stock per acre: 2380 cubic feet.

c. Comparing Gn, or Normal Growing Stock to Ga or Actual Growing Stock :

NORMAL ACTUAL

GROWING STOCK GROWING STOCK

PER ACRE PER ACRE

CUBIC FEET. CUBIC FEET.

Calculated on Average yearly Growth

of ripe Timber

Calculated by Yield Tables
$2800=\mathrm{Yr} / 2$

2450
2380

2 IIO

5. Normal Current Growth, or current yearly growth on sixty acres of regulated forest.

a. Calculated from the yield of the sixty-year old stand, the average yearly growth of ripe timber, the Current Growth is

$\mathrm{Yr} / \mathrm{r}=5600 / 60=93 \mathrm{cu}$. ft. per acre.

b. Calculated from Current Growth as given in Yield Table for fully stocked land.

AREA ACRES.

IO

IO

Io

IO

IO

IO
AGE, YEARS.

IO

20

30

40

50

60
VOI,UME IN CUBIC FEET.

$$
\begin{array}{r}
460 \\
740 \\
1050 \\
\text { I } 150 \\
\text { I } 100 \\
1100 \\
5600
\end{array}
$$

Normal Current Growth per acre: 93 cubic feet. 
6. Actual Current Growth per acre on the forest here considered, is as follows:

a. Calculated by use of Yield Table:

$\begin{array}{cccr}\text { AREA } & \text { AGE } & \text { STOCKED } & \\ \text { ACRES. } & \text { YEARS. } & \text { IN O.I. } & \text { VOLUME IN CUBIC FEET. } \\ 70 & \text { IO } & 0.9 & 70 \times 0.9 \times 46=2890 \\ 130 & 20 & 0.7 & \text { I } 30 \times 0.7 \times 70=6730 \\ 60 & 30 & 0.8 & 60 \times 0.8 \times 105=5040 \\ 200 & 40 & 0.7 & 200 \times 0.7 \times 115=16100 \\ 150 & 50 & 0.7 & 150 \times 0.7 \times 110=11550 \\ 40 & 60 & 0.8 & 40 \times 0.8 \times 110=3520\end{array}$

Total for 650 acres, $45^{8} 3^{\circ}$.

Actual Current Growth per acre: 70.5 cubic feet.

b. Calculated on basis of Average Yearly Growth of Ripe timber per acre:

$\begin{array}{rccr}\text { AREA } & \text { AGE } & & \\ \text { ACRES. } & \text { YFARS. } & \text { STOCKFD } & \text { VOLUMEIN CUBIC FEET. } \\ 70 & \text { IO } & 0.9 & 70 \times 0.9 \times 93=555^{\circ} \\ \text { I } 30 & 20 & 0.7 & \text { I } 30 \times 0.7 \times 93=845^{\circ} \\ 60 & 30 & 0.8 & 60 \times 0.8 \times 93=4460 \\ 200 & 40 & 0.7 & 200 \times 0.7 \times 93=13100 \\ \text { I } 50 & 50 & 0.7 & 150 \times 0.7 \times 93=9750 \\ 40 & 60 & 0.8 & 40 \times 0.8 \times 93=2980\end{array}$

Total 650 acres 44290 cubic feet, or 68 cubic feet per acre of Actual Current Growth.

7. Comparison of Normal Current Growth and Actual Current Growth :

NORMAL CURRENT ACTUAL CURRENT GROWT'F. GROWTH.

Calculated on basis of Average Yearly Growth of ripe timber Calculated on basis of Current

Growth as per Yield Table 93 cu. ft. 68 cu. ft.

In trying to regulate the cut of this forest by the AustrianHeyer Formula we have:

$$
\mathrm{Cut}=\mathrm{Growth}+(\mathrm{Ga}-\mathrm{Gn}) / \mathrm{a} \text {. }
$$


Actual growth is calculated (as under 6-b, see above) on basis of Average Yearly Growth of Ripe timber, in this case $68 \mathrm{cu}$. ft. per acre. Actual Growing Stock ( $\mathrm{Ga}$ ) is also calculated from Average Growth of Ripe timber (as in 4 -b of preceding tables) and is 2380 cu. ft. per acre. Normal Growing Stock per acre is $\mathrm{Yr} / 2$ or 2800 cu. ft. per acre (see $3 \mathrm{a}$ and $4 \mathrm{c}$ above). It is merely necessary now to decide on a, the period during which this regulation should take place. In this particular case there is not a surplus of Actual Growing Stock, but it is a deficit which should be corrected by saving in the cut. The large area of twenty year old and of forty and fifty year old stuff and the fair condition of these stands (stocking $7+$ ) would indicate that there is no great need of saving heavily. For this reason the saving up is spread over an entire rotation and it is decided to make $\mathbf{a}=\mathbf{r}$ in this case. Using the above data, then, the Cut $=68+(2380-2800) / 60=68-7=6 \mathrm{cu}$. ft. per acre, and for the forest of 650 acres the Yearly Cut is $39,650 \mathrm{cu}$. ft. per year.

The Austrian Method or Formula was not an invention of the forester, but of an office man, and was introduced not for regulation but for valuation of forest properties.

It does not presuppose or prescrice any particular method of silviculture, division, regularity of age c'asses, or any particular order or sequence of the cut. The cut may be made at any point.

But this method does not forbid forest division and order in the work, and it is no fault, therefore, of this method that such improvements are not prescribed in any particular plan.

It can be applied to any forest and under any conditions, and is particularly well suited to irregular wild woods in large properties and to the Selection forest. It will at once set a reasonable cut, prevent overcutting and work in the direction of order, and greater regularity, not only of Growing Stock in Volume, but also of Age Classes. Proof of the value of this method is given by the city forests of Zurich where this method has long been in use, is prescribed officially by the kanton government, and has led to perfect regulation under the master hand of Director Meister. In these forests in 1882 the period a of the formula was set at $r$ (rotation) or ninety years for Working Section I; at forty years in Working Section II ; and only twenty years in Section III of the Sihlwald. 
The fact that this method, like all volume methods, works with estimated quantities, and ganges such quantities for the future is not nearly as serious as appears at first. Just as in farming, average yield per acre for twenty or more years can very well be estimated and is relied upon in setting a value on the farm and its business, so it can be relied upon in forestry, where the crop is far more independent of the seasonal fluctuations of growth. The important point here is not that estimates be accurate, though of course this is desirable, but that the plan is followed faithfully and that the property is re-examined and the plan revised at regular intervals to suit changed conditions. For it can never be emphasized too much that the forest is a living body, and reproduction, growth, cut and decay bring decided changes every year, so that no plan can be relied upon for any length of time.

In applying the Austrian-Heyer Formita to Wild Woods and to Selection forests, actual growth and Normal Growing Stock are obtained from Yield table studies, and Actual Growing Stock can only be obtained by cruising the property.

That this method or formula is not applicable in the case of a small forest in which the entire growing stock is unripe young stuff is self evident. In such a case there is nothing to do but wait untit the stuff is ripe to cut. 'To cite such cases in evidence of the deficiency of the Austrian Method can not help science or practice.

It is also evident that in the case of large wild woods properties some errors must creep in wherever large bodies of old defective stuff can not be sold. In such cases there is not only a cut, but there is also a natural harvest or decay which needs to be considered. But such difficulties are of minor importance and can be largely eliminated by separating portions of the property which have no market and simply treating them, temporarily, as separate Working Sections not yet ready for Regulation of Cut.

b. Hundeshagen's Method and Von Mantel's Modification of this. Hundeshagen assumed that the relation of Growth (or Cut) to Growing Stock should be the same in the unregulated forest as in the regulated one. His formula:

Cut in ordinary forest/Growing Stock of this forest $=$ Cut in Regulated Forest/Growing Stock in Regulated Forest, or Cut/Ga = $\mathrm{Yr} / \mathrm{Gn} \therefore \mathrm{Cut}=\mathrm{Ga}(\mathrm{Yr} / \mathrm{Gn})$. 
$\mathrm{Ga}$ is based on actual inspection of every stand, and either estimated by cruising, or else as in $4 \mathrm{a}$ of above tables, by ascertaining age and condition of stocking and then computing volume by yield tables.

Gn is obtained by summation of Yield table as done in $3 \mathrm{~b}$ of above examples.

$\mathrm{Yr}$ is the stand of one acre $\mathrm{r}$ years old as per yield table.

According to the above premises the cut in the small forest there assumed would be :

$\mathrm{Cut}=2110(5600 / 146000)=2110(\mathrm{I} / 26)=\mathrm{Ga}(\mathrm{Cut}$ on $\mathrm{r}$ acres; 'Stock on $\mathrm{r}$ acres $)=2 \mathrm{I}$ IO $(3.8 \%)=80 \mathrm{cu}$. $\mathrm{ft}$. per acre.

In this case then the yearly cut would take $80 \mathrm{cu}$. ft. per acre or $650 \times 80=52,000 \mathrm{cu}$. ft. in all. Von Mantel evidently going on the assumption that a little more or less in the estimate would not change results in ordinary cases decided to use Normal Stock as calculated from $\operatorname{Yr}$ and $\mathrm{r}$, i. e., $\operatorname{Yr} \times \mathrm{r} / 2$; in our case $5600 \times 60 / 2=$ I68,000 cu. ft. for 60 acres.

In this way the formula is simplified to:

$\mathrm{Cut}=\mathrm{Ga} \mathrm{Yr} / \mathrm{Ga}=\mathrm{GaYr} / \mathrm{Yr} \times \mathrm{r} / 2=\mathrm{Ga} 2 / \mathrm{r}$

which merely follows out logically the assumption of Hundeshagen; and is based on the fact that in a regulated forest the growth in the forest during rotation equals twice the growing stock found at any time on the land, as stated under Normal forest.

In the assumed case then: $\mathrm{Cut}=2 \mathrm{Ga} / \mathrm{r}$ or

$\mathrm{Cut}=2 \mathrm{I}$ Iо $\times 2 / 60=70 \mathrm{cu}$. ft. per acre, or about Io cu. ft. less than by the regular Hundeshagen calculation.

Von Mantel's Modification of Hundeshagen's formula is a very useful devise to start the regulation on large wild woods properties. It adapts the cut to the actual growing stock on the land, whether this is in excess or below normal.

In large properties stocked with pure stands of intolerants, Western Yellow Pine, Lodge Pole, etc., where the stands are largely even aged and where some of the Age Classes are practically wanting, application of either the Austrian or Hundeshagen Method needs a careful consideration of actual existing conditions.

What has been said with regard to the foregoing methods applies here. This method merely estimates the proper cut to make 
and does not consider other provisions of the plan. But this fact does not prevent a proper development of forest division, order in cutting, or necessary revisions with their surveys and estimates of all parts of the forest.

This method recommends itself by simplicity, is adaptive, and fully competent to develop a well regulated forest. Nevertheless, this method never gained favor and was never employed by any of the State forest Departments so that it stands today without any important results or experience, and merely with an academic history in text books.

c. Combined Methods. Of these the Combined Allotment where the table was made sufficiently large to accommodate columns for areas and for volumes has been the most important. Since this, in actual practice has long changed to the Area Allotment with volume as a check, there is no occasion to go into it further.*

d. "Diameter Limit" as a Method of Regulation. Diameter limit has been recommended and applied in some of the early efforts in forestry, it has become very generally known, appealing, as it does, to the man in the woods. Its object is not really Regulation, but merely an effort to preserve the forest from immediate devastation.

For this purpose it has served well, at least in a few cases, and is perfectly suited to help in most forests. But good silviculture alone condemns any rigid application of diameter limit for any real forestry, since the runt or small tree is often older and more worthless to keep in the woods. If this runty stuff is to be cut, then the enterprise is no longer based on diameter limit. As a means of Regulation of Cut it fails because it is based on the mistaken assumption that diameter and age are proportional, an assumption always wrong in any forest, regardless of care, and wrong to an extent of $30-50 \%$, i. e., in the eighty year old stand, even in a well cared for forest, the largest tree differs from the smallest tree by easily 30 $50 \%$ in diameter. Even where this diameter limit is used, either an area regulation or a volume regulation such as V'on Mantel's should be added.

* For complete list of the many methods published at different times, see Recknagel, "Theory and Practice of Working Plans." 
In the Selection Forest, diameter limit is used to assure, approximately, the desired rotation. Here the assumption is that the good trees, forming the harvest part of the cut, (in distinction to stuff cut for improvement and thinning) are of a certain size at a particular age, an assumption amply accurate for the purpose in hand.

\section{Application of Methods of Regulation of Cut in the United States.}

Regulation of the Cut in amount (Area or Volume) is very important in development of any Forest property to prevent unreasonable overcutting which could defer any desired regularity of income for a long time and bring permanent injury to parts of a forest. But it is not as important as is good protection and silviculture and a suitable division of the forest, for these together with any degree of orderly sequence of cutting will in themselves work in the direction of regularity and will in all forest properties largely replace Regulation of the cut and necessity for special measurements and calculation, just as they have done in parts of the old world. In time Regulation must simplify itself in any good forest into the task of going over the property about once in twenty years, and picking out the stands either ripe enough to cut, or stands in bad condition and therefore in need of cutting, and assigning these to the next twenty years' work, area indicated by the rotation adopted. If this is 100 years, then approximately one-fifth of the entire forest should be assigned to a period of twenty years.

But in the present beginning stages of forestry, such simple and satisfactory procedure is not possible. More than $75 \%$ of our large forest areas are not even accessible and assigning an area here to a particular time, can have no meaning. For this and other reasons it is necessary to use other methods, and it is interesting to see how these may apply to particular forms of forest and conditions, as they now exist in the United States. The following suggestions are general.

\section{Regulation in the Woodlot.}

It may seem pedantic to speak of a regulation of the cut in a twenty or forty acre woodlot. But experience in the woodlots of our country shows clearly that not only are such woodlots suffering 
for want of better silviculture, but also from a lack of orderly cutting. Whether hardwood in selection forest, coppice, or clear cut and planting, perhaps the three simplest and best methods for ordinary case, such a woodlot is bound to gain in value by some regulation. In our ordinary hardwood lot, the method is usually a mixture of coppice and selection, but the common way of cutting is to overcut at the edges, and neglect to cut the interior, so that most of them appear like half cleared pastures along their border, devoid of protection against wind and sun, while at the interior there remain old, large crowned, usually defective trees which should have been removed long ago. For this reason growth in these lots is small, in spite of good quality of site, and it is small in quality as well as volume.

Simple regulation by fixed yearly cut, with each year's cut marked by posts is satisfactory, and will, if properly followed lead to better and larger growth and assure a yearly cut of value. A forty acre lot in selection method might well be divided into ten four acre lots, one lot to be cut over each year. The amount to take out should, ordinarily, not exceed one-fourth of the total volume. If it is estimated that the woodlot has thirty-six cords of material per acre, all told, then the cut should take about nine cords of this. This nine cords should be made up of old, ripe stuff and defective material. If there is quite a large amount of this old and defective stuff, it is better to take a smaller area, cut heavier and plant up all openings made hy removal of the old stuff.

\section{Regulation in the Large Selection Forest.}

a. In Level Country. The assumption here is a forest like those of the Great Lakes Country with market for everything, and simple winter, snow and ice-road logging.

Here also a simple Fixed Yearly. Cut Regulation will prove perfectly satisfactory. The areas in such a case need not be marked on the gound, it is sufficient to indicate each year's cut on a map or plat showing the property, and this cut may very well follow present logging ways of cutting by forties. A volume check is needed, and if a twenty year return and 120 year rotation is decided upon, about $30 \%$ of the volume of the growing stock may be taken. In such a case, the first cutting over of the property should not adhere too rigidly to the volume check, but leave quite as much freedom to 
silviculture as market permits. With the selection method to follow, it is quite immaterial where the cut begins, whether in one or several places, and what its rate of progress at any point. Similarly it is permissible to ignore conditions of types and future Working Sections as well as a division into Cutting Series.

In a property of this kind simple Regulation by Volume will answer. If Von Mantel's formula is used and rotation is set at I20 years and period of return at twenty years the formula as in the above case provides a cut of alsout $30 \%$ of the growing stock on every acre cut over. For example: rotation 120 years; period of return, twenty years; growing stock forty-five cords per acre, all told; area of forest 10,000 acres.

The formula :

$$
\text { Yearly Cut }=\mathrm{G} 2 / \mathrm{r}=2 \times 10,000 \times 45 / 120=7500 \text { cords per }
$$
year.

But since the plan calls for a return every twenty years, this 7500 cords is cut from $\mathrm{I} / 20$ of the area or from about 500 acres. In this way Regulation though really by volume, at once involves an area consideration and takes the form of a combined method, just as in the above case where regulation started with fixed yearly cut, and merely used Volume as a check.

If in the foregoing plan a definite period of return is left out, regulation of the cut merely prescribes that it take 7500 cords and does not specify that this come from 500 acres, but permits that a heavier or a lighter cut per acre be made. While in this form it becomes strictly volume regulation, yet in actual practice the plan of silviculture also sets its limitations and if the forest is fairly uniform, the forster naturally cuts different tracts in about the same way, and covers nearly the same area each year. But this again leads to a more or less uniform period of return and with this to a combination of Volume Regulation and Area Regulation.

With a forest of hardwoods and Hemlock on good sites, as is here considered, the question arises: should not this good site be cleared at once and some more profitable species replace the hardwoods? No doubt this is true. But to the owner of 1o,ooo or 20,000 acres this would mean quite a sacrifice in growth and in valuable young growing stock. A much better way for the owner who wishes to transform this Wild Woods into a paying forest 
business, is to cut it over in the manner outlined above and plant some Spruce and White Pine into the open spots each spring and merely add to the valuable stuff, rather than destroy and replace it. On areas where old defective stands cover practically all the ground, and where little of value is left after logging, the land should at once be planted to better species. With change later on, from Selection to Clear Cut, Regulation should change from Fixed Cut to Area Allotment.

b. Regulation in Large Selection Forest in Mountains. In forests like those of the White Mountains, Maine and the Appalachians, logging normally starts in the lower valleys and proceeds up the valley and its branches. In this way the point of beginning and the order of progress are prescribed by topography. Usually, too, the rate of progress is not altogether arbitrary, and in cases where the timber must be driven on small streams, it is distinctly limited.

This situation is often complicated by the fact that only conifers can be marketed, as in the northeast or only part of the hardwoods, as in the southern mountains, etc.

Example: area 30,000 acres; forest of spruce, more or less mixed with hardwoods, the latter not yet marketable; method: selection with a rotation about 120 years, indicated by a thrifty ten inch tree. In this case good silviculture must endure, at least for the present, a very unsatisfactory situation and cut the species to be favored, and leave the very species to be restricted in possession of the ground. Good regulation, too, is violated, since more than $50 \%$ of what is ripe and in need of cutting must be left on the ground for lack of market or rather of roads.

In cases of this kind ordinary logging methods select each year the area to be logged, develop on this area the necessary roads and go ahead. It is a fixed yearly cut without a plan for the future. Regulation here needs only to improve on this method, long followed, prepare a proper set of reliable maps, select "fixed yearly cuts" on the map first and in the field afterward, and plan these cuts for the entire property. In all likelihood this plan would need modification for the first and second going over the property, but it would certainly be a great step toward an orderly development of this property to have at the office reliable maps and a definite well 
based plan, and in all cases would be far better than to leave this most important of all tasks to the woods foreman who happened to be on the job that particular year.

Volume check here should be waived and the matter left to good silviculture. In pure stands of Spruce danger from windfall alone demands a light cut; in hardwoods the cut should try to favor reproduction of Spruce at the expense of hardwoods, and certainly leave enough Spruce to assure this, or else assist artificially. In all cases, if the selection method is used, the cut should leave a fair stand sufficiently resistant to wind and snow injury, and especially avoid large areas cut clear, and even smaller ones (ten acres and over) unless these can at once be re-stocked by planting.

Properties such as are assumed here are not rare today (I9I4) and it is surprising how large an amount of timber still is left to die and decay in the woods of the New England States, simply for lack of roads and railroad facilities. If part of the money taken from these properties were put back for their improvement it would be an easy matter to change this condition.

\section{Regulation in the Southern Pinery.}

A fine climate which makes even lean lands excellent forest sites with remarkable growth together with pure stands of intolerants, calls for the Clear Cut Method of silviculture. To secure best results and avoid serious and avoidable loss, the forest should be surveyed, divided preferably on the United States survey plan; it should be carefully examined and described and the plan should bring and keep the exact status of every forty before the forester and the owner.

This is done better by the plan of Area Allotment which deserves preference and in time will undoubterlly displace any other in this region. In the beginning, when numerous ripe stands can not possibly be reached during the first "period" of twenty years, these ripe stands are placed in the plan to suit conditions.

On properties having a very large amount of overripe stuff, usually accompanied by great masses of defective material, it may prove advantageous to cut the property. or at least parts of it over on the Selection plan. In this case volume check may well be left out and the degree of cutting left to silviculture. 
In these properties of the Southern Pinery, danger from insects must be considered and may require immediate attention in regulating not merely the cut in Volume kut also in location, i. e., attend to a proper distribution of the Age Classes, or stands of different age, and with this of Cutting Series. For it is just in these forests of rapid growth where changes in conditions come fast and often, and where every stand must be in position for independent treatment.

\section{Regulation in Lodge Pole Pine.}

Typical case: property of 500,000 acres ; Rocky Mountain country, largely plitean and large slopes, fairly accessible. Forest practically pure Lodge Pole; at higher altitudes a timber-line country with Engelman Spruce, often mixed with Lodge Pole, primarily protective forest. Considerable areas of barc, grazing lands. Market is good for railway ties, poor for lumber. The following conditions hold:

a. 'Iotal Area: 500,000 acres.

b. Area in woods about 400,000 acres; rest in prairie and waste.

c. Conditions of wood lands as per detail cruise by forty acre lots :

I. Cut-over lands, and burns practically bare now, 41,000 acres with reprouluction expected in next twenty years.

2. "Jack Y'ine", stuff below 4 " d. b. h. and $25 \mathrm{ft}$. in height 142,000 acres.

3. Poles, average $5^{\prime \prime}$ d. h. h. $\left(4-6^{\prime \prime}\right)-6,000$ acres.

4. Stands of Larger Poles 6-10", 80-120 years old-none.

5. Merchantable 'Timber 120-250 years old-194,000 acres.

d. Rotation is set at 200 years, (approximate average age of mature timber), and assumes that technical rotation continues to be based on size required for ties. On this basis the above conditions may be stated thus:

PER CENT SHOULD BE IF OF $\triangle R E A$. REGUIATED.

Bare areas to reproduce in next 20 years..... ro r $9 \%$

Age Classes I and II, I-40 years old stuff $\ldots . .35 \%$ I $8 \%$

Age Classes III and IV, 40-80 year old stuff... $6 \% \quad 18 \%$

Age Classes V and VI, 80-1 20 year old stuff.. O\% $18 \%$

Age Classes VII and X, I $20-200$ years or older. $48 \% \quad 36 \%$ 
From this statement it is evident that the property has too much bare land and young stuff, is practically without middle aged stock, but has an abundance of ripe timber. If a continuous supply is to exist here Regulation must get along with what timber there is in age class VII and older, until the young stuff is sufficiently large to cut. The probability is that rotation is set higher by about 20-40 years than is absolutely necessary, even for average site.

e. Sites were not differentiated in the examination of the property.

f. Growing Stock of merchantable material on the 194,000 acres of old woods is estimated at 3200 million feet b. m. over $\mathrm{ro}^{\prime \prime}$ d. b. h. or about i6,000 feet b. m. per acre. Good (fully stocked) stands on average site run 25,000 feet b. m. Volume of young stock is neglected in the calculation.

g. Actual average growth of ripe timber is set at $16000 / 200=$ $8 \mathrm{oft}$. b. m. Normal average growth of ripe timber at $25000 / 200=$ I $25 \mathrm{ft}$. b. m. Actual Growing stock per acre is 3200 million ( $\mathrm{ft}$.)/ 400,000 (acres) $=8000 \mathrm{ft}$. Normal Growing Stock per acre is $25000 / 2=12500 \mathrm{ft}$.

h. Plan of Cutting, i. e., the silvicultural plan is to cut the land over by the selection method, taking about $30-35 \%$ of the stand of any one acre, the rule being to "leave a forest cover." Later on. (within 50 years) it is expected that the Clear Cut system with seeding from the side can set in.

i. Regulation, for the present, must set a reasonable Volume check, i. e., it must determine the amount of timber which may safely be cut without over-cut, and with full regard for the conditions, particularly irregularity of age classes, and assure a sustained yearly cut from the property. Several methods are tried, as follows, and their results compared.

j. Fixed yearly Cut, modified. To apply this method, the I89,000 acres of bare land and young stuff are left out of consideration for the present since no cutting can be done on these lands. For the other 194,000 acres the plan provides for a 40 year return, a yearly cut of $194,000 / 40$ or about 5000 acres, and silviculture indicates a cut of $16000 / 3$ or about 5 M. ft. per acre. Total Cut: 5 M. $\times 500$ (acres) or 25 million feet b. m., to be cut wherever 
timber sales can be made, and thus the particular areas to be decided upon from time to time. It is expected that long before the end of forty years, the property is again examined and a new plan is made in keeping with conditions as they will then exist.

k. Hundeshagen's Method with Von Mantel's modification. Here the $\mathrm{Cut}=2 \mathrm{Ga} / \mathrm{r}$.

For our case: $\mathrm{Cut}=2 \times 3200$ million $\mathrm{ft} . / 200=32$ million per year. On this plan the present supply would be cut in Ioo years and at that time little material over i 20 years old conld be expected to exist on this property. For this reason the thirty-two million must be regarded as about the maximum cut allowable.

\section{Austrian Method, or Heyer's Formula.}

$$
\mathrm{Cut}=\text { Growth }+\frac{\mathrm{Ga}-\mathrm{Gn}}{\mathrm{a} .}
$$

In this case : $\mathrm{Cut}=80+(8000-12500) / 200$, or about : $80-$ $22=58 \mathrm{ft}$. per acre.

For the property: $5^{8} \times 400,000=23.2$ million feet.

It will be noticed that, in spite of the large amount of old stuff, actual Growing Stock is smaller than normal Growing Stock, so that it is not a surplus, but a deficit which must be spread. Since there is no. special reason for spreading this over a shorter period, it is distributed over an entire rotation, i. e., a is made equal $r$.

m. Hufnagle's Method for smaller properties, might also be used here with some modification. He prescribes estimating the volume of stuff older than half the rotation and spreading this volume over the period, i. e., over half the rotation. In our case this might well be used:

Growing stock older than $\mathrm{r} / 2 \mathrm{r}=3200$ million $\mathrm{ft}$.

Time before the younger stock will be ready for the axe about 125 years, and for this period the merchantable timber should be made to last. Hence :

Yearly Cut $=3200$ million $\mathrm{ft} . / 125=25.6$ million $\mathrm{ft}$.

n. Good silviculture demands that as far as possible oldest and most defective stands should be cut first. But on a property of this kind such requirement must often be disregarded for lack of opportunity to sell the material. For this reason the cut will be 
accompanied for some time by a large amount of unavoidable loss in old and defective stuff, and it seems advisable to keep the cut correspondingly a little below rather than above that worked out by the above calculations.

o. Whether, in this plan of Regulation, the figure of twentyfive million per year or thirty-two million is used, is not of very great consequence. In any case the cut should follow the plan faithfully, and if it does, there is little danger of serious overcut. But this plan must never continue longer than forty years without some revision, a new inventory, a new study of the situation.

p. When once the larger part of this property is accessible by roads and railways, so that the selection method can. give way to clear cutting, regulation may well divide this large forest into several working sections, and certainly cut out the timberline country as a permanent selection forest. Then also, regulation of accessible portions should change from any one of the above forms to an Area Allotment based on the forty acre tract subdivision of the forest. With this, there must also come development of well planned cutting series, preferably of a single lot in level country and on easy slopes, but of lots to fit topography in all steeper and more broken country. Injury from wind and snow in L,odge Pole as well as great danger from fire will recommend these independent stands.

\section{Regulation in Western Yellow Pine.}

The property here considered had about the following conditions in I9I2.

a. Area: Nearly one million acres.

Topography: plateau and easy slopes prevail, average altitude 4500 .

Site: climate, moderate; rainfall about $30^{\prime \prime}$. Snow deep, over three feet; Ioo days sleighing; summers warm and dry. Soil, mostly deep, pumice sands, quite fertile.

b. Timber: largely in even age (all-old) stands; much overripe stuff "spike top." Only about 20,000 acres of young stands on lands, cut over in last forty years.

Growth: the Ioo year tree is normally about $18^{\prime \prime}$ d. b. h. and Ioo feet in height for dominant stuff. Fully stocked mature stands: 
40,000 feet on good site, and estimated 30,000 feet for average site. of property. Net growth is zero, probably negative.

c. Preliminary Cruise only. According to this, the property has about eleven billion feet 1 .. $\mathrm{m}$. of merchantable stuff or about I2,000 feet average per acre, over fourteen inches d. b. h.; timber large, $5^{-6} \operatorname{logs}$ per tree, and $2.6 \operatorname{logs}$ per M. ft.; cuts very sound; timber long lived; natural rotation over 250 years.

1. Market just beginning in its development. Only market for saw timber, preferably large stuff. Can well afford to take as little as 4 M. ft. per acre, i. e., it pays to $\log$ for this amount.

e. Danger from insects, bark beetle in o!d stuff and also from fire: many lightning fires here.

f. Plan of cutting so far: Clear Cut, with few seed trees; expect to bring up the cut to over one hundred million feet per year within five years.

s. In making the prelininary plans the following questions arose:

1. If one hundred million feet are cut yearly on clear cut plan, it will take over 8000 acres per year. If these cuttings range themselves side by side twenty years' work will clear a solid area of about I ho.oo acres, which will, or is expected to grow up to young stands of pine. Such an area of young pine would be a certain loss in case of fire.

2. If one hundred million feet are cut in this way, it will take over 100 years to cover the property. In this time a great deal of the more remote timber will have died and become a total loss. Part of this loss is unavoidable, but may be lessened by a more speerly cutting over of the entire property.

h. Suggested Plan of Regulation:

I. Cut on selection plan to allow free hand to purchasers to select areas: cut only $30-35 \%$ of total ; cut clear only in exceptional cases and in areas no larger than necessary to remove clumps of defective, over ripe stuff unable to hold over for another cut.

2. Raise the cut as fast as possible to that indicated by the growth, the growing stock now on the ground, and a rotation of I 20 years, this latter assumed long enough to produce saw timber of suitable size. 
3. Bases of estimating the proper cut.

Actual Growing Stock:

$12,000 \mathrm{ft}$. of merchantable size, regular cruise.

4,000 ft. of non-merchantable sizes by estimate or comparison to merchantable stuff.*

Total 16,000 ft. b. m.

Normal Growing Stock $\frac{30,000 \mathrm{ft} .}{2}=$ I 5,000 ft. b. m.

Actual Growth $=\frac{\mathrm{I} 6,000(\mathrm{ft} .)}{\mathrm{I} 20(\text { rotation })}=\mathrm{I} 33 \mathrm{ft}$. per acre and year.

4. Von Mantel's formula.

$\mathrm{Cut}=2 \mathrm{G} / \mathrm{r}$.

In our case: $\mathrm{Cut}=\frac{2 \times \mathrm{I}, 000 \text { million }}{\mathrm{I} 20}=$ about $\mathrm{I}$ So million.

5. Regulation by the Austrian Method.

Cut: Growth $+\frac{\mathrm{Ga}-\mathrm{Gn}}{\mathrm{a}}$

In this case: $\mathrm{Cut}=\mathrm{I} 33+\frac{\mathrm{I} 6000-15000}{50}=\mathrm{I} 53 \mathrm{ft}$. per acre, or I 53 million $\mathrm{ft}$. all told.

Denominator a is made only fifty years because there is no large gap in age classes here as in the Lodge Pole case cited before, and fifty years seemed quite sufficient to spread the small surplus, especially in view of the fact that a considerable amount of large select stuff is rapidly becoming spike top and "going back."

6. Modified Fixed Yearly Cut. Since it appears desirable to cut on selection plan and cut the property over as rapidly as possible to avoid loss of large, old stuff, the attempt is made to cut over in twenty-five years, or abont 40,000 acres per year.

Taking not over $30 \%$ of total, about $4.5 \mathrm{M}$. ft. per acre the cut per year is: 4.5 M. $\times 40,000=180$ million ft. Fere, as in the

* Calculation of growth and growing stock in feet board measure always involves a certain apparent fallacy. In speaking of the average growth of ripe timber per acre, the stand Io, or 20 years old is also included, though, of course, there is no material here as yet to make any sawed stuff of any kind. 
Lodge Pole case, it is not possible to plan the fixed yearly cut for the whole twenty-five year period. Selection of areas and order of their cutting are determined by the purchasers, more than by the forester. But the plan is now clear, the forester knows that he should make efforts to bring up the cut to 40,000 acres per year, cut on selection plan, take about a third of the stuff and sell about 180 million feet. It is a safe plan to follow, it has a basis in the Growing stock and growth of the forest as determined by species and site, and as measured and known.

i. On this property of Western Yellow Pine with its good sites and rapid growth silviculture will probably abandon the Selection Method after the first cutting over. In this case, by that time there should be a complete division of the forest on the ground and a reliable inventory so that Regulation can at once go to a regular Area Allotment. Here again, it is desirable if not necessary, that the large property be divided into several Working Sections, merely by reason of size. A million acre forest will prove unwieldly as soon as the markets make good forestry, in keeping with species and sites, a practical enterprise.

The foregoing will suffice to illustrate what is attempted in Regulation of the cut, how the methods apply, and the good that is accomplished. It is clear that in our large Wild Woods properties it is not a matter of nice accuracy, Regulation can only secure a fairly reasonable figure, safely based on actual conditions of the forest and applicable under present conditions of market and means of transportation.

It is also evident that Regulation is adlapted to the methods of silviculture, that in the beginning with Selection Method, a simple Area Regulation, a Modified Fixed Fearly Cut with Volume check based upon Return and Rotation, and 'calculated by Von Mantel's formula is quite satisfactory. Also that simple Volume Regulation, whether based on Von Mantel or the Austrian Formula, tends to an Area Regulation in time. As stated repeatedly, Regulation of the cut tends toward Area Allotment, full or restricted, as soon as a more intensive silviculture is made possible by a more complete and dependable utilization. In all cases this Regulation of the Cut in Volume performs only one part of Regulation and does not replace Division of the Forest and proper distribution of Age Classes. 


\section{G. GENERAL PLAN OF IMPROVEMENTS.}

In every forest property there is need for roads, trails and telephones, and in many cases for other improvements to make the forest accessible and enable various kinds of work to be done with expedition and economy. It is chiefly Silviculture, Protection, and Utilization which make necessary these improvements and plans for them nust take into consideration these three most important objects. In addition to these greater improvements necessary in the raising and removal of timber, or the principal crop, there is also need of suitable housing of men, of special means to assist in protection, such as look-out stations, stores of supplies and tools; and on many of the large forest properties, both East and West, improvements are needed to facilitate various lines of secondary utilization, such as grazing, utilization of resin, tanbark, seeds, maple sap, etc.

Housing of men, and animals, most of the special provisions for protection and utilization are matters of detail plan and belong more in the sphere of forest administration than that of regulation. In a new country and on very large properties, however, the importance of a general policy concerning improvements is sufficient to necessitate its embodiment in every complete working plan.

a. Roads in all forest properties serve three functions: they make the forest accessible, and enable transportation of material and timber into and out of the forest. They connect different parts of the forest itself and facilitate work, especially protection. They enable general travel through or across the forest. The relative importance of these three functions varies with locality and topography. In the Lakes Region or the South, a forest of one township, located between settlements, makes the function of general travel nearly as important as that of facilitating logging and other work. In parts of the Rockies, Sierra and Cascades, topography determines the location of every important road, and comparatively few roads can serve more than the one purpose of getting in and out of the forest. Between these extremes, many intermediate situations occur.

I. The plan and development of the road-system is usually dominated by utilization, and the removal of timber sets definite 
requirements as to location of road, grade and construction. But in mountain countries a portion of the roads may be free from these requirements, and may serve merely for general travel and to connect different parts of the forest. It is a common thing to locate roads in the Rockies and other mountain districts on top of ridges to insure easier travel, especially less trouble with snow, though, of course, such stretches of road may not be of any use in hauling logs. In new districts, where present methods of logging do not call for ordinary roads, but must resort to special means, railways, slides, chutes, flumes, etc,, and where the expense of regular road construction is great and but little justified as yet, this tendency toward building a system of roads primarily for general travel and accessihility will continue and influence the general plan.

In level and ordinary rolling country the roads should be planned for effective and economic utilization.

2. In the general plan of development of a system of roads in a new district there is a choice of procedure. We may adopt a general policy regarding the rate of development of roads, and general rules for detail location, grade and construction and then build as we need. Or else, we may plan a definite system based on reliable maps, studied in the field, and finally located on a special "road map" as "proposed" road system, to be built as time and money allow, and as necessity arises.

This latter method will prove best. The development of roads piece-meal and haphazard, building wherever there seems need for it, and adding without plan, has cost millions in the old world, where hundreds of miles of highways have been abandoned, and relocated, and it has cost millions in our country, in railway development alone.

That the making of this general plan is important and should fall to competent, experienced men is self evident. Mistakes in this work are costly and in most cases later changes are made reluctantly.

3. 'To plan a road system with a view to serving also in proper division of the forest is adding an unnecessary complication. Division of the forest should and naturally will use the roads as far as convenient, but the roads have their own definite functions and should be built for these and these only.

4 The General Plan for a road system for any given property naturally must depend on conditions of the property itself, and but 
few general principles can be laid down for its development. On a property of Michigan cut over lands with practically nothing to haul, uncertain reproduction and slow growth, the matter of roads may well be deferred. In an Adirondack forest park where money is supplied and where the object is to make the forest accessible for pleasure, a system of good macadam roads is appropriate and advisable; it will pay. In a well timbered property in the South where logging goes per railway, a set of fire lines, merely kept open for accessibility may be all that is necessary for some years. Practically the same applies in a large part of our western mountain forests.

The basis for a road system is profitable use; there must be something to hatl and the road must make hauling more effective and economical. Generally the value of a road system as part of development of a forest property has been underrated. And this is as true of the forests of the old world as of our own country. Thousands of acres of forest in the Tyrol, in the Southern Alps of France are, today, inaccessible and have practically no income. In the Creat Lakes District conditions for years have been such that the putting back on the land of one dollar per acre would have developed a road system, and with it a forest division and protection and closer utilization which would have made these forest properties into wellpaying business enterprises and would have changed the attitude of the people toward them, and resulted in more satisfactory taxation and protection. The same is true in part of the Southern Pinery. Here a rapid growth, easy and cheap logging and proximity to market are sure to develop a most intensive practice with regular thinnings and artificial reproduction. If some of the income in cutting the virgin stand is put back on the land in reproduction and roads, the property is ready for continuous intensive work. Without this development of the roads, there is either long delay in proper income or else a sudden demand for large sums for roads; both unsatisfactory.

The same principles apply everywhere; good site, rapid growtl and fair topography will justify road-development; poor, cold or dry sites, hox eanyons, rockslide and cliff situations for long distances, necessarily hinder. In more remote and difficult situations it is often better to defer building roads and get on with trails. In this case it is of value to locate the trail at once on a wagon road grade, and allow the trail to develop into a road if need be. 
5. In actual location of roads on a forest property topography rules; the loaded wagon or sleigh should not go uphill. Valley and ridge in the mountains, with parallels to cut large slopes, form the chief features here; while in level and rolling country great choice of location exists, and a net work of roads may be suited entirely to the needs of the forest.

The grade is important, the worst piece in the road is a measure of its usefulness. Practicability of using the road for as many days each year as possible, and ease of maintenance are matters for the general plan to consider.

6. Here also should be mentioned the matter of co-operation between the owner of the forest and local authorities, neighboring owners of forest lands, mining companies and other people interested in the highways of the district. 'The possibility of creating favorable public sentiment by means of road-construction is worthy of consideration and liberal treatment.

b. Trails are an improvement required primarily in mountain countries where they replace the road for travel on foot and horse. But with forest division, trails along division lines of lots and sublots, etc., the foot-path or trail is likely to gain importance even in level country. In the case of trails as with roads the preparation of a general plan based on maps deserves preference over the build-asyou-need, haphazard way of developing the system.

As stated before many trails may as well be located on regular wagon road grade and bridge over to the more satisfactory and permanent form of communication.

c. The Telephone in forestry is an innovation; it is just beginning to find its way into the European forest and is much less used there than in the United States. It is helpful in all kinds of work, but is especially needed in fire protection. Like trail and road it costs considerable money to build and costs every year for maintenance through decay of poles, breakage of wire, etc. Being most needed in protection, it is this line of work which dominates the planning of a satisfactory system of lines, and urges their construction, almost regardless of the general development or condition of the property. As with trails and roads, there should be a general plan, in which connection of different parts of the forest (ranger stations) with each other and with headquarters are most important. 
d. Hotses, barns, and pastures needed in the care of the forest property; look-out towers or special improvements for protection, and the building of fences in grazing administration are usually provided as development of the property requires. For this reason the general plan can do little beyond stating the policy to be pursued. Questions here to discuss and answer may be as follows: should permanent headquarters be built, or should men be merely camped in tents, etc.; do the conditions of topography warrant and demand permanent look-out towers with regular man and telephone or is it enough to build trails to certain high points and require the local patrol to visit these? Is the grazing on this property important enough to warrant any improvements and development, or is it to be treated as temporary, and discouraged and discontinued as soon as possible? If grazing is to be permanent and valuable, should pastures, drift fences, corrals, etc., be built and should this be left to stockman or owner of forest? etc.

Most of these improvements for administration and secondary utilization are not expensive, a mistake is not serious, and is readily remedied. Whether a ranger station is placed at the best possible place or not, is not serious, the whole affair only costs a few hundred, and can be replaced anywhere on a month's notice.

\section{H. PLANS OF UTILIZATION.}

Regulation of the Cut merely states the areas to cut and the amount of timber produced on the forest which may be taken from this every year without danger of injury, and does not concern itself with methods of logging or utilization. For this reason a separate plan is necessary.

I. Cutting Timber. In the German forest the cutting of timber in State forests is done by the State itself. The forester makes contracts with individuals or groups, to cut, or cut and skid to the nearby road timber on a given area at a price agreed upon, always per cubic measure. This keeps the logging entirely in the hands of the forester, and he insists on methods which do the least injury. In the United States the ordinary timber owner is also lumberman and logs as well as manufactures. He also has the entire situation in his. 
own hands, to do as he prefers. But there are also a large number of owners who sell timber on the stump. In these cases logger and owner of the forest have entirely different interests; the former wants cheap $\log s$ and refuses to do anything which costs extra money; and the owner would like to have the logging do the least injury to the remaining forest, and asks for considerable extra work and ontlay. This leads to elaborate contracts, necessitates constant supervision and often ends in difficulties. What the development is to be in the United States to remedy this situation is not certain, but in all cases where a reasonably intensive forest management is warranted, sale of stumpage should te avoided, and logs or wood delivered at the road by someone entirely under control of the forest owner.

This introduces necessity of planning and deciding upon general policy, as contract logging, or logging by owner; proper methods of logging, such as machine logging, loging per sleigh haul, all year logging; and logging for particular goods, railroad ties, mine timber, saw logs, cordwood, etc. Thes are matters of great importance and deserve attention in the General Plan. Here also belong considerations of secondary utilization, such as grazing, turpentine, tanbark business, etc.

2. Grazing. Here the General Plan should state clearly opportunity for grazing, the importance of this to owner and community; effect on forest and general methods to follow if grazing is allowed.

In the Hardwood forest of Northern Michigan there is little opportunity and still less demand and grazing need not be considered. In the Southern Pinery there is little and poor feed, great insect pest, poor grazing, but there is considerable demand, and for a time at least, this must be reckoned with. In the Rocky Mountain Districts over half of all large forest properties offer considerable opportunity for grazing and generally demand for this range far exceeds supply. Generally it is true, and yet rather unfortunate that opportunity for grazing in forest properties increases with dry climate and high elevation, the very things which make silviculture and the very existence of the forest difficult.

Since the effect of all grazing is more or less inimical to forest growth, need for a close supervision and careful regulation increases, 
usually, with opportunity for grazing. All kinds of stock injure brush and tree growth, they hurt the small seedling most, trample and tear them out; they browse, on hardwoods more than conifers; they rub, bark, and break all kinds. This damage is overrated by the European forester who has, for centuries, had to fight to keep any forest cover at all in nearly all densely populated portions. The danger is much underrated by the farmer and stockman and by most people in the United States. The damage is greater with close herding as is practiced with sheep, and in general, can be modified very materially by proper methods of handling.

In many of the forest properties of the West, there exist large areas of grass and brush lands which have been in this non-forested condition for centuries and the likelihood is that difficulties of reforestation, slow growth, and remote inaccessible location will tend to keep these areas in such condition for many years more. Here grazing is the only proper use of the lands. In many cases grazing assists the forester by the removal of an inflammable grass cover by keeping interested people scattered over these areas during the danger season, and by tearing up the top soil and trampling in the seed of trees. In these western mountain forests grazing is generally restricted to summer season, average about 100 days, involves mostly sheep and cattle, to a small extent goats and horses, the latter both destructive stock. Capacity of the range varies within wide limits, averages in our western mountains and under present conditions about one head of sheep to four acres of land for the Ioo days, or about twenty-five sheep rations per acre. Five sheep are set equivalent to one head of cattle.

The income from this industry, about $3-5$ cts. per acre and season, is very small, and use of the land for this purpose is advisable only as long as a good forest can not be established or maintained. In planning for the proper method of handling this business several important points arise: the relation of forest owner and local people demands that neighboring stock owners receive preference, that small owners be treated fairly and that each stockman has assurance of his range. Safety of range and forest demand that each man be allotted his own separate range, that he be given the same one for a number of years, so that he becomes interested in the 
maintenance and improvement of this range and can properly be held responsible.

The General Grazing Plan requires at least a preliminary examination of property and usually is based itself on the conditions met with as they have existed for years past. A reliable determination of carrying capacity is difficult, and requires thorough scientific training; all efforts in this direction by the stockman have furnished no results, his practice has led to devastation and general reduction of range capacity.

3. Resin industry, or "Naval Stores Industry". This is restricted in the United States to the Southern Pinery, and primarily to the forests of Longleaf Pine. Practice in the past has been to "tap" or "bleed" for three or four years, usually with the expectation of logging the timber as soon thereafter as possible. A change from the destructive "boxing" to the "cup" method, permits of greater adaptation and a prolonged use of the tree for this purpose.

The future of this industry depends on cost of labor and the value of the resin products, chiefly turpentine, and this in turn on the possibility or probability of development of substitutes for turpentine and rosin. Assuming the value of resin to continue the question for the General Plan is first: should the forester develop special stands of timber with resin as the important product, or shall resin remain merely a biproduct in ordinary forestry? Again, should bleeding be restricted to mature stuff and be continued only for a few years, or should the stands be specially started (wide spacing) and heavily thinned to enable use of part of the thinnings, and also permit of a prolonged use of the mature stand for bleeding, by proper care and rotation?

In regulation, in development of proper age classes and especially in distribution of age classes, or proper mixing of old and young stands over the property and then also in establishment of independent woods or cutting series, the resin industry needs consideration. for stands of timber in process of tapping are in an unsafe condition and a menace to surrounding timber on account of fire as well as insects, notably bark beetles. Regulation should keep each stand in such a condition that, in case of trouble, it may at once be removed and trouble checked with the least danger to the surrounding stands. 
Regulation through proper age classes and a suitable area allotment should provide a continuous supply of resin, in keeping with size and condition of forest. If bleeding takes only the stands and trees to be logged in the near future, Regulation for the Resin Industry simply runs four years ahead of that of the cut. But in this case a definite area regulation becomes necessary, stands to be tapped must be picked out at least five years before logging, bled for four years and then turned over to logging. An area allotment for ten years, revised every five years will answer very well; to prepare for long periods ahead is neither necessary nor advisable, since uncertainties in the resin industry, dangers from fire, insect and windfall are very great. If the Selection Method is used, area allotment takes on the form of modified fixed yearly cut as outlined above, and tapping is restricted to trees to be marked for cutting. For this reason resin work should be preceded by a regular marking, which will avoid confusion when the trees are to be boxed or gotten ready for cup and gutter.

As regards the method of utilization of resin, the conditions resemble those met in timber cutting; it may be done by the owner through day labor or contract, or else it may be sold on the stump. Experience would indicate that this latter in the resin industry is even less satisfactory and more dangerous to the forest than is the selling of timber on the stump.

4. Tan Bark and tan extract industry allies itself so closely with the cutting of timber that little additional need be said. In many cases, however, this is not true and the value of this industry may even influence choice of species to raise and method of silviculture to employ.

In Oak coppice the entire plan is often based on harvest of bark, and in Chestnut stands utilization of the timber itself is modified, the wood is ground and tan extract supplies the chief income.

Other secondary forms of utilization of the forest property exist in different localities, and under various circumstances. Ordinarily their importance, income, permanence, etc., determine whether it is necessary to consider them in the Creneral Plan, and the few illustrations cited will indicate their treatment. 


\section{GENERAL PLAN OF PROTECTION.}

Protection against fire and trespass is one of the most important tasks of the forester. As soon as any effort at forestry or even ordinary care of property is attempted, effective fire-protection demands attention. And it must be a protection which protects, and protects all growth, and not one of the "light burning" type, where reproduction and young growth is wilfully destroyed by fire to save a few saw logs, a criminal practice occasionally recommended in our country.*

Protection of the forest against insects, which in the last fifteen years has cost several millions in the United States has always been one of the standing duties of the European forester, and of late even the fight against wood-destroying fungi has been added to his work. But both, insects and fungi, are too irregular in their occurrence, and the methods to combat the evil have not been sufficiently developed to warrant making these lines of protection part of the regular program or Working Plans, and the matter so far has been left to special effort and therefore to special Plans.

Since patrol sufficient for fire protection is usually ample to avoid all serious trespass and vandalism, consideration of forest protection in the General Plan narrows down to measures for fire protection. These considerations involve a study of the property to determine the degree of danger, dangerous areas, stands of timber most deserving protection, climate and fire seasons, sources of fire, human element in this, topography and accessibility from the standpoint of fire protection, the methods best suited, as well as all the available means to prevent and combat the danger, including cooperation of public authorities, neighboring forest owners and the people of the district.

The degree of fire danger varies within wide limits not only for different parts of the country with different climates and forests, but also on the same forest property itself. Dense stands of old timber are most immune, dense stands of sapling conifers 5-20 feet in height are in greatest danger of taking fire and are almost certain

* This practice is old in the Southern Pinery; has always formed part of the protection of Turpentine orchards, and was carried to the Western forests and recommended particularly for the forests of Yellow Pine and Sugar Pine by some of the prominent lumbermen. 
loss and total loss if fire once starts. Cut over lands are fire traps, both in hardwoods and pinery; hardwoods are not as easily destroyed as conifers, but the leaf mulch under hardwoods, in dry years, is often worse than the soil cover in conifers, etc.

Forests in the Lake Region and Canada, and also those of the Rockies have suffered more and are in more serious danger than those of the South. Dry spells in early spring and again in the fall after frost, but particularly the specially dry seasons which recur every 8-12 years in the North and West have made enormous forest fires possible, where literally millions of acres of land were overrun. In mountains, particularly the Rockies and the East side of the Pacific Ranges, the South slope (exposure to South) is dry, brushy or bare and fires start easily; the North slope is well wooded, cool and damp, and much safer. When sufficiently dry, however, it is just these well wooded slopes which make the most terrific fires and involve the greatest money loss, a fact also experienced in stands of giant timber on the coast where usually a wet climate gives the impression of great safety.

In all mountain property, effect of topography must be considered; fire runs rapidly up the slope, it descends slowly, it creates great draft in all narrow valleys, and it is harder to get to and fight, but generally easier to discover in mountains than in flat lands. The temptation is to protect valuable stands and neglect the less valuable. This is commonly a mistake, the fires gain headway in the unprotected woods and then spread irresistibly over the valuable forests in spite of all effort of protection.

Means of fire protection in the forest consist chiefly of : patrol, equipment and outside help. Since the proverbial ounce of prevention is the chief object, Europe has always relied on patrol, together with ample paths and roads to make and keep the woods accessible. In the United States patrol has generally been neglected and even at present there are practically no large forest properties with a patrol in any sense adequate to the task. European experience indicates that an area of over 5000 acres to one man on foot is too large, that genrally not more than 2000-3000 acres should be watched over by one guard.

To make up for lack of help, the foresters in the United States have developed equipment, particularly telephone, and look-out 
stations, etc., and have endeavored to supply with excellent organization what they lack in numbers.

Organization of outside help is necessary since patrol service is never, in any forest, sufficient to fight fires, and is especially needed in their regular work during a time when large fires are burning on parts of the property. This organization usually consists of definite arrangements with stores, etc., for supplies, provisions, tools, and for help; and also involves the arrangement of paid for, or gratis co-operation with the people of the district, by which they agree to watch, prevent and fight fires, whether ordered or not. To serve its purpose, the Plan should outline an organization such that any fire is detected within one hour and is reached not later than within two hours from the time smoke rises above the timber. For some years lack of funds may prevent a full development, but the plan should fully recite conditions and clearly show what is needed, and then make the best distribution of the means at hand.

A common mistake which has been made in forest protection has been an effort to economize and get on with a sort of half protection. In the Great Lakes Region this has been worse than no protection at all, for it has merely led to contempt on one side and discouragement on the other. Ten years of strict protection would have made further protection easy and much less expensive.

\section{K. GENERAL ESTIMATES OF INCOME AND EXPENSE.}

Estimates both of income and expense are usually stated under the different topics dealt with in General Plans of Utilization, Silviculture, etc., and are stated more in detail in Detail Plans. Nevertheless it is of value to bring these together and state in lump sums for the various important items what incomes and expenses may be expected each year for at least a few years in advance, and supply this important information to the owner, as well as a guide to the forester. The figures should be based strictly on what is practical and expected to be done, but there should be, in new enterprises, a few statements foreshadowing what may be expected in the near future, and the desirable, as well as the actual should be indicated. 
In using this general estimate and apportionment it is necessary to avoid too great rigidity, for it is to be expected that all estimates will be modified to suit changed conditions.

With this Estimate of Income and Expenses may well go a plan of organization or personnel necessary in care of the property, and here as in apportionment of funds, there should be a statement explaining what is really needed for best results, as well as a list of men which may actually be employed under present conditions.

From the foregoing it is evident that the General Plan is necessary for any intelligent, business-like work on a large forest property, and that this General Plan or Plans require considerable information for satisfactory basis. From this it follows that different parts of the Plan will differ in value, and that different parts will be worked out and improved more or less independently, but also that their interdependence is so great that a careful correlation is necessary. It is clear, too, that in our new enterprises, where forest administration starts with very little exact information regarding the property, these plans are only tentative at first and require revisions as fast as information is gathered. Experience in the United States shows that, at first, these General Plans need modification every year, and take on the appearance of the Detail Plans to be discussed, and that commonly the line between these two practically disappears. This condition will not continue; as soon as information is ample and reliable, and as fast as conditions of market and transportation take on a more settled form, the General Plans become more and more definite and permanent.

\section{DETAIL PLANS.}

The Detail Plans take up various lines of work on the forest as outlined in the Ceneral Plans, and also various less important tasks, coming up in administration of the property. These plans, usually in tabular form, state exactly what is to be done during the coming year, or few years, enumerating the particular forties to cut, various sales under way, men holding grazing, etc., permits, number of stock of each, etc. These plans then tell the forester what to do now, where to work, and in silviculture, etc., the method to follow. 
These Detail Plans differ from the General Plans; they do not discuss the conditions and reasons for doing, establish no policies, merely outline an orderly execution. The number of Detail Plans is not fixed, it varies with the nature of the property and lines of work in hand, so that it may vary from year to year even on the same property. The following will suggest treatment of the topics in these plans:

\section{Plan of Organization of Help.}

This is a brief tabular statement, practically a list of the various men employed on the forest, their names, date of employment, salary, station, and principal task. Extra help, such as labor in building roads, etc., is not enumerated. The summation presents cost of regular organization.

\section{Detail Plan of Protection.}

Applies only to one particular year. It enumerates: money allowed for protection; name and number of regular men ávailable, number or name of district and area of country which each man covers, extra help for each district, where stationed, for what period employed, and at what salary.

Telephone lines in each district, location of these and connections, look-out stations with special men, connections and district covered; this latter best stated by Protection Plan Map. Number and location of stores or "caches" of tools and other supplies. Name, location, phone number, etc., of persons at stores, farms, etc., with whom arrangements have been made as to supplies, transportation and help; important points of arrangements made. Name and location of persons engaged to assist in paid or unpaid co-operation. A map as part of Plan of Protection, showing topography, roads, and trails, Ranger and Guard stations, look-outs and their effective range; ranches, hamlets and the number of men and teams available at each.

The Detail Plan usually recites these items for the entire forest and also for each protective district. It should also add the important points in instructions so that each person knows what to do, to whom to report, where to call for help. In these instructions the authority to incur expenses should be clearly indicated. 
The above outline patterns after present plans on some of the large Western mountain forests and is far more elaborate than is necessary on a forest property of ordinary size and character.

\section{Detail Plan of Improvement.}

Here, as in protection, tabular statement should be accompanied by an Improvement Map. This should show existing and planned improvement in different colors; it may well show old existing improvements, those built in last five years; those proposed by the General Plan and those suggested for the coming year.

The tabular statement states the apportionment of money, total and sum for each class. It enumerates each project, piece of road or trail, piece of telephone line, house, barn, bridge, line of fence and gives location, dimensions, character and cost. In roads and trails, length, width, quality, estimated cost; in telephone lines, the kind of support, weight of wire, cost of material and of labor, etc.

In case of roads, trails and telephone lines a detail or special map, indicating location of all points of special difficulty, rock, swamp, canyon, bridge, etc., and also specifications for materials should accompany the tabular statement. For houses, barns, etc., a plan and set of specifications with estimate for cost of material and labor should be attached. The following simple suggestion may serve to illustrate:

Detail Plan of Improvements for igi4.

\begin{tabular}{|c|c|c|c|c|c|c|c|}
\hline \multirow[b]{2}{*}{ Kind. } & \multirow{2}{*}{$\begin{array}{l}\text { Pro- } \\
\text { ject } \\
\text { No. }\end{array}$} & \multirow{2}{*}{ Location. } & \multirow{2}{*}{$\begin{array}{l}\text { Dimensions } \\
\text { Length, etc. }\end{array}$} & \multirow[b]{2}{*}{ Description. } & \multicolumn{2}{|c|}{ Estimated } & Cost. \\
\hline & & & & & $\begin{array}{l}\text { Mater- } \\
\text { ial. }\end{array}$ & Labo1 & Total. \\
\hline Road & I & $\begin{array}{l}\text { Extension up } \\
\text { Little Pinery. }\end{array}$ & $2 \mathrm{I} / 2$ miles. & $\begin{array}{c}\text { Ordinary } \\
\text { woods road. }\end{array}$ & $\$ 200$ & $\$ 400$ & $\$ 600$ \\
\hline Trail & 3 & $\begin{array}{l}\text { New trail Law- } \\
\text { son to Tower. }\end{array}$ & 7 miles. & $\begin{array}{l}\text { Cheap, to im- } \\
\text { prove as used }\end{array}$ & $\% 5$ & I75 & 250 \\
\hline Trail & 7 & $\begin{array}{l}\text { Up Tongue } \\
\text { River Canyon. }\end{array}$ & $\begin{array}{l}\text { Repairs } \\
3 \text { miles. }\end{array}$ & $\begin{array}{c}\text { Put in good } \\
\text { shape. }\end{array}$ & 150 & 200 & $35^{0}$ \\
\hline Barn & 2 & $\begin{array}{l}\text { Ranger's House } \\
\text { on Tower. }\end{array}$ & $\begin{array}{l}20 \times 30 \\
\log s .\end{array}$ & New barn. & IOO & 100 & 200 \\
\hline $\begin{array}{l}\text { Tele- } \\
\text { phone }\end{array}$ & 9 & $\begin{array}{l}\text { Connect Ran- } \\
\text { ger House with } \\
\text { saw mill. }\end{array}$ & 3 miles. & $\begin{array}{c}\text { New line on } \\
\text { trees. }\end{array}$ & 50 & 100 & 150 \\
\hline
\end{tabular}




\section{Detail Plan of Utilization of Timber.}

a. In the European Forest where the forester cuts whatever timber is ripe, according to his plan, and harvests his crop exactly as the farmer does, regardless of any buyers or applicants, the Detail Plan is based on the General Plan of Regulating the Cut and commonly takes about the following form.

Detall Plan of Cutring for Years igi4-igi8.

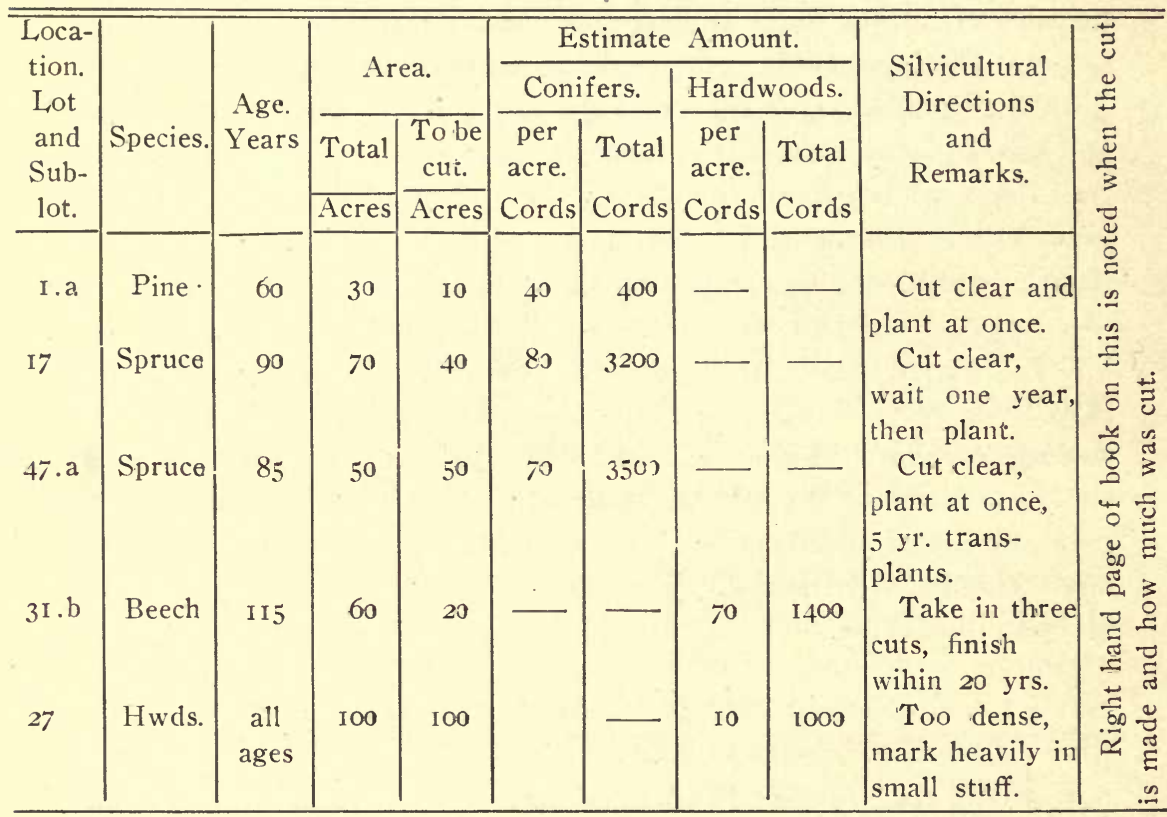

Etc., etc., etc.

A plan, like the above, is made for Thinnings, because in any large forest property it is impossible to keep the hundreds of different stands in one's mind and some of them would surely be overlooked unless the forester keeps a written record.

b. In the United States especially on large remote properties where all utilization of timber must wait until there is application, or market for this timber, the above plan of simply declaring certain areas to be ripe timber and assigning them for cutting during next year, or next five years, needs modification. In these cases the 
detail plan starts with the "timber sale" actually consumated. But in these cases, too, it is almost a necessity to have a convenient record or tabular statement which shows to the forester and owner at any time, the exact status of utilization. This statement takes the place of the above form of detail plan. Where quite a number of sales are in progress, the following form has been found very convenient. It divides the information into three parts:

a. A simple and brief table which serves as the Detail Plan proper.

b. A map or township plat on which the sales are indicated, to go with the above table.

c. A separate table for each sale, to file with the particular sale case, contract, scale records, etc.

The tabular plan (a) gives the following information: number of sale, name and address of purchaser, location of timber, amount of timber, kind and price of timber, date of contract, date when closed, amount of timber cut under this contract and value of timber. Where a sale goes over to another year, the number is kept, and the record shows the cut and income for the year. A new table is prepared each year.

The sheet to go with the sale case itself may well take approximately the old form of the detail plan of cutting. It should enumerate the lots or areas to ke cut, the estimate for each, the method of silviculture, the date (month) when any particular tract is finished and the total cut from this tract.

This plan of cutting in a particular sale can take about the following form:

Sale No. I7.

Name of purchaser: John Doe.

Address: Doeville.

Amount of sales: I 50 million ft. b. $\mathrm{m}$.

Date of contract: Sept. Io, I9 I3.

Life of contract: 15 years.

Silvicultural method, or rules for marking the timber: selection method taking only stuff over $16^{\prime \prime}$ d. b. h., defective or sound; leaving generally $60 \%$ of total volume of the stand, and cutting clear 
only in small spots (not over three acres), exceptions to this in cases of stands of very defective stuff. Where special treatment is indicated for any particular lot, it is so stated. Township...., range....

\begin{tabular}{|c|c|c|c|c|c|c|c|}
\hline \multicolumn{2}{|c|}{ Locality. } & \multirow{2}{*}{$\begin{array}{l}\text { Composition } \\
\& \text { character of } \\
\text { principal stand } \\
\text { an the forty. } \\
\text { Proportion in } \\
\text { tenths. Only } \\
\text { stuff over Ic." }\end{array}$} & \multirow{2}{*}{$\begin{array}{l}\text { Age Condi- } \\
\text { tion of } \\
\text { stands. }\end{array}$} & \multirow{2}{*}{$\begin{array}{c}\text { Estimate } \\
\text { 19I I } \\
\text { all over } \\
\text { I6"d.b.h. } \\
\text { M.ft.b.m. }\end{array}$} & \multirow{2}{*}{$\begin{array}{l}\text { Cut } \\
\text { fin- } \\
\text { ished. }\end{array}$} & \multirow{2}{*}{$\begin{array}{l}\text { Vol. } \\
\text { actu- } \\
\text { ally } \\
\text { cui. } \\
\text { M. ft. } \\
\text { b. m. }\end{array}$} & \multirow{2}{*}{$\begin{array}{l}\text { Actual Mark- } \\
\text { ing recorded } \\
\text { as this work } \\
\text { progresses. }\end{array}$} \\
\hline $\begin{array}{l}\text { Sec- } \\
\text { tion. }\end{array}$ & Forty.* & & & & & & \\
\hline 8 & $\begin{array}{l}\text { N.E. of } \\
\text { S. W. }\end{array}$ & $\begin{array}{l}\text { Yellow Pine 9, } \\
\text { R. F. I. }\end{array}$ & All old. & 750 & $\begin{array}{l}\text { Jan. } \\
\text { I9I } 5\end{array}$ & 980 & $\begin{array}{l}\text { Clear cut with } \\
\text { seed trees, } 5 \\
\text { trees per acre. }\end{array}$ \\
\hline 8 & $\begin{array}{l}\text { N. W. } \\
\text { S. W. }\end{array}$ & $\begin{array}{r}\text { Y. P. 6, R.F. 2, } \\
\text { Bals.I, Ced.I. }\end{array}$ & $\begin{array}{l}\text { Largely old, } \\
\text { much young } \\
\text { Bals. \& Ced. }\end{array}$ & 400 & $\begin{array}{l}\text { Jan. } \\
\text { I9I } 5\end{array}$ & 220 & $\begin{array}{l}\text { Cut takes } 60 \% \\
\text { Y. P. only, } \\
\text { leaves good } \\
\text { cover. }\end{array}$ \\
\hline 9 & $\begin{array}{l}\text { N. W. } \\
\text { N. W. }\end{array}$ & $\begin{array}{l}\text { Y.P. 4, Sug.P.2, } \\
\text { R.F. I Bals. 2, } \\
\text { Ced I. }\end{array}$ & $\begin{array}{l}\text { Y. P. \& S. P. } \\
\text { old. }\end{array}$ & 300 & $\begin{array}{l}\text { Mch. } \\
\text { I9I5 }\end{array}$ & 400 & $\begin{array}{l}\text { Cut all mer. } \\
\text { Y. P. \& S. P., } \\
\text { leaves } 50 \% \text { of } \\
\text { cover. }\end{array}$ \\
\hline 9 & $\begin{array}{l}\text { N. W. } \\
\text { S. W. }\end{array}$ & $\begin{array}{l}\text { Y. P. 9, Bals I, } \\
\text { some pole \& } \\
\text { y. stuff. }\end{array}$ & $\begin{array}{l}\text { Mer. Y. P. } \\
\text { old stuff. }\end{array}$ & 900 & $\begin{array}{l}\text { Mch. } \\
\text { 19I5 }\end{array}$ & 500 & $\begin{array}{l}\text { Marked heavily, } \\
\text { much spike } \\
\text { top, leaves } \\
\text { very open } \\
\text { stand. }\end{array}$ \\
\hline
\end{tabular}

Etc., etc., etc.

It adds materially to the convenience and usefulness of these plans to provide space where the execution of the work may be noted and combine the plan of work with record of execution.

Since these special plans usually develop printed forms for their record, there is great danger, as in all book-keeping, to try to do too many things on the same sheet. In a field sheet this is a virtue, in a plan and in book-keeping it is usually a fault. There is also danger of developing too many plans and records, starting series of records about trivial things. Usually these unnecessary things soon become irksome and are abandoned and much labor and time is wasted.

* In place of the awkward description of : N. E. $1 / 4$ of S. W. $1 / 4$, a simple numbering plan will prove much more convenient and prevent many mistakes. 


\section{Detail Plans of Secondary Utilization.}

Merely for illustration the grazing and resin industries are mentioned.

a. Grazing Plan for the Year. This should be a table showing :

Total number of animals that will be allowed on the property, preferably by the two kinds, cattle and sheep.

Then a list of persons puchasing range, with name, address.

Kind and number of head of stock, district and area assigned, number actually counted in, and money actually received. Time when stock may enter and when it must leave the range may be stated at top of table, if all fare alike, otherwise with each purchaser. Here as in the timber sale, a right hand page with space to record the experience had with the range and stock of each purchaser will easily develop a valuable record for use in future planning.

A map indicating areas assigned to each person or group of persons, and also the driveways for stock into and across the property together with all improvements important in grazing is helpful. This outline applies only to very large properties such as the National Forests. But even on smaller holdings (I0,000 acres) any enterprise like grazing needs regulation and orderly conduct if it is to continue without becoming destructive to the forest. Matters of range study and experiments for betterment are best treated under separate head.

b. Resin Industry. In a forest of Longleaf Pine, under ordinary conditions the Detail Plan of utilizing the resin consists of a list of the lands covered by "turpentine orchards" or under operation, and a map or set of plats presenting the same information graphically. It is convenient to separate areas bled for the first time (new orchards), those bled one, two and three years.

The General Plan should decide on method (box or cup) and number of years any tree is to be tapped and whether the work is to be restricted to a few years preceding the logging of the timber, etc. It also assigns, on this basis, stands fit for bleeding for the next ten years. The detail plan selects and lists the stands to be tapped in about the following manner: 
“Crops" Started I9I4.

\begin{tabular}{|c|c|c|c|c|c|c|c|c|c|}
\hline \multirow{3}{*}{$\begin{array}{l}\text { Crop } \\
\text { No. }\end{array}$} & \multicolumn{2}{|c|}{ Location. } & \multirow{3}{*}{$\begin{array}{l}\text { Area. } \\
\text { Acres. }\end{array}$} & \multirow{3}{*}{$\begin{array}{l}\text { No. of } \\
\text { Boxes }\end{array}$} & \multirow{2}{*}{\multicolumn{4}{|c|}{$\begin{array}{l}\text { Barrels of resin } \\
\text { for years. }\end{array}$}} & \multirow{3}{*}{$\begin{array}{l}\text { Conditions and } \\
\text { experience. }\end{array}$} \\
\hline & \multirow{2}{*}{ Seci. } & \multirow{2}{*}{ Lot. } & & & & & & & \\
\hline & & & & & I & 2 & 3 & 4 & \\
\hline I & 7 & $\begin{array}{l}\text { I } \\
2\end{array}$ & $\begin{array}{l}80 \\
80\end{array}$ & 8000 & & & & & $\begin{array}{l}\text { Dense, small tim- } \\
\text { ber } \therefore \text { small yield }\end{array}$ \\
\hline 2 & 7 & $\begin{array}{l}3 \\
4\end{array}$ & $\begin{array}{l}83 \\
63\end{array}$ & 7300 & & & • & & $\begin{array}{l}\text { Large open timber. } \\
\text { fire destroyed } \\
\text { I50 boxes. }\end{array}$ \\
\hline
\end{tabular}

Since this same sheet is used for all four years of the life of these "crops", it should provide ample space. With the old method of about 200 acres per crop of 10,000 boxes and about 4000 acres for one still, the plans for even a large property (50,000 acres) would not be many. The detail plan keeps the situation clearly before the forester, it shows the execution of the general plan, and furnishes a record of work and results. Where the resin is sold on the stump the matter of detail plans is more complicated, and may well follow the plans suggested under timher sales.

\section{Detail Plan of Planting and Nursery Work.}

This is commonly a plan for several years (5), and in most cases it is convenient to keep separate the planting, nursery work and gathering of seed, if such is done.

a. 'The Planting Plan, whatever the method (seeding or planting) tabulates or lists lands to be covered, the method used, estimated cost and actual cost per acre and total.

b. The Nursery Plan, preferably a yearly affair, states the amount and condition of stock on hand, number of beds to be started and transplants to establish in order to supply the demands set by the forest (for planting, etc.).

It enumerates changes in area, and equipment, if any, and the estimated cost of material and labor for the year.

c. Seed Gathering is not a yearly affair except with very large forest owners (state, national forests). It comes with seed years, (every 3-5 years) and then calls for special efforts and with this for special plans. Usually seed is boinght (in the cone, etc.) from 
individuals and the enterprise merely calls for timely advertisement, instruction, arrangement for receiving and storing and after that, of extracting the seed, cleaning and suitable disposition, shipment, and storage.

\section{Detail Plans of Surveys, and Special Studies.}

On any large forest property, if no more than Io,000 acres, the task of examining lands, estimating and describing stands, studying gowth and habits of the timber on the land, establishing and clearly marking the boundaries of the property, and its divisions is usually the work of a number of years. Much of this work can be planned to come when other work is not pressing and in any case it is desirable that much or all of it be done by the forester in charge, since there is no way in which he gains the necessary familiarity with all parts of his forest in a shorter time or better way. For some years on all forests and for large properties always, there is an annual task in survey work. On large properties this work deserves a place in the general plans, setting forth at what rate the forest should be covered and methods to be used. The detail plan, usually a yearly plan, enumerates the various projects, areas to be estimated and described, lines to be run or re-run, cleared and monumented. and detail studies for volume- and yield-tables to be made during the year. This is put in a tabular form with estimates of cost and a right hand space for record of work actually performed, results including expenses incurred. A map showing the progress of this work forms an important part of this plan.

\section{Plans for Experimental Work.}

On very large properties the owners will often find it to their advantage to allow a reasonable sum to carry on work of an experimental order, rather than to trust altogether to information gathered elsewhere. In state and national forests the reason for such work is evident, and here it receives deserved attention. But there is nothing which needs careful planning, definite control and regular report of results more than experimental work. Plans for such tasks are detailed and special, they develop with demand for the information. The experiments now under way on the National 
forests, for betterment of range, study of growth under great variety of conditions, etc., will be worth millions to the Nation, but a large part of such experimental work can be done and carried to a satisfactory finish only through strong organization, with well digested plans and policies and with intelligent, watchful supervision.

\section{RECORDS OR BOOKKEEPING.}

There are probably few kinds of relatively simple business where a systematic record is more necessary than it is in the care of a forest property. A $\mathrm{IOO}$ acre stand of timber is quite a property in itself and yet in a forest even as small as the usual German revier, i. e., one of about I0,000 acres, it is only I \% of the total and may be a rather remote and very much hidden $\mathrm{I} \%$ at that. In a large forest such as a National Forest, or the State Forest of New York or Pennsylvania, it forms often not more than $1 / 50$ of one per cent, it is one stand in 5000 ; the forester may be in charge of this property for twenty years and never really see it, to go over it and appreciate its condition. The stand of timber, growth, thrift or lack of it, the work done, or needed, even a timber cut ; any accidents, etc., etc., all may have been known and reported by the assistants at one time and another, but unless there is a systematic record kept, all these are forgotten, filed away and never seen again.

This stand may be mature and need cutting, but unless there is proper record and plan, it may remain uncut for thirty years, and entail great loss to the owner. That such things not only can but do happen, was brought out only a few years ago in the controversies in the legislature of Bavaria where is was shown that millions of feet of timber were left to stand unused, long after reaching proper maturity, simply by some process of neglect, where the responsible office practically forgot their existence and condition.

The fact that a good working plan was made, many years ago, does not help this situation; a plan in itself does nothing, it takes systematic execution of this plan and in this execution an orderly record is a necessity. 
The record or book-keeping in a forest business covers three parts :

\section{Property.}

Work.

Results.

\section{a. Record of the Property.}

On every forest property this involves the following items, to which, in some cases, others may be added.

I. List of Lands. In Districts of the United States Public I ands Survey the forty acre lot forms a unit, the forties are arranged by sections, township and range. The list not only gives the number or designation but also the actual area either by the United States records or, if corrected, by last accurate survey, since not all forties are forty acre lots. To this may be added whatever other information seems desirable; a note as to date of last survey is useful, last inspection of lines and monuments, and condition of these.

In the older States withont regular United States survey and then also in mountains, where the forester makes his own subdivision, the forty is replaced by the lot, an area of regular or irregular shape and size, and these lots grouped into blocks to correspond to the sections in regular survey, and therefore preferably not over 2000 acres in size. Civic township and county and even state may need to be noted.

This List of Lands is accompanied by plats based on the original survey; or by a simple "Land Map" showing only areas, lines, their direction and length.

2. List of Houses, barns, cabins, camps, mills (small ones, if part of property), also fences, etc., with brief description, condition and present value. This list is accompanied by a copy of the improvement map.

3. List of Personal Property, teams, tools, etc. A simple enumeration giving condition and value.

4. List of Roads, trails, telephone lines; name or number of each, location (best shown on map, but also stated here), kind, 
length, conditions, and present value per mile and total. This also is accompanied by an improvement map, or by special road and trail map.

The above four lists are corrected to date once every year.

5. Detail Report, or Detail Description of the forest by lots; with maps. Each lot receives at least two sheets, more if needed. On one of these sheets is recorded the full description of the lot, the land and stand, with estimates, etc., in the way that it is recorded in the field, i. e., same topics, same number of columns. On the other sheet is recorded any work, expense and income in connection with this lot, such as planting, thinning, etc., also every cut of timber, the amount and value taken, and in this way an accurate history of each lot is established and maintained. Every log cut should be scaled as coming from its lot, and the totals of the scale report should be recorded on this lot sheet. If any part of the lot is planted, seeded, or fail parts of a plantation corrected, the year, the area, method, cost per acre, and total and the success (end of year or two years) is noted.

This record, on a large property, comprises hundreds of sheets, and is arranged by sections or blocks, and townships, for convenient use.

The description part of this record in an older forest property is revised once every ten or twenty years; in new enterprises it is corrected as opportunity offers; some of this is done every year. But in any case a complete working over of the property should occur at certain regular times, not over twenty years apart. When that is done, the old sheets are kept, and new ones added.

6. The General Report of the Property. This compilation, explained at length before, is filed separately for convenient use. I ike the detail description, it is re-written at set times, but in new enterprises, it is modified, chiefly enlarged, every year.

The manner of filing these documents is a mechanical affair and is done to suit. Filing flat, with sheets standing in Manila folders is certainly as convenient as any way and in small enterprises the equipment for such a file need not be elaborate. Since the gathering of all information here enumerated, especially the detail description of the forest. costs a great deal of money, these documents should he copied and safe storage provided. 


\section{b. Record of the Work and Results.}

This record should accomplish the following:

I. The forester should know every day what work is being done on his forest, and this information should be on paper as well as in his head.

2. He should be able to report at set times, preferably once a month :

What work has been accomplished.

What expense has been incurred. income.

How much material has been disposed of and what was the

3. The record should be brought up every month and be in such a form that the owner, inspector or any other interested person could see at any time, and without calculation, what was done during the past month, or months.

4. Records should show that the policy, general and detail plans under which the forester works, are actually and faithfully being followed.

This record of work to do and work done includes:

I. General Plans, as above outlined. These are revised at regular intervals (ten or twenty years) and on new properties, are amplified every year.

2. Detailed Plans, as outlined and discussed. These are revised every year. As stated above, in most detail plans, such as improvements, planting, utilization, there is space left at the right for the record of the work and results actually accomplished, indicating to what extent the plan has been followed and its projects completed.

3. Daily Record. This is a journal of work with estimated expenses, it states each day what the different men are doing, what projects are under way, the number of men on each, and probable expense. This daily record may also include any important observations, meeting of men, important conversations, etc., although as a rule these observations, etc., are better kept in a small private pocketbook-diary, since it is not always desirable to have them open for inspection. 
4. Monthly Records. A sheet is prepared for each important line of work and arranged in such manner that the work done and expense incurred during any one month can readily be added. The following will illustrate what may be done here; the information is usually not from the above diary, but from the time book and records of the men in charge of the various projects:

IMPROVEMENT WORK I9I4.

\begin{tabular}{|c|c|c|c|c|c|c|c|c|c|}
\hline \multirow{3}{*}{$\begin{array}{c}\text { Projects } \\
\text { as per } \\
\text { detail } \\
\text { plan. }\end{array}$} & \multicolumn{4}{|c|}{ June. } & \multicolumn{4}{|c|}{ July } & \multirow{3}{*}{ Remarks } \\
\hline & \multicolumn{2}{|c|}{ Labor } & \multirow{2}{*}{\begin{tabular}{|c|} 
Mate- \\
rial \\
incl. \\
board \\
$\$$ \\
\end{tabular}} & \multirow{2}{*}{$\begin{array}{l}\text { Work } \\
\text { done. }\end{array}$} & \multicolumn{2}{|c|}{ Labor } & \multirow{2}{*}{$\begin{array}{c}\text { Mate- } \\
\text { rial } \\
\text { incl. } \\
\text { board } \\
\$ \\
\end{array}$} & \multirow{2}{*}{$\begin{array}{l}\text { Work } \\
\text { done. }\end{array}$} & \\
\hline & days. & $\$$ & & & days. & $\$$ & & & \\
\hline $\begin{array}{l}\text { No. 3. New } \\
\text { road, } 3 \mathrm{mls} \text {. }\end{array}$ & I60 & 350 & 250 & $1.4 \mathrm{~m}$. & 165 & 370 & $28 I$ & $\begin{array}{c}\text { 1. } 6 \mathrm{~m} . \\
\text { Fin. }\end{array}$ & \\
\hline $\begin{array}{l}\text { No. \%. Cabin } \\
\text { and barn. }\end{array}$ & & & & & I80 & 400 & 600 & $\begin{array}{l}\text { hse. } \\
\text { and }\end{array}$ & \\
\hline $\begin{array}{l}\text { No. I2. Tele- } \\
\text { phone, } 3 \text { mls. }\end{array}$ & 50 & I IO & 200 & $5 \mathrm{mls}$. & & & & barn & \\
\hline $\begin{array}{l}\text { No. 22. I5 } \\
\text { mls. of trail. }\end{array}$ & & & & & 300 & 600 & 250 & $15 \mathrm{mls}$ & \\
\hline
\end{tabular}

Protection work is best recorded on two separate sheets, the one enumerating labor, material and expense for each month, the other a list of the accidents and their damage.

RECORDS OF ACCIDENTS, FIRES, ETC., For I9I4.

\begin{tabular}{|c|c|c|c|c|c|c|c|c|c|c|c|}
\hline \multirow{3}{*}{$\begin{array}{c}\text { No. } \\
\text { of } \\
\text { case. }\end{array}$} & \multirow{3}{*}{ Date. } & \multirow{3}{*}{$\begin{array}{l}\text { Loca- } \\
\text { tion. }\end{array}$} & \multicolumn{2}{|c|}{$\begin{array}{c}\text { Nature of } \\
\text { damage. }\end{array}$} & \multirow{3}{*}{$\begin{array}{l}\text { Esti- } \\
\text { mated } \\
\text { area } \\
\text { cov. } \\
\text { acres }\end{array}$} & \multirow{3}{*}{$\begin{array}{c}\text { Esti- } \\
\text { mated } \\
\text { dam. } \\
\$\end{array}$} & \multicolumn{3}{|c|}{ Extra cost. } & \multirow{3}{*}{ Cause. } & \multirow{3}{*}{$\begin{array}{c}\text { Disposition } \\
\text { of case. }\end{array}$} \\
\hline & & & \multirow{2}{*}{$\begin{array}{l}\text { Fire } \\
\text { of } \\
\text { class }\end{array}$} & \multirow{2}{*}{ other } & & & \multicolumn{2}{|c|}{ Labor. } & Mat. & & \\
\hline & & & & & & & days. & $\$$ & $\$$ & & \\
\hline I & $\begin{array}{c}\text { April } \\
2\end{array}$ & $\begin{array}{l}\text { Sect. } 7 \\
\text { T 2I N } \\
R_{3} \text { W }\end{array}$ & a & $\longrightarrow$ & 2 & I5 & & - & & Unknown & \\
\hline 2 & $\begin{array}{c}\text { May } \\
-5\end{array}$ & $\begin{array}{l}\text { Sect. } 9 \\
\text { T 2I N } \\
R_{3} \mathrm{~W}\end{array}$ & $\ldots$ & $\begin{array}{c}\text { Tres- } \\
\text { pass } \\
\text { in } \\
\text { tim. }\end{array}$ & 20 & 25 & & - & & $\begin{array}{l}\text { J. Roe } \\
\text { cut ties }\end{array}$ & $\begin{array}{l}\text { Trespassser } \\
\text { paid double } \\
\text { damage. }\end{array}$ \\
\hline 3 & $\begin{array}{c}\text { May } \\
\text { ro }\end{array}$ & $\begin{array}{l}\text { Sect. } \\
\text { T-R }\end{array}$ & c & $\longrightarrow$ & 170 & 500 & 25 & 50 & 20 & $\begin{array}{l}\text { Clear'g } \\
\text { fires. }\end{array}$ & $\begin{array}{l}\text { Reported to } \\
\text { owner recom- } \\
\text { mended prose- } \\
\text { cution. }\end{array}$ \\
\hline
\end{tabular}


Protection WORK FOR I9I4.

\begin{tabular}{|c|c|c|c|c|c|c|c|c|c|c|}
\hline & \multicolumn{3}{|c|}{ March. } & \multicolumn{3}{|c|}{ April. } & \multicolumn{3}{|c|}{ May } & \multirow{3}{*}{ Remarks } \\
\hline & \multicolumn{2}{|c|}{ Labor } & \multirow{2}{*}{$\frac{\text { Mat. }}{\$}$} & \multicolumn{2}{|c|}{ Labor } & \multirow{2}{*}{$\frac{\text { Mat. }}{\$}$} & \multicolumn{2}{|c|}{ Labor } & \multirow{2}{*}{$\frac{\text { Mat. }}{\$}$} & \\
\hline & days. & $\$$ & & days. & $\$$ & & days. & $\$$ & & \\
\hline J. Doe & 12 & 24 & - & 25 & 50 & - & 30 & 60 & - & \\
\hline R. Doe & 7 & I4 & - & 25 & 50 & 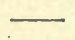 & 30 & 60 & - & \\
\hline Ex. men & - & $\longrightarrow$ & - & Io & 20 & - & 80 & I60 & 40 & \\
\hline Teams & $\longrightarrow$ & $\longrightarrow$ & $\longrightarrow$ & $\longrightarrow$ & $\longrightarrow$ & $\longrightarrow$ & 4. & 20 & 5 & \\
\hline
\end{tabular}

Work in Planting and Seading, igi4.

\begin{tabular}{|c|c|c|c|c|c|c|c|c|c|}
\hline \multirow{2}{*}{ Lot. } & \multirow{2}{*}{$\begin{array}{l}\text { Area. } \\
\text { Acres. }\end{array}$} & \multirow{2}{*}{$\begin{array}{c}\text { Condition } \\
\text { of land. }\end{array}$} & \multirow{2}{*}{$\begin{array}{l}\text { Plan } \\
\text { says. }\end{array}$} & \multicolumn{2}{|c|}{ April. } & \multicolumn{2}{|c|}{ May. } & \multirow{2}{*}{$\begin{array}{l}\text { Success } \\
\text { and } \\
\text { date. }\end{array}$} & \multirow{2}{*}{ Remarks. } \\
\hline & & & & Acres. & $\$$ & Acres. & $\$$ & & \\
\hline 19 & IOO & $\begin{array}{l}\text { Rough, burn, } \\
\text { much dead } \\
\text { stuff. N. sl. } \\
40^{\circ} \text {. }\end{array}$ & $\begin{array}{l}\text { New plantation } \\
500 \text { Tp. per } \\
\text { acre, Spruce. }\end{array}$ & & & 100 & 1200 & $\begin{array}{l}\text { May, I9I } 5, \\
80 \% \text { good }\end{array}$ & $\begin{array}{c}\text { Dry summer, } \\
\text { I9I } 4\end{array}$ \\
\hline 72 & 60 & $\begin{array}{l}\text { Dry, even S. } \\
\text { slope little } \\
\text { brush. }\end{array}$ & $\begin{array}{l}\text { New plt. rooo, } \\
\text { W. Yel. P. } \\
\text { acre, } 2 \text { y. seedl. }\end{array}$ & 20 & 140 & 40 & 250 & $\begin{array}{c}\text { May, I9i5, } \\
70 \% \text { alive }\end{array}$ & Bad site. \\
\hline
\end{tabular}

Work in Timber Sales, I9I4.

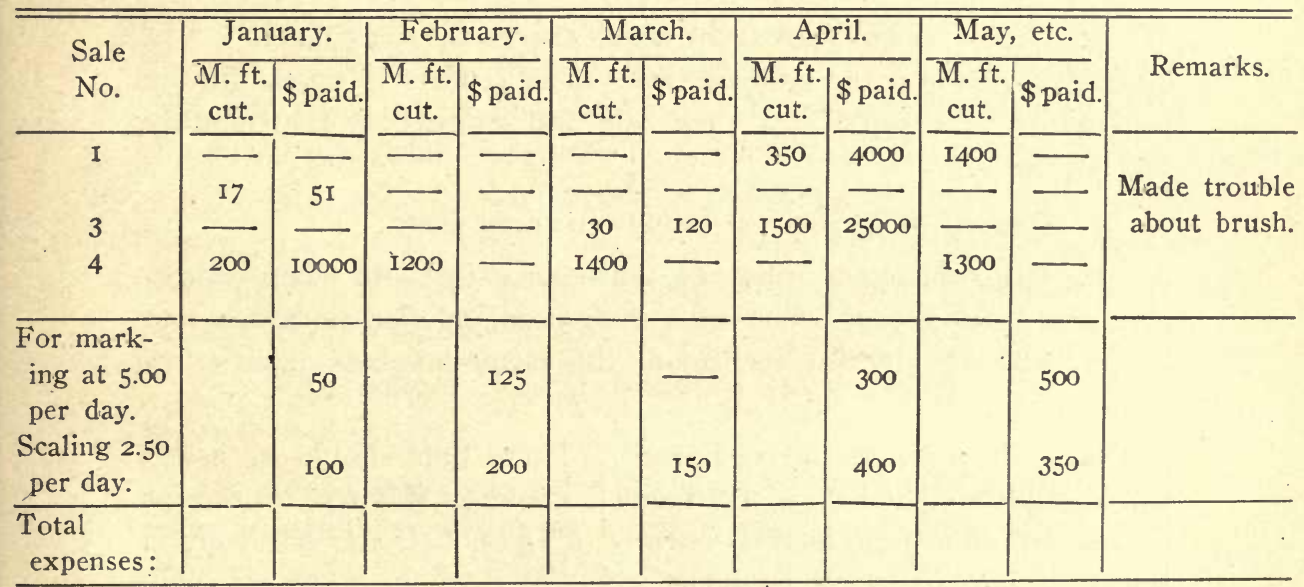

In some cases it may be desirable to prorate the expenses of marking, scaling and other expenses connected with the timber sales.

These monthly records are accompanied by records or corrections made on the improvement map, timber sale plats, etc., where 
the progress of work is indicated whenever there is enough finislied to justify this graphical record.

They should be kept for a number of years, for use in preparation or revision of future plans.

5. As stated under reords of the property, (the detail description of the forest) any work that affects the land or the stand of any lot is also recorded on the lot sheet. And here also should be recorded any cases of special and important injury, fire, insects, snow, windfall, etc.

6. Timber Sales and other Cases of Disposal of Materials. These cases are kept as separate documents, each (in case of timber sales) involving the following:

History of the case, on separate sheet, noting dates of application, contract, etc.

Application and report.

Contract.

Record of scale reports and money receipts.

When timber cutting is going on and scale reports come in each report is entered on:

a. Record of scale reports, kept with sale case.

b. On lot sheet of lot from which the timber was taken.

Once every month the sum of these scale reports is taken off the records of scale reports of each sale and entered on the monthly record sheets.

7. Record of Expenses, usually in three parts :

a. Pay roll, either timebook with space for date when time is given to employee or when time is sent in, or else timebook and ledger, with account for each man; this latter involves much extra work.

b. Bills for material and work. 'These bills should be asked for in duplicates and their treatment is about as follows: on receipt of any bill, it is examined, if correct, it is O. Kd. and one copy is sent to headquarters for payment.

Then the copy retained is recorded on a bill sheet, where it receives a serial number, (a new series each year), and where the following points are noted in different columns: number (serial), name and address of sender, date of bill, material or service fur- 
nished (not in detail, for each bill receives only one line), amount of biil, date when sent to head office, date when paid. All bills are fastened together in the order in which they appear on the bill sheet.

c. Expenses for the different lines of work. Here is brought together once a month the summation of expenses under protection, planting, utilization, improvement, etc., each line of work receiving its own column, and added for a monthly total. This compilation is not always accurate, some parts must be estimates, but it should never be omitted.

8. Record of Incomes. These are treated like the expenses, the incomes for wood, grazing, etc., recorded in different columns, and a total derived for each month.

Book-keeping can be done in many ways; the above is merely a suggestion: it is a plan actually used for several years and found convenient and sufficient.

\section{SUPERVISION AND REVISION.}

The best of plans and the best systems of records can not prevent things going by default, through incompetence and neglect. Care of the forest, as stated under records, is especially subject to drift into a slovenly routine, into a condition of neglect, where whole stands are practically forgotten with great money loss to the owner.

For this reason all experienced forest owners have established two remedies: supervision, usually through regular report and inspection, and revision, or the orderly working over of the property and bringing to date of all information and plans.

I. Supervision. For an ordinary forest property the following may well be done:

a. Each ranger and other assistant working by himself should make a monthly report to the forester, based on a diary, in which he notes each day his work and experience.

b. The forester should report every month to the owner, or head office. This report is based on his monthly record, together with the monthly reports of rangers and also his own personal observations and experience. It should be brief. 
c. The forester makes a yearly report which he submits to head office together with his yearly or detail plans. This report gives the yearly totals as gleaned from the records, i. e., totals by the different lines of work, and grand total of expenses and income. It also recites all important experience and observation of the year, which has bearing on his work, and particularly on the plans he submits.

d. The owner or his representative, on large properties (state, national, etc.) a special inspector should regularly visit the forester, examine his records and at least a few important points in his woods. If he is a regular inspector he should keep in mind that his business is not to find fault, but to help to promote confidence, and harmony, to keep the work at highest efficiency and assure the forest owner greatest possible success. If then he finds that a forester is unable (or unwilling) to do his task, he should report facts, important, provable facts and not merely opinions prompted by prejudice either favorable or otherwise.

To leave a forester without this inspection, without visit from, and personal contact with the owner or his representative, is never safe and is not even fair to an employee working under the conditions under which all foresters must work. In this connection it may be well to state that the usual effort of control by "red tape", as it is commonly invented by the book-keeping division of large enterprises, is never really a control, it is mere hindrance. There is nothing so conducive and nothing so protective to the development of bad and even crooked work as is an over abundance of red tape. The exposure of years of fraudulent conduct in some of our banks and railway systems, the most generous concerns in this line of would-be control, are ample proof.

The forester is a busy man; he is, or should be out in the weather most of his time and it is wise to keep all matters of bookkeeping and reports and correspondence in the simplest, most serviceable form.

2. Revision. As stated repeatedly, the conditions on a forest property are extremely complex, they are constantly changing, not a month, or even a week passes on a large property but what some trees are destroyed, others injured, often thousands of feet of timber falling in a single storm. A heavy snow, or an ice storm breaks 
down millions of twigs and branches, hundreds of trees. Each season brings its growth and adds thousands of cords of wood, and allows insect and fungus to multiply and destroy. 'To keep properly informed, plan and work intelligently with such an enormous crop, it is not sufficient to make an examination this year, prepare a plan and expect to follow it indefinitely. A single, intelligent cutting over of a hardwood property in Northern Michigan would change the conditions of reproduction, composition, growth, and decay so that the forest would hardly resemble the old wild woods, and what seemed true and advisable before, would no longer be so after a twenty year period. These facts have been recognized for centuries, and as soon as income from the forest permitted a proper care, these facts were emphasized and the care of the forest shaped in keeping with their importance. "A proper division, orderly sequence in cutting, and frequent revision of the plan, are far more important than a mere calculation of the permissible amount of timber to cut" is a statement of Cotta, and practically repeated by the best authorities of the last fifty years. In Europe, with orderly, well established forest business the revision comes every ten or twenty years.* This revision examines the property in all its parts, and re-writes detail and general report, and prepares a new set of general plans as well as detail plans.

In our country, in new wild wood enterprises, there is need for more. Diligent effort should be made to increase amount and accuracy of the information, and this should be utilized, records of information amplified and corrected, and the plans, both general and detail, corrected and modified in keeping with this added knowledge.

But beyond this, there should be set a definite period, when a systematic examination is made, whether in one year or several, the whole body of information worked over and corrected, and the general plans entirely re-written.

3. Who should make the plan? In German State Forests this work, (in the past) has been done by a special office which revised the plans of one forest or revier after another and aimed to get around to all of them once every ten or twenty years. The suppo-

* The so-called "Zwischen revision" or intermediate revision is not here considered. 
sition was that "practice makes perfect" here as elsewhere. It has had three drawbacks:

a. The forester works under, executes and is responsible for the results of a plan which he does not make, merely criticizes and usually has to accept.

b. The upper office insists on the plan, for it regards the plan as more competent than the forester who did not make it.

c. The competent, more experienced men in this office do not go through the woods, but leave it to young men fresh from school to describe and judge, very important points.

The controversy is still on, but the Prussian State Forest office in its latest instructions places the task in the hands of the forester, the man who knows (or should know) his forest best; who has to execute the plans and is responsible for results.

In our country it will be the forester in all ordinary, private enterprises. In the state and national forests the task will probably be a divided one for many years. And certainly a number of the more weighty questions, such as proper rotation, total permissible cut from a forest, division into working sections, etc., should have the combined judgment of several men. The example of Bavaria in establishing a special commission to work out proper rotations for different state forests, is interesting in this connection. 


\section{APPENDIX.}

\section{TREATMENT OF REGULATION}

\section{By a Few of the Foremost German Authorities.}

To the student of any subject, the literature, and history of that subject are of value. In Forestry it is German literature which ranks first in quality and volume. Unfortunately German is a difficult language, and experience has shown that most of our students do not acquire sufficient knowledge of German to make use of the works of the leading authorities. For this reason it may be of interest to reproduce here a brief review of the treatment of the subject of regulation as indicated in the table of contents of which a free translation follows:

\section{JUDEICH “FORSTEINRICHTUNG."}

\section{Publ. P. Parey, Berlin; Gth ed. 544 p., I904.}

Prof. Dr. Friederich Judeich, a pupil of Cotta and Cotta's successor as the leader of forestry affairs in Saxony; Director of the Forest Academy at Tharandt, has been generally recognized as the foremost authority on Forest Regulation in Europe. The first edition of his "Forsteinrichtung" appeared in I87I; the 6th was edited by his pupil Neumeister who succeeded him in his position as Director.

In his introduction the author briefly discusses the Yield, Management for Yearly Cut, and the task of Regulation, defining this as follows: "The object of forest management is the most profitable use of soil or land devoted to raising timber"..... "The task of Regulation is to order in time and place the entire management 
or business of the forest, in such a manner that the object of the management is accomplished, as fully as possible."

A complete list of the literature of Forest Regulation follows, enumerating 229 works :

Book I. General Basis, ("Allgemeine Grundlagen”).

Note.--The author does not bother about our reasons for doing this, or preface with description of forest conditions calling for regulation. All this was done centuries ago.

I. The Fundamental Conditions of the Normal Forest, ("Grundbedingungen d. Normalwaldes").

2. The Growth of Timber, ("Ais der Zuwachslehre"). Includes Volume and Quality growth, and growth in Market Price, the Growth in per cent, and Growth per cent as measure of ripeness of stand. ("Weiserprozent.")

3. Rotation, ("Umtrieb"). Includes discussion of rotation for largest interest on capitals invested.

4. Normal Age Classes, ('Das Normale Alters Klassen verhältniss"). Their relation to the yearly cut ; area occupied by each age class. and the distribution of the age classes in the forest.

5. Normal Growing Stock, ("Normal vorrath"). Importance and Volume, as well as Cost and Expectation Value of G. Goes into a great deal of forest valuation.

6. Relation between Growing Stock and Growth in the Normal Forest.

7. Normal Cut, ("Normaler Hiebssatz"). In area, volume and value; its relation to Growth and Growing Stock in Normal Forest.

8. Working Sections, ("Petriebs Klassen" or "Wirtschafts Klassen").

9. The Actual Forest.

Note-CThe author deals only with the ordinary German forest, and not with wild woods.

Book II. Application, ("Anwendungen").

A. Preitiminary Work (Field Work), ("Vorarbeiten").

I. Survey of Land and Topography.

2. Inventory of Forest, estimating and measuring the timber; study of growth; description of land, soil or site, ("Forstabschätzung"). 
a. Site, ("Standortsverhältnisse").

b. Stand, (Bestandesverhältnisse").

I. Preparation of Volume and Yield tables, ("Vorbereitungs arbeiten").

2. Description of each Stand, ("Bestandsbeschreibung"), including system of treatment, species, density, age, origin, volume growth, value in money of stand and soil, growth per cent in value, (corresponds to Schlich's Detail Description of Compartments) and its relation to the Capital, ("Weiserprozent) ; classification of land by Site Classes; notes on future work.

3. Determination of past Incomes and Expenses.

3. General Conditions and Conditions not of the Property itself. ("Ermittelung d. Allgemeinen und äusseren Forstverhältnisse.") Incl. location, altitude, climate, history of forest itself, incl. markets, prices, former silvicultural system, ownership, contracts, former systems of regulation, accidents (fire, insects, storm, etc.) and dangers to forest. Game and trespass. Present ownership and financial ability of owner.

4. Maps and Documents, ("Karten and Schriften"). Incl.: the Inventory Manual, Tables compiled from Inventory Work, showing for each plot of ground.

Kind and Condition of timber (tables).

Quality of land (site tables).

Area occupied by the different Age Classes (Age Class tables). 'Table showing Cut of former years.

Description of Poundaries.

Note.-The above (No. 3 and 4) corresponds to the general and detail report on the property.

B. Division of Forest, ("Waldeintheilung").

I. Division into Lots (Compartments), ("Abtheilungen"), and Sub-Lots or stands, ("Unterabtheilung oder Bestand"), size and form of lots; their relation to topography, and road system.

2. Cutting Series.

3. Working Sections.

4. Severance Cuttings and Reserves.

C. Rrgutation of CUT, or Determination of Yield (which may be cut). ("Errtragsbestimmung").

Historical Sketch. 
I. Area Methods ("Flächenmethoden").

a. Fixed Yearly Cut or Division into Yearly Cuts (by area), ("Schlageintheilung").

b. Area Allotment, ("Flächenfachwerk").

2. Volume Methods.

a. Volume Allotment, ("Massenfachwerk").

b. Method based on Normal Growing Stock, ("Normalvorratsmethoden"). Austrian and Hundeshagen Methods, and their Modifications.

3. Combined Methods.

a. Area Allotment with Volume as check, ("Combinirtes Fachwerk").

b. Combinations of Allotment Methods with those using Normal Growing Stock as basis.

c. Age Class Methods, or Methods working primarily for Regularity in Age Classes, ("Alters Klassenmethoden”).

I. Saxony practice up to 1860 .

2. ("Bestandswirtschaft"), Method of Regulation by Area, working for Regularity of Age Classes as well as Best Utilization of the Individual Stand of Timber.

4. Regulation for Cut of Equal Value. Wagener's Method.

D. Compilation of the Working Plan, ("Zusammenstellung d. Wirtschafts planes." Usually for ten years. Comprises really three parts, the General Report includes List of Lands, or the Reports on the Property, the General Plan, and the Detail Plans. Judeich does not clearly distinguish these, but arranges as follows:

a. General Description and its bases, ("Allgemeine Beschreibung u. zugehörige Beilagen”).

General Description of forest.

Division of Forest, Regulation of Cut.

Future treatment.

Miscellaneous.

List of Lands.

b. Detail Plans.

i. Plan of Cutting, ("Specieller Hauungs plan"). Table of next ten-year cut; one side of book-what is to be: other side of the hook-what has been done. 
2. Plan of 'Thinning.

3. Plan of Planting.

Continuance and Development of the Working Plan, (Erhaltung und Fortbildung d. Einrichtungswerks").

I. Corrections of Survey, (Records and Maps).

2. Keeping the Records of Management (Bookkeeping), ("Führung d. Wirthschaftsbuchs").

Its six Books or Parts; all in tabular form:

a. Div. A. Record by Lot. (Each lot gets two pages and in this is recorded how much cut, money received; planting, thinning, etc., done on this lot.)

b. Div. B. Record of Cut with Comparison of Estimates, when cut is finished on a lot, or stand, the volume and money results are recorded in this book and compared with estimates made before cutting.

c. Div. C. Yearly Cut ; area, Volume (by few grades, timber, fire wood, etc.), keeping scparate final cut of stand, from thinnings. (Only one (horiz.) line for each year) Each Working Section has its separate page.

d. Div. D. Total Cut for Revier or Forest, or for Working Section for the year is compared with estimates or allotment as per Plan. Each year's Cut gets one page.

e. Record of secondary utilization, ("Nebennutzungen"), Grazing, Turpentine, etc., etc.

f. Div. F. Record of Net Income. All incomes and expenses, net income and financial showing, i. e., what per cent is made on capital.

Tabulary form giving: Area of forest, amount of timber sold, gross income from timber and other sources.

Expenses total and by: Logging, other utilization, Improvements (incl. planting), administration and protection, taxes, miscellaneous.

Net income total and per acre.

Forest Capital total, and by soil and growing stock.

Interest made in Management, in per cent.

Remarks, (explanations of important points, special reasons for large or small income, etc.) 
3. Revisions, ("Revisionen").

a. The ten year Revision, ("Hauptrevisionen").

I. How far was Working Plan followed and reasons for deviations. Examinations of everything done in last ten years and comparison with Plan for the ten years.

2. How far has Plan proven satisfactory regarding: Cut; Thinning; Distribution of Cuts ("Hiebsfolge") ; secondary utilization, and improvements.

3. Preparation of New Plan.

b. The five year Revisions, ("Zwischen revisionen"), little more than a case of Special Detail Inspection.

Appendix: A few pages dealing with Regulation of large properties (State, etc.) and proper personnel to use in Regulation Work.

\section{MARTIN “FORSTEINRICHTUNG."}

Publ. by Springer, Perlin, 3d ed., I9I0; 28 Ip.

Prof. Dr. H. Martin, now at the Forest Academy Tharandt in Saxony, formerly at the Academy of Eberswalde, Prussia, is one of the most traveled, and best known authorities in forestry in Central Europe, not only in matters of Forest Regulation and Statics, but in Silviculture and other branches.

In his introduction he defines Forest Regulation about as follows: "It comprises the measures necessary to conduct an orderly forest management. Its most important task is the preparation of Working. Plans which serve as the basis and guide (Grundlage) of the Management. Regulation forms the most important subject of instruction in the business or management of the forest." He adds : "The most important task of Regulation is to direct the order or progress of the harvest or cut and removal of the several stands of timber." Also: "The most difficult and yet the most important task in the field work (Vorarbeiten) is a suitable division of the forest into permanent lots (Wirtshaftsfiguren)."

Part I. Field Work ("Vorarbeiten f. d. Betriebs pläne").

I. Division of Forest into permanent Lots ("Wirtschaftsfiguren"), land Division or "Ort Abtheilung."

a. Division in level country.

b. Division in hill and mountain country. 
2. Division of Lots into Stands or Sub-lots, ("Bestandes abteilungen").

3. Description of the Land (Site) Location, topography, soil ; Classification of land into Site Classes.

4. Description of Stand.

5. Determinations of Amount of timber, methods of doing; Calculation or Computation.

Part II. Growth and Growing Stock as Foundation of Regulation of Cut.

I. Volume Growth; current and average.

2. Quality Growth, ("Wertzuwachs").

3. Growing Stock, ("Materialvorrat").

Reasons for large or small G. (timber, coppice, etc.). Manner of calculation of Growing Stock, Normal G.

4. Preparation of Yield Tables.

a. Objects and Contents of Yield Tables.

b. Different Kinds of Yield Tables.

c. Method of preparing Tables.

d. Money Yield Tables.

Part III. Preparation of Working Plans ("Aufstellung der Wirtschaftspläne”).

I. Combination of Stands of timber into suitable units for better Management, ("Bildung d. Betriebsverbände").

a. Working Sections.

b. Blocks.

c. Cutting Series, ("Hiebszüge").

2. Rotation. Importance, reasons, methods of calculation, of Net Income; Income per cent as measure of Ripeness; Calculation of Se.

3. Determination of the Amount of timber to Cut each year, ("Abnutzungssatz = Materialetat").

a. Selection of the Stands to cut during next ten years (for final cut and for thinnings).

b. Regulation of Amount of Cut by Allotment Method, ("Fachwerkmethoden").

c. Regulation by Methods using the Volume of G., ("Vorathsmethoden").

4. Compilation of Plans, Documents and Maps. 
Part IV. Control and Continuance of Working Plans ("Kontrolle und Fortführung d. Petriebspläne”).

a. Control through proper Book-keeping, ("Gedenkbuch" and "Wirtschaftsbuch").

b. Revisions, ("Taxations revisionen").

Part V. Regulation in Various States, (refers only to State forests) and includes Regulation in Prussia, Bavaria. Saxony, Baden, Hessen, Grd. Duchy Saxony, AlsaceLoraine, Austria and France.

In the former edition he adds a Review ("Rü.ckblick") which sums up the present situation in a very able manner. Among the points made are these:

I. Methods in actual practice differ to some extent but resemble far more than appears from the Instructions.

2. Most essential points in all alike are:

a. To determine what Stands should be reproduced in the next year, or next ten years.

b. In judging them we must consider the forest as a whole.

c. All agree practically, that the Normal Area Regulation $(\mathrm{A} / \mathrm{r}=$ yearly area to cut $)$ must serve as final.

d. 'This Measure is modified according to the condition of age classes.

e. In this agreement on a Normal A rea to be cut each year $(\mathrm{A} / \mathrm{r})$ the rotation $\mathrm{r}$ is set as a definite, fixed quantity. In practice it must of necessity be a variable, the age at which a stand is actually cut must depend on many things, its growth and condition, market, accidents to other stands, etc.

\section{A. VON GUTTENBERG, "FORSTBETRIEBSEIN- RICHTUNG."}

Publ. by Denticke, Wien and Leipzig, ıดı I ; 2 d ed. ; 393 p.

Contains excellent maps of samples in forest division.

Prof. Dr. Adolf Ritter von Guttenberg of the Imperial Academy for Agriculture (Bodenkultur) is well known as the foremost authority in forestry in Austria; author of Forest Mensuration in Lorey's Handbuch, etc. The book is specially interesting to the 
American student since it draws heavily on the forest conditions of the rough mountain country of Austria and is written in very simple and clear language.

In his Introduction, the author describes the considerations and tasks in Regulation; the peculiarities of forestry as a business; and presents a brief Historic Review and a list of literature. There is no special Definition, but he practically defines Regulation in the opening sentences about as follows:

"Forest Regulation is that part of the Science of Forestry and particularly of Forest management which attempts a well planned Order and Arrangement ("Ordung und Einrichtung") of the entire Management of a forest, and especially the Regulation of the Cut in order to assure the most profitable and continued yield (sustained Yield) or income from the property.".

Part I. Theory ("Theorie").

A. Genferai, Basis, ("Allgemeine Grundlagen").

г. Object of Forest management.

2. Forest for yearly Income, ("Nachhaltigkeit").

3. Income or Yield from the Forest (Vol. and Money), ("Forstertrag").

4. Growth in the Forest, ("Zuwachs").

5. Growth in Value as measure of Ripeness of the Stand, ("Weiserprozent").

6. Rotation.

7. The Normal Forest.

8. The Actual Forest and its change toward the Normal Forest.

B. Methons of Regulation, ("Methoden d. Ertrags bestimmung und Betriebseinrichtung").

I. Division of forest into fixed Yearly Cuts, ("Schlageintheilung").

2. Allotment Methods, ("Fachwerksmethoden") in Area, Volume or both; and also by Values or Money returns.

3. Formula Methods, ("Formelmethoden"), chiefly those using Gn and also Hufnagl's.

4. Judeich's Method of Regulation by Area, for Regular Age Classes and best Use of Individual Stand, ("Bestandswirtschaft").

5. Regulation by Experience figures, ("Ertrags schätzung nach Durchschnitts grössen”). 


\section{Part II. Execution or Application ("Ausführung").}

A. Field Work, or Preiriminary Work, ("Vorarbeiten").

I. Division of Forest into: Working Sections, Cutting Series, Lots and Stands or Sub-Lots (Unterabteilungen) Fine examples (Maps) of Forest Division, (Plate I, p. 208) taken from Forest Maps of existing Reviers, from actual practice.

2. Forest Survey.

3. Description of Forest.

a. Special Studies, ("Allgemeine Vorerhebungen") Site; Yield tables; Grades and Prices, Money Yield tables; Losses in logging.

b. Detail Forest Description proper, by lots, ("Specielle Bestandes aufnahme") Site; Stand; Estimates of Volume and Growth; Determination of ripeness; Notes as to work necessary during the next ten years (refers to work with forest growth, not roads, etc.) Preparation of tables and maps.

c. General Description of Forest: Ownership; Location, Area, and shape of property ; boundaries ; conditions concerning the owner, which affect the management, his business and finances, etc.; Topography; Site, including Soil, Climate; Species and peculiarities; dangers to forest; treatment of forest in the past (history of property) ; Present Condition of forest; Surrounding Population and its influence; matters of market, labor, trespass, dangers; Means of Transportation; secondary uses and incomes from forest (grazing, bark, etc.) ; Labor and present Organization of labor in forest; Organization of Forest Officers.

P. Forest Regutation, the, Working Plan, ("Eigentliche Betriebseinrichtung”).

I. General Plan or Agreement regarding the Principles, (Grundzüge") of the Management.

a. Choice of Silvicultural Methods.

b. Choice of Species.

c. Rotation.

d. Decision as to where to begin and how to proceed with the Cutting of the timber, ("Feststellung d. hiebsfolge").

c. Considerations in matters of reproduction and in the care of the forest.

2. Preparation of the Detail Plans, ("Aufstellung der Betriebs Pläne"). 
a. Plan of Cutting, Determination of the area, or of the volume to cut. This for each form, timber forest with even aged stands, the selection forest, coppice and standard coppice.

b. Plan of Restocking (Planting, etc.).

c. Plan of Secondary Utilization (Grazing, Turpentine, Bark, etc.

C. Bookkfieping, or Ricords of THE, WORK and RESUlts OF THE Managemen' $T$, ("Nachtrags arbeiten und Buchführung ü. d. Betriebsergebnisse").

I. Important notes and corrections regarding changes in land area, markets, errors in maps, location of boundary, i. e., history of property which may be of interest to future regulation or explain particular operations or measures taken by forester. He suggests two books :

"Vormerkbuch," for changes and errors which must receive attention at next revision.

"Gedenkbuch," history of markets, seasons, even visitors. But also all improvement, roads, drainage, phone lines, etc.

2. "Wirtschaftsbuch" or Regular Set of Records.

Uses only four books.

a. Record by Lot.

b. The Cut by lots, or else by Working Section, ("Betriebs Klasse") and Forest by totals.

c. Plantation and Restocking generally and work for the care of growing stock, with costs stated, may be added to book a.

d. Secondary Utilization.

D. Revision (Continuance and Development of Plans), ("Erneuerung u. Fortbildung der Einrichtung").

Appendix, Examples in Regulation.

\section{STOETZER, "FORSTEINRICHTUNG."}

Publ. by Sauerländer, Frankfort, A.M., I908; 2d ed., $35^{2}$ p.

Prof. Dr. H. Stoetzer, Director of the Forest Academy at Eisenach, and Director of Forest Affairs of the Grand Duchy of Saxony, one of the authorities in German forest literature; editor of the last edition of Lorey's "Handbuch", the great Manual of Forestry. 
This book combines Mensuration and Regulation, devoting practically equal amount of space to each.

In the introduction the Author explains the task of Regulation and the Normal Forest, defining Regulation about as follows:

"Forest Regulation attempts to bring and to maintain order in the management of a forest; it regulates particularly the manner and time of cutting the different stands of a forest; it plans to restock the land with new stands of trees; and it determines the amount of timber which may be cut each year without diminishing the Wood Capital or endangering the continuance of such a cut for the future."

He adds: "The provisions of forest regulation are not employed for individual stands of timber, cut at intervals of many years, but apply to forests where a yearly cut of timber is possible and demanded."

The Division of the subject is as follows:

Part I. Preliminary Work ("Vorarbeiten der Forsteinrichtung").

Chiefly a brief treatise of Mensuration, adding a thorough discussion on Division of the Forest, Survey and Maps, and also Forest Description.

Part II. Forest Regulation ("Haupt arbeit der Forsteinrichtung").

I. Decision regarding: Silvicultural Methods, Species, Rotation, and the grouping of the several tracts of woods into Working Sections, ("Betriebverbände, Blöcke").

2. Methods of Forest Regulation ("Methoden der Forsteinrichtung"), classifying them into:

Fixed Yearly Cut ("Schlageintheilung").

Area and Volume Allotments, ("Fachwerksmethoden").

Volume Methods depending on the Growing Stock, ("Formelmethoden").

Regulation by Volume, based on Experience figures, ("Ertragsbestimmung nach Durchschnitserträgen”).

3. Execution of Regulation or Preparation of the Plan, ("Arbeitstheile der Ausführung von Forsteinrichtungen").

a. Timber Forests.

I. Table of Age Classes.

2. Allotment Plan, ("Flächenangriffsplan").

3. Calculation of the Yield or Cut. 
4. Detail Description of all stands (by Working Sections) stating site, stand, and what to do with it.

b. Plan for Selection Forest.

c. Plan for Coppice or Standard Coppice.

4. Other Points in Forest Regulation, ("Sonstige Punkte d. Forsteinrichtung").

a. General Description of Forest.

Includes: Ownership, Area, Location, Markets, Prices, Transportation facilities, Site, including soil, topography, Climate, Timber, Species Types ("Waldformen"), System of treatment, Age classes.

History of forest.

b. General Plan of Management, ("Allgemeine Betriebsordnung”), Including :

I. Objects of Management (for largest returns; largest interest on capital; for public good; for Protective forest, Scenery, Park, etc.).

2. Choice of Species, System of treatment, Arrangement into Working Sections.

3. Rotation.

4. Cut, and Principles followed in Cutting; and a showing to prove that forest is not overcut.

5. Reproduction, artificial or natural, size of cutting areas, and methods of work are to be justified by sufficient reasons.

6. Thinnings and Improvement cutting, reasons for frequency and size of tracts treated.

7. Nursery and Plantation Work, ("Kulturbetriebe").

8. Plan of secondary utilization, ("Betrieb d. Nebennutzungen").

9. Plan of Road Construction.

ro. Forest Protection.

Ir. Income and Expenses; estimates of these.

c. Forest Maps.

d. Organization of personnel for forest regulation; checking the work; its acceptance by proper office.

\section{Part III. Control and Revision of the Plans.}

I. Control of Management.

a. Correction of the Survey work, boundaries, maps, etc. 
b. Detail Record of timber cut and planting done, ("Nachweis d. Betriebsergebnisse (Kontrollbuch").

c. Control of Total Cut, amount cut per year compared with amount set in plan. "Waldangriffs Kontrolle."

d. History of Forest, a record of all important events, calamities, market, experiences in cutting, thinning, planting; improvements, trespass; personnel ; hunting and fishing.

2. Revisions every ten years, ("Haupt revisionen").

a. Gathering data for revision.

b. Tabulated statement covering

I. What was done (cut, etc.) last ten years.

2. What is to be done next ten years.

c. Intermediate or five year Revisions, ("Zwischen revisionen"), Careful Inspection, reports, etc.

\section{WEISE, "LEITFADEN FUR VORLESUNGEN AUS DEM GEBIETE DER ERTRAGSREGELUNG."}

Publ. by Springer, Berlin, I904; 202 p.

Professor and Oberforstmeister W. Weise, for years Director of the Forest Academy Münden (Hanover-Prussia), author of the well known "Waldbau", an excellent practitioner and teacher, and one of Germany's leading men in the development of forestry. The book, as stated in the title is to serve as guide to the students in taking his course in Regulation; it combines Forest Mensuration and Regulation, and is one of the clearest and simplest statements of the subject in the German language. The author treats the subject as follows :

Book I. Determination of Volume in the Forest ("Massenermittelung") including relations of $\mathrm{H}$. D. and Vol. of tree and Stand; Volume and Yield tables. Chiefly Forest Mensuration.

Book II. Growth in the forest ("Der Zuwachs").

I. Volume growth of tree and stand.

2. Quality growth.

3. Growth in market price. 
Book III. Conditions of the Normal Forest with regard to growing stock, growth, and cut, where cut is yearly, and of equal volume and where site is uniform.

a. In timber forest with clear cut and artificial reproduction. In timber forest with natural reproduction.

In timber forest with "Lichtungen" or special thinnings.

b. Shelterwood system.

c. Selection forest.

d. Coppice and standard coppice.

Book IV. Rotation ("Lehre vom Umtrieb").

Physical Rotation.

Rotation for maximum Volume.

The technical Rotation.

Rotation for Largest Rental, or Income.

Rotation for largest Income with existing (irregular) Age Classes.

Rotation for largest Interest on Capitals, i. e., Max. Se.

Rotation for Stand vs. Forest, shows that if we have a forest to deal with we may begin with lower $r$ and work up, to get income and interest earlier.

Book V. Division of Forest to enable Regulation.

Revier, Protective Units, ("Forstschutz bezirk"), "Blöcke", "Petriebs Klassen”, "Hiebszüge."

Jagen or Districts (regular or irregular form), Lots.

Abtheilung (Sub-lots or Stands).

Yearly or Feriodic Cutting Areas for Coppice and for Selection forest, ("Schlageintheilung").

Historic Part of Book, Methods of Regulation.

Book I. Regulation in Timber Forest ("Hochwaldschätzung").

I. Devolopment of Allotment Methods.

a. Beginning stages.

b. The finished Allotment Methods.

c. Allotment with the Computation of Volumes limited to part of a rotation, ("Fachwerk mit eingeschränkter Massenberechnung").

d. Development of the modern method which regulates by Area but works for Regular Age Classes and for best use of the individual stand. ("Entwickelıng d. Pestandeswirtschaft.") 
2. Methods using the Normal Growing Stock as basis of Regulation.

a. Austrian Method.

b. Hundeshagen.

c. Breyman, Karl, Heyer and Baden Methods or Modifications.

Book II. Regulation in Coppice ("Niederwald abschätzung").

Book III. Regulation in Standard Coppice ("Mittelwald Abschätzung”).

Book IV. Regulation in Selection Forest ("Plenterwald Abschätzung”).

\section{WAGNER, "DIE GRUNDLAGEN DER RAUMLICHEN ORDNUNG IM WALDE."}

Published by Laupp, 'Tïibingen, I907.

Dr. C. Wagner, Professor at the University of 'Tübingen and formerly forester at the famous Revier Gaildorf, Württemberg. While this book does not pretend to teach Forest Regulation, it is nevertheless one of the most instructive and suggestive works dealing with the proper division of the forest, arrangement or distribution of young and old (age classes), methods of natural reproduction and particularly proper direction and progress of the cut. 'These matters are all fundamental to forestry, they are not treated adequately in our textbooks on Regulation, seem foreign and academic to us in our Wild Woods work, and so are difficult for the young American forester to learn. 




$$
-
$$




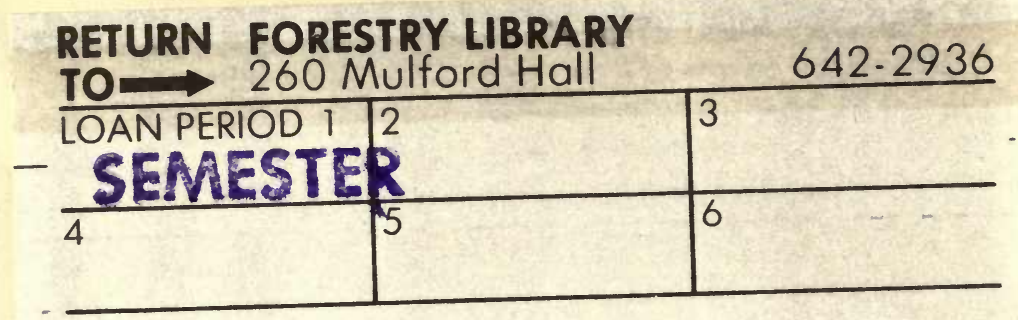

ALL BOOKS MAY BE RECALLED AFTER 7 DAYS

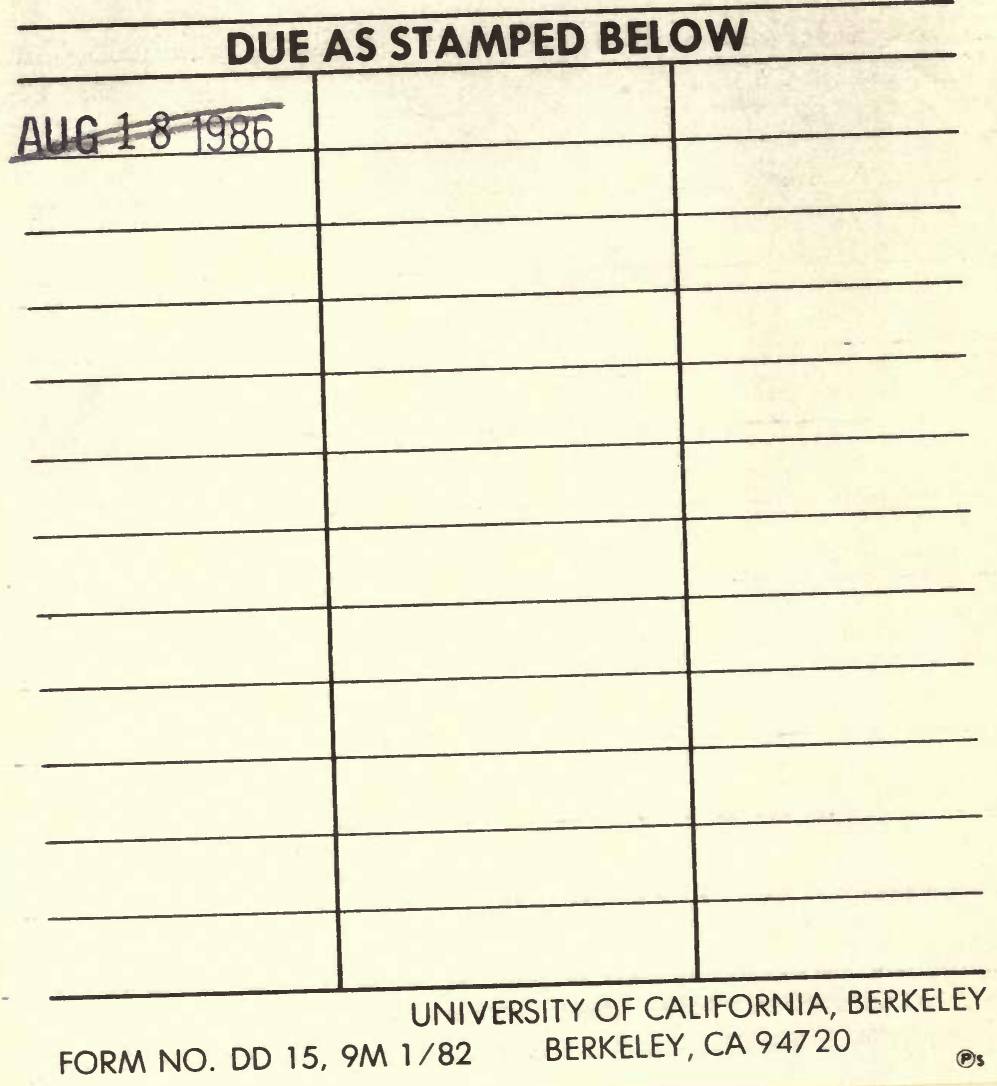




\section{U.C. BERKELEY LIBRARIES}
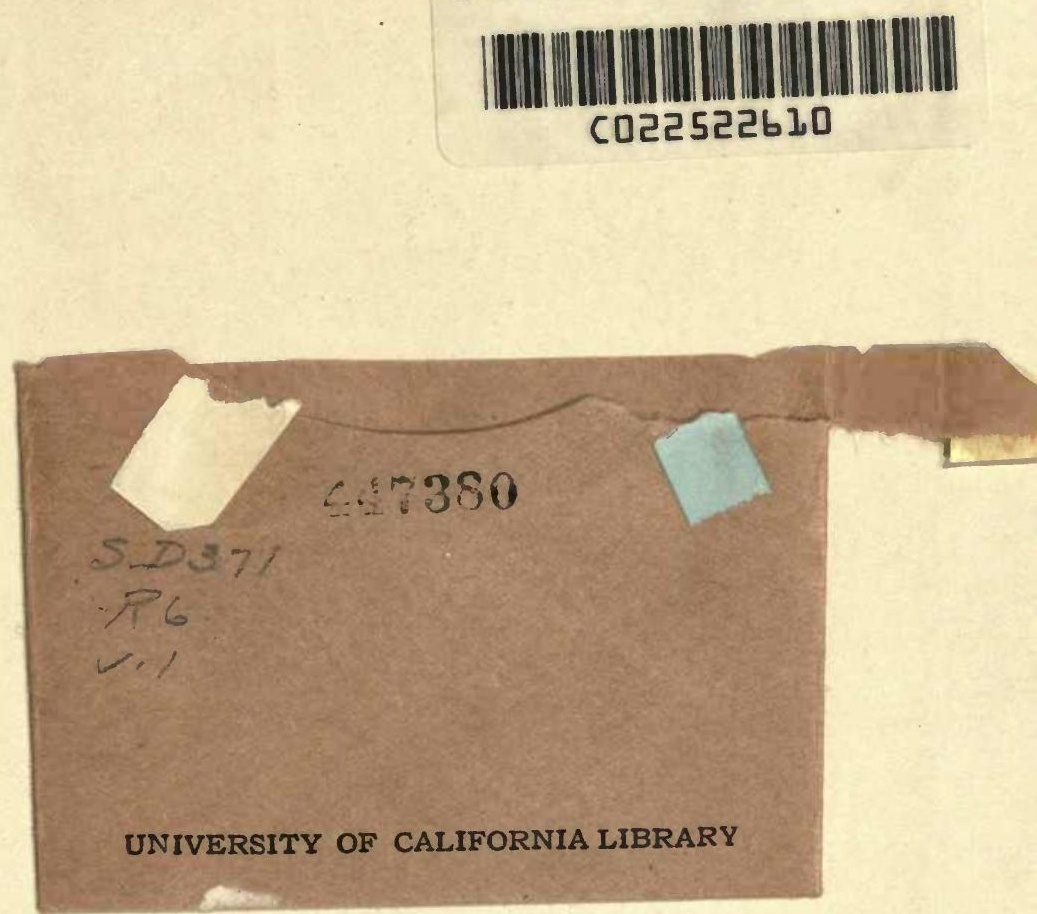
